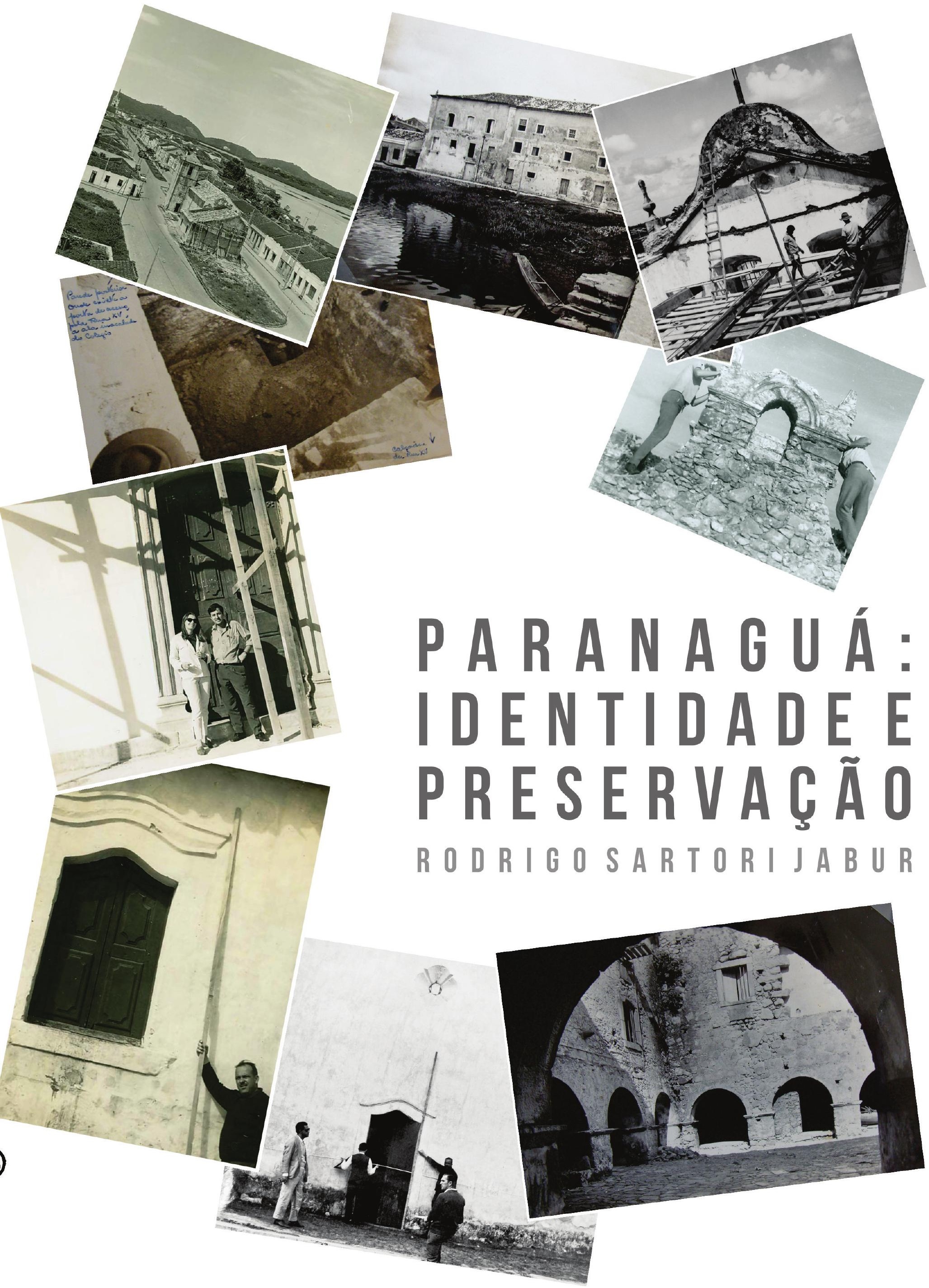





\section{PARANAGUÁ: IDENTIDADE E PRESERVAÇÃO}

Tese apresentada ao Programa de PósGraduação em Arquitetura e Urbanismo do Instituto de Arquitetura e Urbanismo da Universidade de São Paulo, como parte dos requisitos para a obtenção do título de Doutor em Arquitetura e Urbanismo.

Apoio: Fundação de Amparo à Pesquisa do Estado de São Paulo (FAPESP) - Processo 11/08506-5

[versão corrigida]

Orientação: Profa ${ }^{D}{ }^{a}$ Maria Angela Pereira de Castro e Silva Bortolucci 
AUTORIZO A REPRODUÇÃO TOTAL OU PARCIAL DESTE TRABALHO, POR QUALQUER MEIO CONVENCIONAL OU ELETRÔNICO, PARA FINS DE ESTUDO E PESQUISA, DESDE QUE CITADA A FONTE.

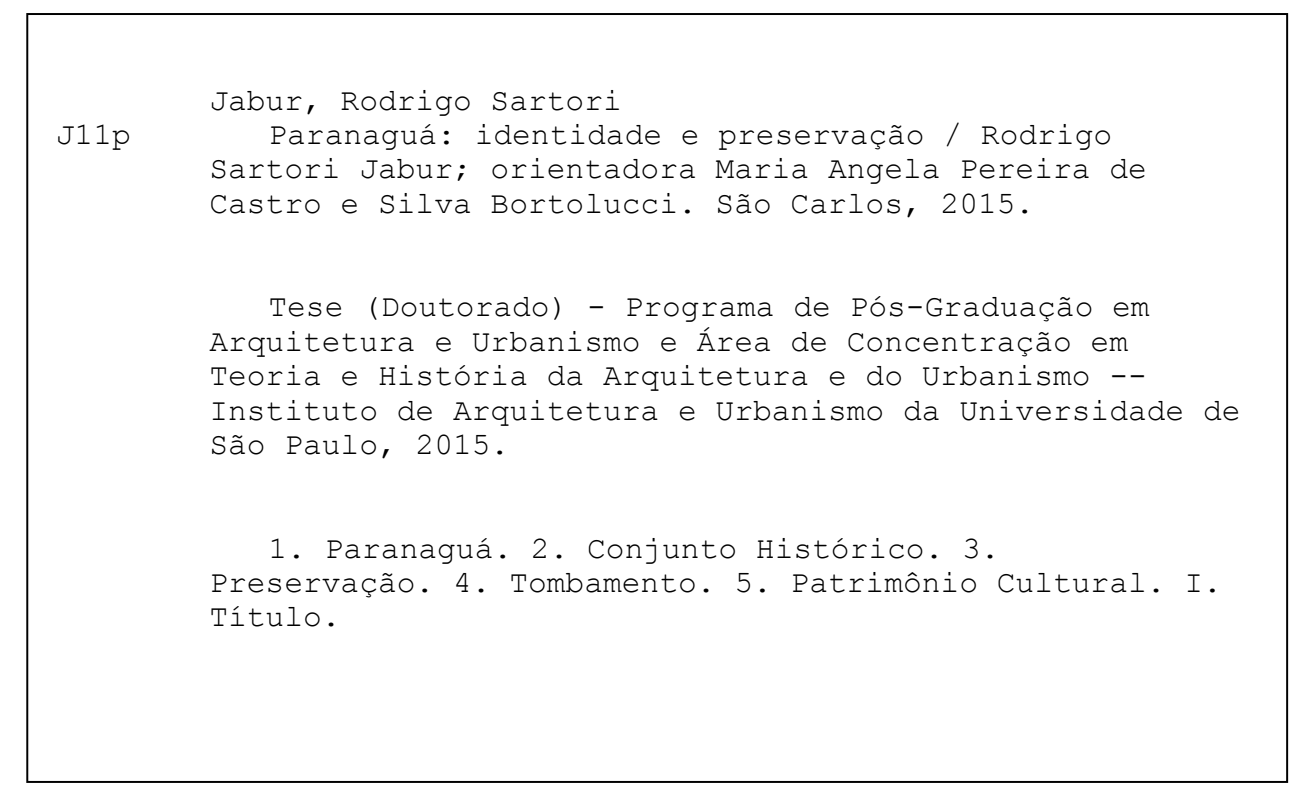




\section{FOLHA DE JULGAMENTO}

Candidato: Arquiteto e Urbanista Rodrigo Sartori Jabur

Título da tese: "Paranaguá: identidade e preservação"

Data da defesa: 21/10/2015

\section{Comissão Julgadora:}

Resultado: Profa. Dra. Maria Angela P. C. S. Bortolucci (orientadora) Mainottropefled ontelucer
(Instituto de Arquitetura e Urbanismo - USP)

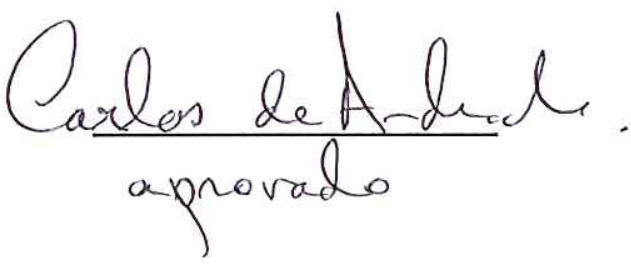

Profa. Dra. Cristiane Souza Gonçalves

(Universidade Cruzeiro do Sul - UNICSUL)

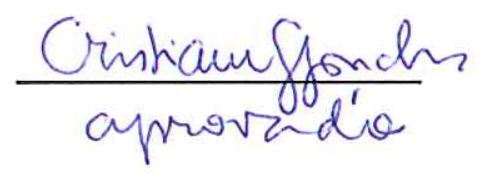

Prof. Dr. Paulo César Garcez Marins

(Museu Paulista- MP/USP)

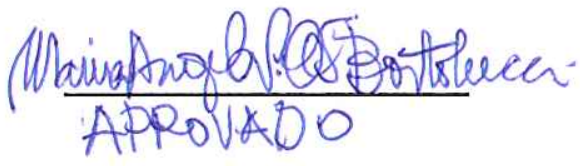

Profa. Dra. Simone Scifoni

simore tuponi

(Faculdade de Filosofia, Letras e Ciências Humanas - FFLCH/USP) amovaclo-

Coordenador e Presidente da Comissão de Pós-Graduação do Programa de PósGraduação em Arquitetura e Urbanismo: Prof. Dr. Márcio Minto Fabrício 



\section{AGRADECIMENTOS}

A partir deste pequeno texto, gostaria de demonstrar minha gratidão a todos que contribuíram durante a trajetória deste doutorado. Apesar de se dizer que a pesquisa é um trabalho solitário, não é possível ser realizada sem a ajuda e a participação de muitas pessoas que estiveram envolvidas de alguma maneira, seja de longe ou de perto.

Em primeiro lugar gostaria de agradecer à minha orientadora Prof. $\mathrm{Dr}^{\mathrm{a}}$. Maria Angela que para mim é um exemplo de dedicação e seriedade em seus trabalhos de pesquisa e orientação, tenho não apenas como orientadora, mas também como amiga. A convivência quase diária na USP foi um grande aprendizado. Agradeço ao seu incentivo naqueles momentos de incertezas e de sua paciência comigo, você é uma referência que vou carregar por toda a vida e tenha certeza que sua contribuição permitiu meu crescimento como pesquisador, por isso sempre digo que tive o privilégio em ser seu orientando.

Agradeço a FAPESP pelo importante apoio financeiro durante todo o período do doutorado, que permitiu a pesquisa nos arquivos em três Estados brasileiros, a participação em eventos científicos e o período sanduíche em Lisboa no ano de 2014.

Tive a oportunidade de aprender muito com as atividades de Estágio em Docência promovidos pela universidade, desta maneira agradeço ao Prof. Dr. Ruy Sardinha, a Prof $^{a}$ Dr $^{a}$ Simone Vizioli e ao Prof. Dr. Paulo Castral que sempre me incentivaram nas atividades das disciplinas e que tornaram esta experiência muito proveitosa.

Durante o doutorado participei de duas pesquisas com temas relacionados às fazendas históricas paulistas, que permitiram conhecer e aprender sobre experiências no campo da preservação deste patrimônio tão peculiar, dessa maneira, agradeço aos professores Dr. Marcos Tognon e Dr ${ }^{a}$ Luzia Sigoli.

Aos funcionários do IAU meu agradecimento, Marcelo, Mara e Geraldo, que sempre foram solícitos e me auxiliaram nas mais diversas situações. Ao pessoal da 
informática Daniel, Evandro, Osvaldo, Kakuda e Paulo obrigado por sempre ampararem nas dificuldades técnicas.

$\mathrm{Na}$ vivência em Lisboa gostaria de agradecer muito ao investigador Dr. João Mascarenhas Mateus pela orientação, por permitir a experiência de pesquisas em Portugal e de conhecer mais seus trabalhos, por compartilhar de seus conhecimentos e por ter me recebido tão bem na Universidade, agradeço também a Diretora do Instituto de História Contemporânea da Universidade Nova de Lisboa, Dra $^{a}$ Maria Fernanda Rollo.

No andamento da pesquisa foram essenciais as visitas aos arquivos, agradeço ao Chefe do Arquivo Central do Iphan no Rio de Janeiro Hilário Figueiredo, aos funcionários da Superintendência do IPHAN em São Paulo e aos funcionários da biblioteca da Superintendência do IPHAN do Paraná. Também gostaria de agradecer a todos aqueles que integram o Instituto Histórico e Geográfico de Paranaguá que sempre estiveram dispostos a contribuir desde as minhas atividades de mestrado.

Agradeço aos entrevistados, que permitiram elucidar fatos, acrescentar informações, e principalmente contar sobre suas experiências com a cidade de Paranaguá. Agradeço aos arquitetos Cyro Correa Lyra, José La Pastina, Rosina Parchen, Luiz Marcelo Bertoli e Humberto Fogassa.

No exame de qualificação, agradeço as contribuições da $\operatorname{Prof}^{a} \operatorname{Dr}^{a}$ Simone Scifoni que foram muito importantes para a condução da pesquisa nesta segunda etapa, agradeço também as análises do Prof. Dr. Carlos Roberto de Andrade.

Aos amigos, estes que tanto compartilharam de alegrias e tristezas e que tem papel importante nesta vida acadêmica em São Carlos, tenho eterna gratidão, são laços de amizade que nunca serão desfeitos. A turminha que sempre me acompanhou nesta trajetória, obrigado Adriana, Ariel, Juliana, Marieli, Paulinha, Pedro e Tássia, apesar das distâncias geográficas de alguns, elas não impedem que esta amizade continue, saibam que sempre estarão nas boas memórias que carrego. Agradeço também aos 
amigos que fiz durante esta trajetória e saibam que vocês têm uma participação especial nessa jornada, Milena, Rodrigo, Helenice, Thaís, Josi, Cris, Carol e Kelen. A minha amiga de salinha, Joana, saiba que tenho uma grande admiração por você, lutadora e com grande capacidade de pesquisa, agradeço por me acompanhar e por compartilhar de suas experiências, desde nossas idas à São Paulo para as disciplinas e todos os momentos em que dividimos nossos percalços nesta trajetória, muito obrigado! Aproveito para agradecer também a Amanda, Natália, Valéria e Vladimir por sempre acompanharem e apoiarem nessa pesquisa.

A amiga Lorenza que sempre me ajudou nesta trajetória, agradeço por suas contribuições e também por sempre me receber de braços abertos e de me apoiar em todos os momentos. Agradeço também à amiga Mariana por sempre me abrigar nas idas à São Paulo e por compartilhar de suas experiências de trabalho.

Aos amigos que fiz em Portugal, e que tornaram o período sanduíche ainda mais agradável, obrigado à Raquel que tornou Lisboa mais "gira”, por me levar a lugares incríveis que só uma lisboeta conhece. Obrigado aos amigos brasileiros que me acompanharam nesta cidade e na Universidade Nova de Lisboa, Raquel Longhi, Juliana, Tarci e Régia.

Por fim, não posso deixar de agradecer à minha família, que sempre me apoiou neste doutorado, eu gostaria de estar mais presente, mas mesmo com a distância vocês tem um papel essencial em tudo isso, obrigado aos meus pais Issa e Elair e as minhas irmãs Andrea, Danielle e Simone. 



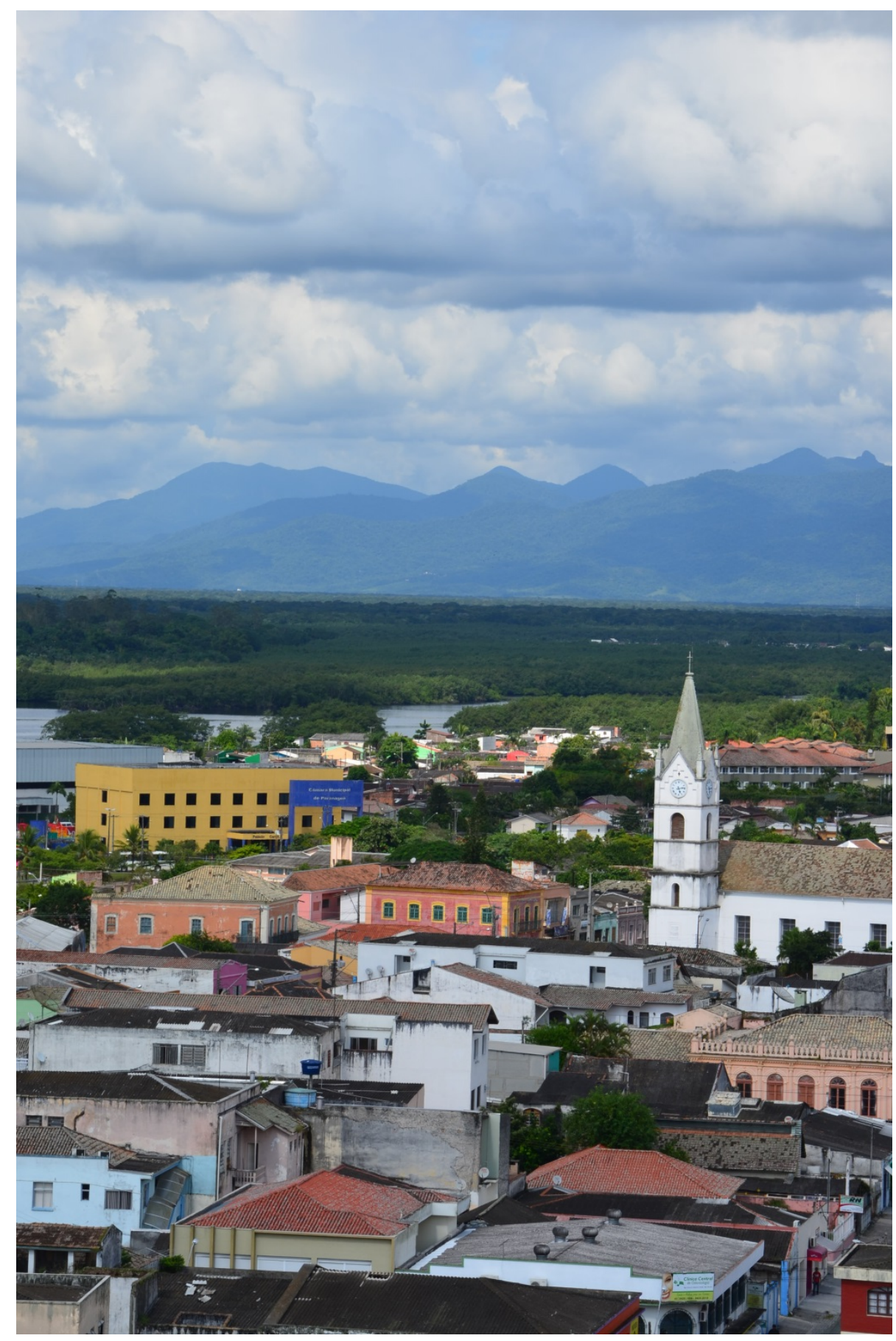

Dedico à minha avó Graciosa Cin memoriam\}, que tantas boas memórias eu tenho guardadas. 



\section{'RESUMO}

Estuda as ações de transformação e preservação do conjunto histórico de Paranaguá no século XX e início do XXI, partindo do primeiro ato de preservação em caráter nacional, o tombamento Colégio dos Jesuítas em 1938 pelo antigo Serviço do Patrimônio Histórico e Artístico Nacional, até o reconhecimento do conjunto histórico em 2009 pelo Instituto do Patrimônio Histórico e Artístico Nacional. A partir de três edifícios representativos na cidade, Colégio dos Jesuítas e igrejas de São Benedito e da Ordem Terceira de São Francisco das Chagas, analisa as atividades do Serviço do Patrimônio, como também os fatos que influenciaram na decisão sobre a delimitação e o tombamento do conjunto histórico. Analisa, ainda, a importância dessa área preservada no contexto urbano de Paranaguá com forte apoio da revisão bibliográfica a partir de autores como Márcia Chuva, Maria Cecília Londres, José Reginaldo Gonçalves, Lia Mayumi, Márcia Sant’Ana e Cristiane Gonçalves e de fontes documentais primárias como cartas, pareceres, relatórios, peças gráficas, croquis e fotografias. Além disso, também realiza entrevistas, buscando as ações realizadas pelos órgãos oficiais neste patrimônio. Dessa forma, a pesquisa se insere no quadro de discussões relativas à preservação de conjuntos históricos no Brasil, contribuindo particularmente para avaliar o papel da população nas decisões de proteção do patrimônio cultural.

Palavras-chave: Paranaguá. Conjunto Histórico. Preservação. Tombamento. Patrimônio Cultural. 



\section{ABSTRACT}

Studies the transformation and conservation of the city of Paranagua historical ensemble during the 20th and beginning of the 21 st centuries starting from the first national act of preservation, the listing of the Colégio dos Jesuítas (Jesuit college) in 1938 by the former National Historical and Artistic Heritage Service until the recognition of the historical ensemble in 2009 by the Institute of National Historical and Artistic Heritage. Considering three representative buildings in the city - the Jesuit College and the churches São Benedito and thesis Ordem Terceira de São Francisco das Chagas - the thesis analyses the activities of the Heritage Service as well as the facts that influenced in the decision regarding the delimitation and listing of the historical ensemble. The thesis also analyses the importance of this preserved area in the urban context of Paranagua and is strongly supported by the bibliographical revision of texts by authors such as Márcia Chuva, Maria Cecília Londres, José Reginaldo Gonçalves, Lia Mayumi, Márcia Sant'Ana and Cristiane Gonçalves as well as primary sources of documents such as letters, reviews, reports, graphic pieces, sketches and photos. It also analyses interviews that highlight activities conducted by official bodies on this heritage. This way, the research is considered part of the debate on preservation of historical areas in Brazil and provides a special contribution to the evaluation of the role played by public participation in decisions regarding the protection of cultural heritage.

Key-words: Paranaguá. Historical Ensemble. Preservation. Act of Preservation. Cultural Heritage. 



\section{SUMÁRIO}

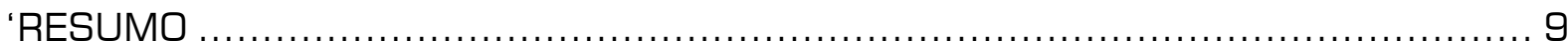

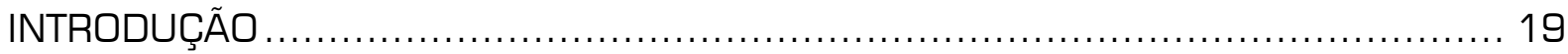

CAPÍTULO 1 - AS RELAÇÕES DE TRABALHO: RODRIGO MELO FRANCO, JOSÉ LOUREIRO FERNANDES E DAVID CARNEIRO

CAPÍTULO 1.1 - DAVID CARNEIRO E O SPHAN: A SELEÇÃO DE OBRAS NOTÁVEIS NO PARANÁ.

1.2 RODRIGO MELO FRANCO DE ANDRADE E JOSÉ LOUREIRO FERNANDES: O COLÉGIO DOS JESUÍTAS.

CAPÍTULO 2. CONFLITOS E DISPUTAS NA CONSERVAÇÃO DO PATRIMÔNIO

PARNANGUARA

2. 1 IGREJA, MUSEU, SALA DE CONCERTOS OU TEATRO? A IGREJA DA ORDEM TERCEIRA DE SÃO FRANCISCO DAS CHAGAS

IGREJA DE SÃO BENEDITO: LIMPEZA ESTILÍSTICA PRODUZINDO UMA UNIDADE HISTÓRICA

CAPÍTULO 3 - DO PLANO DE 1968 AO TOMBAMENTO DE 2009: CENTRO HISTÓRICO DE PARANAGUÁ

3.1 MISE EN VALEUR: AS INFLUENCIAS INTERNACIONAIS E A PROTEÇÃO DO PATRIMÔNIO URBANO DE PARANAGUÁ PELO PLANO DIRETOR DE 1968..............156

3.2 PARANAGUÁ: CIDADE PATRIMÔNIO

3.3 A CLASSIFICAÇÃO DO PATRIMÔNIO URBANO: PARANAGUÁ PAISAGEM OU HISTÓRIA?

3.4 PARANAGUÁ: O PORTO COMO PAISAGEM.

CONCLUSÃO 228

CARTAS, RELATÓRIOS, OFÍCIOS, PARECERES E ATAS. 234

REFERÊNCIAS 



\section{INDICE DE ILUSTRAÇÕES}

Figura 1: Páginas da carta de David Carneiro enviada a Rodrigo Melo Franco de Andrade, em abril de 1937, em que está contida a sugestão dos bens a serem tombados no Paraná. ............................................ 36 Figura 2: Fichas do SPHAN preenchidas por David Carneiro, provavelmente em 1937, com os dados do antigo Convento Jesuíta.

Figura 3: Fichas do Sphan preenchidas por David Carneiro com os dados do Palacete Visconde de Nácar.

Figura 4: Regionais estabelecidas pelo decreto n³78 de 13 de janeiro de 1937 ...........................................42

Figura 5: Distritos da Diretoria do Patrimônio Histórico e Artístico Nacional............................................. 43

Figura 6: Organização da Sede Geral da Diretoria do Patrimônio Histórico e Artístico Nacional. ............. 43

Figura 7: Desenhos de David Carneiro do antigo Convento Jesuíta apresentando o claustro..................... 48

Figura 8: Casas na rua Fernando Simas, reparar que ainda se mantinha o calçamento antigo. .....................5 50

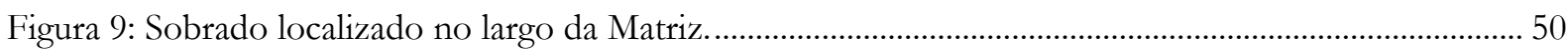

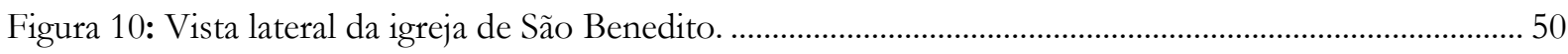

Figura 11: Vista do Colégio dos Jesuítas a partir da rua da Praia, antes da primeira restauração.................. 51

Figura 12: Imagem de uma das paredes da fachada da Rua da Praia, percebe-se o desgaste dos

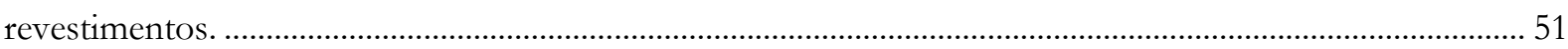

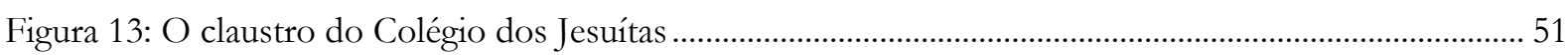

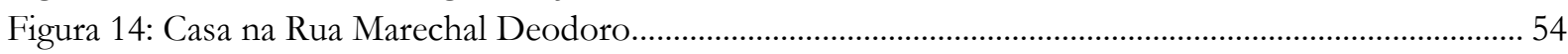

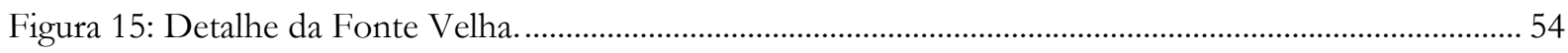

Figura 16: A fotografia apresenta um dos discursos de Loureiro Fernandes (ao centro da imagem) na Câmara Municipal de Paranaguá durante os festejos do tricentenário em que está presente Luís Saia (no canto esquerdo em pé de paletó claro).....

Figura 17: panorama geral do edifício do Colégio Jesuíta, o rio Itiberê ainda estava próximo ao monumento. Na extremidade esquerda do edifício está a sede do IHGP.....

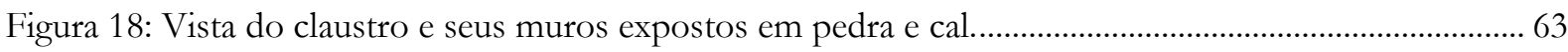

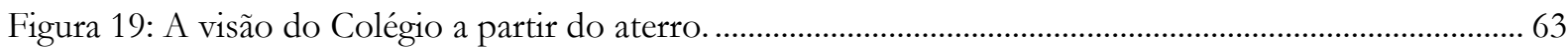

Figura 20: Registro fotográfico das escavações arqueológicas com registros escritos de José Loureiro Fernandes.

Figura 21: Proposta para o novo acesso do museu apresentada por Luís Saia em abril de 1960.

Figura 22: Imagens das obras em andamento, acima a parede de pedra e cal, ao centro as ruínas da antiga igreja, abaixo as ruínas da igreja e o edifício do IHGP.

Figura 23: A segunda proposta de Luís Saia para o novo acesso ao museu em junho de 1961...................68

Figura 24: Alguns aspectos da ruína e sua interligação com o claustro do Colégio dos Jesuítas................... 69

Figura 25: As duas janelas da fachada voltada para o rio Itiberê, apresentam em suas vergas no ano de 1956 ao que parece cobertas por argamassa, em 1958 as vergas foram substituídas por concreto com desenho diferente das demais, e na última imagem em 2013 .................................................................. 73

Figura 26: Vista do Colégio a partir da rua da Praia ..................................................................................... 73

Figura 27: Fachada do Colégio a partir da rua da Praia após a primeira fase da restauração........................ 74

Figura 28: Imagem das modificações realizadas na face voltada para a Rua XV de Novembro, acima o estado em que se encontrava antes da restauração, abaixo o pequeno anexo com a retirada da platibanda e a entrada lateral com a retirada do alpendre. Fonte: Acervo do autor, 2013 ................................................. 76 Figura 29: Croqui de Carlos Contin que complementa a carta sobre as propostas de restauro no Colégio Jesuíta, como a demolição da área da fachada demarcada com o item a.

Figura 30: Imagens do incêndio da igreja da Ordem enviadas por José Loureiro Fernandes em novembro de 1960, acima o acesso à sacristia e na imagem abaixo o altar. Fonte: Arquivo Central. 
Figura 31: Imagens obtidas do relatório de Cyro Corrêa Lyra sobre a restauração da igreja da Ordem em 1966, observa-se o refazimento total da cobertura com estrutura em madeira, na imagem ao centro percebe-se o uso do concreto para a correção de fissuras acima do arco cruzeiro.

Figura 32: Acima, o altar da igreja da Ordem, antes do incêndio de 1960, abaixo a imagem de vestir de São

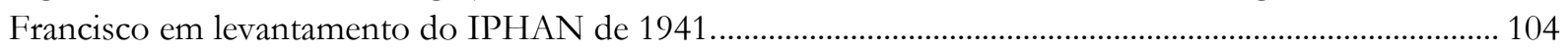

Figura 33: O retábulo colocado na igreja da Ordem Terceira na década de 1970........................................ 105

Figura 34: A única foto a cores encontrada deste restauro: notar o brilho das paredes resultantes da aplicação de verniz.

Figura 35: Reproduções de fotografias do levantamento de José Saia Neto em 1981: notar o detalhe da porta principal, com quadro manchado pelo Neutrol e madeira excessivamente brilhante; ver também o detalhe do cunhal manchado pelo mesmo produto.

Figura 36: Fachada principal da igreja de São Benedito em 1940. Fonte: Hess, Erich, Arquivo Central do

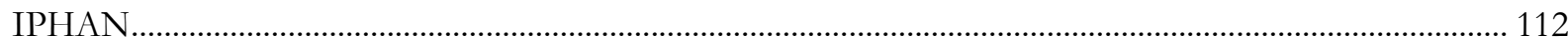

Figura 37: Os altares colaterais e o altar -mor da igreja de São Benedito provavelmente em 1940........... 112 Figura 38: Uma das visitas dos alunos a Paranaguá, do lado esquerdo de paletó cinza está Cyro Corrêa Lyra, ao fundo a igreja de São Benedito, ainda amarela. Fonte: Acervo Cyro Corrêa Lyra .......................... 113 Figura 39: Planta da igreja de São Benedito após a primeira restauração. Fonte: Levantamento IPHANPR, Adaptado pelo autor 2015

Figura 40: Uma das fotografias do levantamento da igreja de São Benedito, notar a grande fissura no frontão próximo da janela direita.

Figura 41: Fotografias do levantamento gráfico de Cyro Corrêa Lyra em 1965, acima a fachada principal onde se percebe no frontão ao lado esquerdo a rachadura.; ao centro Cyro, do lado esquerdo acompanha os levantamentos em São Benedito; abaixo a pequena abertura ainda existente aos fundos da igreja de São Benedito. Fonte: Arquivo Central do IPHAN e Arquivo IPHAN-PR 118 Figura 42: A igreja descoberta e a construção da cinta em concreto no topo das paredes desprotegidas. Fonte: Acervo IPHAN-PR.

Figura 43: Acima, o encarte sobre a restauração da igreja de São Benedito, publicado em 1967, apresenta algumas fotografias da retirada e reconstrução da cobertura. Nas imagens abaixo fissuras encontradas na parede lateral da igreja em 1967 e a aplicação de presilhas metálicas e cimento para a consolidação das fissuras. Fonte: Acervo IPHAN-PR e IPHAN-SP.

Figura 44: Missa inaugural da restauração da igreja de São Benedito em 1967. A igreja está completamente limpa dos acréscimos oitocentescos. Destaque para as pequenas peanhas nas duas laterais do arco cruzeiro.

Figura 45: O altar mor restaurado, 1967. Fonte: Acervo IPHAN-PR.

Figura 46: Acima Beatriz Pelizzeti e Cyro Corrêa Lyra, defronte à porta principal da igreja de São

Benedito.1966-1967 e abaixo Beatriz iniciando os trabalhos de restauração da imagem de São Benedito.

Fonte: Acervo IPHAN-PR.

Figura 47: O mapa dos monumentos, baseando- se nas informações encontradas no artigo de Luís Saia

Figura 48: Inauguração da restauração da igreja de São Benedito em 1967. Estão na fotografia 1. Enio Marques Ferreira; 2. Dalena Guimarães Alves, 3.Cyro Correa Lyra; 4. Beatriz Pelizetti; 5. D. Graciema, esposa de Rodrigo Melo Franco de Andrade; 6. Newton Carneiro; 7. Professora Porcia Guimaraes Alves, irmã de Dalena; 8. Rodrigo Melo Franco de Andrade; 9. Renato Soeiro; 10. D. Judite Martins, secretária do Sphan; 11. esposa do Prefeito de Paranaguá; 12. Prefeito Nelson Barbosa e 13. D. Elza Carneiro, esposa de Newton Carneiro. (A identificação foi possível graças a Cyro Corrêa Lyra). Fonte: Acervo de Cyro Corrêa Lyra

Figura 49: Localização dos lotes e o Colégio Jesuíta em imagem aérea de 2014, o lote 1 estava vazio, o lote 2 e 3 ocupados. 
Figura 51: Localização da igreja de São Benedito e aos fundos o reservatório d'água.................................147

Figura 52: Croquis de Cyro Corrêa Lyra para o Plano Diretor de Paranaguá. .............................................. 152

Figura 53: Fotografia de Fez em 1917, as muralhas de proteção da Medina e o cinturão verde proteção

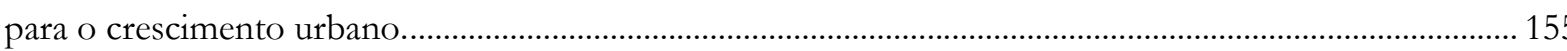

Figura 54: As duas imagens, do Plano de 1968, apresentam a situação encontrada nas margens do Rio

Itiberê, na altura do Colégio Jesuíta e abaixo a proposta da via turística na área ribeirinha........................ 160

Figura 55: Delimitação do centro histórico proposta por Cyro Corrêa Lyra para o Plano Diretor de

Paranaguá.

Figura 56: Apesar de manter a escala urbana, Paranaguá sofreu com a construção de alguns edifícios desproporcionais ao contexto urbano. Fonte: Acervo do autor, 2013

Figura 57: Uma das publicidades de Paranaguá que retratam a Rua General Carneiro, também conhecida por Rua da Praia. Fonte: Revista Paraná em Páginas.

Figura 58: A formação dos oito distritos na gestão de Renato Soeiro.

Figura 59: Um dos trechos do levantamento de José La Pastina para o centro histórico de Paranaguá, os edifícios foram catalogados e localizados num mapa base de fins do século XIX...................................... 176

Figura 60: Mapa da delimitação do tombamento estadual. .......................................................................... 184

Figura 61: Mapa da delimitação do tombamento Federal........................................................................... 197

Figura 62: Panorama da área da foz do Rio Itiberê, o grande morro ao fundo é a ilha da Cotinga. .......... 201

Figura 63: Panorama da área portuária de Paranaguá, como pano de fundo a Baía de Paranaguá e a Serra do Mar.

Figura 64: O Castelo de São Jorge envolto pelos bairros da Alfama e Mouraria. Fonte: Acervo do autor, 2014.

Figura 65: As atividades portuárias em Alcântara, nas proximidades do Museu Nacional de Arte Antiga.

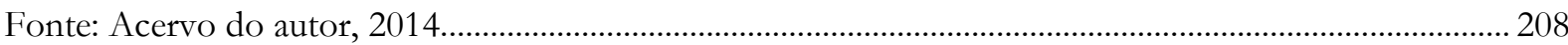

Figura 66: A Zona da Expo 98. Fonte: Acervo do autor, 2014 .................................................................208

Figura 67: A ciclovia nas proximidades do Museu da Eletricidade. Fonte: Acervo do autor, 2014.......... 210

Figura 68: A ciclovia e os cabeços na região próxima ao Cais do Sodré. Fonte: Acervo do autor, 2014. . 211

Figura 69: As atividades portuárias visíveis no percurso da ciclovia. Fonte: Acervo do autor, 2014.........212

Figura 70: As plataformas à beira do Tejo na Ribeira das Naus. Fonte: Acervo do autor, 2014............... 213

Figura 71: Trecho às margens do rio Itiberê, em Paranaguá. Fonte: Acervo do autor, 2012. .................... 216 



\section{INTRODUÇÃO}

O nosso interesse pela preservação do patrimônio de Paranaguá ocorreu como um desdobramento da pesquisa de mestrado, momento em que analisamos suas transformações urbanas e arquitetônicas durante os séculos XVIII e XIX. Naquela oportunidade nos deparamos com valiosas informações sobre o tombamento federal de um dos edifícios mais emblemáticos da cidade no bojo das primeiras atividades do IPHAN no Brasil. A partir daí, muitas indagações a cerca da preservação de Paranaguá passaram a nos inquietar, entre elas: por que um edifício localizado em uma cidade aparentemente de pouca relevância para os técnicos do Serviço do Patrimônio teria um edifício tombado tão precocemente? E foi ainda durante o desenvolvimento da pesquisa de mestrado que outro fato importante iria contribuir ainda mais para alimentar o nosso interesse: em 2009 o centro histórico de Paranaguá foi inserido no rol de cidades históricas reconhecidas pelo IPHAN.

Desse modo, fomos envolvidos pelo tema e decidimos dar prosseguimento às nossas investigações em Paranaguá no âmbito do doutorado e tentar descobrir: como se deu o início das atividades de preservação em Paranaguá. Por que o centro histórico foi tombado em 2009? De que maneira as restaurações dos principais monumentos da cidade foram executadas e quem foram os agentes envolvidos? Como se deu a proteção do centro histórico de Paranaguá? Para responder a estas questões foi necessário empreender uma busca incessante por documentos e outros materiais que permitiu penetrar nos meandros do Serviço de Patrimônio e compreender as razões que asseguraram a preservação deste patrimônio.

A hipótese de nossa tese é de que as redes de relações entre os representantes do IPHAN e as figuras-chave do Paraná permitiram a inserção de Paranaguá nas discussões e atividades do Patrimônio, apesar de se imaginar, pela 
bibliografia sobre o tema, que a cidade não teria visibilidade no mapa da preservação no Brasil.

Estabelecemos como objetivo geral a necessidade de compreender a relação entre o IPHAN e a cidade de Paranaguá que resultaram nos tombamentos e nas restaurações. Consequentemente seria pertinente analisar as atividades iniciais do IPHAN no Paraná e mais precisamente em Paranaguá ainda na década de 1930; compreender a rede de relações estabelecidas entre as figuras-chave e seu papel nas atividades de proteção do patrimônio parnanguara; analisar os métodos de restauração empreendidos nas igrejas de São Benedito, da Ordem e no Colégio dos Jesuítas e por fim analisar as ações de proteção do centro histórico de Paranaguá, suas influências e o tombamento federal em 2009.

Paranaguá, cidade litorânea paranaense, foi incluída nas ações do órgão oficial do patrimônio nacional, ainda na década de 1930. Apesar de situar-se numa região que aparentemente não estava nas prioridades da instituição naquele momento, teve um edifício selecionado nas primeiras listagens de bens tombados nacionalmente. Destas afirmações surgiram questionamentos que nos apontaram para a necessidade de observar com mais cautela esses meandros das atividades de seleção e registro, bem como os procedimentos pelos quais as atividades de preservação, conservação e restauro se desencadearam nas próximas décadas.

A atuação do IPHAN ${ }^{1}$ nas primeiras três décadas foi amplamente discutida por diversos autores ${ }^{2}$. Dessa maneira, apresentamos nesse texto as principais

\footnotetext{
1 Preferimos denominar a instituição com seu nome atual, ao invés das outras nomenclaturas adotadas ao longo dos anos. Vale lembrar que: “O Sphan foi organizado pelo Decreto n.25, de 30.11.1937. Em 1946 foi transformado em Diretoria sob a sigla Dphan; em 1970 passou a ser Instituto - Iphan -, e nove anos depois, como Secretaria, voltou a Sphan. Em 1981, mantendo essa sigla, transformou-se em Subsecretaria e, em 1990, passou a denominar-se Instituto Brasileiro de Patrimônio Cultural (IBPC), voltando a ser, em1994, ainda em caráter provisório, Instituto do Patrimônio Histórico e Artístico Nacional (Iphan). (RODRIGUES, 1994, p.14)

${ }^{2}$ Dentre os quais podemos citar: ANDRADE, Antonio Luiz Dias de. Estado Completo que Pode Jamais ter Existido. 1992. Tese (Doutorado em Arquitetura e Urbanismo) - Faculdade de Arquitetura e Urbanismo - USP. CHUVA, Márcia Regina Romeiro. Os Arquitetos da Memória: sociogênese das práticas de preservação do patrimônio cultural no Brasil (anos 1930-1940). Rio de Janeiro: Editora da UFRJ, 2009. FONSECA, Maria Cecília Londres. O Patrimônio em Processo: Trajetória da Política Federal de Preservação no Brasil. Rio de Janeiro: UFRJ: IPHAN, 1997. MICELI, Sergio. SPHAN: Refrigério da Cultura Oficial. Revista do Patrimônio Histórico e Artístico Nacional. Rio de Janeiro, no 22, p. 44-47, 1987. MILLET, Vera. A Teimosia das Pedras: Um estudo sobre a preservação do patrimônio ambiental no Brasil. Olinda: Prefeitura de Olinda, 1988. RUBINO, Silvana. O Mapa do Brasil Passado. Revista do Patrimônio Histórico e Artístico Nacional. Rio de Janeiro, no 24, p. 96-105,
} 
referências que embasaram nossa pesquisa, relacionando-as com as especificidades da cidade na construção de uma fundamentação teórica que permitiu analisar a rede de relações e ações na preservação do patrimônio histórico em Paranaguá.

Esse discurso oficial que permeia as atividades da instituição foi alvo de um abrangente leque de estudos que analisaram, principalmente a partir da década de 1990, a atuação do IPHAN, na denominada Fase Heroica (1937-1969), na administração de Rodrigo Melo Franco de Andrade (1898-1969). Dessa forma, essas análises partiram das diversas áreas do conhecimento como da história, antropologia, sociologia, geografia e da arquitetura e apontam esse momento como a construção de um ideário de nação que terá na arquitetura do período colonial sua grande representação, são estas referências fundamentais para construir nossas análises.

Segundo José Reginaldo Gonçalves³ (1996), este ideário é formado por um conjunto de fragmentos resultantes de uma pré-seleção: edifícios, cidades, bens móveis, que nos discursos oficiais são reconhecidos e preservados justamente pela possibilidade da perda. Risco que afeta não apenas o conjunto de bens selecionados, que são vistos como uma totalidade, mas prejudica principalmente aquilo em que o patrimônio foi posto como função: a construção da identidade nacional.

Assim o conjunto ou "modelo reduzido", que representaria o passado nacional foi analisado por Rubino (1996, p.98):

\begin{abstract}
Esse conjunto, que podemos chamar de modelo reduzido, seria a marca da cultura e da civilização, oposição e resposta a categorias como território, paisagem, natureza. Somente através dessa marca humana seria possível recompor o caráter nacional do país, e Rodrigo chegou a chamar esse conjunto de documentos de identidade. $\mathrm{O}$ conjunto eleito revela $\mathrm{o}$ desejo por um país passado, com quatro séculos de história, extremamente católico, guardado por canhões, patriarcal, latifundiário, ordenado por intendências e casas de câmara e cadeia, e habitado por personagens ilustres, que caminham entre pontes e chafarizes.
\end{abstract}

1996. Disponível em: www.iphan.gov.br Acesso em: 10/07/2010. SANTOS, Mariza Velloso Motta. Nasce a Academia SPHAN. Revista do Patrimônio Histórico e Artístico Nacional. Rio de Janeiro, no 24, p. 77 - 95.1996. ${ }^{3}$ Sociólogo, autor do livro a Retórica da Perda, em que analisa as atividades do patrimônio nacional pelo viés dos discursos de dois importantes diretores da instituição Rodrigo Melo Franco de Andrade e Aloísio Magalhães. 
Esse modelo reduzido teria como principal referência o patrimônio identificado em Minas Gerais e a análise de muitas obras de outras regiões brasileiras tiveram como parâmetro as construções mineiras. As edificações dessa região foram amplamente divulgadas em diversas publicações nacionais e internacionais e estabeleceram definitivamente uma imagem do passado brasileiro, como coloca Marcia Chuva (2009, p. 63):

Esse patrimônio mineiro foi de tal forma reproduzido em revistas, jornais, mapas, folhetos etc. que, multiplicando-se infinitamente, tornouse ícone máximo de "brasilidade" na escala de valores que se impôs. O IPHAN esteve, sem dúvida, aderido ao projeto de nacionalização implementado pelo Estado Novo, ao unificar uma escala hierárquica de valores patrimoniais a partir de um padrão de arte e arquitetura determinado pela produção mineira colonial. As inúmeras frentes de ação integracionistas abertas pelo governo varguista redundaram em amplas medidas visando a nacionalização, tendo sido o Ministério da Educação e Saúde do mineiro Gustavo Capanema, uma das agências de ponta nesse projeto.

Produção mineira, religiosa e militar, são características que exemplificam o tom das ações de preservação do IPHAN nas primeiras décadas, tendo como ponto de partida as listas de bens tombados definidas pela instituição em 1938. Temos o registro de 235 bens, dentre os quais, dominam esse rol, as construções religiosas que contam com quase $60 \%$ do total. Ainda nesse ano, dentre as congregações beneficiadas, encontram-se as Ordens Carmelitas e Franciscanas com o maior número de igrejas e conventos tombados. E no caso dos jesuítas, apenas 7 monumentos dentre os aproximadamente 30 que foram tombados entre 1938 e 2009. E nesse sentido salientamos que entres os primeiros selecionados dessa ordem religiosa, inclui-se o Colégio dos Jesuítas de Paranaguá.

No âmbito urbano, a primeira ação de preservação de conjuntos no Brasil ocorreu antes da criação do Serviço do Patrimônio Histórico e Artístico Nacional, com o reconhecimento de Ouro Preto como monumento nacional em 1933 a partir da Inspetoria de Monumentos Nacionais. Essa iniciativa suscitou outras ações em cidades mineiras como Tiradentes, Mariana, Serro, Diamantina, Congonhas e 
Sabará que também se tornaram cidades representativas do patrimônio nacional entre as décadas de 1930 e 1940. (RUBINO, 1996). Essa escolha e seleção de cidades como no caso de Ouro Preto, deve não apenas ser analisada à luz dos preceitos de preservação, dos valores de patrimônio, estético, histórico, etc., mas inclusive por motivações ideológicas que buscavam identificar, além de monumentos isolados, o caráter de conjunto identitário da nação brasileira. (RUFFINONI, 2010). Seguindo esse raciocínio, compreendemos a sugestão de David Carneiro (1904-1990) de incluir a cidade da Lapa (Paraná) na lista enviada a Rodrigo Melo Franco de Andrade, com a justificativa do envolvimento da cidade na revolução federalista do final do século XIX. A sugestão não foi aceita, mas, afinal, a Lapa teve seu reconhecimento como patrimônio nacional em 1990, lembrando que sua principal igreja, Matriz de Santo Antônio, já havia sido tombada em 1938 com registro no livro de Belas-Artes. A igreja, que possui características do período colonial, tem fortes semelhanças com a igreja da Ordem e de São Benedito em Paranaguá, essa constatação nos permitiu inferir algumas reflexões que nortearam nossas investigações: por que a igreja de Santo Antônio foi tombada em 1938 e as duas igrejas de Paranaguá apenas em 1967? E por que apenas a igreja de Santo Antônio está incluída no livro de Belas -Artes e as igrejas parnanguaras estão apenas no livro do tombo histórico? Por que razão os critérios de seleção se alteravam critérios na escolha dos monumentos representativos com vistas ao tombamento a ponto de ocorrer a classificação de casos semelhantes em livros de tombo distintos? Pela documentação é perceptível a centralização das ações de tombamento, mas percebemos que ocorriam divergências na sua classificação. A tomada de decisão, no momento de selecionar em qual livro o monumento deveria ser registrado é conflituosa: afinal em quais critérios se embasavam os técnicos na classificação do patrimônio cultural brasileiro, mais precisamente nesse período?

O tombamento da igreja de Santo Antonio, na Lapa, em 1938, se deve à lista que David Carneiro enviou a pedido de Rodrigo Mello Franco. Ou seja, muito do que foi selecionado nas regiões, fora do eixo principal, teve como base a análise de 
registros fotográficos e descrições, realizados por pessoas que ainda não estavam diretamente ligadas ao IPHAN e pressupunha a confiabilidade dos dados apresentados.

Analisando os projetos e obras de restauro executados em Paranaguá e o diálogo presente nas cartas entre os técnicos, nos colocam as seguintes questões: Seria possível afirmar que existia um procedimento padrão para as obras de restauro nos monumentos parnanguaras? Estes procedimentos eram embasados em algum aporte teórico? Como transcorria o diálogo entre as instâncias, federal, estadual e municipal?

Os técnicos de São Paulo e do Rio de Janeiro tiveram forte influência nas atividades de preservação do patrimônio em Paranaguá, porque foram eles os responsáveis pelas obras na cidade e também porque a Diretoria paulista atuou no Estado do Paraná até 1990. Podemos afirmar que os casos mais emblemáticos sobre responsabilidade da Diretoria paulista referem-se ao estudo e restauro das casas bandeiristas e à atuação do arquiteto Luís Saia. Analisando pelo viés dos procedimentos e técnicas empregadas, o estudo de Lia Mayumi (2008) nos esclarece sobre o assunto. A autora aponta que existia um modelo de procedimentos nas obras das casas bandeiristas que acabaram se tornando um "padrão", isso se caracterizava pelo exaustivo uso do cimento como solução restaurativa, seja nas estruturas de concreto para consolidação das taipas, na reintegração de lacunas, seja no uso de placas de concreto, provavelmente inspirado nos preceitos da Carta de Atenas (1931) que recomendava o uso de técnicas modernas de conservação e assim o concreto foi o material mais difundido e utilizado naquele período.

Cristiane Gonçalves, que analisa a atuação da direção paulista entre 1937 a 1970, afirma que, apesar das mudanças conceituais no campo da restauração, como por exemplo, a Carta de Veneza (1964), a condução das restaurações em São Paulo manteve as técnicas e tecnologias empreendidas desde as primeiras atividades da 
Diretoria, caracterizada pelo emprego do concreto armado e da reconstituição de trechos desaparecidos dos edifícios, como por exemplo, nas obras da Fazenda Pau d'Alho (São José do Barreiro). O concreto, apesar da justificativa de uso do material contemporâneo de maneira a diferenciar do material original, foi ocultado através dos revestimentos que tem por fim manter a unidade do conjunto.

A reconstituição da almejada imagem original foi um dos preceitos que caracterizaram as restaurações paulistas, a ambientação dos edifícios era resultante de um processo que englobava a demolição de edificações e a recomposição da paisagem, como foi o caso do Sítio de Santo Antônio (São Roque). São operações que dão um caráter de novidade ao edifício antigo. (MAYUMI, 2008).

Dessa maneira, os edifícios restaurados em Paranaguá puderam nos guiar nas análises, casos como do Colégio Jesuíta de Paranaguá, transformado em museu, retrata os ideais e procedimentos empreendidos exclusivamente por técnicos do IPHAN, e são situações que demonstram os conflitos e contradições que permeiam as atividades e os envolvidos neste caso.

Os anos de 1968, 1991 e 2009 são momentos chave para compreendermos de que maneira o centro histórico foi delimitado, primeiro com o Plano Diretor, depois com o tombamento estadual e por fim com o tombamento federal. Surgem aí questões como de que maneira os edifícios tombados pelo IPHAN influenciaram na delimitação do centro histórico? Quais critérios foram estabelecidos para a configuração do que hoje é conhecido por centro histórico? A delimitação permitiu estabelecer a ideia de um conjunto? Quanto ao porto, qual importância foi dada a este elemento tão presente na origem e formação da cidade?

Foi também, a partir da leitura dos documentos levantados nos diversos arquivos, que percebemos um ponto a ser destacado sobre o tema: a forte relação estabelecida entre os profissionais do IPHAN e algumas figuras-chave no Paraná. Figuras-chave por se tratarem de pessoas que inseriram Paranaguá nas ações da instituição. 
Essas relações são um ponto importante de análise da preservação em Paranaguá, pois a partir delas que se estabeleceu, por exemplo, a implantação do Museu de Arqueologia e a restauração do Colégio dos Jesuítas. Nesse monumento associamos o nome do Prof. José Loureiro Fernandes, que possuía contato com o Diretor Rodrigo Melo Franco. As atividades realizadas nas restaurações do museu foram autorizadas pela Central carioca e supervisionadas pela D.R paulista. O poder de decisão estava centralizado no Rio de Janeiro, onde qualquer ação que envolvesse não só edifícios tombados, eram reportados à Rodrigo Melo Franco.

Outro foco importante de nossa análise são as atuações dos prefeitos parnaguaras, o seu interesse, ou não, pela preservação do centro histórico permitiu que em certos momentos ocorressem iniciativas como, por exemplo, as tentativas para o tombamento desde os anos 1980; a valorização da história de Paranaguá nos festejos do Tri-centenário em 1948; e paradoxalmente, as ameaças de demolições e o franco desinteresse pelo centro histórico em fins dos anos 1980.

A fonte principal da pesquisa foi a documentação primária existente nos arquivos do IPHAN e era necessário compreender toda a dinâmica administrativa do órgão para dar início às buscas com segurança. Sabíamos que o Paraná foi subordinado à São Paulo durante as primeiras décadas de atividade e, portanto, parte destes arquivos poderiam estar lá, na $9^{a}$ Divisão, localizada na capital paulista. Documentos mais antigos ainda estão no Arquivo Central no Rio de Janeiro e, finalmente, os mais recentes no arquivo do IPHAN do Estado do Paraná.

A busca por documentos nos arquivos foi orientada em função do tombamento de três monumentos da cidade: Colégio dos Jesuítas (1938), Igreja da Ordem Terceira de São Francisco das Chagas (1967) e Igreja de São Benedito (1967) e do centro histórico de Paranaguá (2009). A vastidão de documentos, dos mais variados conteúdos, é constituída, principalmente, pelas cartas trocadas entre os técnicos do IPHAN e aqueles envolvidos com as atividades no Paraná. Há também os relatos sobre os tombamentos, as obras de restauração, os problemas administrativos, a falta de verbas, a falta de diálogo entre as instâncias. Também 
incluem orçamentos, algumas peças gráficas e croquis. Não podemos deixar de lembrar o grande volume de fotografias, de diversas décadas: que são valiosos registros da cidade, dos monumentos e das obras de restauração. Complementam a documentação pesquisada, as atas da Câmara Municipal de Paranaguá, a legislação estadual e municipal, jornais e a bibliografia pertinente.

O processo de coleta, organização e análise dos documentos, foi nos permitido compreender as situações que levaram ao tombamento e às restaurações em Paranaguá. Focamos a organização dos arquivos a partir dos edifícios, referenciando-os com data e nome e dando a sequência cronológica das ações. Todos os tipos de documentos foram reunidos em uma mesma pasta para cada edifício. Dessa maneira foi possível realizar uma aproximação mais aprofundada dos objetos de pesquisa que nos permitiu compreender os procedimentos e a dinâmica das instituições envolvidas. Há que salientar a existência de lacunas na documentação, observada no pouco uso de registros gráficos dos procedimentos adotados nas restaurações, que também seriam elementos importantes para melhor compreensão da dinâmica de trabalho adotada pelos técnicos.

Com a leitura dos documentos, conseguimos definir os entrevistados e desenvolver os questionários. Os entrevistados são os agentes envolvidos diretamente com as atividades de proteção do patrimônio em Paranaguá. As questões se referem à atuação profissional de cada um, elencando certos acontecimentos para que pudéssemos estimular o processo de rememoração de cada entrevistado, muitos de bastidores. E, aproveitando a oportunidade, recolhemos informações sobre outros profissionais envolvidos. No andamento da redação da tese, novas leituras foram realizadas na documentação, procurando identificar os conflitos e contradições presentes nas obras de restauração, mas, principalmente, compreendendo como funcionava o contato entre as personalidades naquilo que estabelecemos como a rede de relações entre as figuraschaves, muito presentes na dinâmica do patrimônio. 
Dessa maneira, os capítulos foram organizados a partir dos monumentos tombados pelo IPHAN, mas que surgem na discussão da rede de relações entre as figuras-chave. O primeiro capítulo traz as iniciativas de preservação em Paranaguá, a partir do tombamento do Colégio Jesuíta em 1937, analisando a atuação de David Carneiro, os contatos estabelecidos por Rodrigo Melo Franco de Andrade com pessoas de diversas regiões do país e o método pelo qual foram conduzidos os primeiros tombamentos pelo recém-criado Serviço do Patrimônio Histórico e Artístico Nacional. Para compreender a preservação do patrimônio em Paranaguá, é essencial considerar o envolvimento do Prof. José Loureiro Fernandes na criação do Museu de Arqueologia e Artes Populares, sediado no antigo Colégio Jesuíta. Essa análise tem por base principal as cartas encontradas nos arquivos do Iphan que relatam a primeira restauração do edifício, mudanças no decorrer das obras, os procedimentos dos técnicos do Iphan e a proposta para o acesso do museu a partir da descoberta das ruínas da antiga igreja jesuíta, encontradas no decorrer das obras.

No segundo capítulo temos os casos das igrejas de São Benedito e Ordem Terceira, que também estiveram sob o foco do Iphan, a partir da década de 1950. Vale salientar que o primeiro pedido de tombamento das duas igrejas se deve à prefeitura de Paranaguá. Mesmo com a iniciativa local, o Iphan não concorda com o tombamento, mas uma década depois houve uma mudança de opinião e as duas igrejas foram tombadas. Essas discussões nos permitem avaliar a condução das atividades do Iphan em Paranaguá e a peculiar história de preservação desses monumentos. A igreja de São Benedito foi restaurada na mesma época que a igreja da Ordem, a primeira obra ficou sob responsabilidade de Cyro Correa Lyra e teve alterações principalmente no espaço interno buscando lhe dar a "feição original". Além dos documentos encontrados nas superintendências do IPHAN, também são essenciais as entrevistas realizadas com Cyro Correa Lyra e José La Pastina, principais envolvidos nas restaurações. $O$ restauro dessa igreja nos apresenta $O$ procedimento dos técnicos do patrimônio, as soluções adotadas na restauração e a discussão sobre a imagem resultante deste monumento. A igreja da Ordem Terceira 
tem uma história peculiar na preservação do patrimônio, uma igreja que foi abandonada no inicio do século XX, incendiada, em seguida reconhecida como patrimônio nacional e foi restaurada tanto pelos técnicos do Iphan, como pelo órgão paranaense de preservação. A igreja foi dessacralizada, teve proposta para tornar-se um museu, foi utilizada como teatro e por fim tornou-se novamente espaço litúrgico. Esse tema é importante na compreensão sobre a dificuldade de novos usos em edifícios antigos e também na discussão sobre as ações de restauro.

O terceiro e último capítulo refere-se ao centro histórico de Paranaguá e os fatos que marcaram a preservação do conjunto até o tombamento federal em 2009. Paranaguá estava inserida nas discussões de preservação do conjunto urbano desde os anos de 1960, sendo a primeira experiência paranaense de delimitação de um conjunto urbano em prol de sua preservação. A análise parte dos monumentos tombados pelo IPHAN em Paranaguá, a preocupação com a ambiência que vai desembocar na primeira proposta de delimitação, analisar de que forma ela influenciou no desenvolvimento de Paranaguá e em seus critérios de preservação que culminaram no ano de 2009 no tombamento federal do centro histórico. 



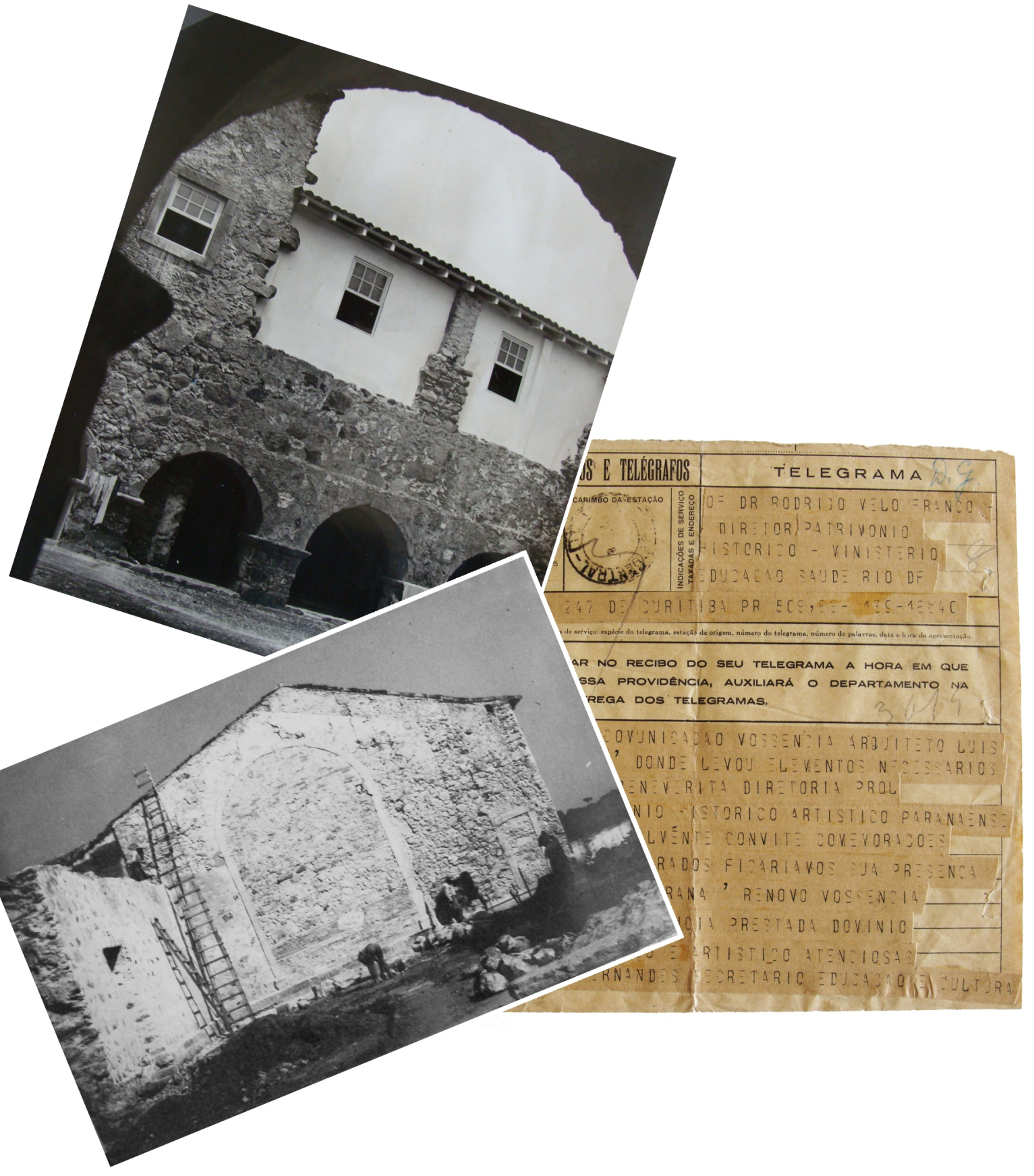





\section{CAPÍtUlo 1 - AS RELAÇões de tRABALHO: RODRIGO MELO FRANCO, JOSÉ LOUREIRO FERNANDES E DAVID CARNEIRO.}

Nesse capítulo analisaremos, a partir das cartas entre Rodrigo Melo Franco de Andrade e José Loureiro Fernandes, como se deram as atividades de restauro do Colégio dos Jesuítas e a formação de um Museu na cidade de Paranaguá. As conversas entre os dois são marcadas pelas atividades de restauração, os atrasos nas obras, as dificuldades em adquirir peças para o museu, entre outros aspectos que traçam um panorama das ações de Loureiro Fernandes e dos técnicos do Patrimônio iniciadas desde os anos 1940. O Colégio dos Jesuítas foi o primeiro edifício tombado nacionalmente em Paranaguá e não devemos nos esquecer do papel de David Carneiro que foi o primeiro contato de Rodrigo Melo Franco no Paraná. Também nessa primeira década de atividades de proteção do patrimônio no litoral paranaense, vale destacar os eventos que culminaram no Tricentenário de Paranaguá, com a presença de autoridades de todo o Brasil, incluindo Luís Saia, que representava o IPHAN, a partir do convite de José Loureiro Fernandes. Nas análises que apresentamos a seguir percebemos que o professor Loureiro é figurachave nas primeiras atividades de preservação, em que temos como pano de fundo a rede de relações entre os representantes e as figuras-chave, são relações estabelecidas durante os anos e que permitiram a vinda dos representantes e técnicos do Serviço do Patrimônio à Paranaguá. 


\section{CAPítulo 1.1 - daVid CARNeiro e o SPHAN: A SELEÇÃo DE OBRAS NOTÁVEIS NO PARANÁ.}

A partir da criação do IPHAN, em 30 de novembro de 1937, Paranaguá teve um exemplar de seu patrimônio recomendado nas esferas de decisão da instituição. Em maio de 1938 houve o tombamento do Colégio dos Jesuítas, imponente edifício setecentista de pedra e cal localizado às margens do rio Itiberê. $O$ monumento obteve registro no livro de tombo Histórico e no de Belas-Artes, quanto à última classificação, vale uma breve análise. Segundo Maria Cecília Londres Fonseca (2009, p. 114):

[...] embora não fosse admitido explicitamente, na prática, o livro Histórico, e também, em certa medida, o Livro Arqueológico, Etnográfico e Paisagístico, terminaram por servir para abrigar aqueles bens que, por falta de maior interesse estético, ou por se acharem adulterados ou parcialmente destruídos, não tinham condições de atender às exigências para inscrição no Livro de Belas-Artes. A autenticidade desses bens era assegurada pela fidedignidade das fontes documentais que atestassem seu valor enquanto documento.

É igualmente importante lembrar que o tombamento do Colégio faz parte dos diálogos estabelecidos entre Rodrigo Melo Franco de Andrade e o historiador paranaense David Carneiro ainda antes da criação do IPHAN ${ }^{4}$. Esta foi a maneira empreendida para a criação das primeiras listagens de edifícios tombados, a partir dos contatos entre o diretor Rodrigo Melo Franco de Andrade e personalidades de diversas regiões do Brasil, o pedido basicamente era o mesmo: a listagem de edifícios civis, religiosos e militares selecionados à partir de um quesito principal: o caráter de excepcionalidade. No Paraná, o diálogo ${ }^{5}$ foi iniciado em março de 1937 quando Rodrigo solicitou ao paranaense o catálogo, as publicações e o histórico do

\footnotetext{
${ }^{4}$ Parte desses diálogos está contida no livro de Marcia Kersten intitulado Os Rituais do Tombamento e a Escrita da História: Bens Tombados no Paraná entre 1938-1990. Curitiba: Editora da UFPR, 2000.

${ }_{5}$ As cartas entre Rodrigo Melo Franco e David Carneiro datam desde 19 de março de 1937 até 16 de julho de 1937, a maior parte delas não foi encontrada nos arquivos do Iphan, encontramos duas cópias na superintendência paranaense. Na superintendência paulista, encontramos duas páginas manuscritas que identificam de forma resumida o diálogo entre David e Rodrigo, o manuscrito não possui autoria nem data, mas nos auxilia na compreensão desse importante contato inicial que culminou nos primeiros tombamentos no Paraná.
} 
Museu Coronel David Carneiro ${ }^{6}$, o que foi respondido em 24 de março enviando ao Rio de Janeiro publicações de sua autoria. David aproveitou para questionar se havia algum delegado nomeado e efetivo do Patrimônio Histórico e Artístico naquela região, alegando ser a única pessoa que poderia responder por tal cargo. Em resposta sobre a nomeação de delegado, Rodrigo explica que "não puderam ser definidas a pessoa alguma" e que o Paraná estaria inserido na $7^{a}$ Região, com sede em Porto Alegre, sendo que o delegado "deverá residir efetivamente na capital riograndense" nesta carta, datada de 5 de abril ${ }^{7}$, Rodrigo consulta-o sobre a "possibilidade de tomar a si o encargo de relacionar as obras de arquitetura civil, religiosa e militar existentes no Paraná e que possam ser consideradas de excepcional valor artístico ou histórico."

David Carneiro pertencia a uma família ligada ao comércio da Erva-Mate, seu avô teve negócios associados ao Barão do Serro Azul e participou da Revolução Federalista em fins do século XIX, seu pai foi um conhecido industrial em Curitiba também ligado ao beneficiamento da Erva-Mate. David tem forte influência das escolas militares, era um dos divulgadores da filosofia Positivista e estudou no Colégio Militar do Rio de Janeiro entre 1919 a 1922, posteriormente cursou Engenharia Civil na Universidade do Paraná. Suas pesquisas envolviam a história do Paraná, publicando livros relativos a Revolução Federalista e ao Cerco da Lapa. Como colecionador, reuniu ao longo dos anos um extenso acervo de peças militares que se tornou uma das maiores coleções particulares do país. (MACHADO, 2012). Não sabemos precisar sobre contatos e aproximações anteriores, mas é possível que o perfil de David Carneiro e a fama de sua coleção tenham chamado a atenção de Rodrigo Melo Franco e motivado os primeiros contatos estabelecidos com vistas à preservação do patrimônio paranaense.

É importante salientar que apesar do pleito de Carneiro e a indefinição sobre o titular, o diretor Rodrigo Melo Franco fez o convite em abril de 1937 para

\footnotetext{
${ }^{6}$ O Museu Histórico Coronel David Carneiro foi fundado em 1928 e foi uma homenagem ao pai de David Carneiro, industrial. A extensa coleção de peças possui desde armas, uniformes, cristais e etc. que contam parte da história do Paraná e principalmente da Revolução Federalista.

${ }^{7}$ Carta de Rodrigo Melo Franco a David Carneiro em 5 de abril de 1937 (Arquivo do IPHAN-PR).
} 
Augusto Meyer, diretor da Biblioteca Pública do Estado do Rio Grande do Sul e que possuía boas relações com o presidente Getúlio Vargas, para tornar-se representante do órgão na região e também solicitou-lhe a listagem de bibliografia e imagens de obras de arquitetura civil e religiosa do Estado. ${ }^{8}$ Da mesma maneira houve o pedido da listagem das obras à Mário de Andrade, em maio de 1937, referentes ao Estado de São Paulo. Em carta Rodrigo explica suas intenções:

O que lhe peço é apenas um inventário preliminar, com os seguintes dados a respeito de cada edificação a relacionar: descrição sumária, histórico breve, autoria da obra (quando for possível apurá-la), material empregado na construção (cantaria, taipa ou o que for), estado atual de conservação, reforma ou alterações que tiver sofrido, reparos urgentes de que precisar, referências bibliográficas que existirem a seu respeito e, por fim, documentação fotográfica (esta última tão completa quanto possível) (ANDRADE, 1987, p.125)

Assim, constatamos que o ano de 1937 foi marcado pelo contato de Rodrigo com diversas personalidades dos Estados, antes mesmo da oficialização da instituição ${ }^{9}$, solicitando informações e fotografias de obras arquitetônicas religiosas e civis que pudessem fazer parte do rol de bens e monumentos reconhecidos pelo órgão em constituição. Apesar de tal procedimento parecer uma estratégia descentralizada, na verdade era apenas uma mera consulta, pois as decisões eram efetivamente centralizadas no Rio de Janeiro, onde se reuniam os principais nomes da fase inicial da instituição, como o próprio Rodrigo Melo Franco, Lucio Costa e Carlos Drummond de Andrade, denominados por Mariza Santos de Academia SPHAN $^{10}$. Ficam evidentes a hierarquização das atividades e o controle através das correspondências aos representantes regionais, demonstrando que as decisões finais estavam a cabo de poucas pessoas detentoras do discurso oficial. (CHUVA, 2009).

\footnotetext{
8 Parte das cartas entre Rodrigo Melo Franco e o jornalista Augusto Meyer é discutido na pesquisa de mestrado intitulada Patrimônio em prosa e verso: a correspondência de Rodrigo Melo Franco de Andrade para Augusto Meyer, de Laura Regina Xavier.

${ }^{9} \mathrm{O}$ anteprojeto para a criação do IPHAN elaborado por Mário de Andrade é de março de 1936, a instituição era denominada Serviço do Patrimônio Artístico Nacional (SPAN). No mesmo ano, o presidente Vargas autorizou, em caráter experimental, o funcionamento do Serviço do Patrimônio Histórico e Artístico Nacional com direção de Rodrigo Melo Franco de Andrade. (CUNHA, 2010).

10 "O fato é que a Academia SPHAN nasce ancorada numa ideia básica que é o registro da nação, cuja face era preciso tornar visível; não através da incorporação de traços da natureza, como no romantismo, mas através da identificação de uma tradição cultural que tivesse uma duração no tempo, cujo passado era preciso alcançar, e que tivesse uma visibilidade no espaço, cuja configuração e moldura era preciso estabelecer”. (SANTOS, 1996, p. 78).
} 
Essa centralidade também é observada por Cínthia Nigro (2003, p. 167):

As primeiras instituições oficiais de preservação do patrimônio em vários países do mundo ocidental e, inclusive, no Brasil se estabeleceram a partir de um modelo centralizado de gestão, que revestiu os bens culturais de um forte caráter patriótico, sagrado, prestigioso, exclusivista e elitista, relativo ao universo de bens materiais etc.

Em 8 de abril de $1937^{11}$, David Carneiro enviou à Rodrigo a listagem solicitada, alegando que, no Paraná, são poucas as obras com excepcional valor artístico e histórico (Figura 1).

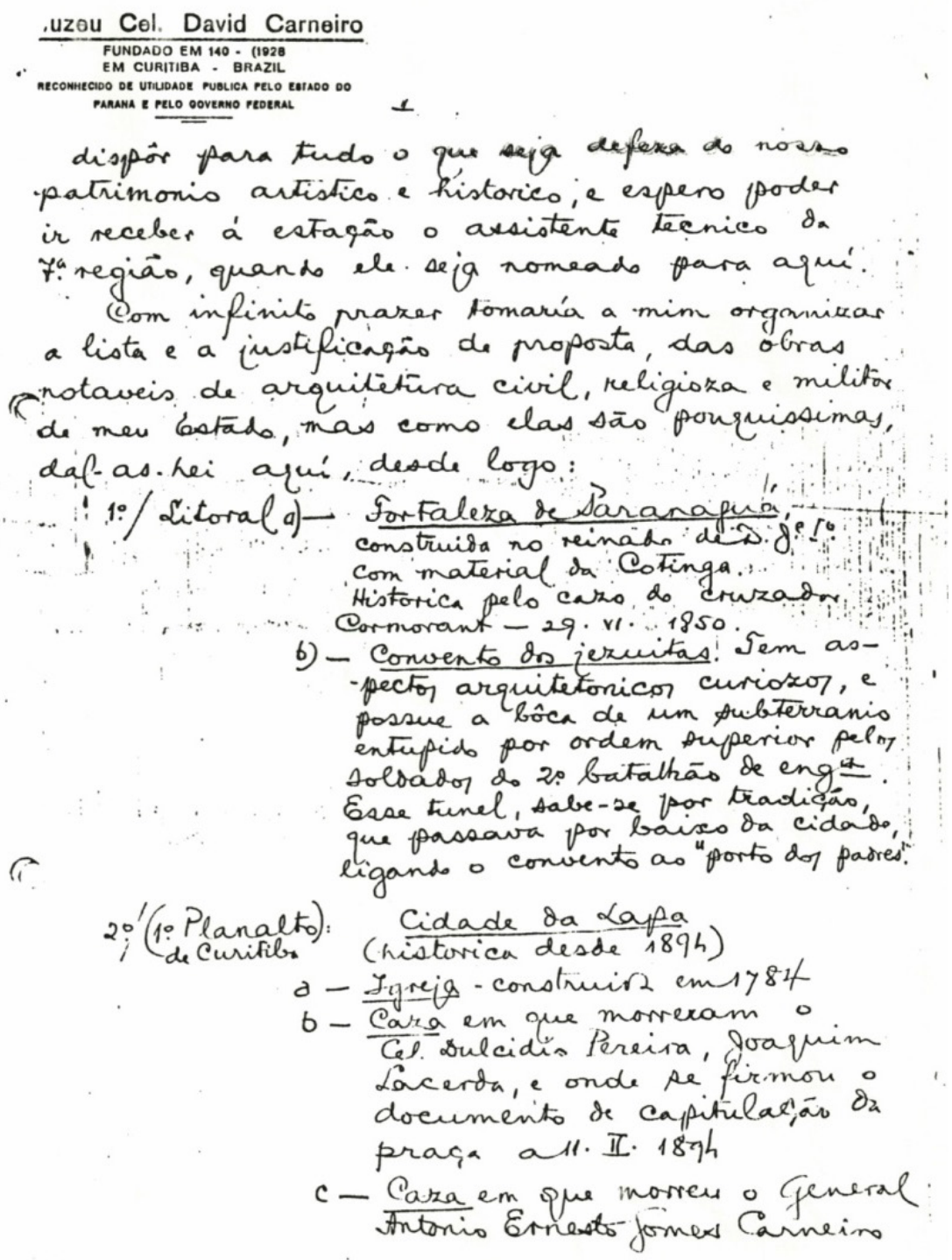

${ }^{11}$ Carta de David Carneiro a Rodrigo Melo Franco em 8 de abril de 1937. (IPHAN-PR) 


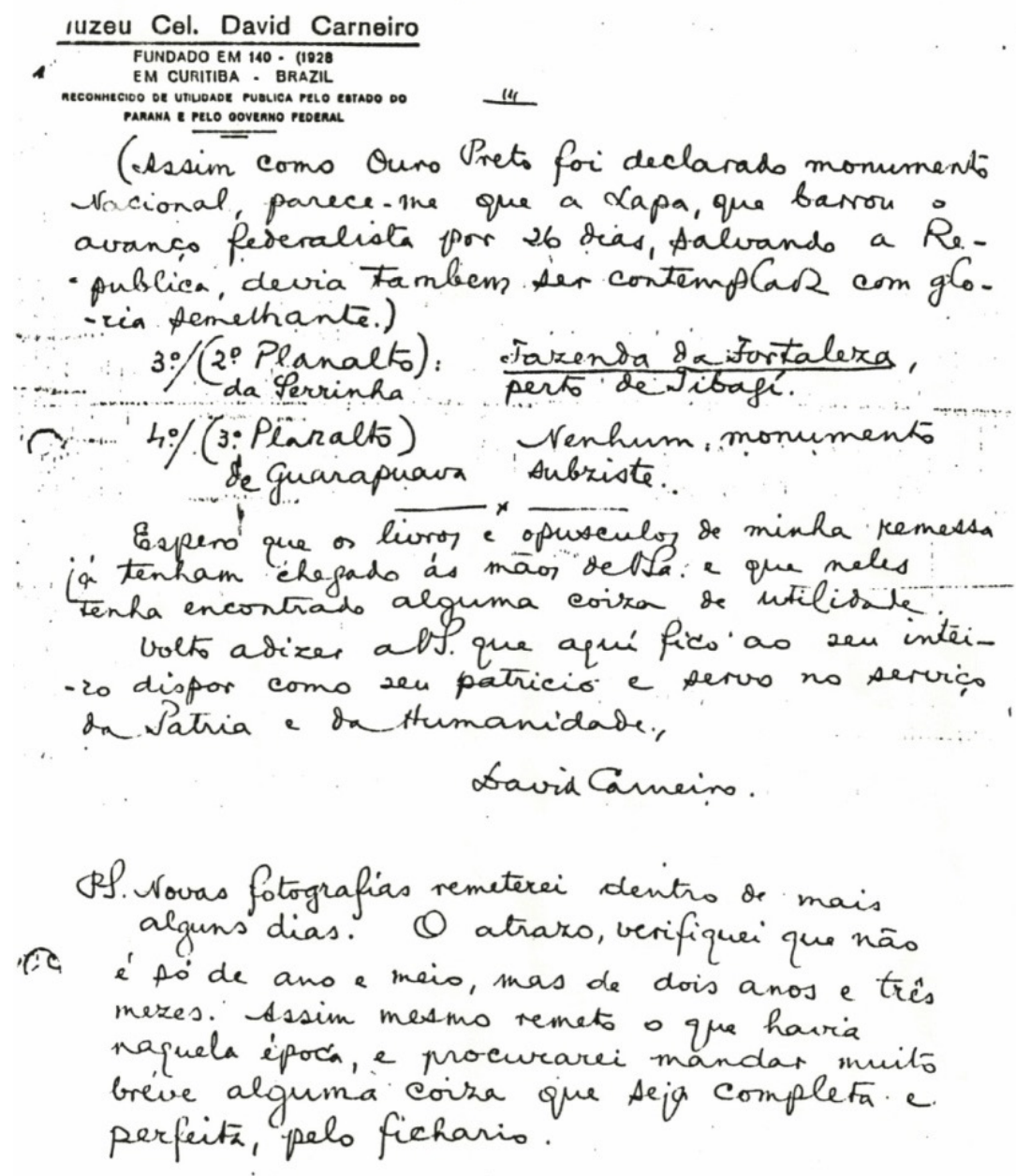

Figura 1: Páginas da carta de David Carneiro enviada a Rodrigo Melo Franco de Andrade, em abril de 1937, em que está contida a sugestão dos bens a serem tombados no Paraná.

Fonte: Arquivo do Iphan Paraná

A divisão por planaltos foi baseada na classificação dos relevos do Estado do Paraná estabelecida por Reinhard Maack ${ }^{12}$. No litoral foi inclú́do o Colégio dos Jesuítas como monumento destacando ter "aspectos arquitetônicos curiosos" e possuir "a boca de um subterrâneo entupido por ordem superior pelos soldados do $2^{\circ}$ Batalhão de Engenharia". ${ }^{13}$ De maneira geral, não foram muitas obras selecionadas por David e deduzimos que aquelas listadas já eram de conhecimento do paranaense, uma vez que a carta de Rodrigo foi respondida num intervalo de poucos dias. Ao contrário de Mario de Andrade, por exemplo, que realizou viagens

\footnotetext{
12 Maack em seu livro Geografia Física do estado do Paraná estabeleceu a classificação do relevo paranaense em quatro grandes domínios: Litoral; Primeiro Planalto (Planalto de Curitiba, Segundo Planalto (Planalto de Ponta Grossa) e Terceiro Planalto (Planalto de Guarapuava).

13 Carneiro traz a informação de que o túnel deveria atravessar toda a cidade, ligando o Convento ao "Porto dos padres". Trabalhos posteriores de prospecção comprovariam a inexistência de tal ligação
} 
pelo interior de São Paulo e preparou o relatório após cinco meses de estudos. Segundo Cristiane Gonçalves (2007, p. 53):

Nesse primeiro levantamento, foram mapeados mais de quarenta exemplares de edifícios religiosos, entre eles a Igreja de São Miguel, em São Paulo; a capela de Santo Antônio, em São Roque; a Matriz de São Luiz do Paraitinga e a de Santana do Parnaíba; a Capela do Pilar, em Taubaté; pouco mais de uma dezena de casas de cadeias e fortes, no litoral; e pouquíssimos exemplares de arquitetura civil, visivelmente menos detalhados. Aparecem ainda listados os conjuntos urbanos de Iguape e Cananéia.

A rede estabelecida pelos contatos também estava presente em outros Estados brasileiros, isso foi reportado por Rodrigo em carta a Mário em 17 de maio de 1937(ANDRADE, 1987, p.126):

Estou providenciando ativamente para intensificar também os trabalhos na Paraíba, em Pernambuco, Bahia, Minas, Paraná, Rio Grande do Sul e aqui no Distrito Federal, a fim de que, ao terminar o primeiro semestre do ano, já tenhamos um inventário apreciável do patrimônio histórico e artístico nacional em matéria de arquitetura. Do que há de mais importante faltarão apenas dados sobre o Maranhão e o estado do Rio, que procurarei coligir no segundo semestre, juntamente com os relativos aos outros estados de patrimônio mais pobre.

Apesar de instruir pelas cartas os itens que deveriam conter nos inventários solicitados por Rodrigo, cada relatório foi organizado de uma maneira, Mário de Andrade enviou um relatório mais detalhado, enquanto David uma carta de três páginas. Essa diferença dos inventários dos monumentos, produzido pelos contatos de Rodrigo pode ter sido o motivo que levou a Instituição desenvolver um modelo de ficha padrão que seria preenchido com os critérios já préestabelecidos. Poucas informações são encontradas sobre o envio das fichas e sua elaboração, sabemos que Rodrigo enviou a Mário de Andrade em 26 de junho de 1937“[...] sob registro, 50 fichas destinadas ao tombamento de arquitetura nesse estado.”(ANDRADE, 1987, p.132). Também foram enviadas 30 fichas a Augusto Meyer na mesma data, destinadas ao tombamento ${ }^{14}$. São as únicas evidências encontradas sobre o envio das fichas, se desconhece a iniciativa de elaboração desse

\footnotetext{
14 A transcrição da carta de Rodrigo Melo Franco de Andrade a Augusto Meyer consta na dissertação de Laura Regina Xavier.
} 
documento, ou se estes foram baseados em outras experiências do gênero, no entanto, podemos afirmar que foi a primeira tentativa do IPHAN em sistematizar a inventariação dos monumentos.

As fichas preenchidas por David Carneiro estão guardadas no Arquivo Central do Rio de Janeiro. Elas contêm itens que deveriam ser preenchidos e assinados pelo "encarregado do tombamento", os itens eram: designação, autoria, época, situação, proprietário, referências, observações, esquema ou fotografia e caracteres descritivos. A relação de fichas enviadas por David Carneiro difere da primeira listagem de 1937, pois o número de bens sugeridos em Paranaguá foi ampliado. Nas fichas foram catalogados: o Colégio dos Jesuítas (Figura 2), o Palacete Visconde de Nácar (Figura 3), a Fortaleza de Paranaguá, a Igreja Matriz, a Igreja da Ordem Terceira de São Francisco das Chagas e a Igreja de São Benedito.

Analisando as fichas parnanguaras, dos seis monumentos apontados apenas um é do século XIX, o Palacete Visconde de Nácar, edifício de predominância neoclássica. A justificativa apresentada na ficha motiva-se pela importância histórica do edifício, pois abrigou D. Pedro II e a Princesa Izabel no início das obras e na inauguração da ferrovia Paranaguá-Curitiba. Quanto aos outros monumentos, baseando-se nos estudos de Ricardo Severo, David justificou a manutenção do "puro estilo colonial". Apesar de não estar claro nas cartas emitidas por Rodrigo sobre a escolha dos monumentos, havia a consonância dos colaboradores com as ideias do grupo de intelectuais do Serviço, primando pelas obras oitocentistas.

Isso se deve às viagens empreendidas pelos intelectuais à Minas Gerais, vale citar Alceu Amoroso Lima(1893-1983) e Rodrigo Melo Franco de Andrade em 1916 e a viagem de Lucio Costa (1902-1998) à Diamantina na década de 1920, não esquecendo dos estudos de Ricardo Severo e José Wasth Rodrigues (1891-1957) sobre a arquitetura colonial, suas conferências e a propagação dos estudos sobre o tema no Brasil. (FONSECA, 2009).

Apesar de Rodrigo nas cartas, definir as fichas como destinadas ao tombamento, seu preenchimento não garantia a classificação nas listagens, portanto 
no caso de Paranaguá foi aprovado apenas o tombamento do Colégio dos Jesuítas e a Fortaleza da Ilha do Mel. Os monumentos estão contidos numa lista de 29 de março de $1938^{15}$ que agrupou edifícios de outros Estados classificando-os nos livros de Tombo Histórico e de Belas-Artes, dentre os quais estão a Praça XV, o Palácio do Catete e a Casa de Ruy Barbosa no Rio de Janeiro e as fortalezas nos Estados da Bahia e do Pernambuco.
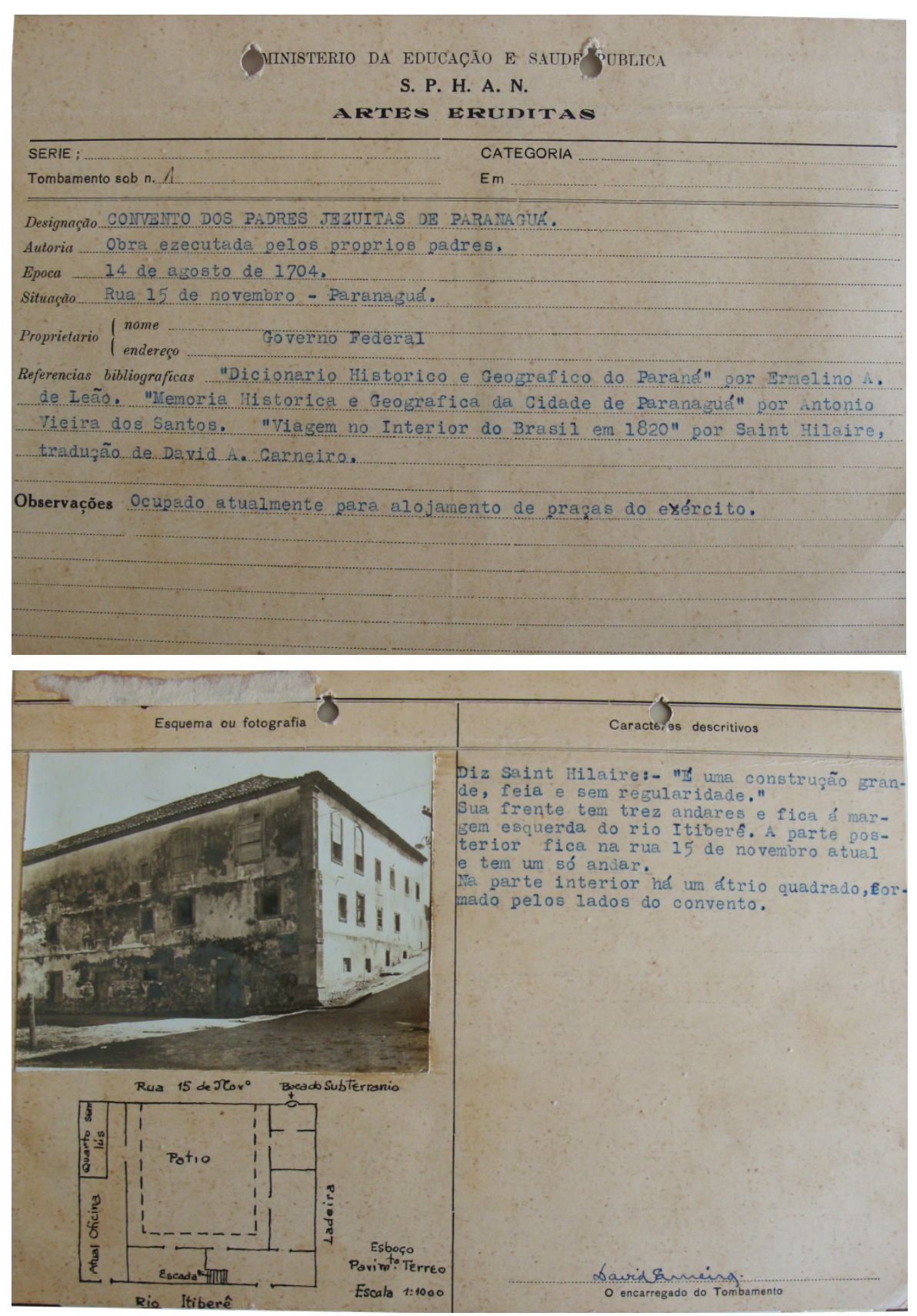

Figura 2: Fichas do SPHAN preenchidas por David Carneiro, provavelmente em 1937, com os dados do antigo Convento Jesuíta. Fonte: Arquivo Central IPHAN

\footnotetext{
${ }^{15}$ Notificação de tombamento de 29 de março de 1938. (Arquivo Central).
} 


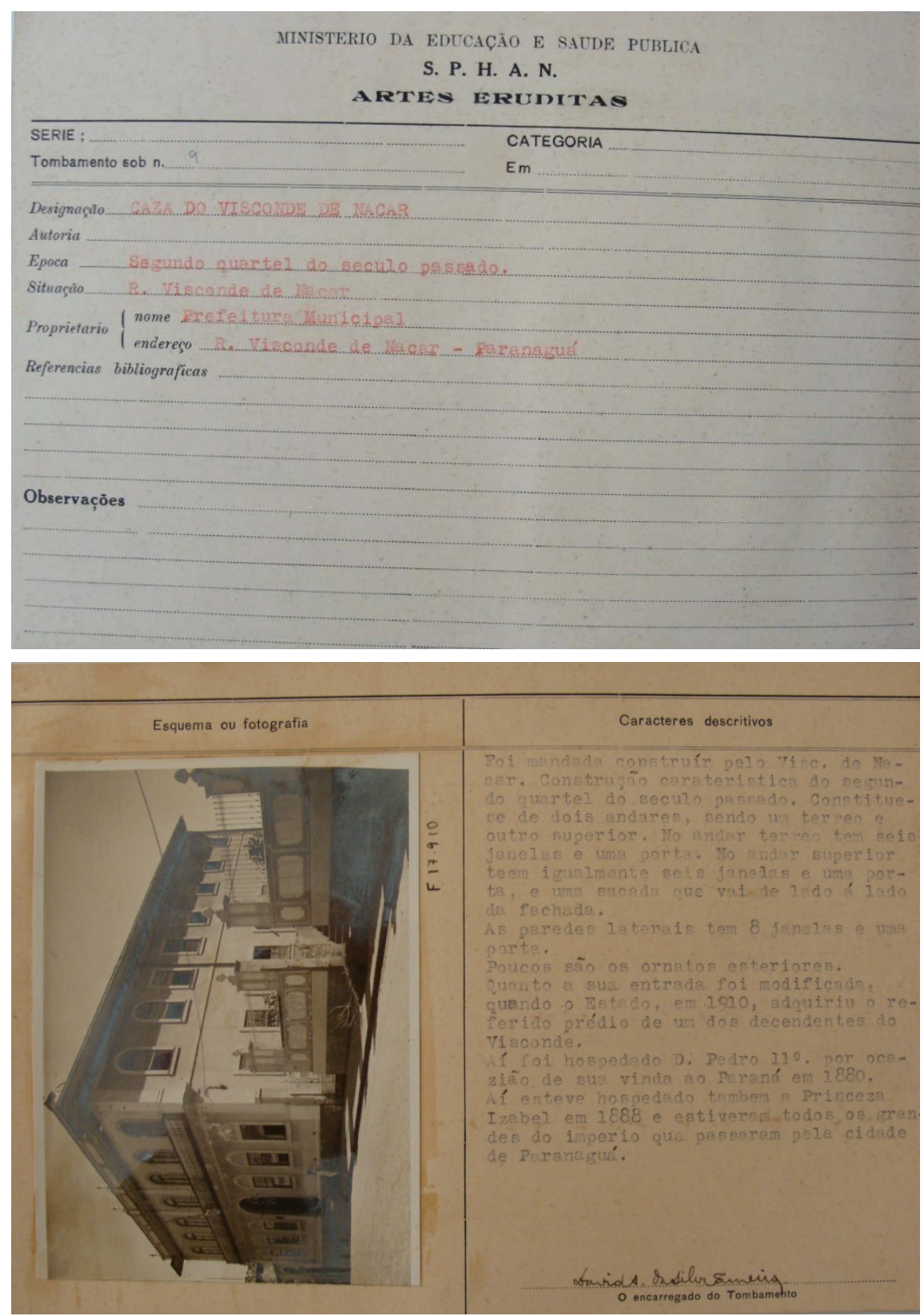

Figura 3: Fichas do Sphan preenchidas por David Carneiro com os dados do Palacete Visconde de Nácar. Fonte: Arquivo Central IPHAN

O primeiro ano de atuação oficial do Iphan, 1937, é dominado pela organização da instituição, que se deu a partir da criação das Diretorias Regionais e a coleta de material fotográfico e documental daquilo que as personalidades da rede de contatos de Rodrigo Melo Franco de Andrade selecionaram e enviaram à direção carioca. As diretorias foram organizadas e os seus representantes selecionados por Rodrigo a partir da rede estabelecida anos antes. A primeira proposta de organização administrativa do então Serviço do Patrimônio Histórico Nacional foi definida pelo decreto n³78 de 13 de janeiro de 1937 que criou e organizou o Ministério de Educação e Saúde e dividiu sua administração em oito 
regiões, que são as mesmas regiões de atuação do IPHAN, o Paraná ficou na $7^{a}$ Região em conjunto com Santa Catarina, sob jurisdição do Rio Grande do Sul ${ }^{16}$ (Figura 4).

Em relação à administração das regionais, explica Márcia Chuva (p. 62, 2009):

Essas últimas foram se constituindo gradativamente, de forma não muito regular, tendo algumas existindo por curto espaço de tempo, ao longo do período. Aquelas que se firmaram desde os anos iniciais, e cujos representantes fizeram longa carreira no SPHAN, tinham suas sedes nas capitais dos estados da Bahia, de Pernambuco, de São Paulo e de Minas Gerais.

A bibliografia sobre o tema não esclarece a maneira pela qual as regionais foram organizadas administrativamente e quais realmente funcionaram entre 1937 a 1946. No caso do Paraná, nos raros documentos desse período, não constam contatos com a sede gaúcha, apenas diretamente com a central carioca, o que se sabe é que Augusto Meyer, preterido para as funções de delegado da $7^{a}$ Região, esteve poucos meses no cargo se afastando definitivamente das atividades do IPHAN para assumir a presidência do Instituto Nacional do Livro no início de 1938, Rodrigo Melo Franco então nomeou David Carneiro ${ }^{17}$, que provavelmente ficou nesta função até as mudanças administrativas na instituição em 1946.

A partir de um novo decreto, no 8534 de 2 de janeiro de 1946, a instituição passou a ser denominada Diretoria do Patrimônio Histórico e Artístico Nacional e as regionais, das 8 criadas no primeiro decreto, reduzem-se a 4 distritos: $1^{\circ}$ Distrito - Recife (atuação no Rio Grande do Norte, na Paraíba, no Pernambuco e nas Alagoas); $2^{\circ}$ Distrito - Salvador (atuação na Bahia e no Sergipe); $3^{\circ}$ Distrito - Belo Horizonte (atuação em Minas Gerais) e por fim o $4^{\circ}$ Distrito - São Paulo (atuação em São Paulo, no Paraná, em Santa Catarina e no Rio Grande do Sul) (Figura 5). No mesmo decreto foram estabelecidas as funções e a organização da Diretoria: a

\footnotetext{
${ }^{16}$ Sobre a organização inicial da Secretaria, a carta de Rodrigo Melo Franco de Andrade a David Carneiro em 5 de abril de 1937 confirma esta informação: "Em verdade, para os efeitos da administração dos serviços do Ministério da Educação, a que esta repartição está subordinada, esse Estado consitue parte integrante da $7^{a}$ Região, cuja sede é em Porto Alegre." (Acervo Iphan - Pr)

17 Em carta de 29 de janeiro de 1938, Rodrigo Melo Franco solicita a Augusto Meyer a entrega de todo o arquivo da Região para David Carneiro, o novo delegado da $7^{\text {a }}$ Regional. Ver (XAVIER, 2008, p.126).
} 
sede geral, no Rio de Janeiro, era composta pelo Diretor Geral e duas divisões administrativas, a Divisão de Estudos e Tombamento composta pela Seção de Arte e a Seção de História; e a Divisão de Conservação e Restauração composta pela Seção de Projetos e pela Seção de Obras (Figura 6).

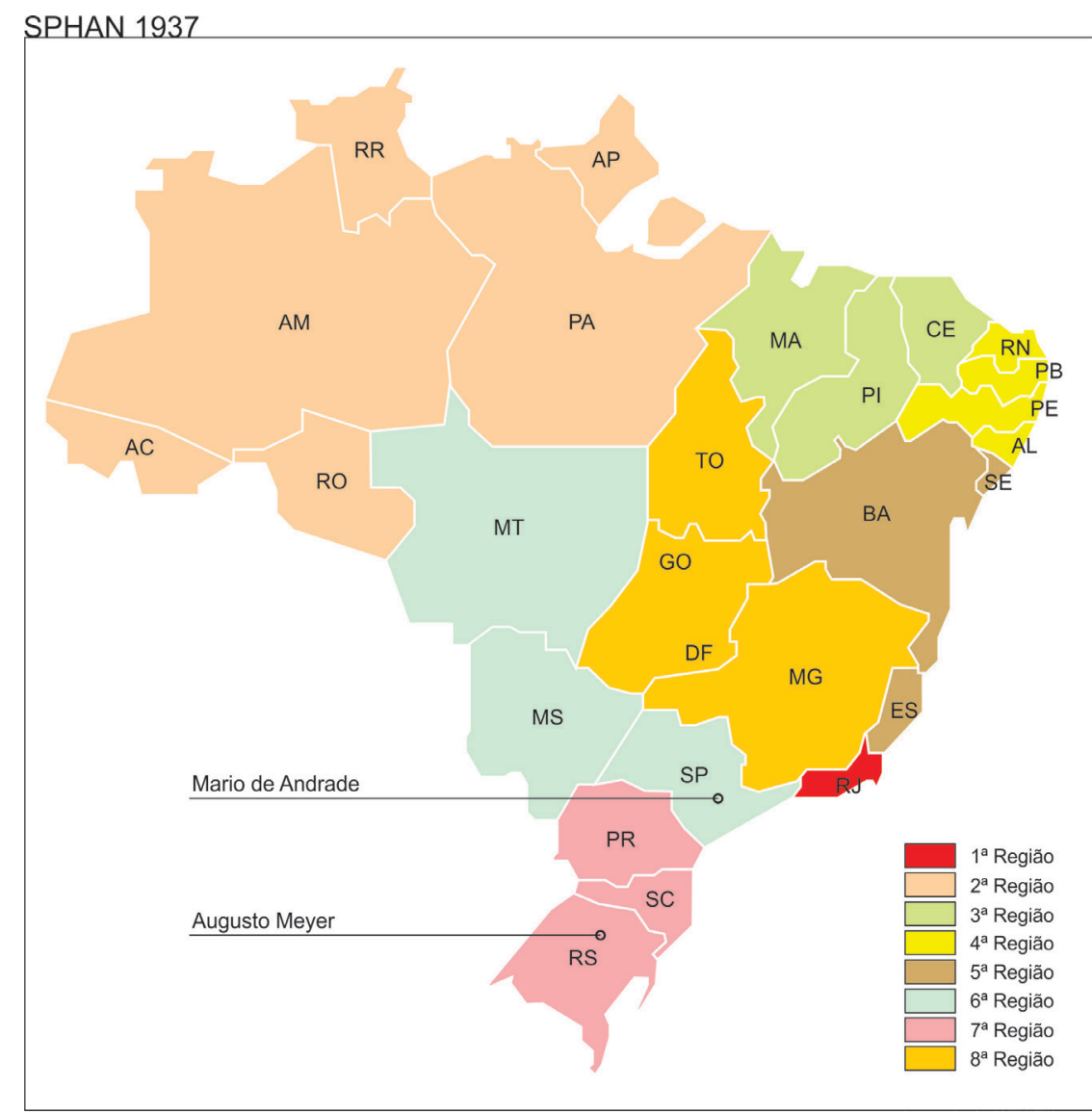

Figura 4: Regionais estabelecidas pelo decreto n³78 de 13 de janeiro de 1937

Fonte: Elaborado pelo autor, 2014.

Por que os Estados do Paraná e de São Paulo, que não eram apontados como regiões privilegiadas em "monumentos de caráter excepcional", estão presentes nas primeiras listas de bens tombados em 1938 juntamente com Minas Gerais e Rio de Janeiro? Parte desta indagação pode ser respondida pela rede de contatos estabelecida por Rodrigo Melo Franco de Andrade. Este conjunto de fragmentos, como bem define José Reginaldo Gonçalves, não são apenas resultado de uma seleção que primava pelo caráter de excepcionalidade e originalidade, mas também de outras influências que podem ser compreendidas no campo das relações sociais. O Paraná foi incluído nas listas porque havia a insistência e o 
interesse de David Carneiro e São Paulo pela personalidade, influência e dedicação de Mário de Andrade. Portanto:

Nesse sentido, o patrimônio é uma vasta coleção de fragmentos, na medida em que seus componentes são descontextualizados, retirados dos seus contextos originais, no passado ou no presente, e reclassificados nas categorias das ideologias culturais que informam as políticas oficiais de patrimônio. (GONÇALVES, 1996, p.112).

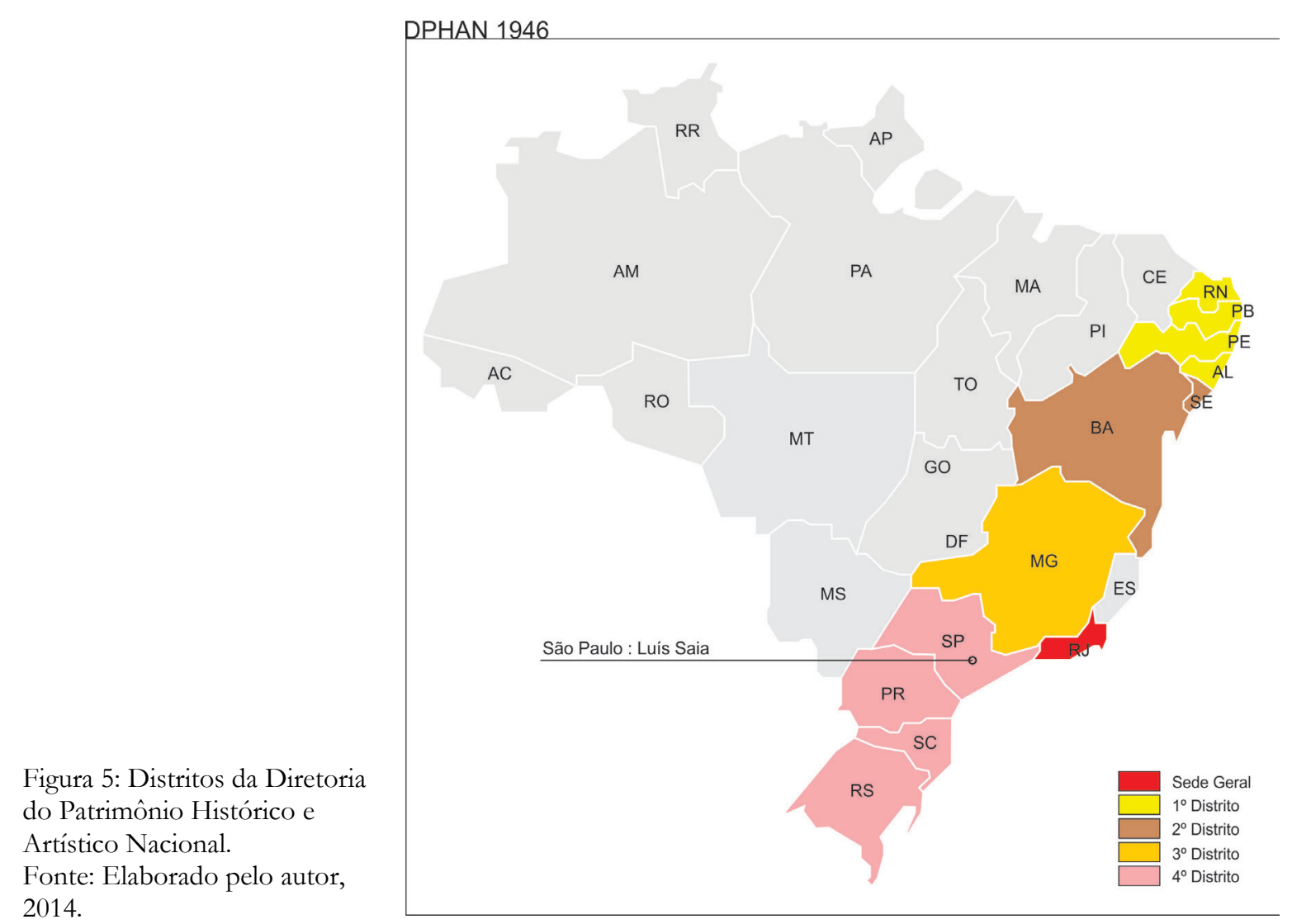
2014.

Figura 6: Organização da Sede Geral da Diretoria do Patrimônio Histórico e Artístico Nacional. Fonte: Elaborado pelo autor, 2014.

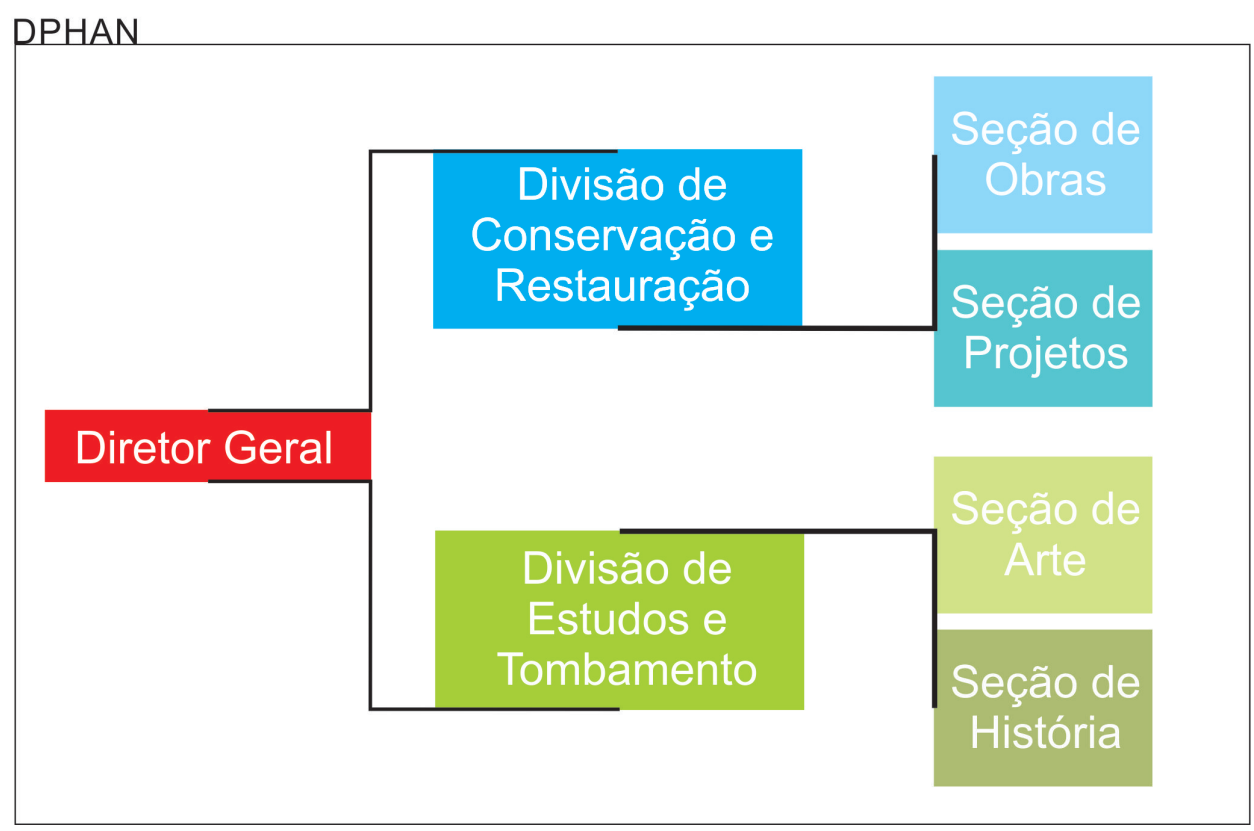


Nesse contexto está claro que o primeiro ano de atuação do IPHAN ocorreu a partir das redes de informação existentes em diversos Estados brasileiros, que se deu pelos contatos afinados com os ideais promovidos pelo grupo de intelectuais que organizava a nova instituição. Uma rede que se ampliou a partir das inúmeras obras de restauração pelo país, e em Paranaguá isso foi evidente com as obras do Colégio dos Jesuítas, em que se estabeleceram intensas comunicações, majoritariamente entre os envolvidos no Paraná e na Central carioca, do que no $4^{\circ}$ Distrito paulista.

Esta rede foi constituída a partir de um campo de tensões que se estabeleceu em função de um interesse comum de forte motivação: a classificação de um conjunto de bens arquitetônicos considerados representativos da cultura nacional. Esta demanda foi centralizada pela direção da instituição na capital federal, o Rio de Janeiro, principalmente no papel desempenhado por seu primeiro diretor, Rodrigo Melo Franco de Andrade. Nesta rede, havia uma visível hierarquia rigidamente apoiada nos cargos criados para a formação do IPHAN, quando foram solidificadas as interações entre as personalidades envolvidas, resultando em “[...] um conjunto de relações de forças objetivas impostas a todos os que entrem nesse campo e irredutíveis às intenções dos agentes individuais ou mesmos às intenções diretas entre os agentes." BORDIEU (1989, p. 134). Isso pode ser constatado nas análises das restaurações, conflitos e demais necessidades impostas pelas obras e ações empreendidas pela instituição. Vale destacar que esta rede se construiu obedecendo a profundas afinidades de interesses culturais e pessoais preexistentes: em geral composta por intelectuais ou personalidades que já se dedicavam a temas relativos à história de seus Estados, como David Carneiro, um grande entusiasta da cultura paranaense.

Este patrimônio, nos primeiros anos de atuação do IPHAN, foi constituído a partir das fotografias, fichas e inventários produzidos pelas personalidades em seus Estados e posteriormente analisados e selecionados pelos técnicos da Central carioca. A fotografia foi essencial para os trabalhos de inventário, Lucio Costa em 
seu texto sobre o Plano de Trabalho Para a Divisão de Estudos e Tombamento da $D P H A N$ de 1949, apontava para a necessidade de cursos e aparelhos fotográficos em cada Distrito:

Além disso, cada distrito deverá possuir um aparelho Leica, ou similar, completo, e contratar com fotógrafo competente um curso prático de fotografia com o propósito de fazer de cada um dos funcionários técnicos da repartição um fotógrafo habilitado, capaz de fazer a sua própria documentação nas viagens de reconhecimento, pesquisa ou inspeção. (PESSÔA, 2004, p.87)

O ideário do patrimônio nacional se constrói a partir dessa centralização, que decidia e classificava aquilo que era considerado parte do conjunto que representava o passado nacional. Ou seja, a partir desses monumentos foi possível construir o que Néstor Canclini (1994) aponta como uma unidade e coerência imaginária, que se forma a partir dos discursos e análises elaborados principalmente pelos intelectuais da área de arquitetura. São os discursos que tornam o monumento inserido num contexto histórico e artístico de caráter nacional, e Rodrigo Melo Franco em seus discursos insere os bens que integram o patrimônio dentro de uma totalidade que supostamente era integrada e contínua. (GONÇALVES, 1996).

O caso do Colégio Jesuíta de Paranaguá nos traz as justificativas que levaram ao seu tombamento, inserindo-o dentro da história da ocupação dos padres e sua atuação no contexto brasileiro. A partir do diálogo estabelecido entre os representantes paranaenses, a Central carioca e a Diretoria paulista, são analisados e discutidos os conflitos e as contradições que marcaram as primeiras obras de restauração deste edifício e que se torna um exemplo da atuação do IPHAN em Estados sem distrito próprio, ou seja, subordinados à outros Estados 


\subsection{RODRIGo MELo fRANCo de ANDRADE E JOSÉ LOUREIRO FERNANDES: O COLÉGIO DOS JESUÍTAS}

O Colégio dos Jesuítas é de fato, um importante exemplar nas discussões sobre as práticas da preservação do patrimônio histórico nacional nas primeiras décadas de atuação do IPHAN, pois vai ao encontro com nossa tese sobre a atuação das figuras-chave e do modus nas operações de restauro empreendidas neste edifício setecentista. Isso é verificado fundamentalmente pelas cartas entre Rodrigo Melo Franco de Andrade e José Loureiro Fernandes, que revelam as discordâncias entre as instâncias de preservação e a maneira pela qual as práticas de intervenção foram adotadas pelos técnicos. Ora, não devemos nos esquecer da grande responsabilidade do ato da restauração, que pode alterar definitivamente as características de um monumento e influenciar em situações ligadas à memória coletiva. A adição de elementos que possuem uma significância que vai além do objeto, como por exemplo, na instalação de grades de proteção no antigo Colégio para sua adaptação ao museu, acabou despertando na população as memórias das antigas prisões. ${ }^{18}$

Neste subcapítulo, apresentamos algumas das práticas empreendidas pelos técnicos do IPHAN no Colégio Jesuíta com a finalidade de adaptá-lo ao Museu de Arqueologia e Etnografia: da alteração de vãos, ao uso do concreto armado, da criação de uma ruína na readequação do novo acesso ao Museu e da proposta para a instalação de uma placa indicativa. Estas discussões nos direcionam sobre os procedimentos dos técnicos, que não podemos afirmar que seguiam alguma vertente teórica predominante da disciplina de restauração e que acarretou na falta de coerência e contradições destas atividades em Paranaguá.

O estado em que se encontrava o antigo Colégio dos Jesuítas, após o tombamento em 1938, era crítico. O edifício naquele período funcionava como

\footnotetext{
18 De fato existiram instalações prisionais no antigo Colégio no período em que funcionou a Guarda Nacional, mas a instalação de grades no pavimento térreo foi por questões de segurança, item que preocupava José Loureiro Fernandes. (FURTADO, 2006).
} 
alojamento de soldados do exército e prisão, mas décadas antes foi a sede da Alfândega de Paranaguá. Em 1939 os jornais noticiavam a possibilidade de pesquisas no monumento na finalidade de desvendar um possível túnel que levaria até a área portuária da cidade, na Baía de Paranaguá. Jornais curitibanos publicaram notícias sobre o interesse de David Carneiro pelas pesquisas e pela restauração desse túnel, elemento que também foi citado em suas fichas para o IPHAN:

O dr. Daví Carneiro (sic), Delegado do Patrimônio Artístico neste Estado, vai entrar em entendimento com o dr. Rogério de Melo Franco (sic), para lhe solicitar autorização afim de promover pesquisas em torno do subterrâneo do Colegio.

Aquele nosso conterrâneo si receber permissão, promoverá o desvendamento definitivo do mistério que rodeia há perto de 200 anos aquele próprio. (DIARIO DA TARDE, 1939)

David Carneiro estudou profundamente o Colégio, em 1940 produziu desenhos do claustro e plantas dos pavimentos (Figura 7), neste mesmo ano o resultado de suas pesquisas foi publicado no quarto número da Revista do SPHAN, intitulado Colégio dos Jesuitas em Paranaguá. O texto apresenta o histórico deste edifício, desde a chegada dos Jesuítas à Paranaguá, a construção do Colégio e a expulsão dos padres pelo Marquês de Pombal, sem esquecer as alegorias que envolveram a história da Companhia de Jesus no Brasil, como no caso do túnel secreto. De acordo com o autor, o Colégio caracteriza-se pela simplicidade e austeridade, o texto apresenta de forma clara a importância histórica desta construção e não de sua arquitetura:

Por outro lado o claustro interior, a bica, o algibe e as arcadas e os capitéis mostram um gosto sui generis dentro da pobreza do edifício que evidenciam não ser possível culpar os arquitetos jesuítas da falta de gosto artístico, notada por Saint-Hilaire na construção de Paranaguá (CARNEIRO, 1940, p. 382)

Apesar de seu texto destacar apenas o valor histórico, o tombamento de 1938 também se refere à suas qualidades arquitetônicas, de modo que está registrado no livro de Belas-Artes, neste aspecto percebemos uma pequena 
contradição: Estaria David em desacordo com a decisão do IPHAN? A questão é que o autor utilizou a visão de um europeu, Saint-Hilaire, sobre o edifício e que corroborou na definição de seu juízo de valor, vide que na primeira ficha de tombamento, elaborada por David, há uma citação do viajante sobre a "feiura" do velho Colégio.

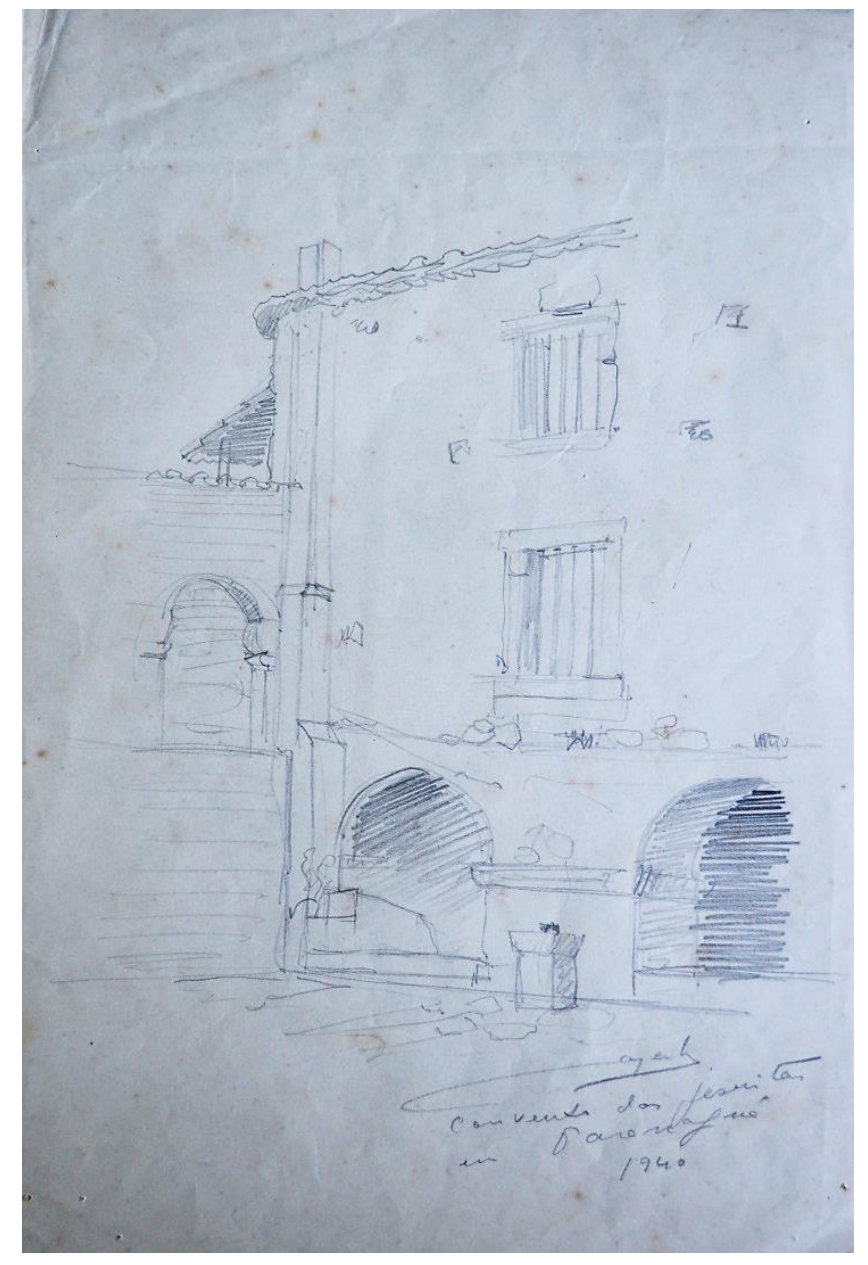

Figura 7: Desenhos de David Carneiro do antigo Convento Jesuíta apresentando o claustro. Fonte: Acervo IPHAN-PR.

Dando continuidade a esta fase de levantamentos que marcaram os primeiros anos, em 1940 foi à Paranaguá Erich Hess, um dos principais fotógrafos do IPHAN. Consideramos como a primeira visita de um representante da instituição recém-formada a Paranaguá. Pelos documentos pesquisados, apenas Hess foi à Paranaguá naquele ano, sua função era fotografar o que havia de interesse para o IPHAN na cidade e dessa forma ampliar o número de imagens de edificações que fariam parte do banco de dados para uso dos técnicos no Rio de Janeiro. As fotografias de Hess apresentam construções civis da cidade, de antigos 
estaleiros, do Colégio e da igreja de São Benedito (Figura 8, Figura 9 e Figura 10). O edifício dos Jesuítas foi contemplado com o maior número de fotografias externas e internas, observa-se nestas imagens grandes trechos de alvenaria da fachada exposta, presença de umidade nas argamassas, no claustro algumas pedras da alvenaria estão soltas, internamente o edifício ainda mantinha as antigas celas e no térreo ao nível da rua da Praia funcionava uma oficina mecânica e habitação para soldados (Figura 11, Figura 12 e Figura 13).

O interesse pela restauração do antigo Colégio dos Jesuítas ocorreu a partir da década de 1940 quando se deu início aos preparativos para o Tricentenário de fundação de Paranaguá, celebrado em 1948. Jornais paranaenses apontavam em fevereiro de $1946^{19}$ a vinda de Luís Saia em companhia de José Loureiro Fernandes à Paranaguá para avaliar o estado do antigo Colégio e a possibilidade de sua restauração. A partir daí percebemos que David Carneiro não participou de mais nenhuma atividade ligada ao IPHAN e Rodrigo Melo Franco já estabelecia contato com o professor José Loureiro Fernandes. Isso se explica pela mudança na organização administrativa do IPHAN, a partir do decreto no8534 que encerrou as atividades na $7^{a}$ Região, com sede em Porto Alegre, e criou a $4^{a}$ Diretoria com sede em São Paulo chefiada por Saia. Os primeiros contatos estabelecidos entre Rodrigo e Loureiro ocorreram em $1940^{20}$, período em que o professor estava na direção do Museu Paranaense, sediado em Curitiba. Em 1946 as cartas trocadas entre as personalidades intensificaram-se porque já eram iniciadas as discussões sobre a criação de um museu em Paranaguá.

\footnotetext{
${ }^{19}$ Correio da Manhã. Restauração de um monumento histórico. Correio da Manhã, 27 de fevereiro de 1946.

${ }^{20}$ Em um telegrama de 20 de abril de 1940, Loureiro reporta a Rodrigo sobre a ameaça de demolição de um sobrado do século XVIII que fora moradia dos Capitães-Mores de Paranaguá. Arquivo Central
} 

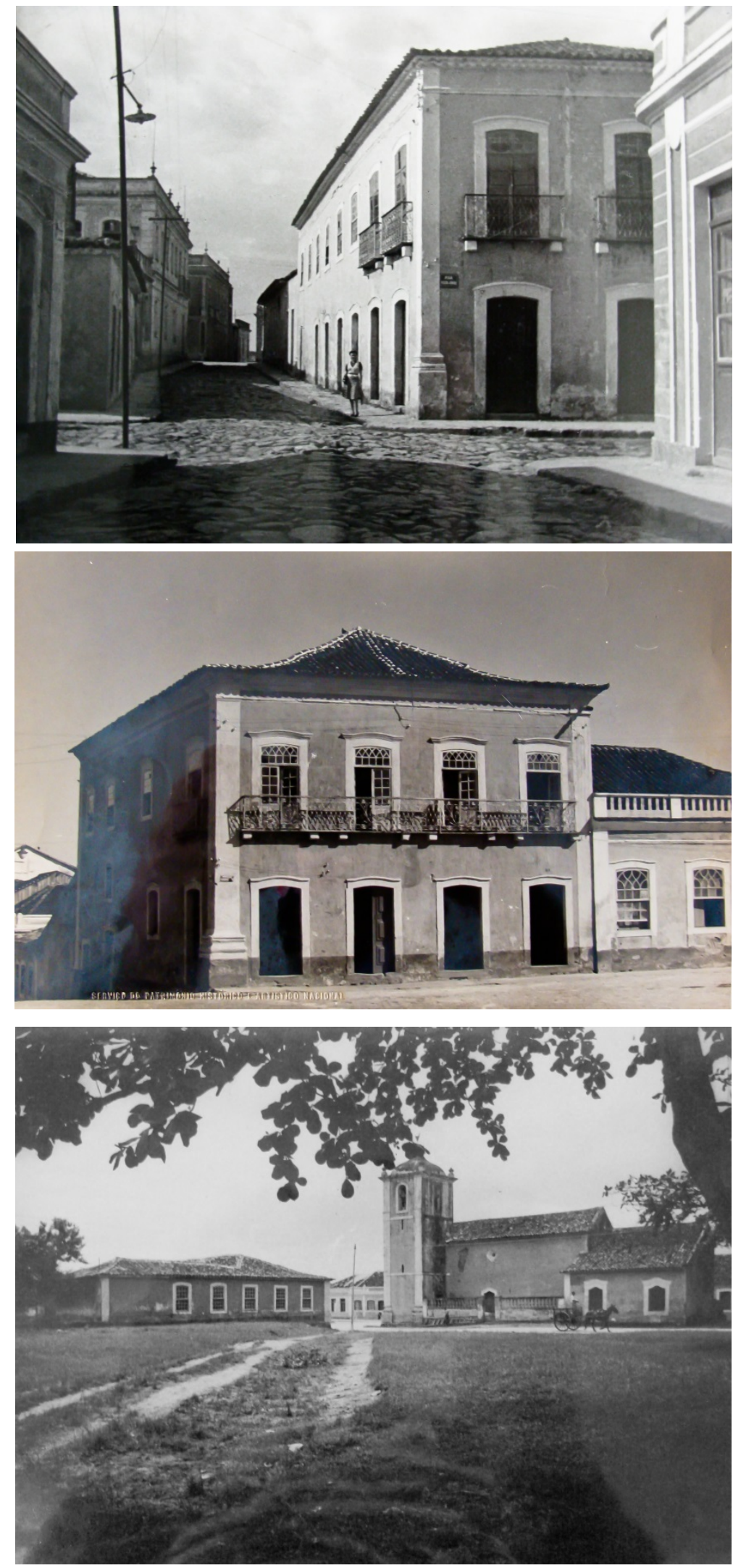

Figura 8: Casas na rua Fernando Simas, reparar que ainda se mantinha o calçamento antigo.

Fonte: HESS, Erich, 1940, Arquivo

Central do Iphan

Figura 9: Sobrado localizado no largo da Matriz.

Fonte: HESS, Erich, 1940, Arquivo Central do Iphan

Figura 10: Vista lateral da igreja de São Benedito.

Fonte: HESS, Erich, 1940, Arquivo

Central do Iphan 
Figura 11: Vista do Colégio dos Jesuítas a partir da rua da Praia, antes da primeira restauração.

Fonte: HESS, Erich, 1940, Arquivo

Central do Iphan

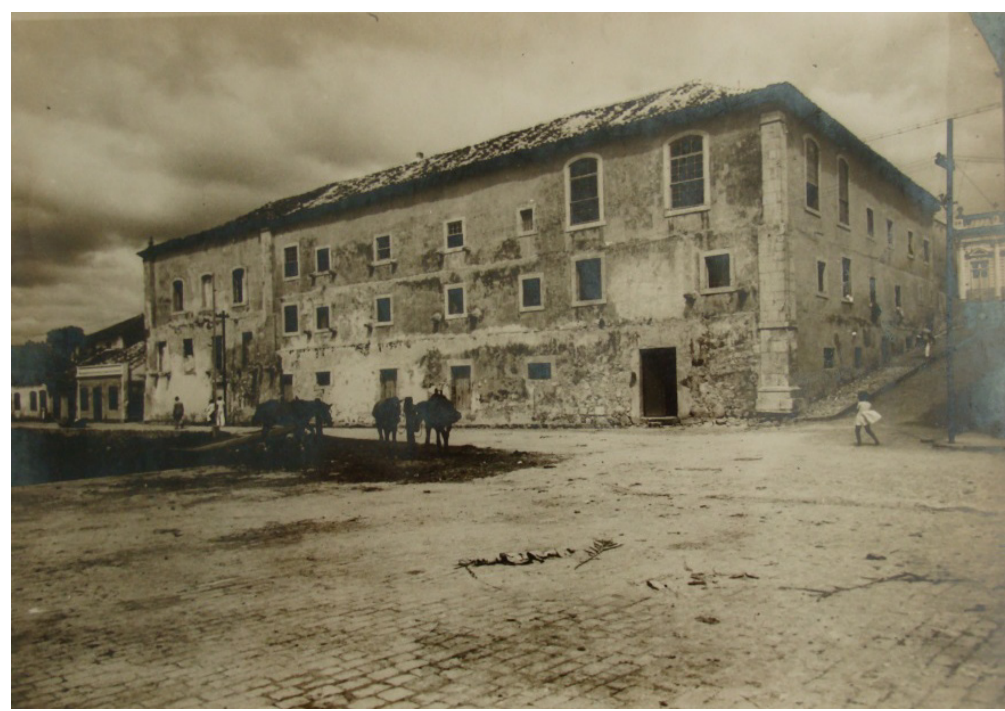

Figura 12: Imagem de uma das paredes da fachada da Rua da Praia, percebe-se o desgaste dos revestimentos.

Fonte: HESS, Erich, 1940, Arquivo Central do Iphan
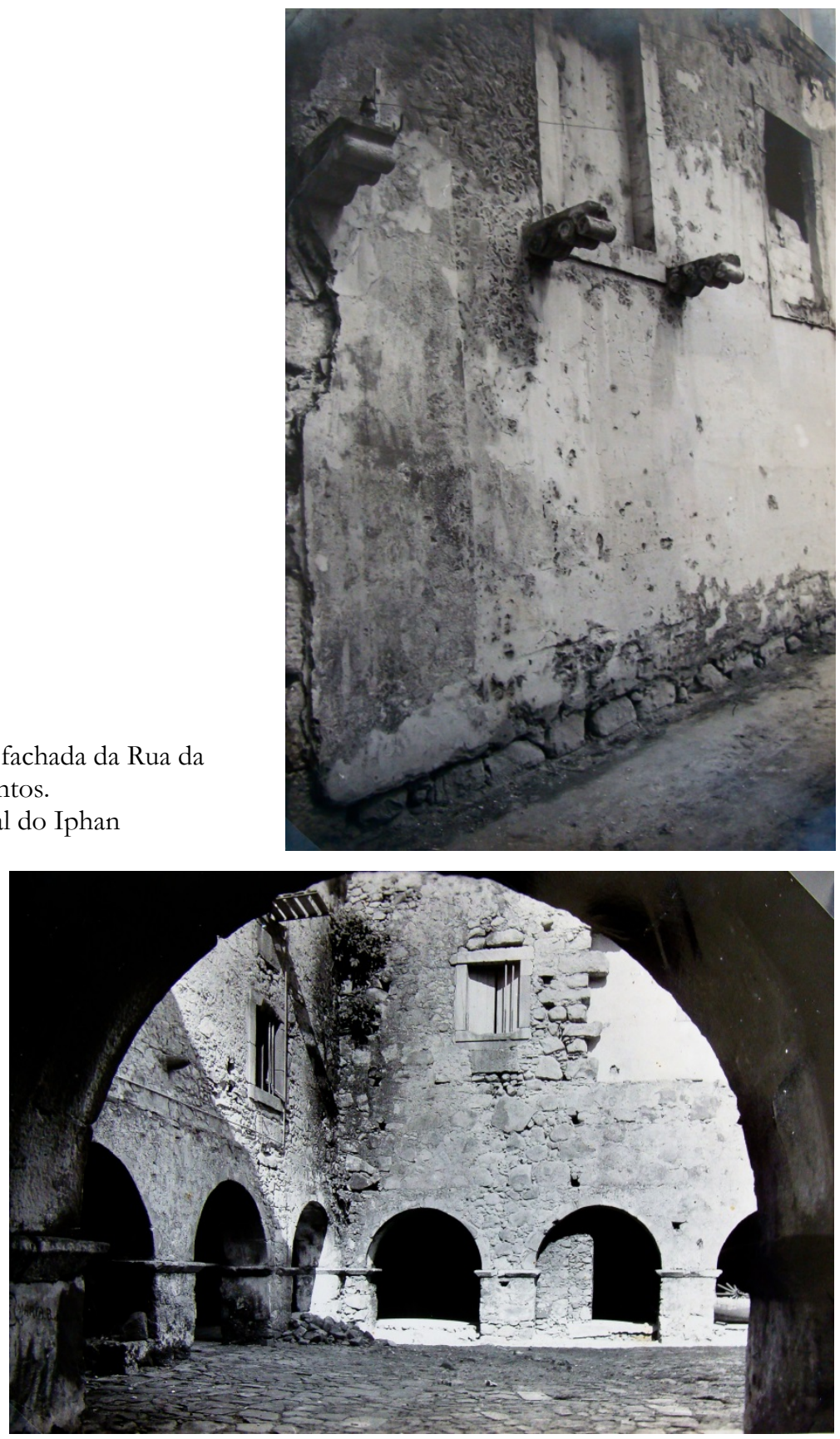

Figura 13: O claustro do Colégio dos Jesuítas

Fonte: HESS, Erich, 1940, Arquivo Central do Iphan 
José Loureiro Fernandes nasceu em Lisboa em 1903, formou-se em medicina pela Faculdade Nacional do Rio de Janeiro em 1927, foi professor de antropologia na Faculdade de Filosofia Ciências e Letras da Universidade do Paraná, entre 1938 a 1967, e diretor do Museu Paranaense, quando reorganizou a estrutura expositiva da instituição. Nesse período Loureiro estabeleceu contatos com o Museu Nacional do Rio de Janeiro e o Museu Paulista em São Paulo, fundou em 1929 o Círculo de Estudos Bandeirantes, que constituiu um acervo bibliográfico de temas relativos à filosofia, cultura, literatura e religião. Dedicou-se a pesquisa de arqueologia e etnografia, dentre as quais vale destacar os Sambaquis, os índios Xetás e os Caingangues. E foi um dos responsáveis pela formação do Museu de Arqueologia e Etnografia de Paranaguá, sediado no antigo Colégio dos Jesuítas.

Em 1948, Luís Saia foi solicitado novamente por Loureiro ${ }^{21}$ para iniciar o projeto de restauro e adaptação do Colégio Jesuíta como parte das comemorações do Tricentenário de Paranaguá que ocorreria em 29 de julho de 1948. Luís Saia se preparou para a viagem fazendo um levantamento no Arquivo do Estado de São Paulo dos documentos relativos ao Paraná e sugeriu avaliar outros possíveis monumentos durante a viagem, também propõe a Rodrigo a ida do paranaense Vilanova Artigas para auxiliá-lo. ${ }^{22}$ Por fim, Saia realizou o levantamento no início de julho de 1948, os únicos documentos encontrados são fotografias de construções da cidade (Figura 14 e Figura 15), nenhum inventário, desenhos ou textos foram localizados nos três arquivos do IPHAN. Do levantamento fotográfico, o maior destaque foi dado para a Fonte Velha, uma fonte de água construída no século XVII, localizada nas proximidades da igreja de São Benedito e que não constava nos levantamentos anteriores de David Carneiro e nas fotos de Eric Hess.

Luís Saia retornou para os festejos do Tricentenário em 29 de julho do mesmo ano representando Rodrigo Melo Franco de Andrade. O diretor do IPHAN foi convidado por Loureiro para as festividades, mas na impossibilidade de

\footnotetext{
${ }^{21}$ Nesse período Loureiro era Secretário de Estado da Educação e Cultura do Paraná.

${ }^{22}$ Carta de Luís Saia à Rodrigo Melo Franco de 16 de junho de 1948. (Arquivo Central).
} 
comparecer solicitou à Saia que o representasse, o secretário enfatizou a importância da vinda do representante do SPHAN em telegrama de 21 de julho de $1948^{23}$ :

O Tricentenário foi um fato importante nas atividades de preservação do patrimônio e do reconhecimento do IPHAN como órgão de preservação pelo Governo do Estado e pela Prefeitura de Paranaguá. O evento propagou de certa maneira a importância histórica da cidade e de suas construções; apesar desta história estar ligada a nomes importantes de uma "tradição parnanguara" e de sua classificação como "berço da civilização paranaense" termo muito propagado pelos representantes locais, pela imprensa e por objetos comemorativos. A iniciativa teve como responsável o prefeito João Eugenio Cominese que solicitou a colaboração do Governo do Estado para a organização dos festejos e a criação de uma comissão formada por tradicionais famílias da cidade, membros do Instituto Histórico, representantes do porto e do eclesiástico local. José Loureiro foi incumbido de representar o governo e se envolveu ativamente na organização. Em maio de 1948 convocou uma reunião para discutir a preparação dos festejos e sugeriu que fossem realizados em conjunto o $1^{\circ}$ Congresso de Geografia e História ${ }^{24}$.

Pela proposta apresentada nos jornais daquele período, as festividades deveriam ter grande repercussão não só por sua importância histórica para o Paraná, mas também em relação à ocupação do Sul do Brasil. Uma das principais propostas estava relacionada ao Colégio:

O dr. Loureiro Fernandes, referindo-se ao assunto, esclareceu que o Convento dos jesuítas já se acha tombado como monumento nacional no Serviço do Patrimônio Histórico e Artístico Nacional e que fará encaminhar o apelo da Comissão Central, no sentido de poder ser desocupado até julho o edifício onde funcionam serviços administrativos afim de que seja instalada nele a Exposição Comemorativa e, posteriormente o Museu de Paranaguá. ${ }^{25}$

\footnotetext{
${ }^{23}$ Telegrama de José Loureiro à Rodrigo Melo Franco de Andrade de 21 de julho de 1948. (Arquivo Central)

${ }^{24}$ Carta de João Eugênio Cominese de 15 de maio de 1948. (Acervo do IHGP).

25 Jornal Gazeta do Povo de 30 de junho de 1948.
} 


\section{PARANAGUÁ: IDENTIDADE E PRESERVAÇÃO}

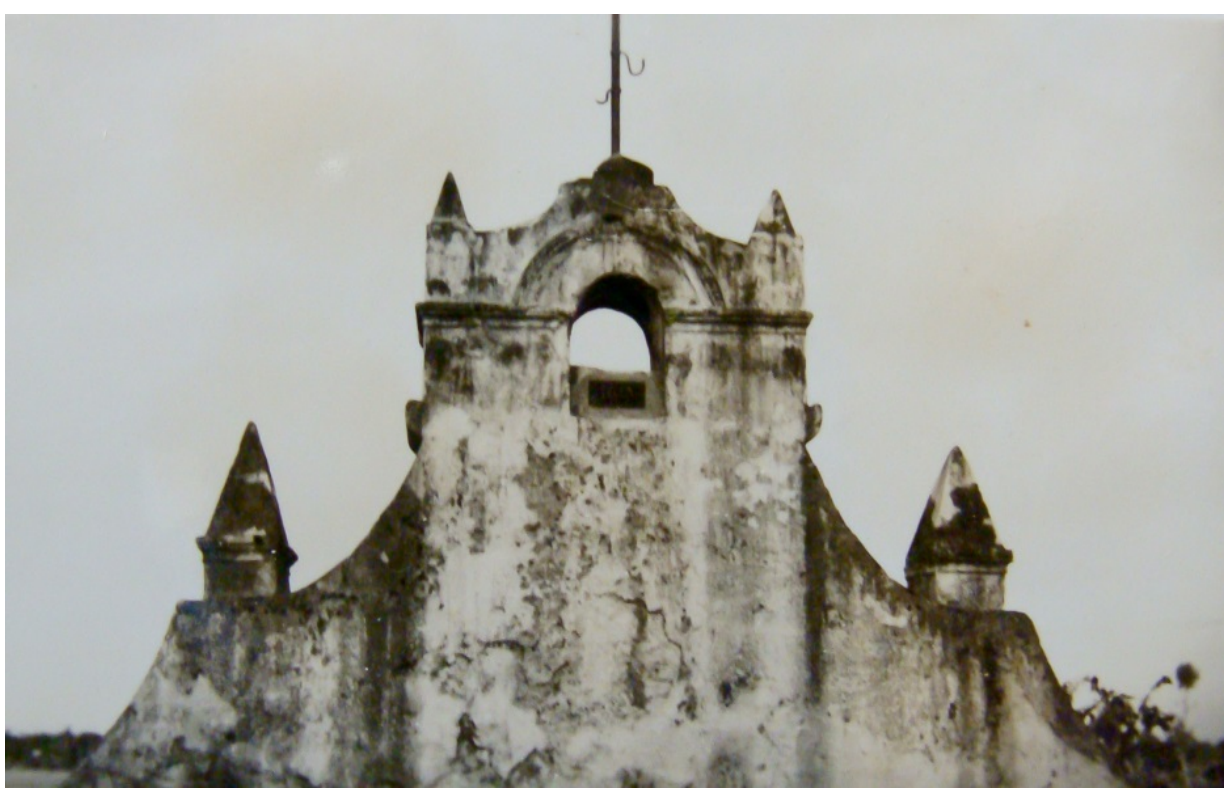

Figura 14: Casa na Rua Marechal Deodoro. Fonte: SAIA, Luís, 1948, Arquivo Central do Iphan

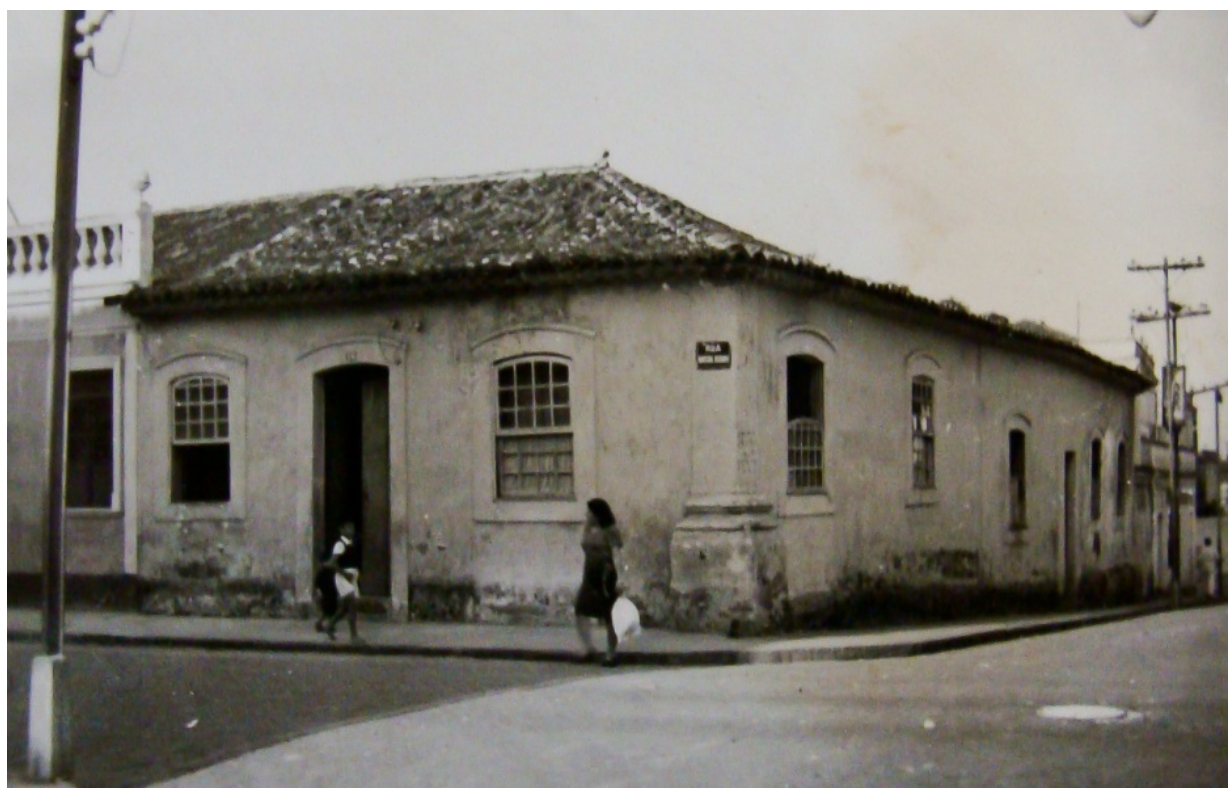

Figura 15: Detalhe da

Fonte Velha.

Fonte: SAIA, Luís, 1948, Arquivo Central do Iphan

As festividades aconteceram entre os dias 23 a 29 de julho, mas a exposição não foi realizada no antigo Colégio como fora desejada, a alternativa foi abrigá-la na Escola Normal Dr. Caetano Munhoz Da Rocha, edifício eclético de grandes proporções construído na década de 1920. Na exposição estiveram presentes representantes de órgãos do município e dos Estados, dentre os quais Luís Saia do IPHAN de São Paulo (Figura 16) e David Carneiro do Museu Coronel David Carneiro, as presenças são confirmadas pelas assinaturas no livro de visitas da exposição ${ }^{26}$. A "Exposição Retrospectiva de Paranaguá" apresentava nas 12 salas objetos dos mais variados tipos, dos séculos XVII ao XX, como mobiliário, louças,

${ }^{26} \mathrm{O}$ livro de assinaturas se encontra no arquivo do Instituto Histórico e Geográfico de Paranaguá. 
livros, selos, jornais, pinturas, fotografias e etc. que foram cedidos pela prefeitura, igrejas e famílias tradicionais da cidade. Estavam expostos em uma das salas serviços para café, prataria, oratórios, vasos de porcelana, escarradeiras, em outra sala pinturas à óleo de Alfredo Andersen (1860-1935), havia a sala de arte religiosa pertencentes as Igrejas Matriz e São Benedito, a sala de fotografias, uma de mobiliário, outra de vestuário, uma de livros, outra de jornais e revistas e uma sala de artesanato litorâneo que expunha principalmente objetos em palha como chapéus, cestaria, em barro e de madeira, o corredor abrigava uma coleção de caixas de fósforo de diversas partes do mundo. ${ }^{27}$

Figura 16: A fotografia apresenta um dos discursos de Loureiro Fernandes (ao centro da imagem) na Câmara Municipal de

Paranaguá durante os festejos do tricentenário em que está presente Luís Saia (no canto esquerdo em pé de paletó claro).

Fonte: Acervo do Instituto Histórico e Geográfico de

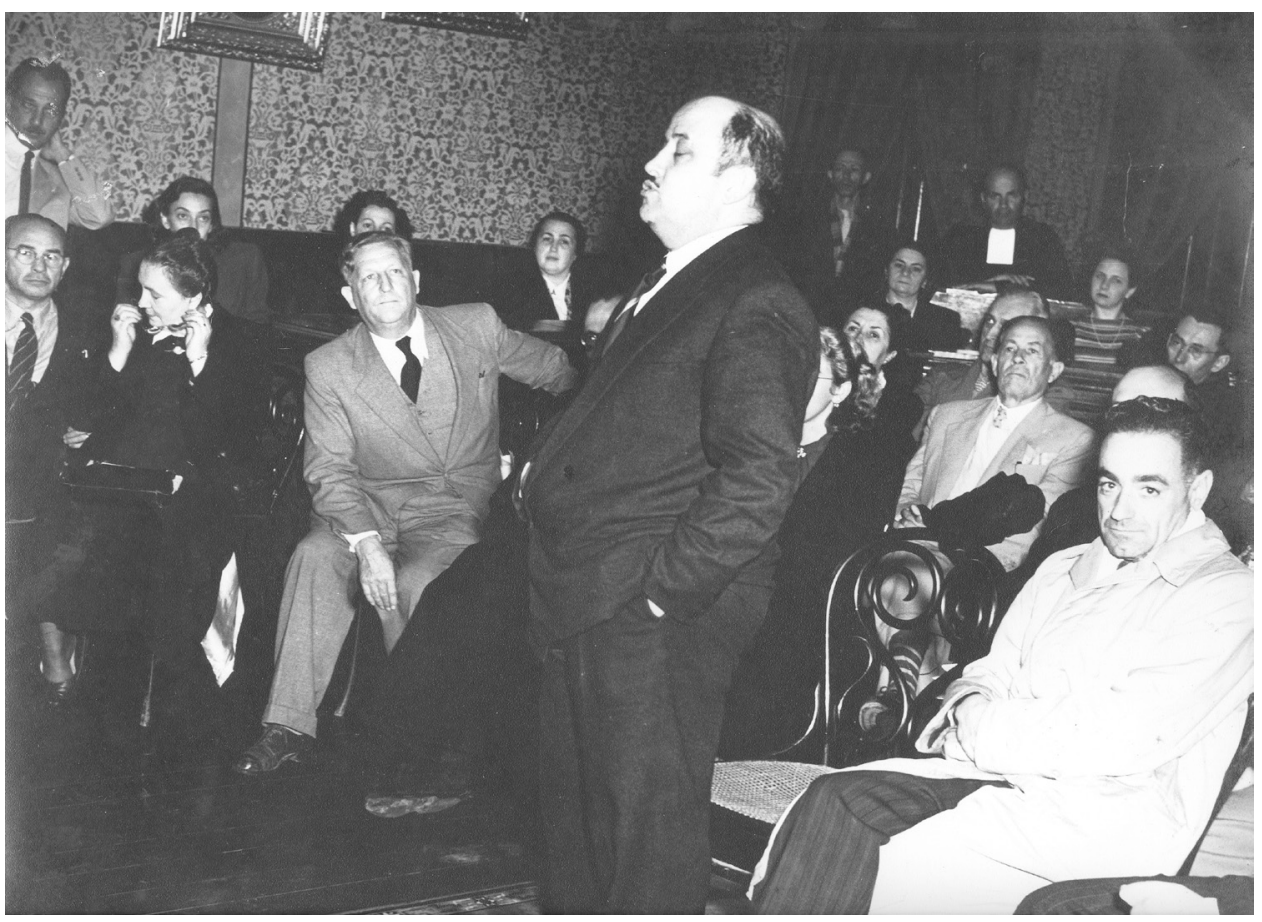
Paranaguá

A exposição foi a primeira experiência para a criação de um museu municipal em Paranaguá, mas serão décadas para consolidar a ideia após as restaurações e o envolvimento do IPHAN nessas atividades. Apesar da presença de Luís Saia, não encontramos nas publicações oficiais do Tricentenário nenhuma menção sua. Presumimos que o convite de Loureiro teve como objetivo principal estreitar as

\footnotetext{
27 As informações sobre a exposição estão contidas no manuscrito de Annibal Ribeiro Filho, membro do IHGP, de 1974 e pertencente ao acervo do Instituto.
} 
relações dos governos estadual e municipal com o IPHAN em prol da restauração do antigo Colégio dos Jesuítas.

A comunicação entre Rodrigo Melo Franco e José Loureiro ${ }^{28}$ foi intensificada durante as obras no Colégio, as cartas são importantes fontes que nos apresentam os procedimentos e evidenciam a centralização das decisões na Central carioca. Oficialmente, a criação do Museu de Paranaguá no antigo Colégio se deu em 3 de junho de $1949^{29}$ a partir de decreto do governador Moyses Lupion (19081991). Foi o ponto de partida para a primeira obra de restauração que perdurará por muitos anos. Nesta fase percebe-se a insistência de Loureiro no andamento das obras e os sérios problemas ocasionados pelo visível desinteresse da $4^{a}$ D.R. que resultou em desentendimentos entre José Loureiro e Rodrigo Melo Franco.

A falta de importância dada à Paranaguá nas políticas de preservação e mais especificamente ao Museu no Colégio dos Jesuítas pelo IPHAN é perceptível em algumas cartas de José Loureiro. Apesar das insistentes cobranças do professor à Central carioca, uma das mais contundentes cartas, de abril de 1960, merece a análise de alguns trechos, primeiro Loureiro constatava problemas em obras na antiga cadeia na cidade da Lapa e a falta de respostas do IPHAN:

Por outro lado não quero me envolver nesse caso da Lapa pois é frequente dizer-se que $\mathrm{o}$ Patrimônio não se interessa com os "tombamentos do Paraná", e no caso da cadeia da Lapa o David Carneiro é que não se devia descuidar, pequenas reformas foram sendo progressivamente feitas e ninguém se manifestou, é estranho que os próprios elementos do Patrimônio que aqui passaram não se houvesses interessado pelos "tombamentos" $[\ldots]^{30}$

Percebe-se que no Paraná já era de conhecimento geral o descaso da Instituição federal e de seus técnicos ao patrimônio paranaense. Loureiro afirmou,

\footnotetext{
28 No livro "José Loureiro Fernandes: O Paranaense dos Museus", Maria Regina Furtado analisa a atuação de Loureiro na criação do Museu de Arqueologia de Paranaguá e na readequação do Museu Paranaense. Segundo a autora (2006), o contato de José Loureiro com Rodrigo Melo Franco se deu a partir do intermédio de David Carneiro, quando então o diretor do IPHAN solicitou a Loureiro, em 1937, informações sobre o Museu Paranaense, para inseri-lo no cadastro elaborado pelo Serviço do Patrimônio.

29 Telegrama do Secretário de Cultura Fernando Correia Azevedo a Rodrigo Melo Franco, em 4 de junho de 1949 (Arquivo Central)

${ }^{30}$ Carta de José Loureiro Fernandes a Rodrigo Melo Franco de Andrade em 12 de abril de 1960. (Arquivo Central)
} 
na mesma carta, estar sobrecarregado e reclamou a falta de assistência técnica, chegando ao limite de comunicar sua possível saída da administração do museu:

Peço releve-me a franqueza, não desejava escrever-lhe esta carta mas diante do que aconteceu com a construção ao lado do Colégio, fato que pessoalmente me causa muitos aborrecimentos, sem qualquer resultado ao interesse da comunidade, começo a pensar que melhor seria o Reitor, em combinação com o DPHAN encarregar um outro professor do caso do Museu de Paranaguá.

A ausência dos técnicos não pode ser apenas justificada pela falta de profissionais na instituição, mas também pela excessiva centralização que marcou a fase heroica do IPHAN. Todas as decisões passavam pela anuência de Rodrigo Melo Franco, e em sua ausência havia quase total paralização dos trabalhos, neste trecho da carta de Alfredo Rusins em resposta a José Loureiro isto fica evidente:

Durante dias ele não veio à repartição, e logo a seguir sua irmã Vera, que reside com sua mãe e cuidava dela, caiu em casa e fraturou a cabeça do fêmur. As aflições do nosso estimado chefe aumentaram de muito. E os assuntos da repartição, aguardando suas soluções, também. As coisas de Paranaguá, de que fui porta-voz, dormiram no meu relatório, com restrições e negativas em alguns pontos por parte dos arquitetosassistentes, na mesa do Dr. Soeiro, aguardando pelo Dr. Rodrigo. ${ }^{31}$

Nessa perspectiva, não é possível analisar e compreender as atividades da instituição do patrimônio sem associá-la ao seu primeiro diretor, pois: "A criação e sedimentação do SPHAN é indissociável da imagem pública de Rodrigo." (GONÇALVES, 1996, p.47). Fica claro que qualquer ausência do diretor, atrasava as decisões sobre obras e outros assuntos que percorriam não apenas o Paraná, mas outros Estados brasileiros.

Outro ponto de reflexão refere-se à postura dos técnicos da Direção paulista, o relatório da vistoria realizada por Saia, em 3 de julho de 1948, nos apresenta as diretrizes tomadas em relação ao restauro do Colégio Jesuíta. Em seu relatório Saia apontou que o edifício servia de morada para três famílias de pessoas do exército,

${ }^{31}$ Carta do engenheiro Alfredo Rusins a José Loureiro Fernandes em 18 de junho de 1959. (Arquivo Central) 
vivendo em condições precárias. De maneira geral as indicações do arquiteto direcionam para a mínima intervenção:

Tirante as paredes demolidas (da igreja) e um muro recente e um patamar de entrada, modificações essas que devem datar do fim do século passado (o segundo volume do Vieira dos Santos deve esclarecer este problema (a premência de tempo e a relativa desimportância da questão protelaram a verificação para um tempo mais oportuno), o restante da estrutura e das paredes está em relativo bom estado apenas carecendo de reparos ligeiros, mesmo porque nos parece inteiramente desaconselhável, no caso de obras, que se proceda a uma revisão geral do revestimento. Tal iniciativa viria encarecer por demais os trabalhos e crearia problemas de composição plástica de certos ângulos difíceis de serem resolvidos. Por exemplo: o lado da demolida igreja. Nos parece que o mais razoável seria trabalhar a construção no sentido apenas de alimpa-la de coisas erradas e protege-la nas partes desgastadas. ${ }^{32}$.

Também aconselhava a limpeza dos pisos de pedra e o reaproveitamento de pelo menos metade dos assoalhos de madeira, assim como os forros. Há um aspecto que vale a atenção, refere-se à forma de tratamento das alvenarias:

De acordo com o ponto de vista já enunciado, achamos conveniente executar os trabalhos externos de modo a não se tornar necessária nenhuma pintura. $\mathrm{O}$ mesmo não se pode pensar para a parte interna que deverá ser toda pintada; nas paredes por razões óbvias e nas partes de madeira como medida de proteção ${ }^{26}$.

Não foi exposto o motivo da proposta de manter daquela maneira as fachadas externas do edifício, as fotografias de Hess mostram que as alvenarias estavam com as marcas do tempo, o que Cesare Brandi (1906-1988) ${ }^{33}$ define como "pátina do tempo". Portanto, analisando esta proposta a partir das obras de referência na carreira de Saia deste mesmo período, surge um questionamento que se refere à solução adotada para o plano de restauração: Por que Saia propõe a mínima intervenção no Colégio Jesuíta e no projeto do Sítio Santo Antônio, em São Roque, há necessidade de ocultar todas as imperfeições e estabelecer a imagem da casa bandeirista completamente caiada?

\footnotetext{
32 Relatório da vistoria feita por Luiz Saia no Colégio dos Jesuítas de 20 de julho de 1948. (Arquivo Central)

33 "Vimos que, historicamente, a pátina documenta a própria passagem da ora de arte no tempo e portanto deve ser conservada.” (BRANDI, 2005, p. 85).
} 
São posturas completamente distintas num mesmo período. Uma que faz lembrar em parte as premissas de John Ruskin (1819-1900), da mínima intervenção, segundo Carbonara (2010), Ruskin defendia o mínimo possível para a manutenção que permitiria prolongar a vida do edifício, apesar de que seria inevitável sua destruição. Para ele a arquitetura era memória, testemunho do passado e da vida de gerações passadas, mas ainda não era apontada como documento (CARUNCHIO, 1996). Outra na vertente de Viollet-le-Duc ${ }^{34}$, da pureza de estilo, em se colocar no lugar do arquiteto \construtor do antigo edifício. Porém, nos casos paulistas, existe a busca de retorno ao "original", a partir do uso do concreto ciclópico, da regularização das alvenarias e das paredes caiadas de branco que caracterizavam o restauro empreendido no Sítio Santo Antônio (1940), em São Roque e que se tornou procedimento comum a outras obras em São Paulo. Numa análise geral, Mayumi (2008, p.292-293) comenta as restaurações empreendidas por Saia:

Curiosamente, as operações de limpeza também podem ser consideradas operações de saneamento, porém de ordem estética, na medida em que se propunham a purificar o monumento original de seus acréscimos arquitetônicos e modificações consideradas espúrias. $\mathrm{O}$ rejuvenescimento de todos os exemplares restaurados faz parte do paradigma como decorrência natural da substituição dos revestimentos preexistentes pelos novos, aos quais se aplicou invariavelmente a pintura alva à base de cal, fazendo sobressair as janelas e portas restauradas e escurecidas com extrato de nogueira.

Pelo relatório do Colégio Jesuíta, Saia não pretendia interferir de modo drástico no antigo edifício. Sua proposta focava apenas na limpeza das argamassas e das paredes de pedra, motivadas por razões econômicas, evitando até a pintura das fachadas externas. A economia nas obras também foi uma das condicionantes nas atividades de restauro.

O refazimento das argamassas traria um problema, na opinião do arquiteto, nos encontros das paredes de argamassa com a alvenaria exposta, problema de "composição plástica". Percebemos a preocupação na manutenção das alvenarias expostas, sem a necessidade de recobri-las, essa preocupação influenciará nas

34 VIOLLET-LE-DUC, Eugène Emmanuel. Restauração. Tradução por KÜHL, Beatriz Mugayar. $4^{a}$ Ed. São Paulo: Cotia, 2013. 
próximas propostas para o restauro do Colégio e nas alterações do acesso principal. O primeiro parecer simplificado gerou posteriormente atitudes mais complexas para a intervenção.

A postura de Saia, na primeira proposta, permite outra reflexão, que se dá a partir das técnicas construtivas, a taipa de pilão e a pedra e cal, são duas técnicas distintas que possibilitam maneiras distintas de restauração. Porém, em outro exemplo de pedra e cal, o Forte São João da Bertioga, em Bertioga, projeto de restauro de Saia (1942), teve o tratamento de suas superfícies à mesma maneira que no Sítio Santo Antônio, segundo Claudia Reis Cunha (2010, p. 146), “[...] foram cuidadosamente repintadas, apagando completamente as marcas da passagem do tempo representada pela pátina.”

Mas a proposta não foi mantida para as obras no Colégio dos Jesuítas que se desenrolaram por mais de uma década. A falta de corpo técnico, as constantes mudanças na responsabilidade da obra e os conflitos entre as instâncias, marcaram a primeira restauração empreendida em Paranaguá. Alguns aspectos destas obras nos permite refletir sobre os procedimentos metodológicos e de que maneira se fundamentavam, são situações que demonstram a falta de documentação e de levantamentos detalhados sobre as soluções empreendidas.

A partir da criação do museu em 1949, Luís Saia foi novamente solicitado por Rodrigo para iniciar o projeto e organizar as obras de restauração. $\mathrm{O}$ arquiteto sugeriu que fossem realizados não só os levantamentos necessários para o Colégio, mas também de outras obras de interesse. Houve a análise pela Central carioca, mas os documentos que tratam das decisões sobre o assunto não foram encontrados; possivelmente a atividade não foi realizada porque, um ano depois, Rodrigo Melo Franco convidou o engenheiro-arquiteto Carlos Eugênio Contin, residente em Curitiba, para acompanhar a primeira restauração. Esta experiência inicial foi marcada por muitos problemas na execução e no acompanhamento das obras, tanto que durante a execução foi descoberto que Contin não possuía titulação. A informação se confirma através da solicitação do seu registro no CREA pelo 
Tribunal de Contas da União. Pela justificativa de Contin, podemos supor os motivos que levaram a seu convite: sua indicação pode ter vindo de Lucio Costa ou de seu irmão Audomaro Costa que já havia trabalhado com Contin no Departamento Administrativo do Serviço Público. ${ }^{35}$

Mas retornando a atuação de Saia, devemos aprofundar sobre seu papel nas obras do Colégio a partir da proposta para reformulação do acesso ao museu, mas antes se faz necessário descrever algumas características deste monumento. $\mathrm{O}$ Colégio dos Jesuítas é um edifício retangular de grandes dimensões, construído na primeira metade do século XVIII, o terreno, em desnível, possibilitou a construção de três pavimentos na rua General Carneiro e um pavimento na rua XV de Novembro (Figura 17), via em que estava situada a antiga igreja, demolida no final do século XIX. Tem por características principais as alvenarias em pedra, argila e cal de conchas, o claustro e os marcos de portas e janelas em granito (Figura 18 e Figura 19).

Durante o ajardinamento, em 1959, das áreas situadas na rua XV de Novembro foram descobertas ruínas que motivaram a interrupção das obras. Com a descoberta, surgiu novamente a hipótese sobre a lenda dos subterrâneos construídos pelos padres jesuítas para permitir a fuga em qualquer ameaça existente, agora defendida por José Loureiro. Foi notado que a parede que limitava o claustro descia pelo menos dois pavimentos em relação ao nível da rua XV de novembro (Figura 20). Houve também a proposta de retirar o fechamento em pedra dos arcos existentes nessa parede dando visão da rua para o claustro. Um dos trechos da carta de Loureiro sobre as descobertas no Colégio nos esclarece sobre qual tipo de material documental foi suporte no direcionamento dos técnicos para

\footnotetext{
35 "Em meu favor, todavia, devo esclarecer que no Serviço de Obras exercí efetivamente as funções de engenheiro, e que algumas das muitas obras realizadas por aquela repartição, foram executadas através de projetos de minha exclusiva autoria.

Iniciei-me no Serviço de Obras nas funções de Auxiliar Técnico e, mais tarde, por deliberação única do DASP, passei, e também o meu colega Audomaro Costa, irmão do distinto arquiteto do Patrimônio, Dr. Lucio Costa a figurar no quadro de extra-numerarios, com a designação de Engenheiro XVII, para logo a seguir ser promovido a Engenheiro XIX." (Carta de Carlos Contin a Rodrigo Melo Franco em 16 de julho de 1952 - Arquivo Central)
} 
as ações de restauro, grande parte se deve aos levantamentos de 1850 de Antonio Vieira dos Santos ${ }^{36}$ :

Quando o Dr. Barreto esteve conosco em Paranaguá, perguntei-lhe se não havia conveniência de retirar o aterro que, do lado da Rua Quinze, havia sido feito contra a parede posterior do $2^{\circ}$ piso do convento, pois, assim seria possível abrir-se os arcos que existem nessa parede, os quais primitivamente deveriam estar abertos. Conversamos muito sobre isso, mas como havia sido tomado como base para a restauração a planta que figura na obra de Vieira dos Santos, a qual foi levantada em 1850 quando a alfandega se encontrava instalada no edifício e já sofrera modificações nada se resolveu. A descoberta desta espécie de segmento de torre quadrangular soterrada, levantou novamente o problema do "famoso subterrâneo" que dizem existir do lado oposto. ${ }^{37}$

Paulo Thedim Barreto autorizou a escavação da área com o intuito de analisar os registros arqueológicos, a hipótese do arquiteto era de que seria a base da torre da igreja, contrariando a suposição apontada por Loureiro. Quanto ao uso do livro de Vieira dos Santos, outras propostas terão como base o levantamento de 1850, como aquelas elaboradas por Saia.

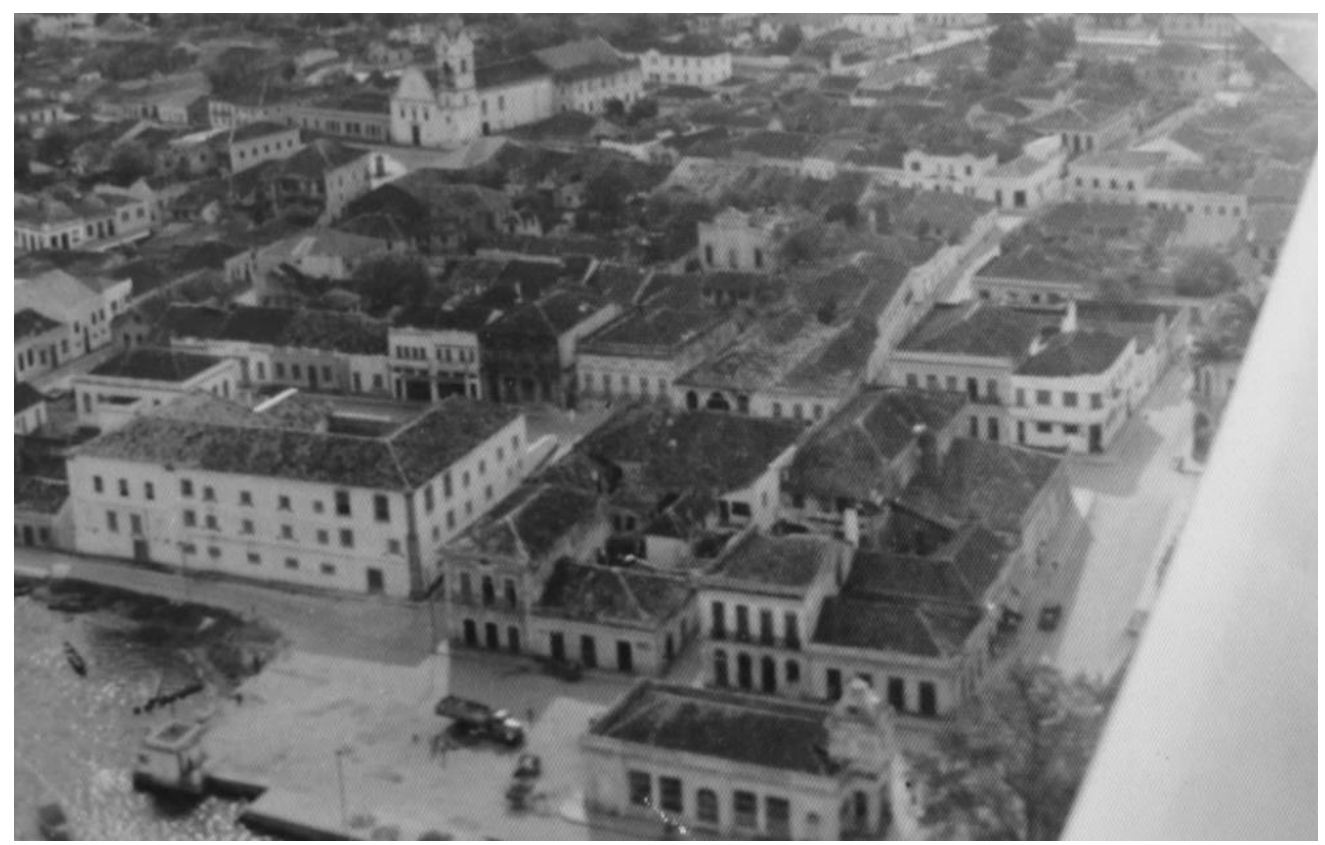

Figura 17: panorama geral do edifício do Colégio Jesuíta, o rio Itiberê ainda estava próximo ao monumento. $\mathrm{Na}$ extremidade esquerda do edifício está a sede do IHGP. Fonte: Arquivo Central do Iphan, fins dos anos 1950

\footnotetext{
36 Antonio Vieira dos Santos produziu em 1850 um registro de obras de arquitetura em Paranaguá, dentre os quais do Colégio Jesuíta contendo plantas e elevações e foi uma importante referência para as primeiras propostas de restauração.

${ }^{37}$ Carta de José Loureiro Fernandes a Rodrigo Melo Franco em 26 de maio de 1959.
} 


\section{PARANAGUÁ: IDENTIDADE E PRESERVAÇÃO}

Figura 18: Vista do claustro e seus muros expostos em pedra e cal. Fonte: Acervo do autor, 2013.

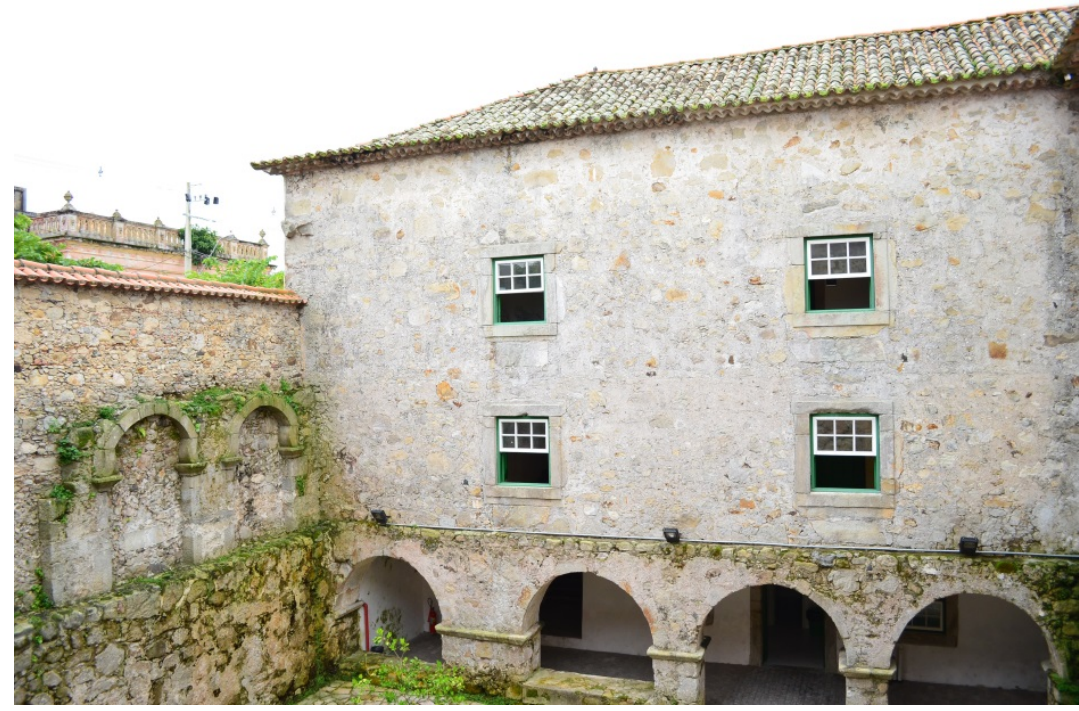

Figura 19: A visão do Colégio a partir do aterro.

Fonte: Acervo do autor, 2013.

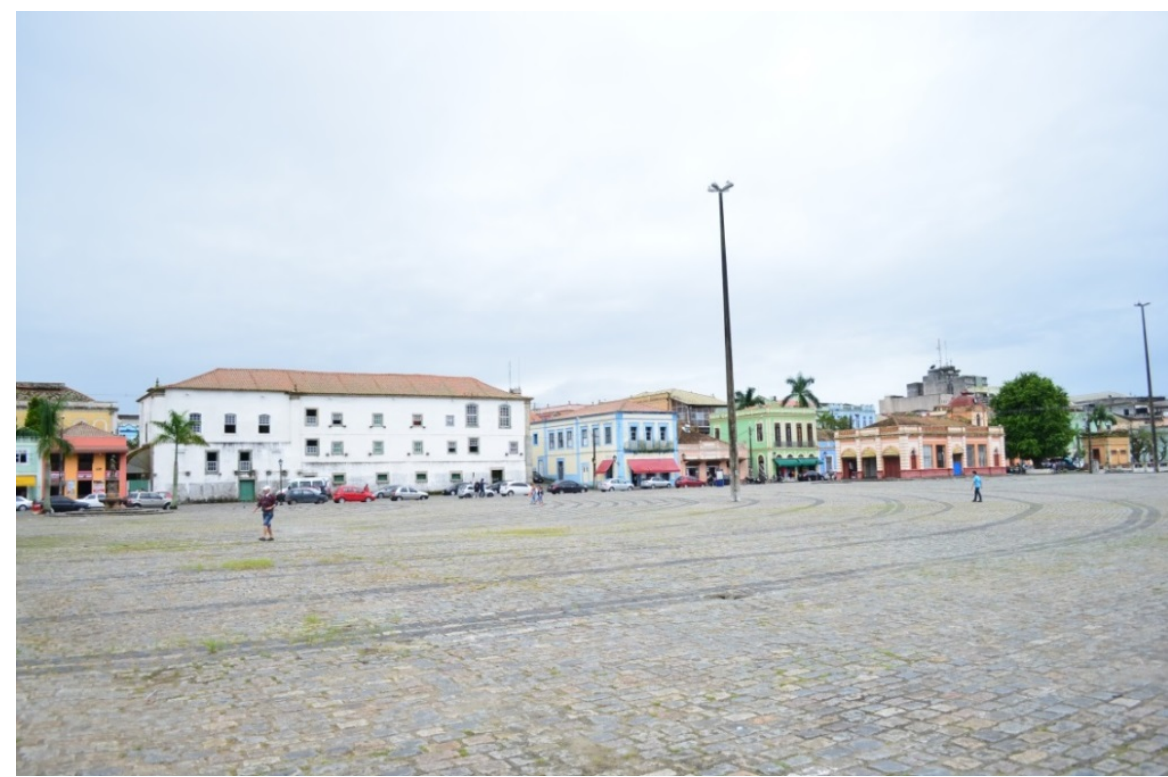

Figura 20:

Registro

fotográfico das

escavações arqueológicas com registros escritos de José Loureiro Fernandes. Fonte:

Arquivo Central do IPHAN,

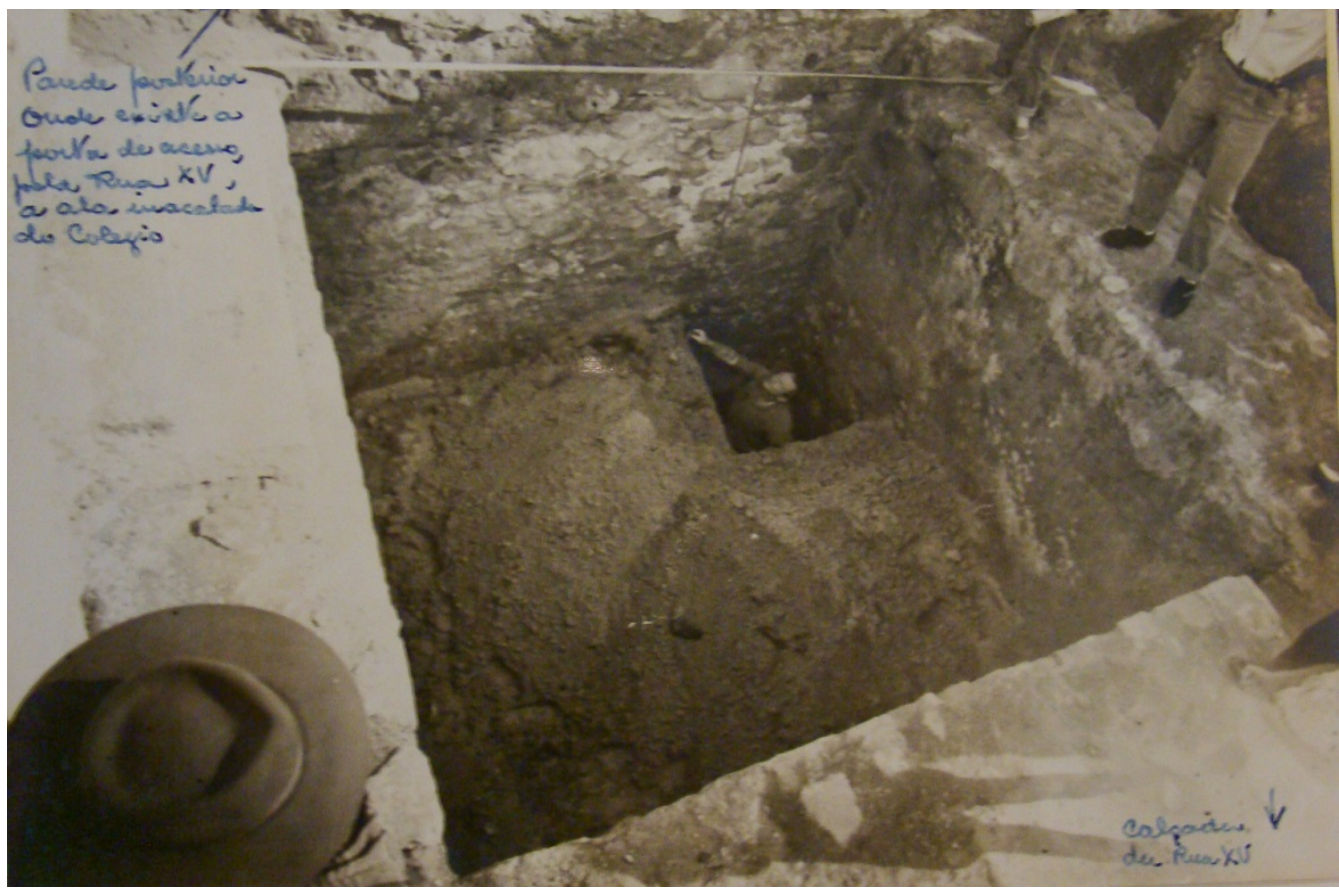

1959. 
Vale lembrar que as discussões sobre arqueologia e patrimônio estavam presentes na Conferência Geral da UNESCO ${ }^{38}$ em Nova Delhi, de 1956, e que destaca a importância das escavações arqueológicas para o conhecimento das diferentes civilizações e aponta a necessidade do controle e responsabilidade do Estado frente à atividade, tema que já estava timidamente citado na Carta de Atenas de 1931.

Em novembro de $1959^{39}$ foi solicitada a ajuda de Luís Saia e enviada ao arquiteto a proposta para o novo acesso elaborada por Renato Soeiro com o auxílio de Lucio Costa e José Souza Reis. A proposta dos técnicos da Central carioca tem como ponto principal a demolição do edifício anexo, localizado na rua XV de novembro e da parede lateral da antiga igreja, a proposta gráfica não foi encontrada nos arquivos pesquisados, apenas a descrição de Rodrigo Melo Franco. O desenvolvimento do projeto do novo acesso após o primeiro estudo ficou a encargo de Luís Saia que, apesar de não ter participado das primeiras obras de restauração do Colégio, esteve em contato com Loureiro, que lhe pediu para auxiliá-lo na montagem do Museu de Arqueologia. Entretanto nem dessa maneira houve a presença imediata de um técnico da Diretoria paulista para auxiliar nas obras.

Pela proposta de $\mathrm{Saia}^{40}$ o pequeno edifício, já restaurado anteriormente, seria demolido, mas ele sugeriu que a antiga parede fosse mantida como ruína, com a retirada do revestimento, mantendo a estrutura de pedra (Erro! Fonte de referência não encontrada.). Também seria retirado o fechamento de uma porta já existente nessa parede que faria parte do caminho para o acesso ao museu. Entre a antiga parede e o claustro, Saia propõe a construção de uma laje de concreto, como um terraço jardim, com a colocação de terra e a plantação de grama, e de um guarda-corpo de

\footnotetext{
38 Recomendação que define os princípios internacionais a serem aplicados em matéria de pesquisas arqueológicas Conferência Geral da UNESCO - 9 ${ }^{a}$ sessão - Nova Delhi - 5 de dezembro de 1956. In: CURY, Isabelle (Org)Cartas Patrimoniais. $3^{a}$ Edição. Edições do Patrimônio: Brasília, 2004.

${ }^{39}$ Carta de Rodrigo Melo Franco a Luís Saia em 13 de novembro de 1959.

${ }^{40}$ Carta de Luiz Saia a Rodrigo Melo Franco em 27 de abril de 1960.
} 
madeira que permitiria a visualização do claustro a partir da entrada. Seriam mantidos ainda alguns pilares de pedra. Para dar mais clareza ao acesso principal, a outra porta existente no lado esquerdo seria retirada para dar lugar a uma janela. E a escada de dois lanços seria demolida. A área da antiga igreja seria fechada por um muro baixo para delimitar o espaço do museu e do jardim. Isso foi motivado pelas ameaças de apropriação da área por organizações estudantis que estavam buscando uma sede devido à demora na instalação do museu.

Em junho de 1960 foi iniciada a demolição do anexo com a supervisão de Loureiro e com visitas esporádicas do técnico do $4^{\circ}$ Distrito, Armando Rebollo. As obras continuaram durante 1960 com a instalação da laje de concreto na área da entrada principal, que não foi coberta por terra, como proposto por Saia. Houve um consenso entre os técnicos e Loureiro de que a solução poderia prejudicar a estrutura pelo excesso de umidade. Alguns pontos necessitavam ser ainda discutidos.

Após a demolição das paredes externas que limitavam o terreno, foram descobertos os alicerces na parte frontal da antiga igreja, alicerces que por sugestão de Loureiro e Rebollo deveriam ser mantidos. ${ }^{41}$ Além disso, posteriormente foram encontrados os alicerces da parede lateral, limítrofe com o IHGP. A obra continuava em andamento no final de $1960^{42}$. Pelas fotografias enviadas por Loureiro, a parede da antiga igreja já estava sem reboco, já haviam construído a laje de concreto no acesso à porta principal e a retirada do material que ocultava as antigas alvenarias de pedra dos alicerces (Figura 22). No caminho seriam assentadas lajes de pedra doadas pela prefeitura e colocadas algumas peças de cantaria, vestígios da antiga igreja. $\mathrm{Na}$ vista para o claustro já estava instalado o guarda-corpo em madeira sugerido por Saia. Nas sugestões de Loureiro ficou clara a separação entre o Colégio e o IHGP através da colocação de uma cerca viva que delimitava os dois espaços.

\footnotetext{
${ }^{41}$ Carta de José Loureiro Fernandes a Rodrigo Melo Franco de Andrade em 27 de outubro de 1960. (Arquivo Central)

${ }^{42}$ Carta de José Loureiro Fernandes a Rodrigo Melo Franco de Andrade em 17 de dezembro de 1960. (Arquivo Central)
} 


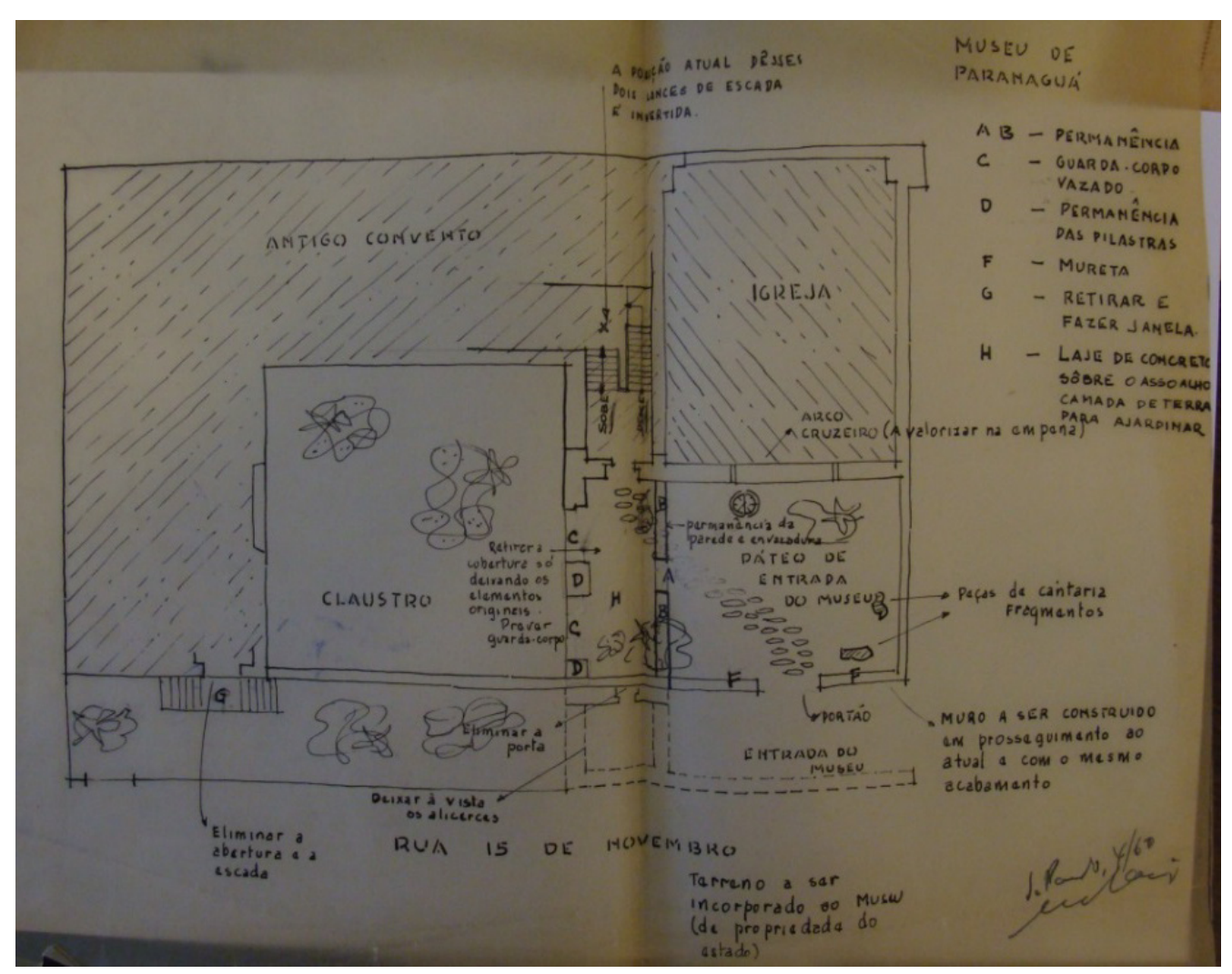

Figura 21:

Proposta para o novo acesso do museu apresentada por Luís Saia em abril de 1960. Fonte: Arquivo central do Iphan

Quando Luís Saia voltou à Paranaguá em março de 1961, sugeriu algumas alterações no projeto, uma delas se refere à entrada do IHGP que estava sediado no prédio ao lado, antes voltada para o jardim do museu. Saia propõe ao prefeito Joaquim Tramujas, que também é associado do IHGP, a mudança da entrada para a face oposta e define o tipo de vegetação a ser plantado no local. Pelo croqui encontrado no Arquivo Central, aparentemente existiria a comunicação entre os dois edifícios a partir do jardim:

Para evitar o pisoteio da parte ajardinada, se aconselhou o plantio de uma vegetação de espinhos junto à calçada. Para distinguir e evidenciar os restos do alicerce da torre se aconselhou fosse plantado no vazio destes alicerces um tipo de vegetação capaz de crear um desenho cheio; espadas de São Jorge. Nos pontos indicados pelo croquí, se aconselhou o plantio de bouganville de cores diferentes, permitindo seu crescimento livre. ${ }^{43}$

${ }^{43}$ Carta de Luis Saia a Rodrigo Melo Franco de Andrade em 9 de maio de 1961. 

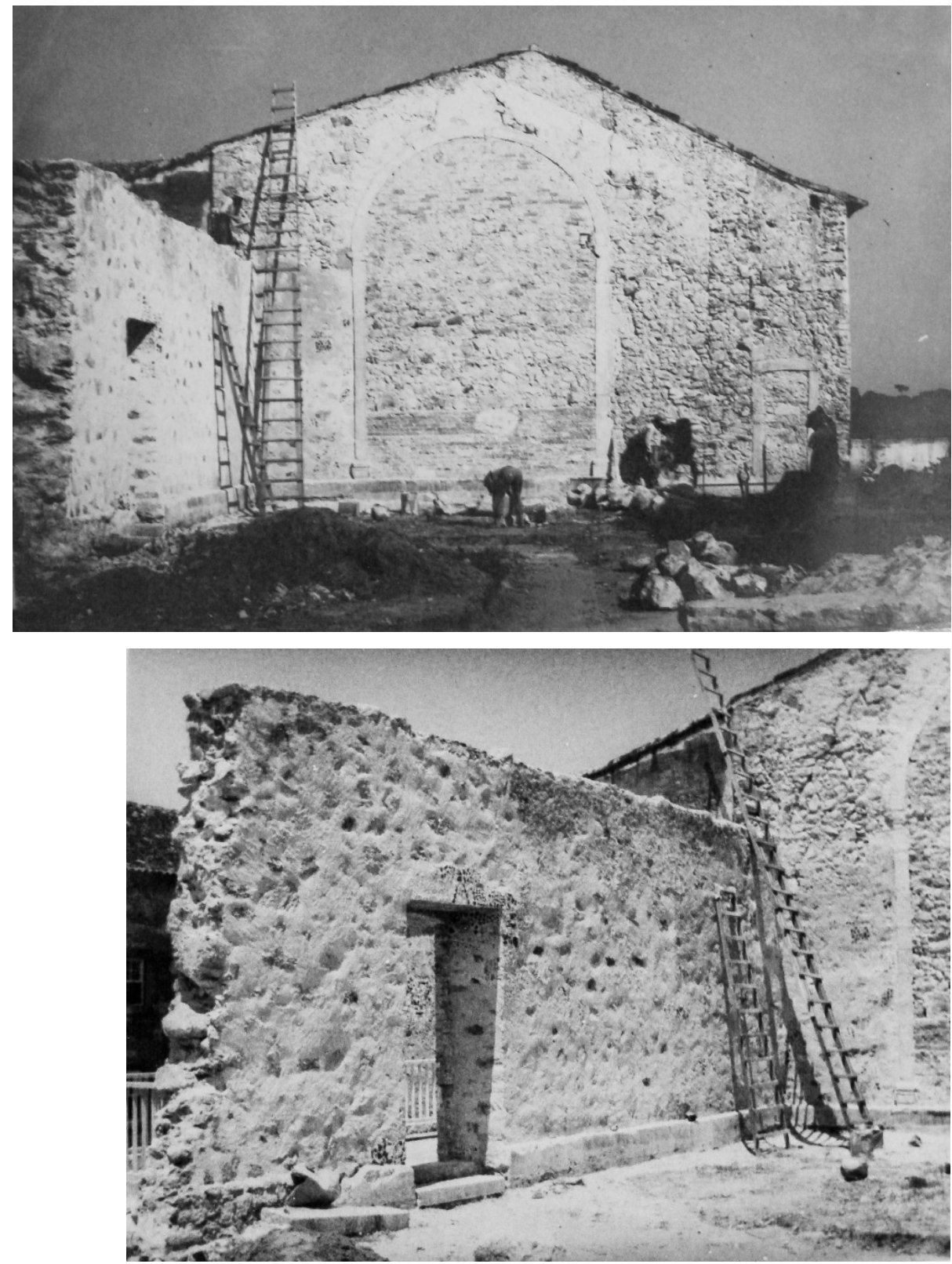

Figura 22: Imagens das obras em andamento, acima a parede de pedra e cal, ao centro as ruínas da antiga igreja, abaixo as ruínas da igreja e o edifício do IHGP.

Fonte: Arquivo Central do Iphan, 1960.

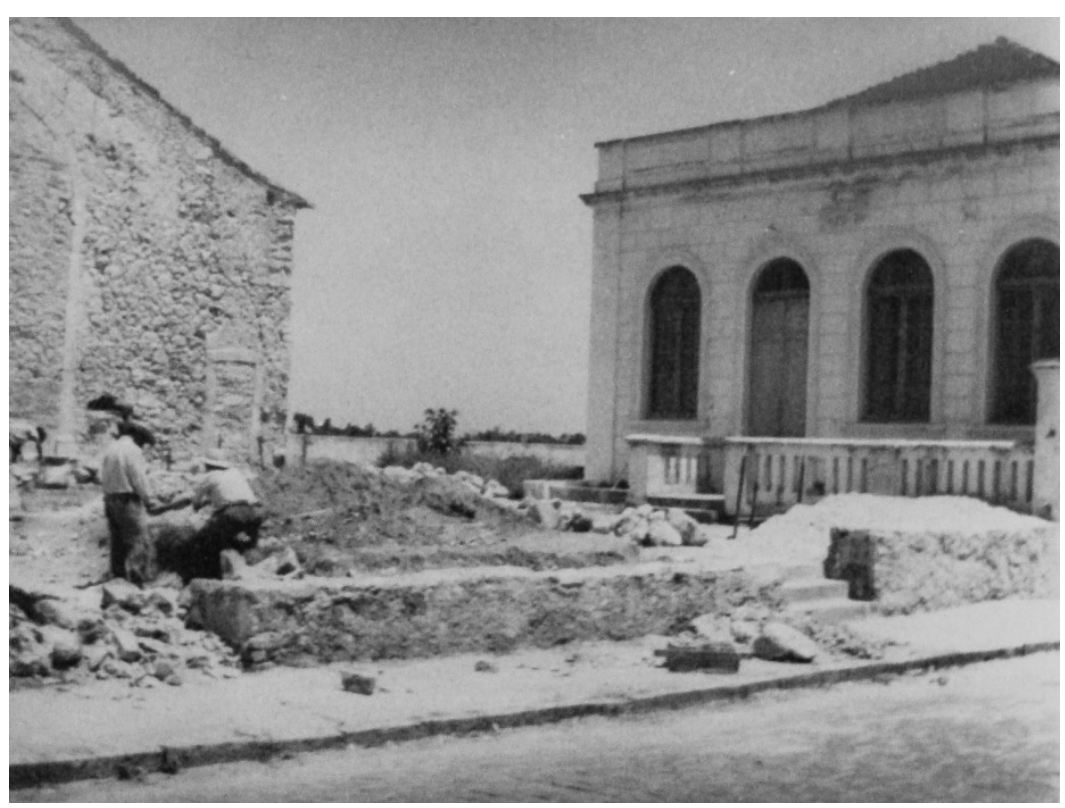




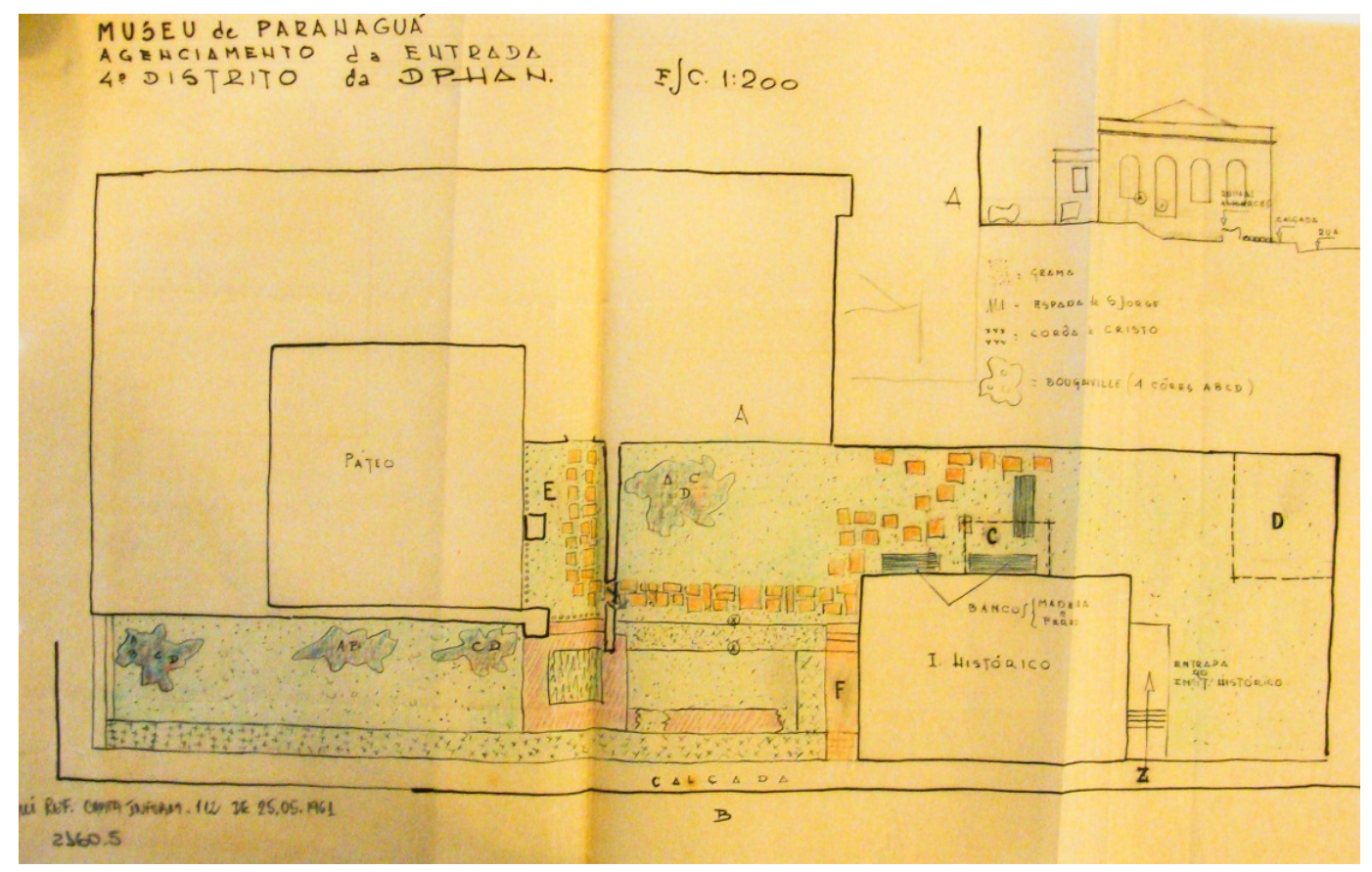

Figura 23: A segunda proposta de Luís Saia para o novo acesso ao museu em junho de 1961.

Fonte: Arquivo Central do Iphan.

Enquanto eram realizadas as obras de ajardinamento, em 30 de julho de 1961 o governador Ney Braga em conjunto com os professores da Universidade Federal do Paraná inaugurava as duas primeiras salas expositivas do museu, uma de arqueologia e outra de etnografia. ${ }^{44} \mathrm{~A}$ inauguração efetiva aconteceu em julho de 1963 após a preparação do acervo coletado nas mais diversas partes do país.

Analisando com mais cuidado a proposta de Saia, percebemos algumas características deste projeto que não eram comuns nas restaurações sob sua responsabilidade, uma ruína revelada a partir da retirada das alvenarias de tijolo que fazia parte do pequeno edifício oitocentista. Há uma atitude que elimina o que considerava espúrio, mas a partir disso expõe-se uma grande parede de pedra, retirando as adições e os revestimentos, revelando a estrutura antiga e lhe dando um caráter de deterioração. Parecia querer lembrar as palavras do grande teórico, John Ruskin em que:

[...] a maior glória de um edifício não está em suas pedras, ou em seu ouro. Sua glória está em sua Idade, e naquela profunda sensação de ressonância, de vigilância severa, de misteriosa compaixão, até mesmo de aprovação ou condenação, que sentimos em paredes que há tempos são banhadas pelas ondas passageiras da humanidade. (RUSKIN, 2008, p.68).

\footnotetext{
${ }^{44}$ Reportagem do jornal Diário do Paraná de 30 de julho de 1961.
} 
Seria uma atitude ruskiniana de Saia? Ou uma alternativa que permitisse dialogar com o claustro que também possui suas paredes expostas de pedra e cal? Infelizmente as justificativas para o restauro são muito sucintas e não revelam o embasamento teórico para as iniciativas, apenas o caráter de testemunho, um valor de antiguidade, isso pode ser avaliado pela justificativa de Saia sobre a manutenção dessa parede: “[...]pelo interesse que representa como vedação da área do pateo e como conservação de uma parede seguramente antiga." Seria como um registro, um testemunho da antiga igreja, ou apenas um objeto exposto como uma escultura, envolta por um gramado fazendo parte do promenade que daria acesso à entrada principal, limitada pelo calçamento em pedra (Figura 24).

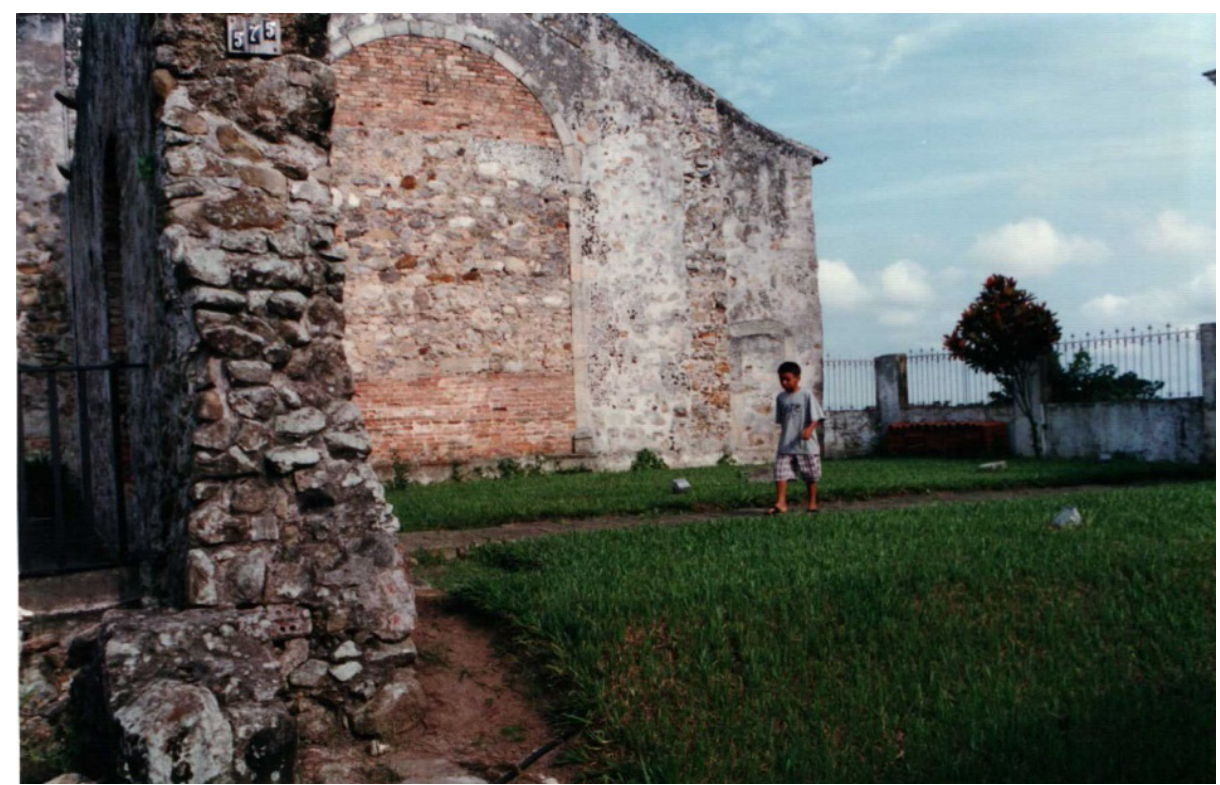

Figura 24: Alguns aspectos da ruína e sua interligação com o claustro do Colégio dos Jesuítas.

Fonte:

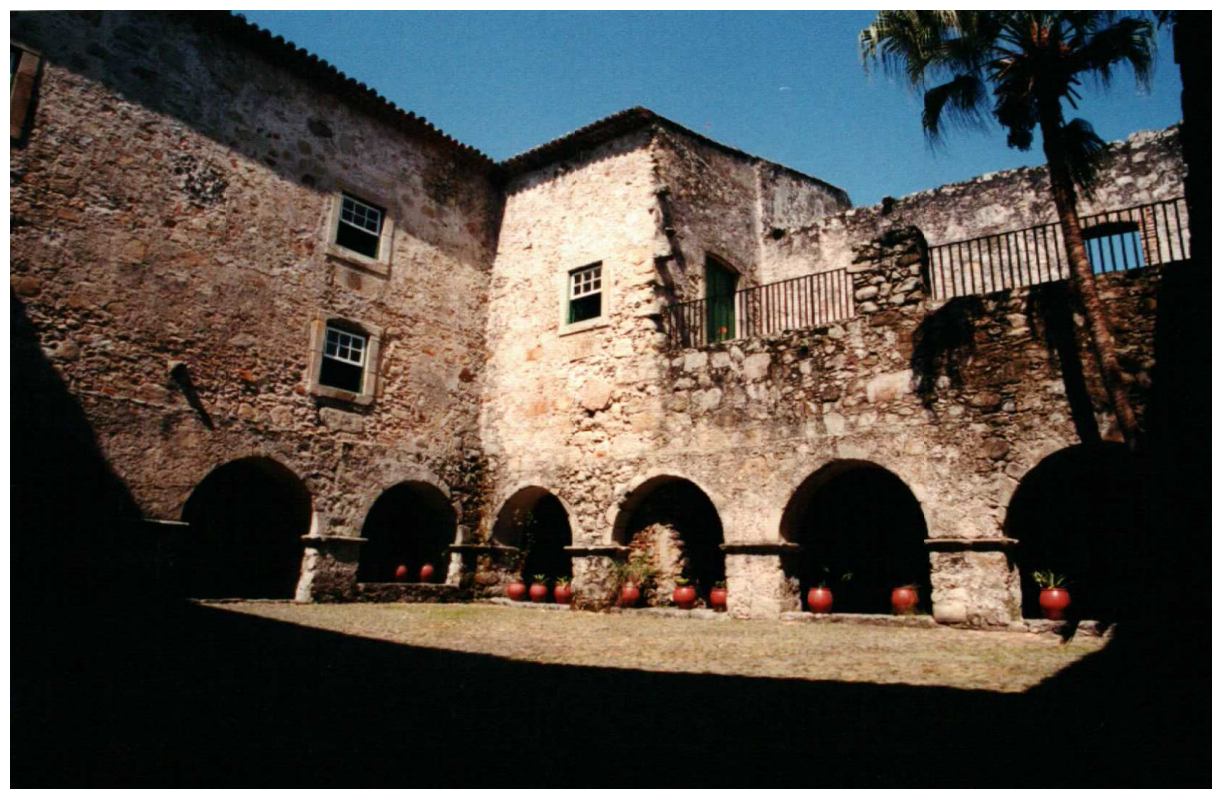

início dos anos 1990 
Como já vimos anteriormente, no primeiro relatório de Saia que contém a proposta para a restauração do Colégio Jesuíta regressamos à discussão das obras realizadas pelo arquiteto nas casas bandeiristas em que há constantemente a preocupação em eliminar as marcas do tempo e tratar de maneira à dar um aspecto de novo aos antigos edifícios. ${ }^{45}$

Mas sabe-se que muitas decisões projetuais eram definidas durante as obras, isso também se confirma pela falta de documentos precisos dos projetos elaborados para o museu. Há um trecho da tese de doutorado de Antônio Luiz Dias de Andrade (1992, p.1) que descreve os métodos de Saia na obra da Fazenda Pau d'Alho e que pode ilustrar essas tomadas de decisão durante o decorrer da restauração:

O projeto de Luis Saia foi sendo elaborado no canteiro de obras, no ritmo do desenvolvimento dos trabalhos, é certo, todavia, que a decisão de promover a restauração do bem cultural e o desejo de ali instalar o Museu Nacional do café compreenderam uma série de iniciativas paralelas como, por exemplo, a realização dos levantamentos métricoarquitetônicos de mais de uma centena de antigas fazendas na região, e que terminaram por influir na condução das obras na medida em que o conhecimento adquirido sobre a arquitetura do período foi se incorporando aos processos de trabalho.

Há também a ideia de equilíbrio na composição do edifício, muito ligada aos preceitos da arquitetura moderna, como aponta o arquiteto Cyro Correa Lyra que acompanhou e participou de muitas obras com Saia:

[...] há um caso por exemplo, que não interessa muito aí mas só pra você saber, quando eu restaurei o Forte de Santana, havia um elemento, um muro que o Luis Saia decidiu tirar o muro porque aquele pedaço de muro não era nada de muito extraordinário. Mas a razão pela qual ele tirava o muro era uma razão de um melhor equilíbrio na composição do Forte de Santana, essa coisa é do modernista, mas você tem isso também com a escola francesa, agora to dizendo isso respeitosamente, não to criticando o Saia, que eu acho que era um cara extraordinário, mas como era o pensamento dele. ${ }^{46}$

\footnotetext{
45 Vejamos exemplos como a Casa do Butantã ou a capela de São Miguel Paulista como já analisadas por Cristiane Gonçalves e Lia Mayumi.

${ }^{46}$ Entrevista realizada em 14 de agosto de 2012.
} 
Quanto ao uso dos materiais contemporâneos nesse projeto, por exemplo, o cimento armado sugerido pela Carta de Atenas de $1931^{47}$, não é evidente, foi apenas utilizado na construção da laje que dá acesso ao museu, o restante do projeto está potencializado na ambientação da ruína com a preocupação no ajardinamento e no tratamento do entorno com o uso da grama e da alteração do acesso do edifício vizinho do Instituto Histórico e Geográfico de Paranaguá, que faz lembrar o tratamento paisagístico que o arquiteto realizou no Sítio Santo Antônio, com a preocupação em reflorestar os morros ao fundo do conjunto e na construção de um lago à sua frente. Mas as ruínas da casa do Barão que faziam parte daquele complexo foram completamente eliminadas, e seria uma importante referência para o estudo da habitação daquele período, como analisa Cristiane Souza Gonçalves (2007, p131-132):

As ruínas da casa do barão, por outro lado, se tivessem sido mantidas constituiriam, hoje, o documento mais autêntico, preservado, do conjunto, onde talvez residissem as respostas aos questionamentos e hipótese com relação ao modo de vida paulista, desde o século XVII até o século XX, quando o conjunto foi encontrado.

Em seu lugar ficou a opção pelo viés moderno que substitui toda a aura de "tosquidão" e de ruína e, em seu lugar, a retidão, a pureza, a horizontalidade dos novos conceitos que inspiravam a construção dos modelos de referência.

São poucos os registros que esclarecem as etapas da restauração, desenhos são raros, as decisões são tomadas e relatadas pelas cartas, dificultando na percepção daquilo que foi alterado na restauração, como nas obras nas aberturas da fachada do Colégio voltadas para a Rua General Carneiro também conhecida por Rua da Praia. As alterações se concentram nas aberturas do térreo e do terceiro pavimento.

\footnotetext{
47 "Os especialistas receberam diversas comunicações relativas ao emprego de materiais modernos para a consolidação de edifícios antigos. Eles aprovaram o emprego adequado de todos os recursos da técnica moderna e especialmente do cimento armado." Carta de Atenas - Escritório internacional dos museus - Sociedade das Nações - Atenas, outubro de 1931. In: In: CURY, Isabelle (Org) Cartas Patrimoniais. $3^{\text {a }}$ Edição. Edições do Patrimônio: Brasília, 2004.
} 
As obras foram executadas entre janeiro e novembro de 1956 com o reforço da cobertura, limpeza das alvenarias, substituição de calhas, caiação, pintura das esquadrias, colocação de uma porta na fachada da Rua XV de Novembro e retirada de vergas de algumas janelas para substituição ${ }^{48}$. A retirada das vergas de janelas não está indicada com mais detalhes em nenhum documento, a partir das fotografias das obras que percebemos quais peças foram substituídas por vergas em concreto entre junho e julho de 1956, aparentemente já havia sido feito algum reparo na verga, dificilmente identificado pela falta de registros, mas pela fotografia poderia ter sido feito com uso de argamassa, pois percebemos a grande irregularidade da superfície que não agradou aos técnicos do Iphan. A nova verga de concreto ganhou um detalhe diferente de todas as outras, um trapézio no cimo do arco, algo que não encontramos na documentação justificativa nem proposta (Figura 25), além disso, o material não foi ocultado por nenhum tipo de revestimento, isso é de extrema importância, pois a dissimulação dos novos materiais foi recorrente nas restaurações da instituição, como as obras de restauro de Luís Saia em São Paulo. O que motivou a elaboração deste desenho no arco das duas janelas? Pois em nenhuma daquelas existentes encontram-se estas características. E porque o material não foi revestido?

Outro caso se refere as aberturas no térreo, as fotografias podem revelar mais detalhes que não constam na documentação. A partir das imagens dos primeiro levantamento de Erich Hess e comparando-as com o primeiro restauro, a fachada voltada para a Rua da Praia teve alterações visíveis no térreo, mais precisamente nas aberturas em que algumas portas acabaram se transformando em janelas (Figura 26 e Figura 27), que na justificativa de José Loureiro foi a maneira de proteger o acervo do futuro Museu. Anos mais tarde foram introduzidas barras de ferro nas janelas inferiores que se tornaram tão presentes no edifício a ponto de gerar muitas lendas sobre as antigas prisões no colégio contadas pelos parnanguaras. (FURTADO, 2006).

48 Boletim Mensal de Informações de junho e julho de 1956. 


\section{PARANAGUÁ: IDENTIDADE E PRESERVAÇÃO}

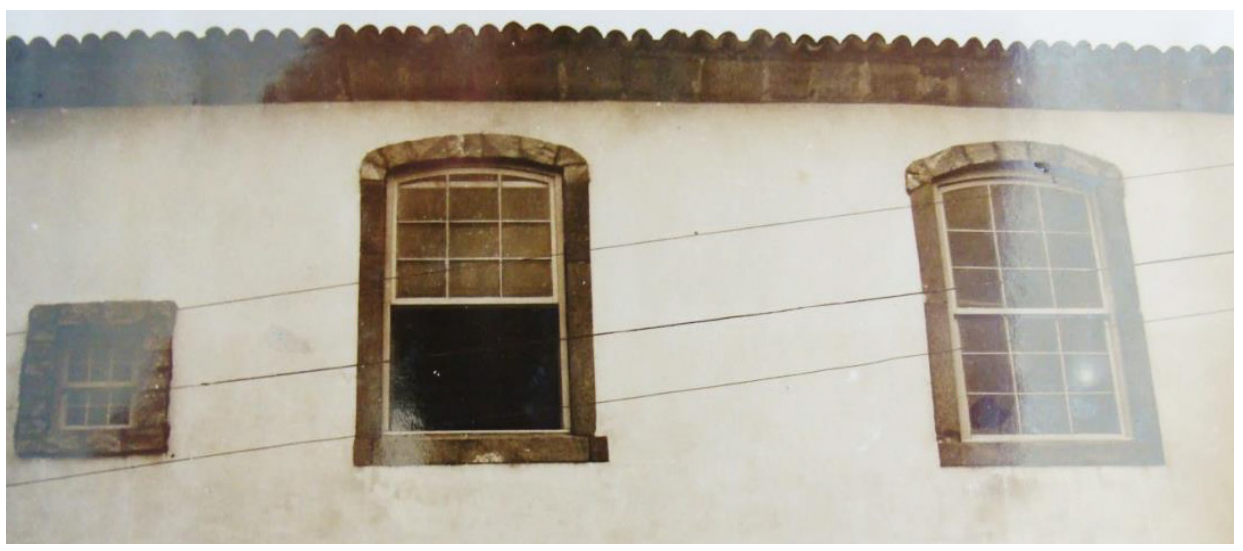

Figura 25: As duas janelas da fachada voltada para o rio Itiberê, apresentam em suas vergas no ano de 1956 ao que parece cobertas por

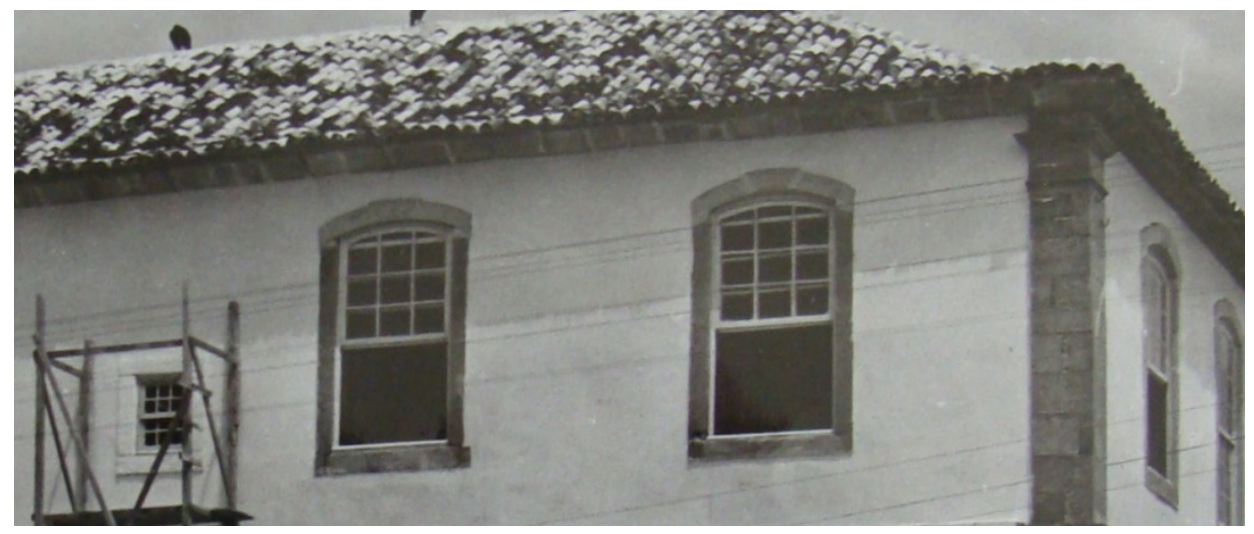
argamassa, em 1958 as vergas foram substituídas por concreto com desenho diferente das demais, $\mathrm{e}$ na última imagem em 2013.

Fonte: Fotografias sem autoria do Arquivo Central de 1956 e 1958; JABUR, 2013.

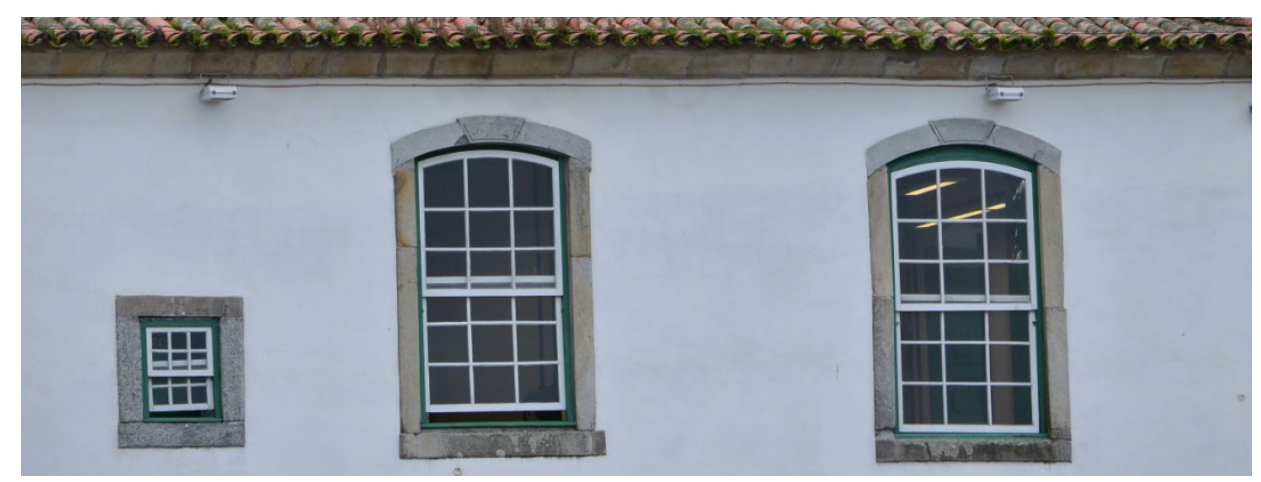

Figura 26: Vista do Colégio a partir da rua da Praia Fonte: HESS, Eric, Década de 1940, Arquivo Central do Iphan

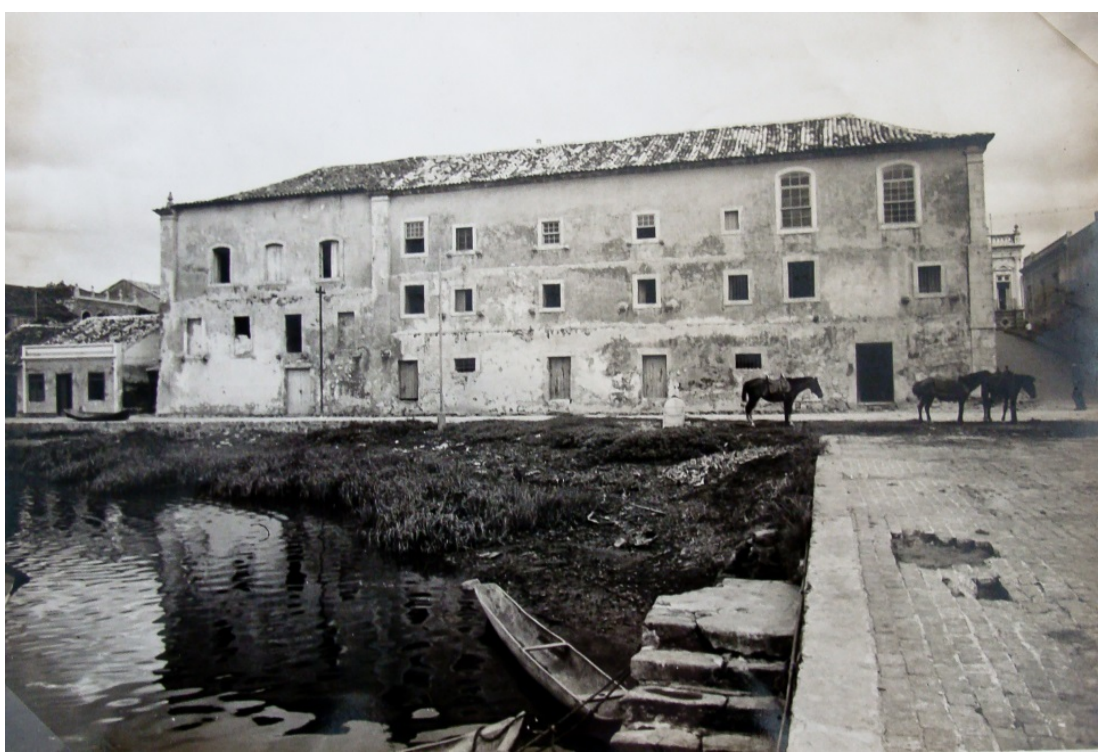




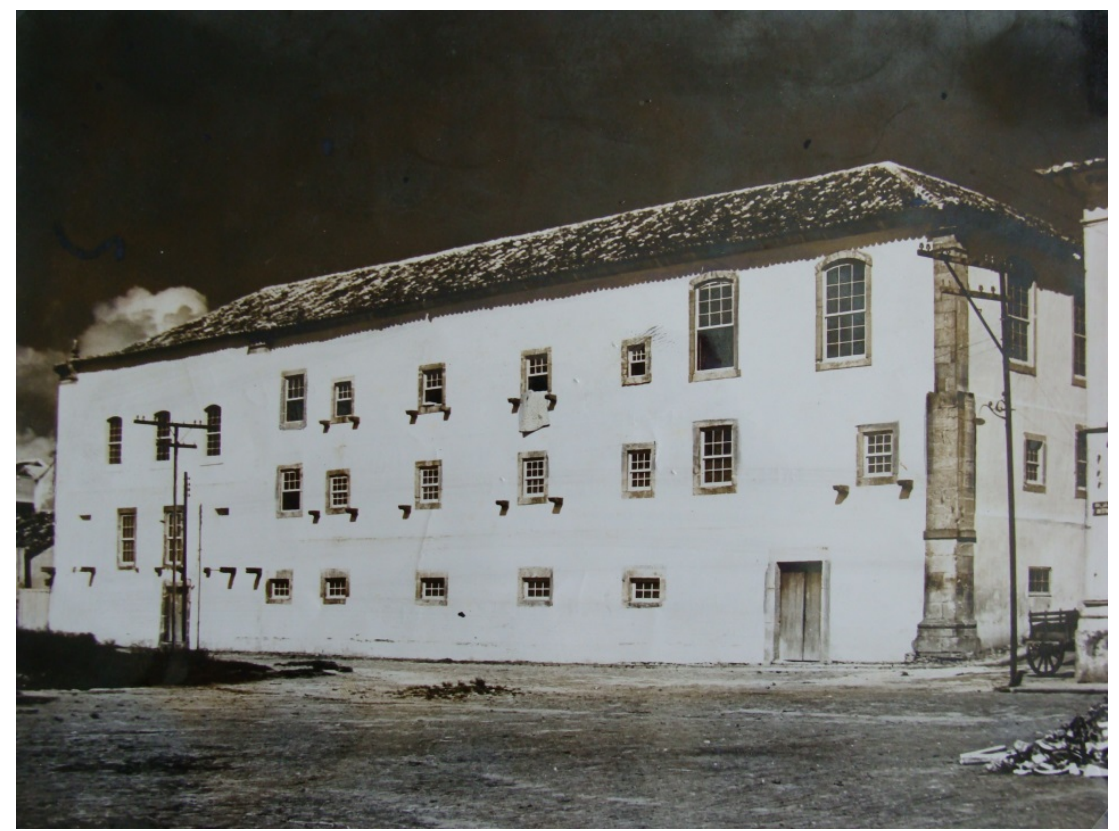

Figura 27: Fachada do Colégio a partir da rua da Praia após a primeira fase da restauração Fonte: sem autoria, 1/11/1953 Arquivo Central do Iphan.

Apesar das dúvidas existentes quanto à autoria e justificativa destas propostas, consideramos que são alterações importantes que acabam por descaracterizar parte da fachada, criando simetria a um edifício que sofreu ampliações depois da saída dos jesuítas e que possui aberturas nas mais variadas dimensões, uma característica marcante é a própria irregularidade das aberturas. Se isso foi permitido, porque a colocação de uma placa para indicar o museu não foi autorizada pela central carioca?

A proposta para a instalação de uma placa no edifício, para indicar o novo uso, provocou uma decisão negativa pela Central. A decisão escrita por Rodrigo nos permite analisar qual a justificativa e em que estavam embasadas suas decisões nas questões de projeto nos edifícios tombados:

Em suma, o fundamento do parecer desfavorável dos técnicos da DPHAN a algumas propostas e alvitres visando à conveniência dos serviços do futuro museu de Arqueologia e Artes Populares consiste na necessidade da preservação das características do monumento arquitetônico que é o antigo Colégio dos Jesuítas de Paranaguá. De fato, a utilização de monumentos de arquitetura antiga à finalidade de museu impõe certo número de restrições importantes à respectiva instalação, restrições essas que precisam estar sempre presentes no espírito dos responsáveis por seu funcionamento. Assim é que as sedes dessas instituições não poderão jamais se compatibilizar, externa e internamente, com iniciativas susceptíveis de alterar-lhes as peculiaridades originais ou prejudicar a aparência de sua destinação primitiva. Por esse motivo, tanto o Museu Imperial, quanto o Museu da Inconfidência, o do Ouro, o do Diamante e os demais, instalados em edifícios de valor histórico ou arquitetônico, não ostentam placas nas 
fachadas, nem sofreram em sua disposição interna modificações substanciais para corresponder à sua finalidade atual. ${ }^{49}$

A negativa sobre a proposta de Loureiro nos aponta sobre o caráter de originalidade tão difundido pelos técnicos da instituição, originalidade não apenas nos aspectos externos mas que também competem aos espaços internos, que a partir dos estudos difundidos, principalmente pelas revistas do patrimônio, nos apresentam a análise e a criação de certos "padrões" das edificações do período Colonial, o que acarretava na compreensão de seu uso original. Mas que originalidade é esta? Foi esse ideário de originalidade que permitiu que no antigo Colégio fossem apagadas todas as evidencias dos usos pela Alfândega de Paranaguá e pelos militares, como a retirada das celas e grades das prisões. Essa prática é analisada por Márcia Chuva (2009, p.326) que aponta a busca pelo caráter original propagado pelos técnicos da instituição:

Visando a conservação do patrimônio tombado, o Sphan investiu nos sentido da sua restauração. Para recuperar à nação a posse ou o domínio das suas origens, o patrimônio deveria manter-se e/ou voltar ao seu estado primitivo, devolvendo à nacionalidade um vigor perdido. As práticas de conservação do patrimônio tombado, que se rotinizaram dentro do Sphan, buscaram recuperar, física e simbolicamente, as origens da nação, promovendo, desta forma, a reconstituição de um patrimônio "original", "autêntico" e "primitivo", "genuíno". Esse vocabulário pertencente aos códigos desse novo discurso, presente em todos os casos analisados, que teve na Seção Técnica o lugar central de sua formulação.

Mas a originalidade também justifica a alteração dos vãos da fachada e a instalação de grades em benefício à segurança do museu? Pois não houve nenhuma objeção dos técnicos envolvidos. Neste caso as justificativas não são de ordem estética ou de composição, mas de uso. Não podemos comparar, por exemplo, com a reforma do Cine Vila Rica em Ouro Preto (1957), de autoria de Lucio Costa, que alterou completamente a fachada de características ecléticas para transformá-lo em um edifício de beiral e telha portuguesa com a justificativa, segundo Lia Motta (1987, p.110) de "[...] restabelecer a marcante linha de beirais da cidade ou, de forma mais radical, para eliminar o aspecto bastardo daquelas edificações." Ou no

${ }^{49}$ Carta de Rodrigo Melo Franco a José Loureiro Fernandes em 23 de julho de 1959. (Arquivo Central). 
caso da casa de Câmara e Cadeia de Atibaia, projeto de Luís Saia que foi realizada sem muitos levantamentos da estrutura do edifício, partindo da retirada de grande parte das ornamentações. (GONÇALVES, 2007).

Outro exemplo se refere a restauração anterior à solução de Luís Saia para a ruína da antiga Igreja. Na parte voltada para a rua XV de Novembro as alterações mais visíveis são identificadas no pequeno edifício contíguo na lateral onde antes estava a Igreja e que tinha por característica principal a platibanda, adquirida provavelmente em fins do século XIX. A restauração do edifício em 1958 optou pela anulação do elemento como partido que já era difundido pelo patrimônio, dessa maneira igualando o anexo com as características do resto do edifício. $\mathrm{Na}$ outra extremidade da fachada da rua XV de novembro o pequeno alpendre de madeira situado no segundo acesso foi retirado e uma nova escada foi construída, agora em pedra (Figura 28). Duas soluções contrastantes, uma que mantem o anexo com mesma linguagem do edifício e outra que apresenta uma ruína, ambas foram aprovadas pelo Serviço do Patrimônio.

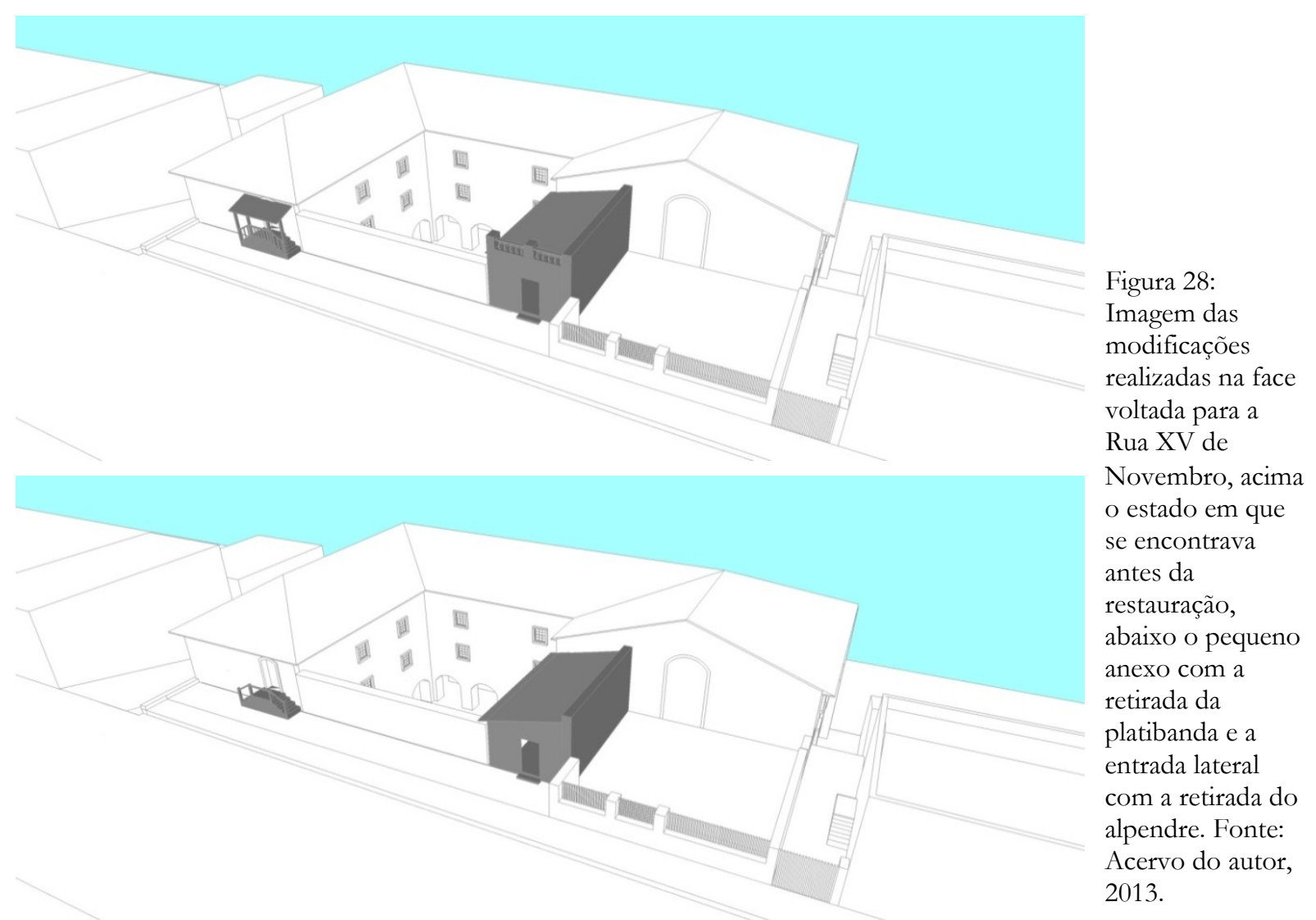


Estas soluções podem nos apontar para as teorias de Viollet-le- Duc, que em alguns projetos utiliza do "estilo" para a solução de um problema funcional, como comenta Carbonara (2010) no exemplo de uma nova escada que dava acesso a nave lateral de uma igreja, o arquiteto em seus projetos não apenas restringia-se aos completamentos estilísticos. Viollet-le-Duc em seu texto Restauração exemplifica sobre o uso dos edifícios, distinto daquele que fora destinado, um antigo refeitório que se torna biblioteca, para isso "[...] o melhor a fazer é colocar-se no lugar do arquiteto primitivo e supor aquilo que ele faria se, voltando ao mundo, fossem a ele colocados os programas que nos são propostos." (VIOLLET-LE-DUC, 2013, p.64).

As contradições são tão presentes nas discussões sobre as propostas para o museu no antigo Colégio, que Luís Saia, durante o primeiro restauro, coordenado por Eugênio Contin, discutiu a demolição total do pequeno anexo ao lado da igreja (Figura 29). Nessa carta Contin alegou a impossibilidade de reconstrução da igreja a partir das ruínas. $\mathrm{Na}$ área em que possivelmente existia a capela-mor e a sacristia, que ele alega serem construções do século XIX, constatação justificada pelo recuo da parede do terceiro piso na fachada voltada para a Rua da Praia e pelas janelas em verga arqueada, Contin e Saia possuíam soluções diferentes ${ }^{50}$ :

É de meu parecer que se deveria conservar aqueles acréscimos, dando-se, evidentemente, um aspecto idêntico ao resto do prédio. [edifício lateral à antiga parede da igreja]

Mas, será esta também a opinião dessa Diretoria?

Consta que o Dr. Saia é mais pela demolição, não só dos acréscimos, mas também de todo o corpo situado na área (II) [Espaço aos fundos da ruína da antiga igreja].

${ }^{50}$ Carta de Carlos Contin a Rodrigo Melo Franco de no 1044/50 em 13 de agosto de 1950. (Arquivo Central) 


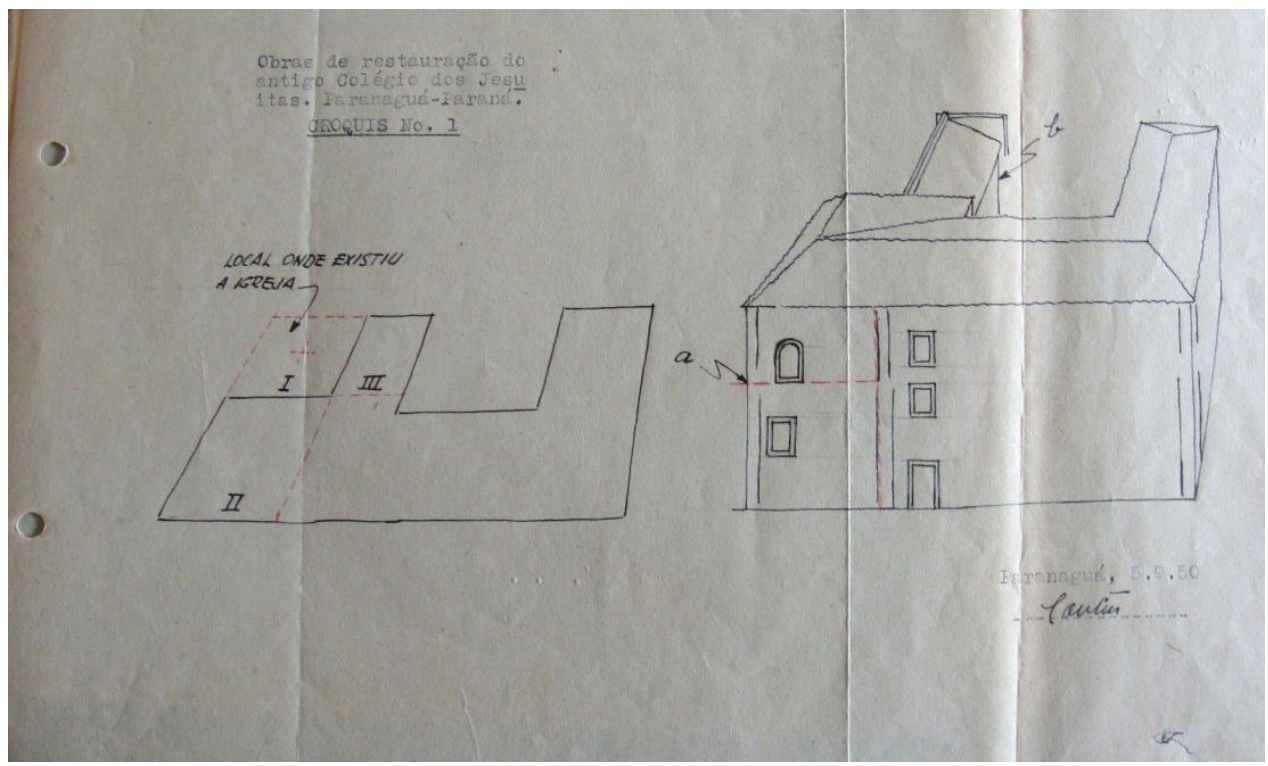

Figura 29: Croqui de Carlos Contin que complementa a carta sobre as propostas de restauro no Colégio Jesuíta, como a demolição da área da fachada demarcada com o item a.

Fonte: Arquivo

Central do

IPHAN

Contin e Saia tinham divergências quanto à solução para as fachadas do edifício; o próprio discurso de Saia mudou drasticamente desde a primeira proposta de julho de 1948, de uma atitude de apenas limpar e conservar o que fosse necessário, para a retirada de grande parte dos acréscimos e em alterações na fachada na busca da "originalidade". A mudança de soluções seria por questões financeiras? Apesar de estar em sintonia com os ideais defendidos pelos técnicos do patrimônio, ainda era necessária a consulta à central e não à D.R paulistana, de maneira geral nessa primeira fase de restauração, a comunicação acontecia entre o técnico do Paraná e os técnicos do Rio de Janeiro que emitiam o parecer final. Essas informações não foram respondidas rapidamente já que o IPHAN não possuía dados suficientes para a análise, esse evento demonstra a dificuldade que existia na organização e comunicação entre a Central e a direção do Distrito paulista, pois o levantamento já estava arquivado no $4^{\circ}$ Distrito, mas entre a solicitação e o envio do material foram quase três meses.

Outro ponto relevante nas obras foi a decisão sobre o acesso e usos dos espaços do Museu. Já se cogitava pelo Governo do Estado o uso do Colégio como sede para o Instituto Histórico e Geográfico de Paranaguá, paralelamente aos estudos de José Loureiro para a formação de um museu etnográfico no mesmo 
edifício. Próximo do término das obras, Rodrigo Melo Franco enviou para o Presidente do IHGP, Joaquim Tramujas, um termo de entrega e recebimento do edifício do Colégio e apontava para o local de instalação da sede do Instituto em local discreto, pois as principais salas deveriam ser utilizadas para exposições do museu $^{51}$. Logo após o término das obras, houve a necessidade de se indicar em Paranaguá alguém, ou alguma instituição, que se tornaria responsável pelo edifício. Apesar do termo já ter sido assinado anteriormente, já existia uma atividade política ligada ao Presidente do IHGP, Joaquim Tramujas, junto ao Governo do Estado e à Câmara de Paranaguá para garantir-lhe a entrega das chaves. O Presidente da Câmara Nelson Buffara encaminhou à direção do IPHAN uma carta solicitando informações sobre o término das obras e quando "[...] será devolvido à guarda do município com finalidade que se possam criar providências para crear-se naquele próprio o Museu de Paranaguá." 52

A entrega das chaves para Tramujas aconteceu em 17 de novembro de 1956, a partir da indicação do Diretor de Cultura da Secretaria de Educação do Paraná Guido Arzua ${ }^{53}$. José Loureiro Fernandes foi contrário a entrega como explica em carta a Rodrigo Melo Franco:

Será um desastre se o Museu for montado por pessoas alheias aos atuais problemas de Museologia. Ao Dr. Tramujas, foi determinada a entrega do prédio pelo Secretário ao Dr. Mauricio que ontem esteve aqui. Assegura-me o Secretário que é simplesmente para atender e controlar o zelador, mas estou um pouco inquieto, pois, já houve preocupação de divulgar pela imprensa a atribuição do Dr. Tramujas, aliás com quem me dou muito, boa pessoa mas com pontos de vista muito limitados no problema dos Museus, ao mesmo tempo que muito preocupado com o modesto Instituto Histórico de Paranaguá. ${ }^{54}$

Também contrário à ação, o diretor do Museu Paranaense Julio Moreira se manifestou ao Governador do Estado solicitando que a responsabilidade sobre a

\footnotetext{
51 Carta de Rodrigo Melo Franco para Joaquim Tramujas em 14 de janeiro de 1956.

${ }^{52}$ Carta de Nelson Buffara a Rodrigo Melo Franco em 14 de junho 1956. (Arquivo Central).

53 Carta de Guido Arzua a Renato Soeiro em 6 de novembro de 1956. (Arquivo Central).

${ }^{54}$ Carta de José Loureiro Fernandes a Rodrigo Melo Franco em 16 de novembro de 1956. (Arquivo Central).
} 
montagem do museu estivesse a cargo da Secretaria de Cultura que se propõe a criar um museu de artes e tradições populares ${ }^{55}$.

O tema das tradições e artes populares não era de interesse dos associados do IHGP, sua proposta para a criação do Museu de Paranaguá era de reunir peças e documentos relacionados às tradicionais famílias da cidade, expondo aquilo que representava a chamada tradição. Isso é evidenciado nas reuniões estabelecidas pelo IHGP antes da entrega das chaves do Colégio, nas reuniões dos associados já eram discutidas as propostas para a criação do museu e na obtenção de peças para as exposições que ficaram à cargo de Manoel Vianna como descrito em ata:

O prof. Manoel Vianna, fazendo uso da palavra, faz sentir a necessidade da coleta de objetos e documentos de valor histórico para o projetado Museu, propondo-se a trabalhar nesse sentido junto as famílias paranaguenses que em regra são possuidoras de objetos antigos, retratos interessantes e documentos igualmente interessantes dos arquivos familiares e sempre relacionados com a vida social da Paranaguá doutras épocas, pois pensa encontrar em todas a melhor vontade em cedê-los para o Museu onde serão conservados, evitando a dispersão e a perda total. (IHGP, 1956, p. 43-44)

O impasse pela decisão sobre o uso do edifício trouxe o reitor da Universidade Federal do Paraná, Flávio Suplicy de Lacerda ao Rio de Janeiro para, de forma estratégica, buscar apoio da Diretoria de Ensino Superior e do Iphan em prol da montagem do museu. Pela proposta apresentada seria criado além do Museu, um Instituto de Pesquisas e dessa forma no final de 1957 já havia a negociação para um acordo de cooperação entre a universidade e o novo Museu em Paranaguá. ${ }^{56}$

$\mathrm{Na}$ realização da vistoria ao edifício do Colégio pelo técnico Edgar Jacintho em dezembro de 1957, ficou claro que a proposta do Museu de Tradições Populares estava definitivamente resolvida e no pavimento ao nível da rua XV de Novembro haveria a divisão entre os usos do Instituto de pesquisas e o IHGP que já ocupava o prédio desde janeiro do mesmo ano, pela proposta o IHGP ocuparia

\footnotetext{
${ }_{55}$ Carta de Julio Moreira ao governador Moisés Lupion em 19 de novembro de 1956. (Arquivo Central)

${ }^{56}$ Carta de José Loureiro a Rodrigo Melo Franco em 9 de dezembro de 1957. (Arquivo Central)
} 
apenas uma sala que estava situada na área do pequeno anexo situado ao lado da antiga igreja, já o auditório seria de uso tanto da instituição parnanguara como do centro de pesquisas e do museu, entre as alas haveria uma divisória que serviria para resguardar objetos e evitar a presença de pessoas estranhas ao Instituto de pesquisas, também evitava o contato com as atividades do IHGP pois os acessos para as duas alas eram independentes

Mas o que de fato ocorreu foi que o IHGP se apropriou de três salas do Colégio e montou uma exposição no início de 1958, dando ampla divulgação de que seria em breve aberto o Museu de Paranaguá, essa atitude foi mais um ponto de desgaste entre as instituições. Sabendo dessa notícia, Loureiro pediu urgência na criação do convênio entre o Iphan, a Diretoria de Ensino Superior e a Universidade do Paraná para evitar a inauguração do Museu de Paranaguá ${ }^{57}$. Dessa maneira, o convênio foi firmado em 17 de julho de $1958^{58}$ criando o Museu de Arqueologia e Artes Populares, que seria organizado pela Universidade do Paraná e pelo Instituto de pesquisas criado por Loureiro. Quanto ao IHGP, pelo acordo, a instituição poderia ocupar apenas uma dependência do prédio e utilizar quando necessário o auditório do recém-criado museu. Dois dias após o convênio, Rodrigo Melo Franco solicitou ao presidente do IHGP Joaquim Tramujas a devolução das chaves. $^{59}$

A partir daí Loureiro participou intensamente das obras de adaptação para o museu, obras que se referem ao mobiliário e pequenos ajustes no edifício. Além disso, Loureiro já estabelecia contatos com universidades estrangeiras e a vinda de pesquisadores à Paranaguá, também enviou Oldemar Blasi para os Estados Unidos com o intuito de recolher informações e aspectos dos museus de arqueologia daquele país.

Um dos itens preocupantes se refere ao auditório, localizado aos fundos da ruína da antiga igreja, essa área era um grande salão tornava-se necessário o reforço

\footnotetext{
${ }^{57}$ Carta de Loureiro Fernandes à Rodrigo Melo Franco em 14 de janeiro de 1958. (Arquivo Central)

${ }^{58}$ Convênio entre a Reitoria da Universidade do Paraná e a Diretoria do Patrimônio Histórico e Artístico Nacional, para instalação do Museu de Paranaguá, em 17 de julho de 1958. (Arquivo Central)

${ }^{59}$ Carta no 968 de Rodrigo Melo Franco a Joaquim Tramujas em 19 de julho de 1958. (Arquivo Central)
} 
das vigas de madeira para suportar um numero maior de pessoas naquele espaço. Apesar da recente restauração, já eram identificados alguns problemas que possivelmente foram decorrentes das irregularidades das obras acompanhadas pelo engenheiro Contin, destaca-se o ataque de cupins nos assoalhos e a ferrugem das peças metálicas. ${ }^{60}$ Houve o reforço do vigamento do auditório, a instalação das divisórias internas de madeira, limpeza das pedras de soleiras e das conversadeiras das janelas, lixamento dos assoalhos e substituição de peças atacadas por cupim. Houve sempre o apoio do prefeito Cominese que acompanhou as obras e as visitas dos técnicos.

Quanto aos acessos, o principal ainda era situado ao lado direito na fachada fronteira ao Itiberê, que posteriormente foi alterado quando da descoberta das ruínas no jardim voltado para a Rua XV de Novembro. Em 10 de abril de 1959, Alfredo Rusins em companhia de José Loureiro realizou mais uma vistoria no museu e aproveitou para discutir sobre as circulações e áreas expositivas. Segundo seu relatório, o pavimento ao nível da rua XV de Novembro seria de uso administrativo, do auditório e de moradia do secretário do museu. O segundo pavimento abrigaria as áreas de exposição com os temas da arqueologia brasileira, arqueologia geral e etnografia brasileira sendo a transição das técnicas arqueológicas para as técnicas populares. No térreo seriam instalados o engenho de açúcar e um carro de boi, o material seria coletado no decorrer dos anos. ${ }^{61}$

As cartas pesquisadas nos arquivos das instituições possibilitou estabelecer uma narrativa da restauração do Colégio dos Jesuítas de Paranaguá, desde as sondagens de Rodrigo Melo Franco de Andrade, a primeira seleção de David Carneiro e o efetivo tombamento federal. A relação antes estabelecida por cartas e telegramas foi se estreitando com a vinda dos técnicos de São Paulo e Rio de Janeiro para Paranaguá, atraídos não só pelas obras do antigo Colégio, mas também na busca de outras edificações que pudessem constar na lista de bens tombados. Mas, a vinda dos técnicos tornou-se mais frequente e as propostas para a

\footnotetext{
${ }^{60}$ Carta n ${ }^{\circ} 74 / 58$ de José Loureiro a Renato Soeiro em 8 de outubro de 1958. (Arquivo Central)

${ }^{61}$ Relatório de Alfredo Rusins de abril de 1959. (Arquivo Central)
} 
restauração mais complexas a partir do envolvimento de José Loureiro Fernandes na criação do novo Museu sediado no antigo edifício.

A insistência de Loureiro e seu cuidado na condução das obras, apesar de não ser nem arquiteto, nem engenheiro, mas médico de formação, demonstra que a estreita relação estabelecida com Rodrigo Melo Franco de Andrade e a importância que dava à instituição, convidando seus representantes para os eventos comemorativos no Paraná, possibilitou que o Colégio dos Jesuítas não estivesse fora das preocupações dos técnicos do IPHAN e inseriu Paranaguá no mapa do patrimônio nacional.

A questão dos acessos do Colégio para a criação do Museu e a proposta de Luís Saia nos faz refletir sobre os critérios estabelecidos para intervir no edifício, desde a primeira proposta de intervenção mínima, até a demolição como procedimento para revelar uma antiga ruína. Mudanças de postura que suscitam questionamentos. Seriam justificadas apenas pelos critérios econômicos? Lançamos a seguinte suposição: A descoberta dos antigos alicerces da igreja a partir das escavações de Loureiro e a "criação" de uma ruína da antiga parede lateral da igreja jesuíta seria resultante do próprio caráter do novo Museu, de arqueologia e do papel de Loureiro. O professor seria uma influência para a proposta de Saia?

Percebemos que em toda a trajetória de criação e instalação do Museu de Arqueologia as propostas de restauração estavam ainda em experimentação pelos técnicos do IPHAN, veja as inúmeras soluções adotadas que não possuem semelhanças ou relações: vergas em concreto armado, alterações em aberturas por questões de segurança, a criação de uma ruína, são soluções distintas que demonstram a complexidade dessas propostas e a dissonância entre as instâncias, as dúvidas surgem pelas ausências de documentação e de registros precisos sobre as soluções adotadas. A única certeza é que foram chanceladas pelos técnicos do IPHAN. O Colégio é um exemplo destas incertezas e dos procedimentos que marcaram a primeira fase de obras de restauro proporcionadas pelo IPHAN, não podemos afirmar que neste caso houve um procedimento padrão, mas uma série de 
propostas e experiências. Nas restaurações empreendidas nas décadas posteriores percebemos o uso de referenciais de outros monumentos restaurados, veremos no próximo capítulo com o caso das igrejas da Ordem Terceira de São Francisco das Chagas e de São Benedito. 

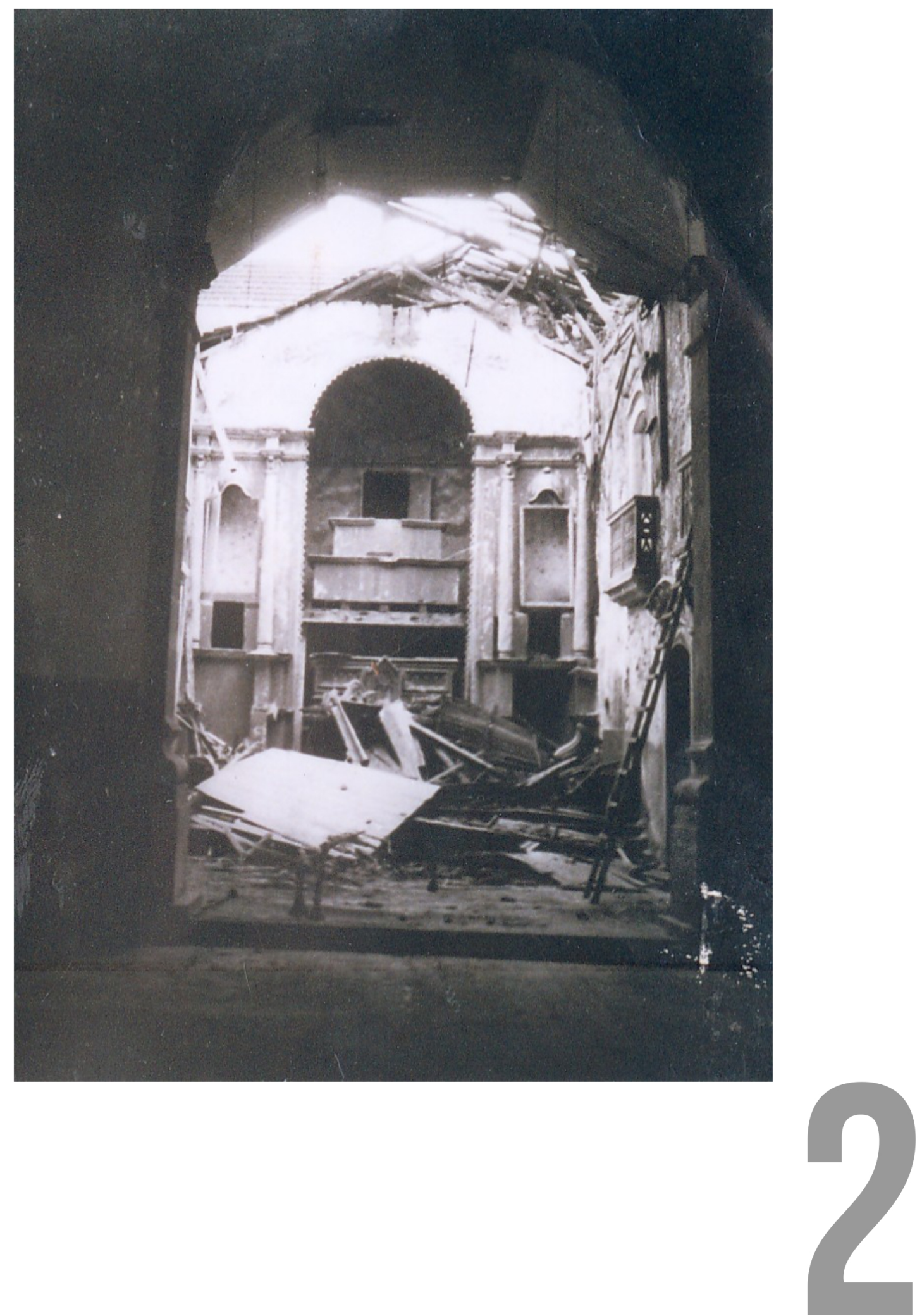



\section{CAPÍtUlo 2. CONFLITOS E DISPUTAS NA CONSERVAÇÃo Do PATRIMÓNIO PARNANGUARA}

Paranaguá possuía até 1965 apenas um edifício urbano tombado pelo IPHAN. Apesar do expressivo número de tombamentos de edifícios religiosos, nas primeiras décadas de atividades da Instituição, como já é apontado na bibliografia sobre o tema, as solicitações das igrejas de São Benedito, de construção iniciada em 1784, e da Ordem Terceira de São Francisco das Chagas, construída em 1794, não foram aprovadas nas primeiras tentativas. Estes edifícios obtiveram o tombamento resultante de conflitos e disputas gerados nas relações estabelecidas entre o Governo do Estado, a DR. paulistana e a Central carioca, ambas do IPHAN. É essencial analisarmos os dois casos para melhor compreender os meandros da preservação do patrimônio em Paranaguá e as redes de relações que permitiram finalmente o tombamento destas igrejas em 1965.

As duas igrejas tem diversas afinidades em seu processo de preservação, pois $\mathrm{o}$ interesse pelos monumentos e seu tombamento aconteceram conjuntamente, e também as primeiras restaurações na década de 1960. Portanto, propomos uma análise conjunta do processo de tombamento dos dois edifícios, através das cartas trocadas entre as instituições envolvidas. A análise dos projetos e a execução das obras de restauro serão discutidas na sequência.

Apesar de fazerem parte das fichas do Paraná, elaboradas por David Carneiro em 1938, as igrejas da Ordem Terceira e de São Benedito não obtiveram registro no livro do tombo e tão pouco foi possível localizar justificativas sobre esta decisão. Em 1951, houve uma segunda oportunidade, a partir da proposta do prefeito João Eugênio Cominesi, para o tombamento das duas igrejas pelo Serviço 
do Patrimônio. ${ }^{62}$ Comparando com a primeira proposta, os procedimentos para o tombamento tornaram-se mais especializados, em decorrência das mudanças administrativas de 1946, que estabeleceram os departamentos técnicos e suas especialidades. Nas cartas trocadas entre os técnicos é possível observar claramente a maneira como os pedidos eram encaminhados ${ }^{63}$.

O interesse pelo tombamento das duas igrejas se deu a partir da Prefeitura Municipal, que fez a primeira solicitação. Márcia Chuva (2009), quando analisa as relações entre o IPHAN e as municipalidades durante os anos de 1930 e 1940, aponta que os conflitos entre as referidas instâncias decorriam principalmente do desinteresse dos municípios em preservar seu patrimônio histórico, com a justificativa de que o registro prejudicava o progresso das cidades. Ainda segundo Márcia Chuva, dos vários meios que o IPHAN utilizava para resolver o problema, um dos principais estava na influência de autoridades superiores, que de certa maneira pressionavam os representantes municipais para a resolução do impasse. Em Paranaguá ocorreu exatamente o contrário e é importante destacar que houve neste período um declarado interesse da municipalidade, tornando-se por esta razão um caso relevante no panorama da história da preservação do patrimônio brasileiro.

Por fim, após o envio da documentação referente ao monumento, a DCR, no papel de Edgard Jacintho da Silva, respondeu à DET, apontando a necessidade de complementar à documentação com mais imagens do interior da igreja, levantamento esquemático e "detalhes e peças de interesse artístico" ${ }_{64}$. De 5 a 15 de abril de 1952, Paulo Thedim Barreto esteve em Paranaguá e avaliou os edifícios, mesmo assim solicitou fotografias e desenhos das igrejas, de antemão considerou que a igreja da Ordem “[...]tem interesse local”" ${ }^{5}$. Mas é visível certa insegurança na decisão devido à falta de documentos para a análise, apesar do técnico do IPHAN

\footnotetext{
${ }^{62}$ Carta de João Eugênio Cominesi a Rodrigo Melo Franco em 6 de dezembro de 1951. (Arquivo Central)

${ }^{63}$ As cartas do processo de tombamento da igreja da Ordem e São Benedito apresentam pequenas notas escritas à mão que permitem revelar os passos pelos quais os departamentos encaminhavam e analisavam as propostas.

${ }^{64}$ Informação de 26/12/1952. (Arquivo Central)

${ }^{65}$ Relatório de Paulo Thedim Barreto de abril de 1952. (Arquivo Central).
} 
ter ido à Paranaguá, o levantamento de dados ficou a cargo do município ${ }^{6 .}$. Isso dá conta da importância que a documentação fotográfica possuía na análise e na decisão final do tombamento. Porém, analisando a justificativa dada por Barreto, esta seria uma maneira diplomática de modo a evitar desentendimentos com a prefeitura municipal, tentando amenizar um possível desinteresse dos técnicos pelas duas igrejas? Por que Paulo Thedim, quando esteve em Paranaguá, não colaborou com nenhum levantamento destes monumentos? Como não houve mais respostas por parte da municipalidade sobre o envio de novos dados, o processo acabou arquivado em 1962.

A análise de casos semelhantes nas atas do Conselho Consultivo do IPHAN, nos permitiu ampliar as discussões sobre o caso. Verificamos, por exemplo, situações em que o pedido partiu da sociedade civil, no caso de Cachoeira do Sul, no Rio Grande do Sul, houve a solicitação de tombamento pelo Monsenhor Armando Teixeira da catedral Nossa Senhora da Conceição: na reunião do Conselho Consultivo a maioria dos conselheiros não concordou com o pedido, mas aprovou a solicitação de informações pormenorizadas sobre as talhas e outras características internas do edifício que já fora reformado e possuía em sua fachada características ecléticas. Em 1962 em decisão definitiva, o Conselho Consultivo negou o tombamento [...] por ter sido gravemente desfigurada, de acordo com as conclusões do Relator." ${ }^{67}$.

Outro caso aconteceu em 1969 com o pedido de tombamento da igreja de São Francisco em Florianópolis, o conselheiro Paulo Santos considerou que a igreja deveria ser "[...]apenas inventariada, dando seu interesse como monumento regional.” ${ }_{68} \mathrm{O}$ parecer foi aprovado por unanimidade. Ou seja, na dúvida sobre o tombamento, novas informações eram solicitadas, não sendo suficientes aquelas restritas às características externas, é provavelmente o que aconteceu com as igrejas

\footnotetext{
${ }^{66}$ Cartas de Rodrigo Melo Franco a João Eugênio Cominesi em 3 de abril e 4 de junho de 1952. (Arquivo Central). ${ }^{67}$ Ata da $40{ }^{\text {a }}$ Reunião do Conselho Consultivo do Patrimônio Histórico e Artístico Nacional de 23 de outubro de 1962.

${ }^{68}$ Ata da $52^{\mathrm{a}}$ Reunião do Conselho Consultivo do Patrimônio Histórico e Artístico Nacional de 02 de setembro de 1969.
} 
de Paranaguá, dúvidas que devem ter sido motivo de discussões entre os técnicos do Serviço do Patrimônio e o pedido de mais informações, seja em fotos ou textos, foi recorrente nestes casos.

Por outro lado, a Matriz de Nossa Senhora do Montserrat em Baependi, em Minas Gerais, teve a solicitação de tombamento voluntário, a pedido da Câmara Municipal, que foi aprovada por maioria dos votos, apesar dos conselheiros Pedro Calmon, Miran Latif e Roquette Pinto “[...] votado no sentido do tombamento se restringir ao arco cruzeiro, altares e alguns outros elementos do interior da igreja, uma vez que o seu exterior se acha descaracterizado.” "99(ATA, 1953, p. 18). Assim como a igreja de Cachoeira do Sul, a matriz de Baependi já sofrera alterações em sua fachada, principalmente pelo acréscimo de duas torres sineiras.

Os casos acima citados nos levaram ao seguinte questionamento: quais critérios foram norteadores das decisões de tombamento nas reuniões do Conselho Consultivo ${ }^{70}$ ? O caso de Paranaguá não foi localizado nas atas das reuniões, sabemos que a segunda proposta foi enviada pela Prefeitura em 1951. Dentre as atas do Conselho, existem intervalos anuais sem nenhum tipo de registro, isto se observa nos anos de 1949-1953 e 1953-1955. Desta maneira, o tombamento voluntário das igrejas da Ordem e São Benedito não foram avaliados pelo Conselho, apenas pelos técnicos da instituição. Mesmo ainda conservando características "originais" de sua construção, estas igrejas, ao contrário, por exemplo, de Baependi, não eram consideradas de caráter nacional e apenas tinham

\footnotetext{
${ }^{69}$ Ata da $17^{\mathrm{a}}$ Reunião do Conselho Consultivo do Patrimônio Histórico e Artístico Nacional de 10 de fevereiro de 1953.

${ }^{70} \mathrm{O}$ Conselho Consultivo tem por função analisar os processos de tombamento compulsório, ou seja, nos casos em que o proprietário solicita impugnação à decisão do tombamento, e nos casos de tombamento voluntário, em que o pedido é originado pelo proprietário ou outro interessado. A legislação foi alterada em 1975 (Lei 6.292/75) exigindo que, para qualquer tipo de tombamento (mesmo quando o proprietário dê anuência após a notificação de tombamento), seja apresentado o parecer do Conselho Consultivo (RABELLO, 2009). A primeira reunião do conselho aconteceu em 10 de maio de 1938 e na Ata estão descritos os procedimentos para análise dos processos: os casos, já analisados pelos técnicos do IPHAN, são delegados aos conselheiros através de escolha do presidente, o relator deve fazer a análise da documentação até a próxima reunião para apresentar seu parecer e entrar em votação pelos outros membros, tendo aprovação ou não por maioria dos votos. Márcia Chuva (2009) analisou o Conselho entre os anos de 1938 a 1946, o grupo era formado por diferentes áreas do conhecimento, historiadores, arqueólogos, antropólogos, artistas, escritores e apenas um arquiteto, ao contrário dos quadros técnicos em que a grande maioria era da área de arquitetura.
} 
"importância local". Afinal o que mais pesava na decisão, as características externas, ou internas?

Outro caso descrito por Márcia Chuva (2009)é o da igreja de Santa Rita em Uberaba, seu tombamento foi solicitado por um morador da cidade e a autora afirma que havia empenho pelo IPHAN em considerar este tipo de pedido. A justificativa foi a falta de outros monumentos importantes na cidade e dessa maneira foi aprovado seu tombamento. A partir deste caso, podemos indagar se os processos de Paranaguá tivessem sido avaliados pelo Conselho Consultivo, as igrejas da Ordem e São Benedito já poderiam ter obtido registro nos anos de 1950. No caso parnanguara nenhuma igreja ainda fora tombada, o único monumento reconhecido era o Colégio dos Jesuítas. Mas também, por outro lado, apesar do caráter de autonomia que o Conselho deveria ter em relação às decisões dos técnicos do IPHAN, pois a decisão para o tombamento é da competência do Conselho, nas palavras de Maria Cecília Londres (2009) existia uma sintonia entre eles e mesmo em decisões discordantes, os pareceres eram atenuados de maneira a evitar maiores conflitos. Estas inconsistências dos fatos, as ausências da documentação, nos mostram que os critérios de análise aparentemente eram adotados de caso a caso. ${ }^{71}$

$\mathrm{O}$ interesse pelo reconhecimento federal das igrejas parnanguaras deve ter sido despertado pelo andamento das obras do Colégio Jesuíta, mesmo com os problemas que percorreram a primeira fase de restauração. Outro motivo são as comemorações do Tricentenário de Paranaguá, o prefeito Cominese, em carta dirigida à Câmara Municipal de Paranaguá, relatou publicamente a necessidade de investimentos na preservação do patrimônio histórico da cidade:

Como ressaltante dessa antiguidade Tri-Secular possue Paranaguá as suas acentuadas características coloniais que, além de lhe imprimirem cunho

\footnotetext{
${ }^{71}$ Quanto ao requisito da competência, no nível federal, a decisão do ato de tombamento cabe, precipuamente, ao órgão especificamente designado pelo Decreto-lei 25/37, ou seja, ao Conselho Consultivo do Patrimônio. Isso não quer significar que, no processo do tombamento, não haja a participação de outros órgãos ou agentes administrativos que informem o processo, praticando os atos preparatórios. (RABELLO, 2009, p.53)
} 
pitoresco, podem servir de atração ao tourismo e se converter em vantagem econômica para a cidade, com afluxo de visitantes.

Esse interessante cunho não contaria, no entanto, a natural tendência citadina para a moderna organização que pode ser feita sem a demolição bárbara e iconoclasta de prédios de feição antiga e de linhas puras do velho estilo colonial, hoje tão admiradas por amantes e estudiosos do passado brasileiro. (COMINESE, 1948 apud FURTADO, 2006, p. 402).

Pelo discurso do Prefeito de Paranaguá é possível perceber que a ideia de preservação ali contida estava alinhada com o que era preconizado pelo IPHAN neste período, o "velho estilo colonial" se torna elemento representativo da cidade, são ideias que foram efetivamente difundidas não apenas nas instâncias de atuação do Serviço do Patrimônio, mas também em outras instituições que não estavam diretamente ligadas com as atividades de proteção de monumentos.

Há também debates na Câmara Municipal sobre a restauração da matriz de Paranaguá, apresentando como justificativa sua representatividade para a história da cidade, dentre os quais vale a pena destacar um trecho do discurso do vereador Felipe Antunes:

Conceder auxilio para conservar um templo considerado monumento histórico, não é manter o culto da religião nele exercida. É concorrer para conservar de pé, como eloquente testemunho do nosso passado e do esforço creador dos nossos maiores, o edifício por eles erguido para, pela unidade da fé que os animava, trabalharam solidariamente no desenvolvimento do seu núcleo de população, gênese que foi da civilização paranaense. (LIVRO DE ATAS, 1951,pg 52-53)

Não devemos nos esquecer das iniciativas estaduais para a preservação do patrimônio, iniciadas nos anos de 1950. O Paraná já em 1953, talvez por ser o ano do centenário de fundação do Estado, implantou a Lei Estadual n ${ }^{\circ} 1211$, que criou dispositivos para a preservação do Patrimônio Histórico, Artístico e Natural do Estado do Paraná, incluindo normas gerais relativas à sua preservação. Através desta legislação, criou-se neste momento o instrumento jurídico que regulamenta a preservação de bens que podem ser tombados pelo Estado. Esta lei foi criada no 
governo de Bento Munhoz da Rocha ${ }^{72}$, filho do antigo prefeito de Paranaguá, Caetano Munhoz da Rocha.

A Lei Estadual 1211 é muito semelhante ao Decreto-Lei 25, cria os quatro livros do tombo e o registro obedeceu as seguintes características: vinculados a fatos memoráveis da história do Paraná e excepcional valor arqueológico ou etnográfico, bibliográfico ou artístico. Na década de 1950 houve o interesse pela identidade do Paraná que se buscava principalmente por seus monumentos, a gestão do Governador Bento Munhoz da Rocha, historiador, foi essencial neste contexto. Segundo Kersten (2000, p 135):

Bento era entusiasta dos trabalhos de Gilberto Freyre, atraído que fora pelos seus estudos sociológicos. Governou com o apoio de um grupo de intelectuais, retomando em certa medida o discurso paranista revestido por outra terminologia: paranidade. Em certa medida, este discurso foi recriado com base na concepção determinista e evolutiva da ideia de nação, aliada à visão católica e patriótica que norteava os institutos históricos e as discussões capitaneadas pelo Círculo de Estudos Bandeirantes, das quais o governador participava. (KERSTEN, 2000, p. 135)

Os anos 1950 são marcados pelo crescimento econômico e populacional do Estado, motivados principalmente pelas migrações ao norte paranaense atraídos pelo cultivo do café, Bento Munhoz “[...] definiu Curitiba como palco privilegiado para a instalação dos símbolos do progresso, da modernidade e da identidade da sociedade paranaense. Curitiba deveria ser o pólo cultural do Estado." (TRINDADE ET ANDREAZZA, 2001, p.109).

Apesar da precocidade da criação da lei estadual em 1953, os primeiros tombamentos estaduais só ocorreriam quase dez anos depois, em 1962, e os selecionados foram novamente, agora no âmbito estadual e com amplas possibilidades de sucesso, a igreja da Ordem Terceira e São Benedito. Assim, as primeiras obras de restauração de iniciativa estadual ocorreram logo em seguida, em

\footnotetext{
72 A gestão de Bento é considerada pela maioria dos intelectuais da época como produtora de ideias. Confere ao Paraná sua primeira identidade e insere-o no contexto nacional [...] (MAGALHÃES, 2001, p.56)
} 
1965, e foi de autoria do arquiteto Cyro Correa Lyra que era professor da Universidade Federal do Paraná. Ainda em 1965, houve uma nova solicitação ao IPHAN para o tombamento da igreja da Ordem e de São Benedito, através da iniciativa da Chefe da Divisão do Patrimônio Histórico e Artístico do Paraná, Dalena Guimarães Alves. ${ }^{73}$

Nesse período, já eram iniciadas as obras de restauração das duas igrejas com o auxilio técnico do IPHAN. É visível, pelas cartas encontradas nos arquivos, a insistência da Chefe da Divisão paranaense nas solicitações de auxílio técnico e não deixaremos de discutir esta questão em breve nos dois subcapítulos na sequência. A documentação foi enviada para a central carioca, que estava sendo dirigida temporariamente por Renato Soeiro. Em relatório de janeiro de 1966, ou seja, menos de um mês após a solicitação, o tombamento foi confirmado pelo arquiteto Paulo Thedim Barreto: "Considerando a igreja de São Benedito em relação ao seu meio opinamos pelo seu tombamento, inscrevendo-a no Livro do Tombo Histórico $^{74 . \prime}$ e a mesma justificativa foi apresentada para o caso da igreja da Ordem Terceira.

Mas na sequência, em outra carta enviada para o diretor, há uma alteração na justificativa do tombamento, Paulo Thedim Barreto tenta esclarecer a mudança de postura na decisão, pois foi ele que, em 1962, havia negado o registro:

Não mudamos propriamente de parecer, pois continuamos achar que a referida igreja tem o maior interesse local. Sucede apenas que após catorze anos julgamos que pelo seu vulto e interpretação dos seus elementos arquitetônicos a dita igreja é de valor excepcional para as partes meridionais do país, pelo que reafirmamos o nosso parecer favorável ao seu tombamento. (BARRETO, 1966)

Nos parece evidente que para o IPHAN, as igrejas parnanguaras, sendo edificações com características que não seguiam o padrão de outros exemplos

\footnotetext{
${ }^{73}$ Carta de Dalena Guimarães Alves ao diretor do Sphan Renato Soeiro, de 07 de dezembro de 1965. (Arquivo Central)

${ }^{74}$ Carta de Paulo Thedim Barreto ao Diretor da DPHAN, de 3 de janeiro de 1966. (Arquivo Central)
} 
excepcionais - eram diferentes das encontradas em Minas Gerais ${ }^{75}$ ou no Nordeste não atendiam, portanto, à mítica imagem do patrimônio brasileiro. $\mathrm{Na}$ primeira justificativa, muito sucinta, Barreto esclarece que sua importância se deve ao meio ao qual ela pertence. A importância dada às obras ditas "menores", não se restringindo apenas aos monumentos considerados mais relevantes é destacada na Carta de Veneza elaborada em 1964 e publicada em 1965, que estabeleceu, já no primeiro artigo, o seguinte:

Art $1^{\circ}$ A noção de monumento histórico compreende a criação arquitetônica isolada, bem como o sítio urbano ou rural que dá testemunho de uma civilização particular, de uma evolução significativa ou de um acontecimento histórico. Estende-se não só às grandes criações, mas também às obras modestas que tenham adquirido, com o tempo, uma significação cultural. (CARTA DE VENEZA, 2000, p. 92).

Entretanto, as discussões sobre a Carta de Veneza em solo brasileiro foram mais presentes a partir do curso de restauração e conservação empreendido pela FAU-USP em conjunto com o IPHAN e CONDEPHAAT em 1974 com a vinda de estudiosos estrangeiros e a participação de professores e técnicos das instituições. (KÜHL, 2010). Este contexto nos ajuda a compreender a razão do registro das igrejas feito apenas no livro Histórico ${ }^{76}$. Mas, vale esclarecer que, entre os técnicos, a Carta de Veneza já era discutida, notando-se uma visível dificuldade de Saia em aceitar as novidades: ele continuava apegado às diretrizes da Carta de Atenas. Isso fica bastante explícito na entrevista realizada com Augusto da Silva Telles ${ }^{77}$, responsável por introduzir o documento aos técnicos da DR. paulistana:

A Carta foi traduzida logo. E foi distribuída para os técnicos. E eu acho que houve umas duas ou três reuniões e conversas. Eu me lembro muito

\footnotetext{
${ }^{75}$ Esse patrimônio mineiro foi de tal forma reproduzido em revistas, jornais, mapas, folhetos etc. que, multiplicandose infinitamente, tornou-se ícone máximo de "brasilidade" na escala de valores que se impôs. O IPHAN esteve, sem dúvida, aderido ao projeto de nacionalização implementado pelo Estado Novo, ao unificar uma escala hierárquica de valores patrimoniais a partir de um padrão de arte e arquitetura determinado pela produção mineira colonial. As inúmeras frentes de ação integracionistas abertas pelo governo varguista redundaram em amplas medidas visando a nacionalização, tendo sido o Ministério da Educação e Saúde do mineiro Gustavo Capanema, uma das agências de ponta nesse projeto. (CHUVA, 2009, p. 63).

${ }^{76}$ As duas igrejas constam no mesmo processo, $\mathrm{n}^{\circ}$ 0455-T-51.

${ }^{77}$ Entrevista com Augusto da Silva Telles. In: Memórias do Patrimônio. Org. Analucia Thompson. Rio de Janeiro: IPHAN, 2010.
} 
bem de uma reunião que houve em São Paulo, em que eu fui incumbido de falar sobre a Carta de Veneza. Eu estava falando sobre a Carta, e o Saia ficou irritadíssimo, porque a Carta de Veneza tinha uma série de coisas que não havia na Carta de Atenas. Há uma diferença de conceitos, não só no sentido de contenção, como também no sentido de liberdade. Por exemplo, essa coisa da restauração não provocar obrigatoriamente uma unidade. A Carta de Veneza dá uma leitura muito mais rica e, portanto, mais perigosa: mais liberdade, mas ao mesmo tempo, mais exigências. (TELLES, 2010, p.120).

Analisando o contexto em que se deu o tombamento das duas igrejas, é interessante notar a rapidez na terceira tentativa e dois pontos importantes devem ser destacados: a forte iniciativa do governo paranaense na pessoa de Dalena Guimarães Alves, empenhada na tentativa de restaurar a igreja da Ordem e também a igreja de São Benedito, sendo que a primeira sofreu um incêndio, provocando uma grande mobilização do governo do Estado do Paraná para solicitar o auxílio dos técnicos do IPHAN na sua recuperação. Mas não devemos nos esquecer de que as três tentativas ocorreram num período de 14 anos desde seu início até o efetivo tombamento. Nas próximas discussões que tratam dos procedimentos para a realização das obras de restauro, poderemos observar com mais clareza as inconstâncias nas relações entre a DR. paulistana e a Central carioca, tornando evidente o desinteresse da DR paulistana, que detinha sob seu controle os estados do Sul. 


\subsection{IGREJA, MUSEU, SALA DE CONCERTOS OU TEATRO? A IGREJA DA ORDEM TERCEIRA DE SÃO FRANCISCO DAS CHAGAS}

A igreja da Ordem Terceira de São Francisco é mais um exemplo das relações estabelecidas entre as figuras-chave e das políticas de proteção do patrimônio pelo IPHAN no Paraná, mas diferentemente do Colégio Jesuíta, não há o envolvimento direto de José Loureiro Fernandes. Assim como na igreja de São Benedito, o Estado do Paraná, mais precisamente o Departamento de Cultura será o responsável por financiar e dar os primeiros passos para o tombamento e a restauração da igreja da Ordem. Todos os fatos que envolveram as duas igrejas, Ordem e São Benedito, aconteceram nos últimos anos da gestão de Rodrigo Melo Franco de Andrade frente ao IPHAN. O tombamento federal foi oficializado durante as obras de restauro, antes disso, os técnicos do Patrimônio já auxiliavam na restauração através de orientação nas atividades sob a tutela de Cyro Corrêa Lyra.

Para compreender as diversas intercorrências pelas quais passou a igreja da Ordem, propomos uma análise a partir das ações de proteção - do tombamento e da restauração efetuados pelos órgãos públicos, no âmbito municipal, estadual e federal e que tem por base, essencialmente, a documentação primária do $\operatorname{IPHAN}^{78}$, são cartas, pareceres, relatórios, fotografias e as entrevistas ${ }^{79}$ realizadas com os arquitetos Cyro Corrêa Lyra ${ }^{80}$ e José La Pastina.

Sabemos que o interesse na proteção da igreja da Ordem teve início com os levantamentos de David Carneiro, solicitados pelo IPHAN em 1937, na intenção de seu tombamento. Nessa época, segundo informações encontradas na Ficha de

\footnotetext{
${ }^{79}$ A entrevista ocorreu no mês de agosto de 2012 na cidade do Rio de Janeiro.

${ }^{80}$ Foi Diretor do Departamento de Cultura do Estado do Paraná e esteve responsável por obras de restauração em todo o Estado.
} 
Tombamento $^{81}$, a igreja estava abandonada e os acessos vedados com madeira. Um ano antes, consta em ata da Câmara de Paranaguá ${ }^{82}$, a denúncia de um dos vereadores sobre o abandono e a depredação da igreja, destruição de imagens e dos livros da irmandade.

O abandono desta igreja chegou ao limite em novembro de 1960, quando um incêndio iniciado na área próxima ao altar principal foi deflagrado, destruindo parte da cobertura, do altar e da sacristia. Pouco tempo depois a notícia foi reportada por José Loureiro Fernandes ${ }^{83}$, em carta contendo algumas fotografias do sinistro (Figura 30), ao Diretor Rodrigo Melo Franco. Segundo Loureiro:

Como já deve ter sido de seu conhecimento, vândalos tentaram, há um mês, incendiar essa antiga igreja de Paranaguá. O fogo foi posto na Sacristia, cujo interior foi totalmente destruído tendo o fogo se propagado à Capela Mór e à parte superior do altar-mor. Os bombeiros conseguiram dominar o fogo que destruiu esse sector do templo. ${ }^{84}$

Houve o silêncio do IPHAN sobre o caso, que só voltou a ser discutido em fevereiro de 1962, agora recorrendo à $4^{a}$ DR. Trata-se de uma carta do Diretor do Departamento de Cultura do Paraná, relatando ao Diretor do $4^{\circ}$ Distrito do IPHAN, o arquiteto Luís Saia, sobre o incêndio que "[...] destruiu parte do madeiramento da Sacristia, Capela e Altar-mor afirmando que $[. . .]^{85}$,o edifício já possuía o tombamento estadual ${ }^{86}$ e a Secretaria de Cultura necessitava de técnicos para a elaboração do projeto de restauração que teria o financiamento do Governo Estadual e da Prefeitura Municipal. Em anexo foi enviada uma análise do edifício, contendo descrição detalhada de sua situação após o sinistro:

\footnotetext{
${ }^{81}$ As Fichas de Tombamento foram enviadas por Rodrigo Melo Franco aos contatos estabelecidos pelo país com o propósito de inventariar edificações que eram cotadas para o tombamento. Para maiores informações ver o Capítulo 1.

82 Ata da sessão ordinária da Câmara Municipal de Paranaguá de 07/08/1936. (Acervo Câmara Municipal de Paranaguá).

${ }^{83}$ Loureiro nesse período visitava periodicamente Paranaguá devido as reformas do novo acesso para o museu proposto por Luís Saia.

${ }^{84}$ Carta de José Loureiro Fernandes a Rodrigo Melo Franco em 17 de dezembro de 1960. (Arquivo Central)

85 Carta do Diretor do Departamento de Cultura Ennio Marques Ferreira ao Diretor do $4^{\circ}$ Distrito do IPHAN, Luís Saia em 3 de fevereiro de 1962. (Arquivo IPHAN-SP)

86 As igrejas da Ordem Terceira e de São Benedito foram os primeiros edifícios tombados pelo Estado do Paraná após a criação do dispositivo de proteção do patrimônio paranaense em 1953.
} 


\section{PARANAGUÁ: IDENTIDADE E PRESERVAÇÃO}

O único existente é o retábulo do altar-mor. Os colaterais, aos quais se refere Vieira dos Santos ${ }^{87}$,desapareceram. Este retábulo pertence ao século XIX. Está muito atacado de cupim e apenas na sua extremidade superior foi atingido pelo incêndio. Foi avariado pela ruína da parte da cobertura da capela-mor; as peças que ruíram podem ser recuperadas. Atrás do retábulo há dois compartimentos - um térreo e outro superior. Esta parte posterior está muito atacada pelo cupim. Sôbre estes compartimentos se apóia o retábulo. O altar é recente e de feitio "goticista". 88

Figura 30: Imagens do incêndio da igreja da Ordem enviadas por José Loureiro Fernandes em novembro de 1960 , acima o acesso à sacristia e na imagem abaixo o altar. Fonte: Arquivo Central
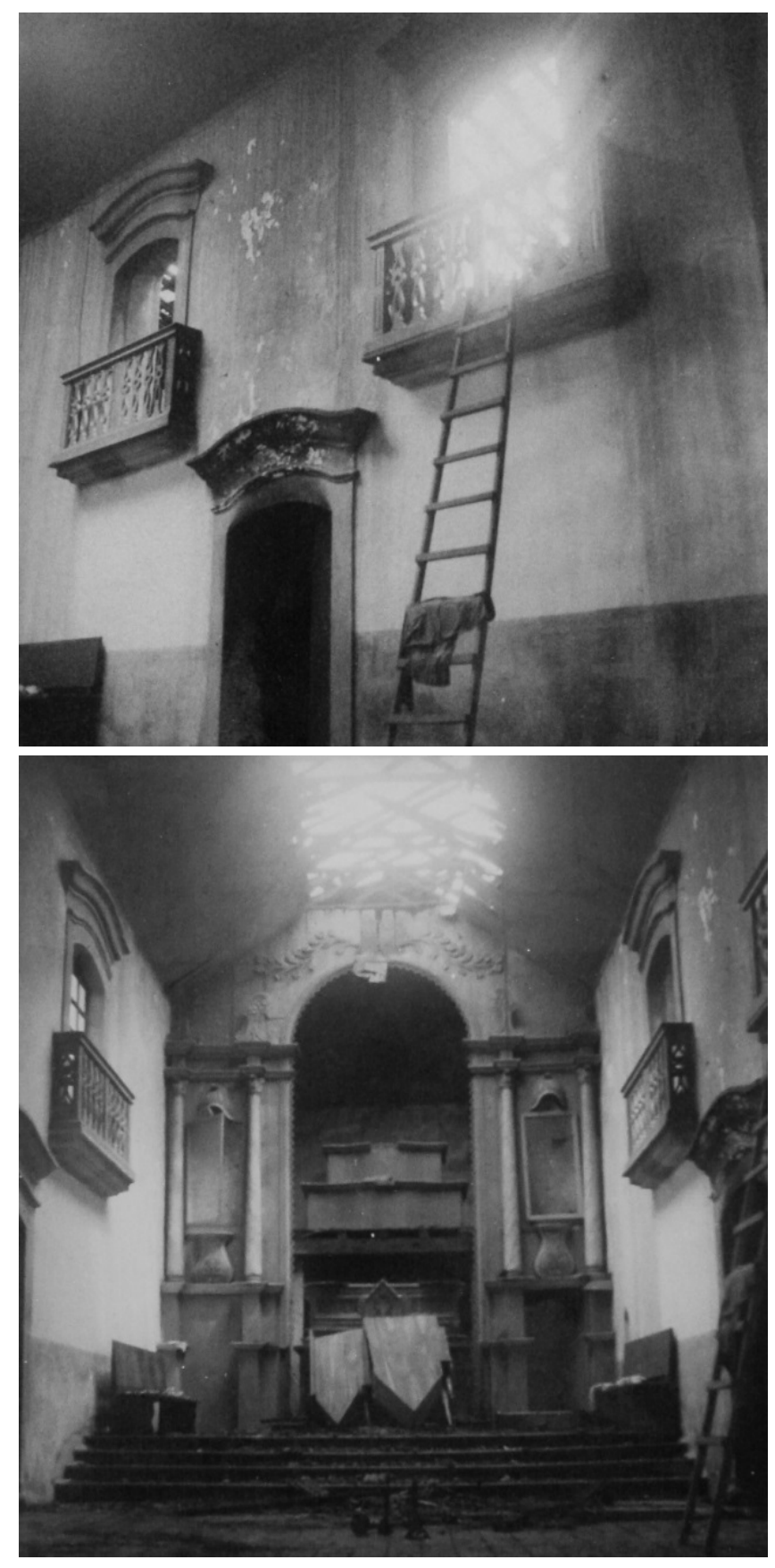

87 Vieira dos Santos (2001, p.129), descreveu o altar em 1850 da seguinte maneira: “Ornam a esta o altar-mor e dois colaterais; no principal está colocada no cimo da tribuna a imagem do Seráfico Padre S. Francisco das Chagas de vulto não pequeno, na postura de joelhos recebendo as cinco chagas de Jesus Cristo crucificado debaixo da denominação "O Senhor Jesus dos Navegantes", que lhe imprime as suas chagas."

88 Relatório anexado à carta enviada pelo Diretor Ennio Marques Ferreira ao Diretor do $4^{\circ}$ Distrito do IPHAN, Luís Saia em 3 de fevereiro de 1962. (Arquivo IPHAN-SP) 
A insistência dos representantes estaduais continua em carta de março do mesmo ano, quando Ennio Marques reiterou ao Diretor Luís Saia a solicitação de técnicos para a elaboração do projeto de recuperação da igreja. Não houve manifestação da Diretoria da $4^{\mathrm{a}}$ Regional, mas em agosto, consta em documento, a realização de levantamentos na igreja da Ordem com o intuito de avaliar os problemas decorrentes do incêndio e "[...] colher os dados necessários à sua avaliação como obra de arte no panorama da arquitetura barroca religiosa do sul do Brasil com o fim de tombá-la como patrimônio artístico." 89 .

Num pequeno trecho da carta de Ennio Marques a Rodrigo Melo Franco percebemos o descaso da $4^{\mathrm{a}} \mathrm{DR}$. em relação ao caso parnanguara:

Com o incêndio lavrado na igreja de São Francisco das Chagas, de Paranaguá, no ano passado, vemo-nos na contingência de promover sua pronta restauração. Como não contamos, no entanto, para esse empreendimento com o pessoal tecnicamente habilitado, recorremos, por sugestão de um dos membros do Conselho da Divisão do patrimônio deste DC, ao Dr. Luís Saia, do mencionado Distrito, em $3 / 2 / 62$, não tendo, até o presente, recebido resposta. ${ }^{90}$

Vale destacar que o Bispado da Ordem Redentorista de Paranaguá, não utilizava a igreja antes do incêndio, pois não lhes interessava mais tê-la como espaço de celebrações (LYRA, 2012). Mas sabe-se que a igreja estava há muitos anos abandonada, pois referências sobre o assunto são encontradas desde os anos de 1930.

Esta falta de respostas vai perdurar por mais alguns anos, é peculiar a atuação de Saia em relação ao caso das igrejas de Paranaguá, pois em nenhum momento encontramos cópias de suas respostas ao Estado do Paraná, muito provavelmente não ocorreram, uma vez que ficou clara a insistência da Chefe da Divisão do Patrimônio Histórico e Artístico do Paraná Dalena Alves em alguns

\footnotetext{
89 Documento intitulado: Levantamento feito em agosto de 1962 da igreja da São Francisco das Chagas de Paranaguá. (Arquivo IPHAN-SP)

${ }^{90}$ Carta de Ennio Marques a Rodrigo Melo Franco de Andrade em 24/03/1962. (Arquivo Central).
} 
telegramas enviados durante o ano de 1964, pedindo urgência em sua vinda, pois o departamento paranaense já havia obtido verbas para a restauração. ${ }^{91}$

É visível o desinteresse do IPHAN frente às igrejas, uma suposição é por não estarem classificadas no rol dos bens tombados nacionalmente e "[...] desprovida das características de valor excepcional [...]" como bem explicita Rodrigo na justificativa para a negativa ao tombamento ${ }^{92}$. Apesar disso, a instituição permitia a vinda de técnicos para orientar obras de restauração, mas não financiá-las.

Com a falta de respostas e o franco interesse dos responsáveis pela Secretaria do Estado da Cultura na restauração da igreja da Ordem, houve a informação sobre um professor do recém-criado curso de Arquitetura da Universidade Federal do Paraná, Cyro Corrêa Lyra, formado pela Universidade do Brasil e estagiário no IPHAN, durante sua estada em Curitiba esteve na Secretaria de Estado da Cultura onde conversou com Ennio Marques e este lhe solicitou realizar o levantamento da igreja da Ordem Terceira de São Francisco, o que foi aceito e feito em 1962.

É essencial o papel de Cyro frente ao patrimônio paranaense, pois é uma das figuras-chave que estabeleceu o contato entre as instâncias Estadual e Federal, entre Secretaria Estadual, $4^{a}$ DR e a Central do IPHAN, e será o primeiro profissional sediado no Paraná responsável por obras de restauração em Paranaguá, apesar de não ser funcionário do IPHAN.

A obra foi iniciada 1965, sem o auxílio direto do IPHAN, mesmo assim continuaram os pedidos de auxílio técnico à $4^{a}$ DR., novamente a Chefe Dalena Guimarães Alves insistiu para o Diretor Luís Saia “[...] conhecer o seu parecer sobre as restaurações durante nossa permanência nessa Divisão." ${ }^{93}$ Novamente não foram encontradas notícias da vinda de Saia à Paranaguá. Sabe-se que durante as obras de restauração, em 1967 o edifício em conjunto com a igreja de São Benedito

\footnotetext{
91 Telegramas enviados por Dalena Alves a Luis Saia em 23 e 26 de novembro de 1964. (Arquivo IPHAN-SP)

${ }_{92}$ Carta de Rodrigo Melo Franco a Dalena Guimarães Alves em 16 de novembro de 1962. (Arquivo Central)

93 Carta enviada pela Chefe da Divisão do Patrimônio Histórico e Artístico do Paraná, Dalena Guimarães Alves ao então Diretor do $4^{\circ}$ Distrito do IPHAN, Luís Saia em 17 de janeiro de 1966. (Arquivo IPHAN-SP)
} 
foi tombado pelo IPHAN, constando no livro do Tombo Histórico, muito provavelmente em decorrência da importância da atuação da Ordem Terceira em diversas partes do país, descartando possíveis qualidades artísticas desse monumento.

As obras de restauração que ocorreram na década de 1960 na igreja da Ordem foram simultâneas à igreja de São Benedito. Consistia no destelhamento da nave com a substituição das telhas francesas por telhas capa e canal, "semelhantes às primitivas" as telhas seriam obtidas de demolições na cidade, incluía o estudo para solução primitiva da estrutura da cobertura com o aproveitamento das tesouras que estavam em bom estado. Para o caso da cobertura, temos uma informação importante que se refere aos modelos de restauração como modus para a solução a ser aplicada. Augusto Silva Telles comunicou a Rodrigo Melo Franco do projeto da igreja da Ordem e do debate com Cyro sobre a solução dos forros chegando à conclusão de que deveria ser muito simples como aquela aplicada na igreja de Nossa Senhora do Pilar em Duque de Caxias. ${ }^{94}$ Modelo que também foi utilizado na igreja de São Benedito.

Em relação às fissuras nas alvenarias, utilizou a mesma solução empregada na igreja de São Benedito, com o uso do cimento, principalmente na fachada principal e no arco cruzeiro:

Para correção seguimos o seguinte método (já utilizado em S. Benedito): Após ampliar a rachadura, abrimos talhos transversais espaçados de 0.20 $\mathrm{m}$ onde engastamos ferros de 3/8" e 1/4". Finalmente injetamos argamassa de cimento, água e areia fechando todas as aberturas ${ }^{95}$.

Mas a restauração iniciada em 1965, não estava concluída em $1971^{96}$, tendo em vista que houve neste ano a solicitação da Câmara Municipal de Paranaguá ao

\footnotetext{
${ }^{94}$ Carta de Augusto da Silva Telles a Rodrigo Melo Franco em 8 de dezembro de 1965. (Arquivo Central).

951 $1^{\circ}$ Relatório da Obra de Restauração e Reforma da Ordem $3^{a}$ de São Francisco das Chagas em Paranaguá. Julho de 1966. (Arquivo Central).

96 Carta do Presidente da Câmara Municipal de Paranaguá ao Diretor Luís Saia de 16 de março de 1971. (Arquivo IPHAN-SP)
} 
$4^{\mathrm{o}}$ Distrito sobre os motivos que resultaram na paralisação das obras, alegando que existia risco de desabamento e perigo aos transeuntes. Em uma das últimas cartas desse período, ficou claro que a falta de verbas foi o motivo da paralisação: em maio de $1972^{97}$, a prefeitura parnanguara solicitou ao Diretor Luís Saia, auxílio para a finalização da obra, o que provavelmente não foi autorizado. A morosidade nas negociações marcou a primeira restauração da igreja da Ordem: foram mais de dez anos desde o incêndio até as primeiras intervenções. Há um relatório sobre a conclusão das obras de $1974^{98}$, sob responsabilidade do arquiteto Cyro Correa Lyra, que assumiu o cargo de Diretor do Patrimônio Histórico e Artístico do Paraná em 1973.

Dentre as ações executadas, constam no relatório a retirada do reboco da parede de fundo do altar e a reconstituição do telhado e das estruturas de madeira através da substituição de peças (Figura 31). O retábulo (Figura 32) não foi recuperado, pois não existem indícios nos documentos de sua restauração. Os danos causados pelo incêndio, seu desmonte e sua origem do século XIX podem ter oferecido os requisitos para que os técnicos não tenham cogitado a sua recuperação. No seu lugar veio, por sugestão de Cyro Correa Lyra em 1973 ${ }^{99}$, um dos retábulos laterais da antiga Matriz de Curitiba demolida no século XIX, que estava guardado no Museu Paranaense ${ }^{100}$ (Figura 33). Diante de tantas perdas, inclusive da imagem de São Francisco e outras ${ }^{101}$, ao trazer um retábulo com características barrocas, poderiam ser mais valorizadas as características originais do incendiado edifício? Em seu depoimento, Cyro afirma que essa proposta teve a intenção de recuperar seu uso religioso.

\footnotetext{
${ }^{97}$ Carta do Interventor Federal Gen. Div. João da Silva Rebello ao Diretor Luís Saia em 18 de maio de 1972. (Arquivo IPHAN-SP)

98 Relatório das Obras Feitas na Igreja de São Francisco das Chagas, Paranaguá, Paraná, de setembro de 1974. (Arquivo IPHAN-SP)

${ }^{99}$ Carta do Arquiteto Cyro Correia Lyra ao Diretor Luis Saia em 5 de julho de 1973. (Arquivo IPHAN-SP).

${ }^{100}$ De acordo com a carta de Cyro Lyra, o outro retábulo da antiga matriz ficou no Museu de Arte Sacra de Curitiba. 101 "No altar colateral ao lado do Evangelho está colocada a imagem de Nossa Senhora da Conceição e o do lado da epístola o da Nossa Senhora da Guia, e nos dois nichos do altar-mor Santa Teresa e Santa Rosa de Viterbo." (Vieira dos Santos, 2001, p.129)
} 
A igreja da Ordem, incendiada e abandonada, carregava poucas características do século XIX, removidas na restauração, o resultado final assim como na igreja de São Benedito foi de um espaço limpo e branco, com a cobertura em estrutura aparente, sem forros, e sem altares. Apenas o grande paredão em pedra marca o fundo do altar principal em que foi instalado o altar colateral da Matriz de Curitiba. Para este caso, o uso influenciou na tomada de decisões para a restauração? As imagens existentes nesta igreja foram destruídas, o que transparece nessa proposta é uma ideia de espaço museológico, aparentemente o altar transferido seria a peça principal deste museu.

O grande problema no caso das igrejas em Paranaguá foi a chegada de padres americanos no período pós-guerra da Ordem Redentorista que não tiveram nenhum interesse em recuperar ou usar os antigos templos, isso perdurou por décadas e mesmo após a restauração os padres não tinham interesse em retomar as atividades litúrgicas como relata José La Pastina:

Aliás, com relação às igrejas eu queria ressaltar o seguinte, exatamente a cada dez anos o Iphan era obrigado a fazer uma intervenção brutal nos telhados, então em 72 e 73 a igreja de São Francisco havia sido restaurada, havia sofrido um incêndio. Em 81, 82, 83 a gente teve que refazer o telhado, refazer o telhado todo porque não havia manutenção a igreja estava abandonada, eu fiquei nessas últimas obras lá, eu acabei ficando com a chave da igreja durante anos, dois, três anos, porque $\mathrm{o}$ bispado não queria. A gente terminou a restauração, eu e o Cyro fizemos um projeto de museu de arte sacra na sacristia e fomos tentar devolver a chave da igreja pro Bispo, mas ele era da Ordem Redentorista, uma ordem americana e falou: Não, aquilo lá não é igreja, ela foi dessacralizada e eu não vou ficar com aquilo não. E não ficou! ${ }^{102}$

102 Entrevista de José La Pastina realizada em Curitiba no dia 26 de março de 2013. 


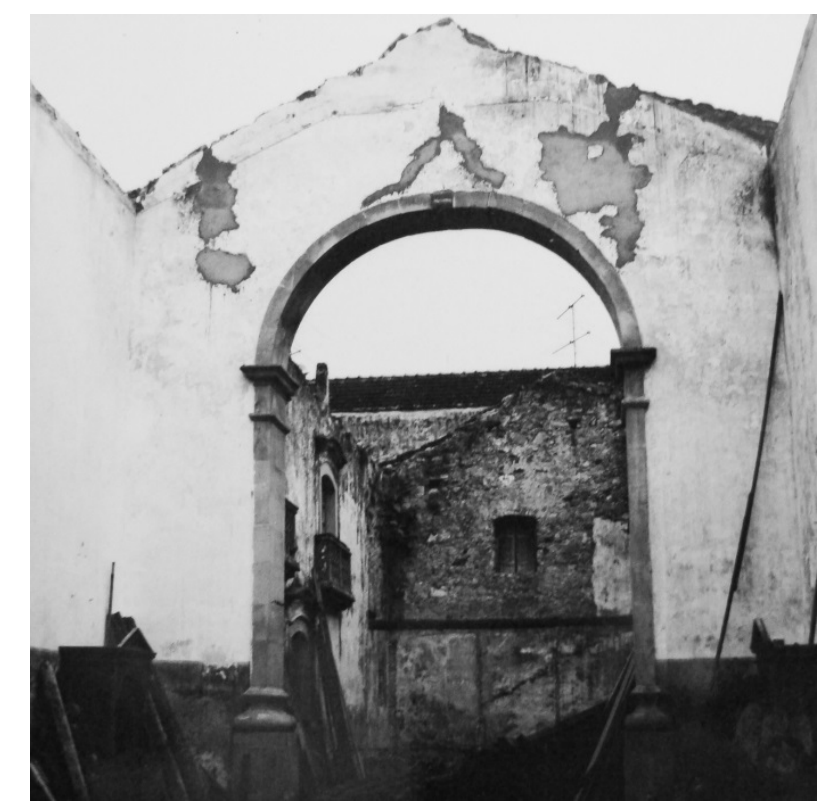

Figura 31: Imagens obtidas do relatório de Cyro Corrêa Lyra sobre a restauração da igreja da Ordem em 1966, observa-se o refazimento total da cobertura com estrutura em madeira, na imagem ao centro percebe-se o uso do concreto para a correção de fissuras acima do arco cruzeiro. Fonte: Arquivo Central
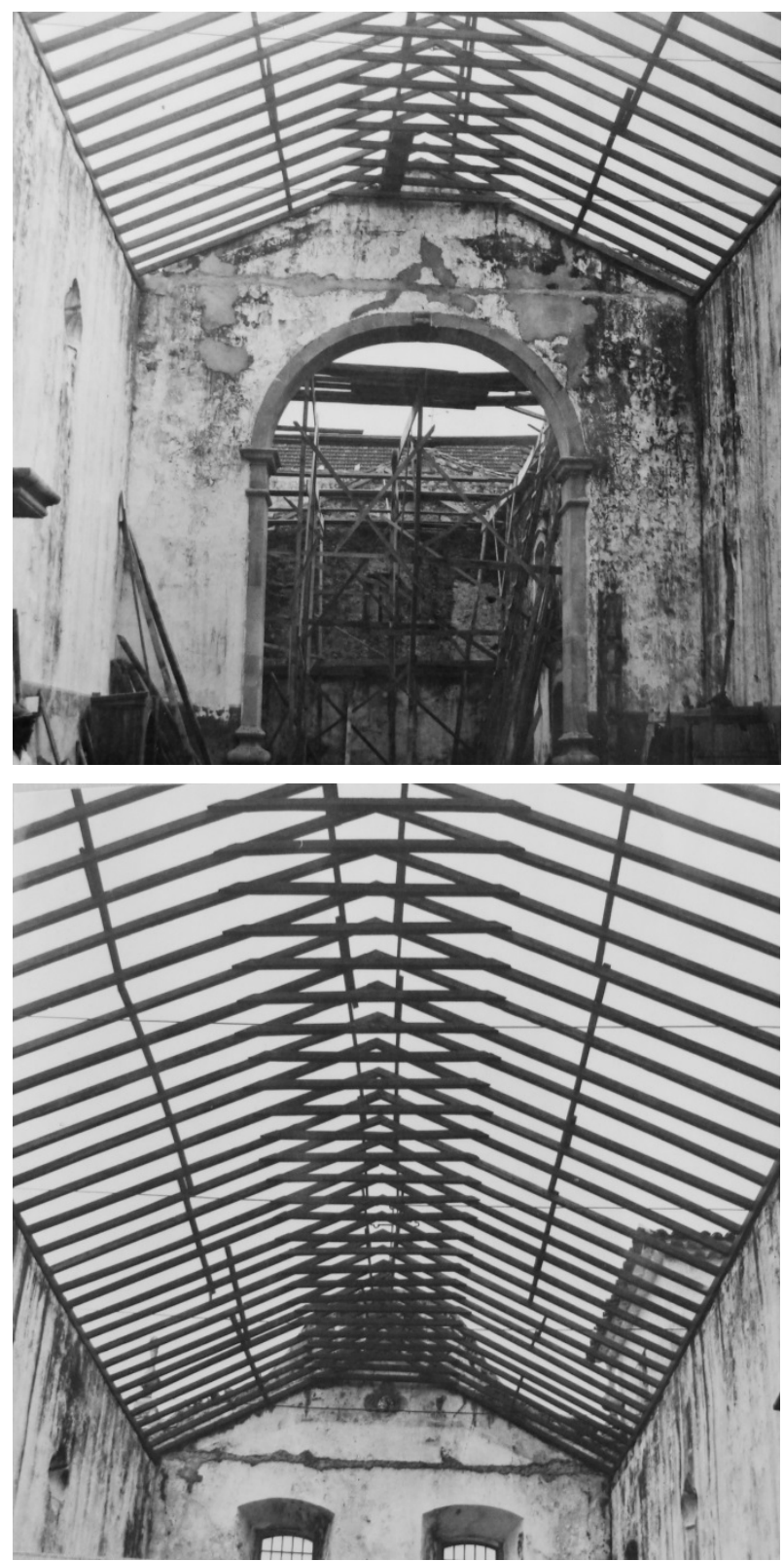

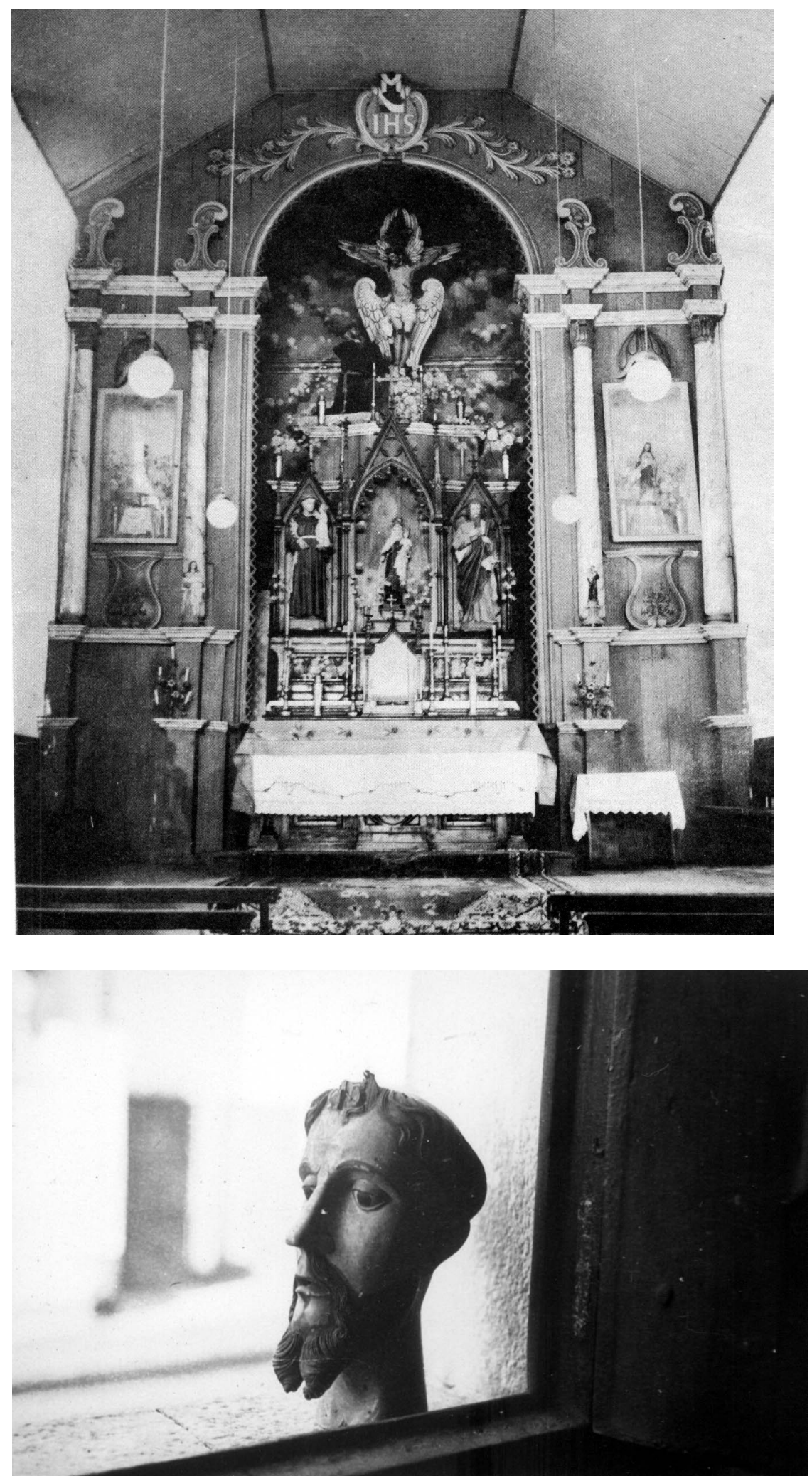

Figura 32: Acima, o altar da igreja da Ordem, antes do incêndio de 1960, abaixo a imagem de vestir de São Francisco em levantamento do IPHAN de 1941.

Fonte: Instituto Histórico e Geográfico de Paranaguá, Acervo Fotográfico do IPHAN-SP. 
PARANAGUÁ: IDENTIDADE E PRESERVAÇÃO

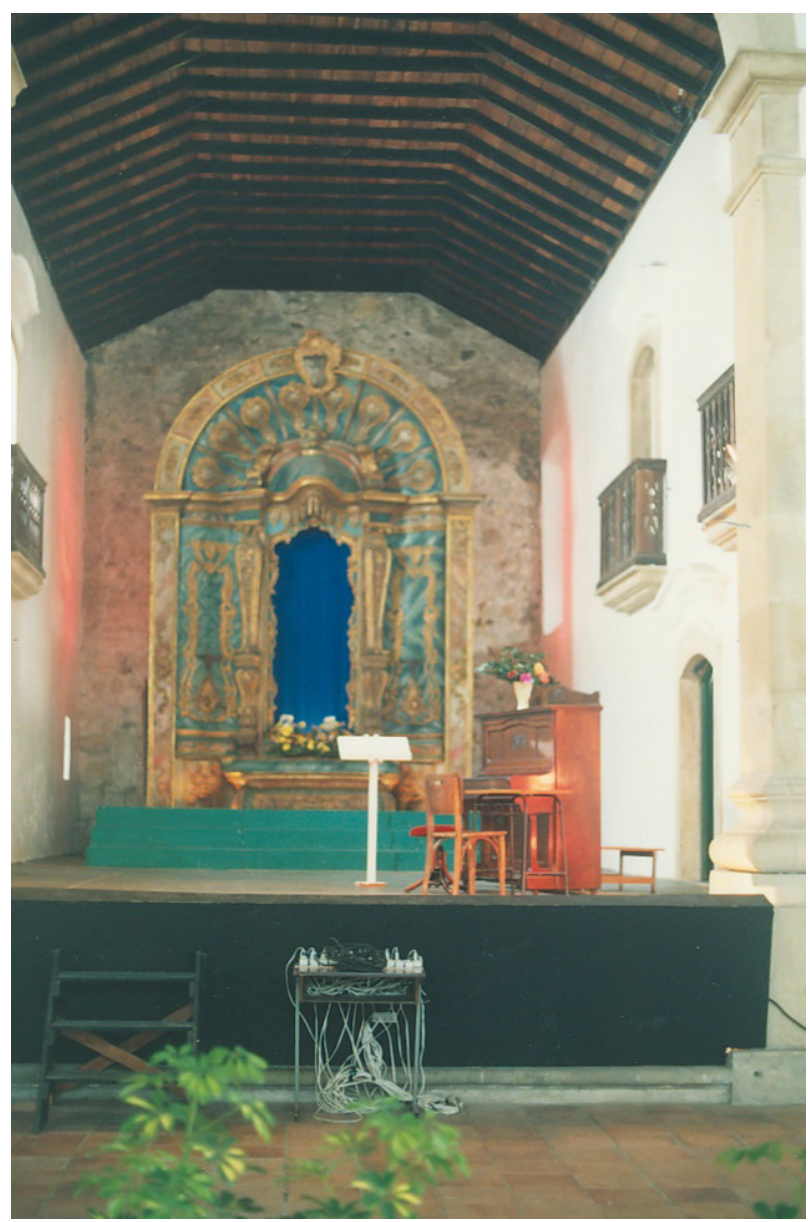

Figura 33: O retábulo colocado na igreja da Ordem Terceira na década de 1970.

Fonte: Arquivo fotográfico do IPHAN - PR; Arquivo Central do IPHAN - RJ

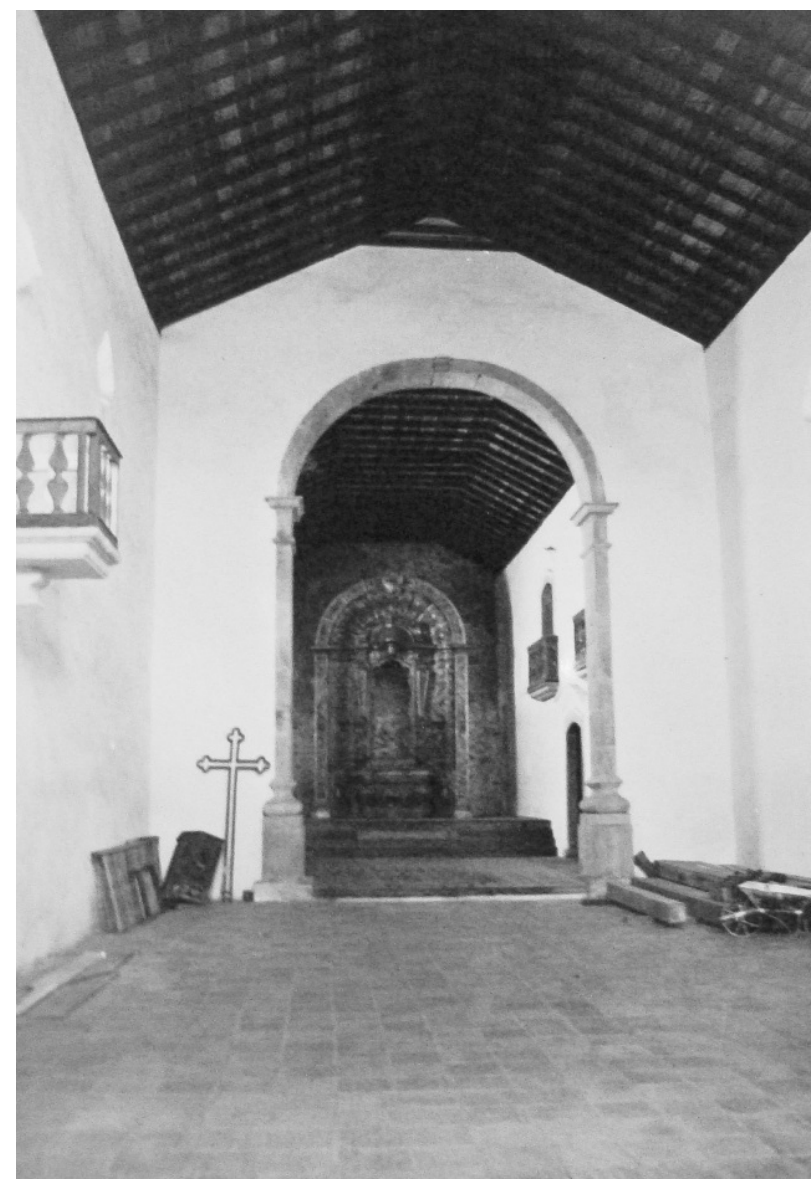


O que fazer com uma igreja em que não há interesse em mantê-la como espaço de culto? A dúvida suscitou para a segunda tentativa de recuperação da igreja da Ordem, em que ocorreu a reforma mais traumática capitaneada pelo agora Diretor do Patrimônio do Estado do Paraná Sérgio Todeschini Alves, durante a primeira gestão do prefeito José Vicente Elias, causando desentendimentos entre o IPHAN e a municipalidade. Segundo o arquiteto José La Pastina (2013), que presenciou todo o processo de restauro posterior as obras:

Aí o Todeschini Alves foi diretor do patrimônio estadual e fez o museu de arte contemporânea, então ele pintou de verde, de cimento e passou verniz por cima e resolveu fazer a mesma coisa na igreja de Paranaguá então quando a gente recebeu a notícia: o que é isso! Que absurdo. Então ele pintou a igreja de verde, de cor de cimento e passou verniz em cima, inclusive verniz em cima das cantarias então foi um absurdo né. ${ }^{103}$

A reforma foi conduzida de forma desastrosa. Em fotografias da época (Figura 34), percebemos o brilho resultante da impermeabilização das alvenarias através da aplicação do verniz, prejudicando o edifício, porque impediu a troca de umidade entre o ambiente externo e as alvenarias: acarretando em desprendimento do material, o que foi constatado por Saia Neto ${ }^{104}$, em 1982, após nova visita à igreja. Nas fotografias, percebemos o exagero na pintura à óleo que tornou as peças muito lisas e brilhantes (Figura 35).

Vale a pena nos determos nas propostas especificadas pelo corpo técnico do IPHAN neste relatório para corrigir a desastrosa intervenção executada pela Prefeitura. A primeira seria a raspagem das alvenarias para a retirada do verniz e da coloração verde clara, pois pela justificativa do técnico Saia Neto, “[...] tanto a cor utilizada para a pintura das alvenarias, como a solução de aplicação de verniz sobre a tinta nunca terem sido solução corrente em nenhuma época [...]". Ou seja, percebemos que a análise foi feita a partir de um pressuposto de caráter históricoestético e não de um caráter técnico: não demonstrou maior preocupação com

\footnotetext{
${ }^{103}$ Entrevista de José La Pastina realizada em Curitiba no dia 26 de março de 2013.

${ }^{104}$ Carta de José Saia Neto à direção da 9a Regional em 10 de agosto de 1982. (Arquivo IPHAN-SP)
} 


\section{PARANAGUÁ: IDENTIDADE E PRESERVAÇÃO}

possíveis danos à fixação do reboco na alvenaria que aquela intervenção poderia causar. Da mesma forma, a análise de Saia Neto não se detém em considerações a respeito da retirada do reboco interno da parede do altar, aparentemente confirmando pouca importância à manutenção da alvenaria original com argamassa para o contexto do edifício.

Figura 34: A única foto a cores encontrada deste restauro: notar o brilho das paredes resultantes da aplicação de verniz. Fonte: Acervo Fotográfico IPHAN-PR

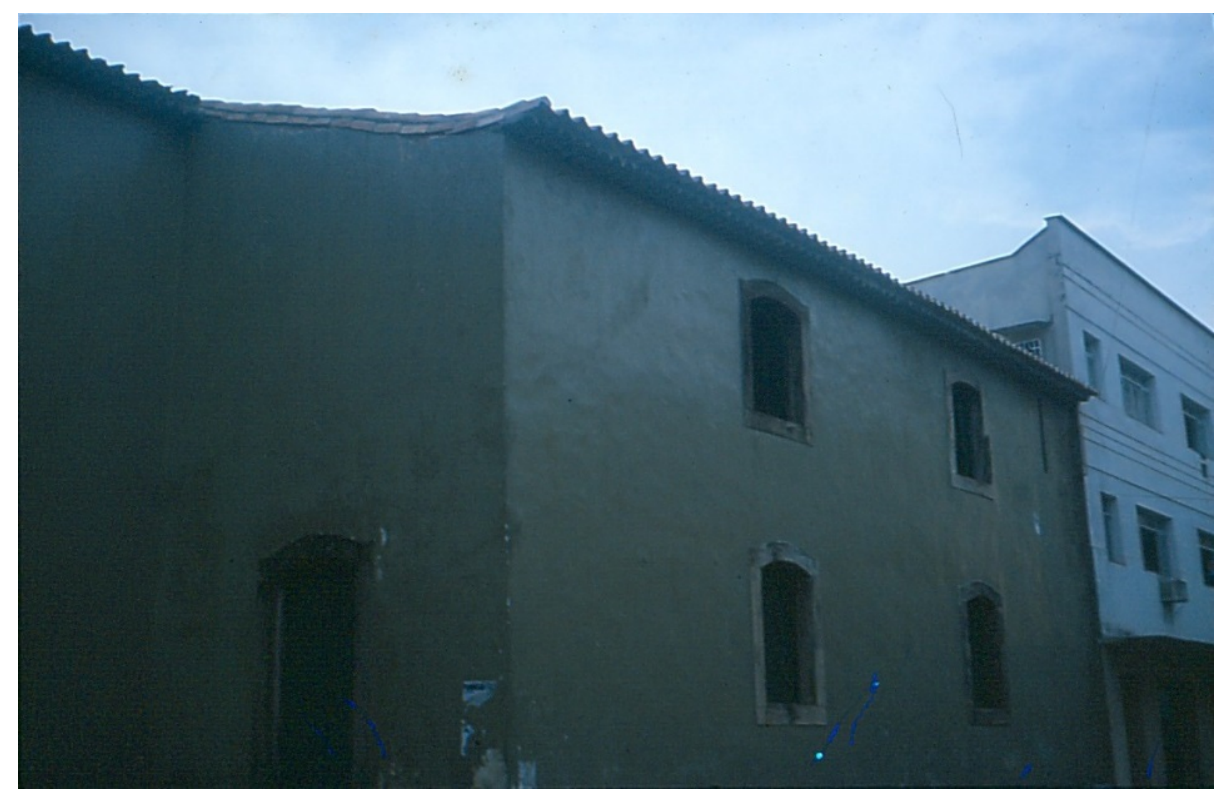

Figura 35: Reproduções de fotografias do levantamento de José Saia Neto em 1981: notar o detalhe da porta principal, com quadro manchado pelo Neutrol e madeira excessivamente brilhante; ver também o detalhe do cunhal manchado pelo mesmo produto.

Fonte: Arquivo IPHAN - SP.

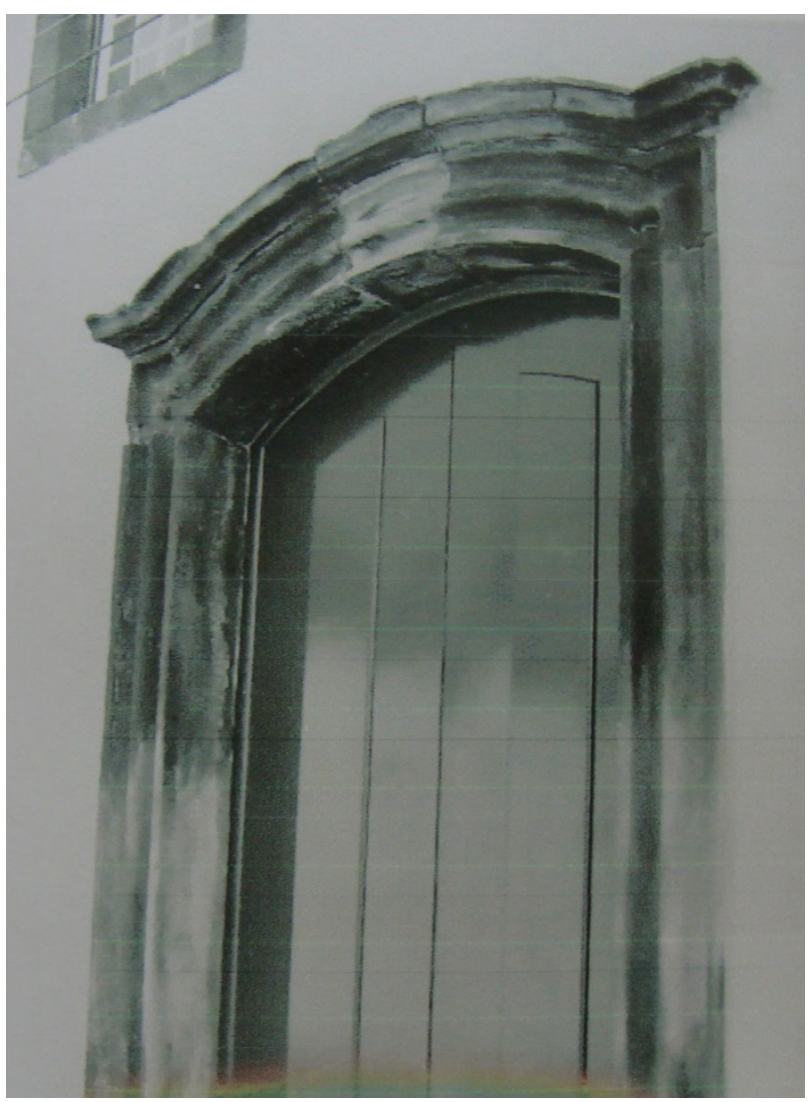


No caso dos elementos em cantaria, foi aplicado Neutrol ou Igol $2^{105}$.O grande problema desse tipo de produto é que, além de impermeabilizar, possui coloração escura e provoca manchas. Outra crítica de Saia Neto compete à forma de utilização do interior da igreja diante da função que exercia como espaço cultural $^{106}$. Ele aponta para a precariedade da iluminação, com lâmpadas presas no arremate do arco cruzeiro, na área expositiva criada na nave da igreja. Além disso, os quadros expostos e uma placa de bronze ${ }^{107}$ foram fixados diretamente nas paredes da igreja, itens igualmente criticados por Saia Neto em seu relatório.

Para resolver os problemas Saia Neto indicou no relatório o lixamento das paredes e a retirada integral do verniz e, posteriormente, a repintura na "cor original branca". Também solicitou a limpeza dos elementos em cantaria, o que demandaria uma análise técnica para definir o tipo de conduta na retirada do produto.

Em agosto de 1981, a Chefe da Curadoria do Patrimônio Histórico e Artístico do Paraná, Jussara Valentini, encaminhou ao IPHAN projeto de restauro da igreja da Ordem. Nesse projeto (PARANÁ, 1981), houve nova proposta de uso para a igreja da Ordem: agora como sala de concertos com a justificativa da inexistência de um ambiente desse tipo na cidade. A autoria do projeto é de Jussara Valentini e Rosina Parchen, baseando-se claramente no antigo projeto de Correa Lyra de 1965. Por esse projeto de restauro, dentre as principais atividades está a revisão do assoalho e do madeiramento; a troca do telhado, utilizando telhas novas na parte do canal e telhas antigas nas aparentes e a reconstrução do guarda-corpo do púlpito. Nas argamassas de revestimento, a proposta foi a retirada integral do reboco, a aplicação de um selador e a reaplicação de um novo emboço e reboco, composto por areia de rio e aplicação de silicone na parte interna da parede do altar que estava sem revestimento. O projeto foi aprovado pelo Programa de Cidades

\footnotetext{
105 Produtos com base asfáltica e que possuem a função de impermeabilização, largamente utilizados em baldrames e estruturas em concreto.

106 Provavelmente foi nessa reforma que a Prefeitura optou por criar um espaço cultural na igreja por sorte mantendo o retábulo curitibano.

${ }^{107}$ Comemorativa da reforma e da inauguração como espaço cultural colocada pela Prefeitura
} 
Históricas e pelo IPHAN em janeiro de $1982^{108}$, permitindo a partir daí o processo licitatório.

Em junho de 1984, foi apresentado o relatório final. Nele vale destacar a constatação do uso de tinta látex na pintura interna, tinta com conservado $\mathrm{P}^{109}$ nas paredes externas e aplicação de silicone no lado interno da parede dos fundos da capela-mor. No caso da limpeza das cantarias, que continham impermeabilizante com base asfáltica, o relatório coloca:

Este item causou uma série de problemas em função da inexperiência da empreiteira contratada. Recusamos a $1^{\text {a }}$ limpeza, executada com ácido muriático e escova de aço, e orientamos quanto à maneira correta de efetuar o serviço: diluição do produto asfáltico aplicado sobre a pedra com removedor e remoção com jato de água sob pressão. $\mathrm{Na}$ visita final, embora não totalmente satisfeitos, consideramos o trabalho aceitável. ${ }^{110}$

E quanto ao uso a ser dado ao monumento, ficou estabelecido em acordo entre o Programa de Cidades Históricas, a Divisão de Tombamento e Conservação do IPHAN e a Prefeitura Municipal, a proposta de uso cultural que transformou a igreja no Teatro da Ordem, com um contrato de dez anos, "[...] não podendo executar qualquer alteração no prédio ou modificar seu uso sem prévia e expressa autorização da SPHAN/SEC/Pró-Memória."”111

Desse modo, percebemos claramente na trajetória de conservação da igreja da Ordem, os conflitos e as dificuldades existentes entre a Prefeitura Municipal de Paranaguá, o Estado do Paraná e o IPHAN. É evidente a falta de técnicos para atender à demanda do distante município de Paranaguá e, no caso particular, a igreja da Ordem. Solicitações sucessivas caem no vazio sendo que após o primeiro restauro, o próprio governo municipal resolveu restaurar o monumento, causando tantos sérios problemas e agravando o mal estar entre as instâncias. Na década de

\footnotetext{
108 Ofício do coordenador do Programa de Cidades Históricas Henrique Oswaldo de Andrade ao representante da $9^{\mathrm{a}}$ Regional Antonio Luis Dias de Andrade em 14 de janeiro de 1982. (Arquivo IPHAN-SP).

109 Produto que tem a função de proteger estruturas.

110 Relatório final apresentado por José La Pastina em 25 de junho de 1984. (Arquivo IPHAN-SP).

111 Termo de Compromisso firmado entre a Fundação Nacional Pró-Memória e a Prefeitura Municipal de Paranaguá, em 5 de janeiro de 1984. (Arquivo IPHAN-SP).
} 
1980, houve uma melhora nos contatos entre o Estado do Paraná e o IPHAN, com a vinda de técnicos e a representação do órgão no Estado através do Escritório Técnico.

Quanto à tônica dos pareceres constantes dos relatórios, percebemos uma maior preocupação estética do que técnica, por vezes faltando uma análise mais equilibrada dos aspectos construtivos e históricos. Prevalece quase sempre o desejo da "originalidade". Vimos na documentação consultada, a elaboração de projetos em que notadamente havia o anseio de uma possível volta ao estado inicial, quase sempre imaginado, em clara consonância com o modelo pré-estabelecido pelo IPHAN com sua valorização da arquitetura do período Colonial ${ }^{112}$.

Esses tipos de conflitos e disputas ocorridos na conservação da igreja da Ordem, que constatamos através da documentação consultada, colocam também Paranaguá, apesar de não pertencer ao principal eixo de reconhecimento do patrimônio nacional, no bojo da mesma política preservacionista, sujeita à mesma conjuntura estrutural do IPHAN, uma questão que de certa forma se arrasta até os dias atuais na preservação do patrimônio cultural brasileiro.

\footnotetext{
${ }^{112}$ Ver Andrade, Antonio Luiz Dias de. Estado Completo que Pode Jamais ter Existido. 1992. Tese (Doutorado em Arquitetura e Urbanismo) - Faculdade de Arquitetura e Urbanismo - USP. Chuva, Márcia Regina Romeiro. Os Arquitetos da Memória: sociogênese das práticas de preservação do patrimônio cultural no Brasil (anos 1930-1940). Rio de Janeiro: Editora da UFRJ, 2009. Fonseca, Maria Cecília Londres. O Patrimônio em Processo: Trajetória da Política Federal de Preservação no Brasil. Rio de Janeiro: UFRJ: IPHAN, 1997.
} 


\section{IGREJA DE SÃO BENEDITO: LIMPEZA ESTILÍSTICA PRODUZINDO UMA UNIDADE HISTÓRICA}

São Benedito, assim como a Ordem são igrejas muito expressivas no contexto urbano de Paranaguá, pois foram magnetizadoras do crescimento da então vila meridional da Colônia portuguesa. As duas igrejas constituem hoje os poucos remanescentes oitocentistas da cidade. Sobre as igrejas Cyro Corrêa Lyra (2012) comenta:

Em 65 eu comecei a trabalhar para a igreja de São Benedito e aí você a pouco me fez uma pergunta sobre o uso ou não da igreja. Paranaguá tinha três igrejas antigas, tinha não, ela têm três igrejas antigas: a Matriz, a São Francisco e São Benedito. Nessa época os padres, era uma congregação de padres norte-americanos, eles só usavam a Matriz. A São Francisco, porque São Francisco estava sem telhado, tinha sofrido um incêndio e não tinha condições de usar como igreja, além de pertencer a uma irmandade, havia todo um problema de propriedade, de apropriação e a São Benedito eles não davam atenção é uma igrejinha pequenininha pertinho da Matriz. Eventualmente a irmandade de São Benedito conseguia que um padre fosse celebrar, ela era muito abandonada. É interessante isso porque na realidade você tem ali as duas irmandades, a irmandade rica e a irmandade pobre. A irmandade pobre é a irmandade de São Benedito, era uma irmandade de negros numa ponta da cidade e São Francisco era irmandade de ricos. Uma das coisas curiosas é que a São Benedito era a única que mantinha as suas imagens antigas, São Francisco era queimada e não tinha mais nada e a Matriz tinha sido toda alterada e também não tinha mais imagem nenhuma. Na realidade foram os pobres que preservaram, o que é muito comum é a regra, não tem aquela ganância de fazer dinheiro com as obras de arte.

Da mesma maneira que a igreja da Ordem (Ordem Terceira de São Francisco das Chagas), São Benedito foi restaurada pelo arquiteto Cyro Correia Lyra. Diferentemente da franciscana, a igreja de São Benedito não sofreu nenhum tipo de sinistro grave e ainda era mantida em uso pela irmandade, mas em comum, estava o desinteresse da congregação em sua conservação. São Benedito, apesar da fachada pouco alterada (Figura 36), sofreu modificações em seu espaço interno, 
assim como muitas igrejas no século XIX, com a aplicação de pintura em estêncil de tonalidade azul, a inserção de altares colaterais e novos forros (Figura 37).

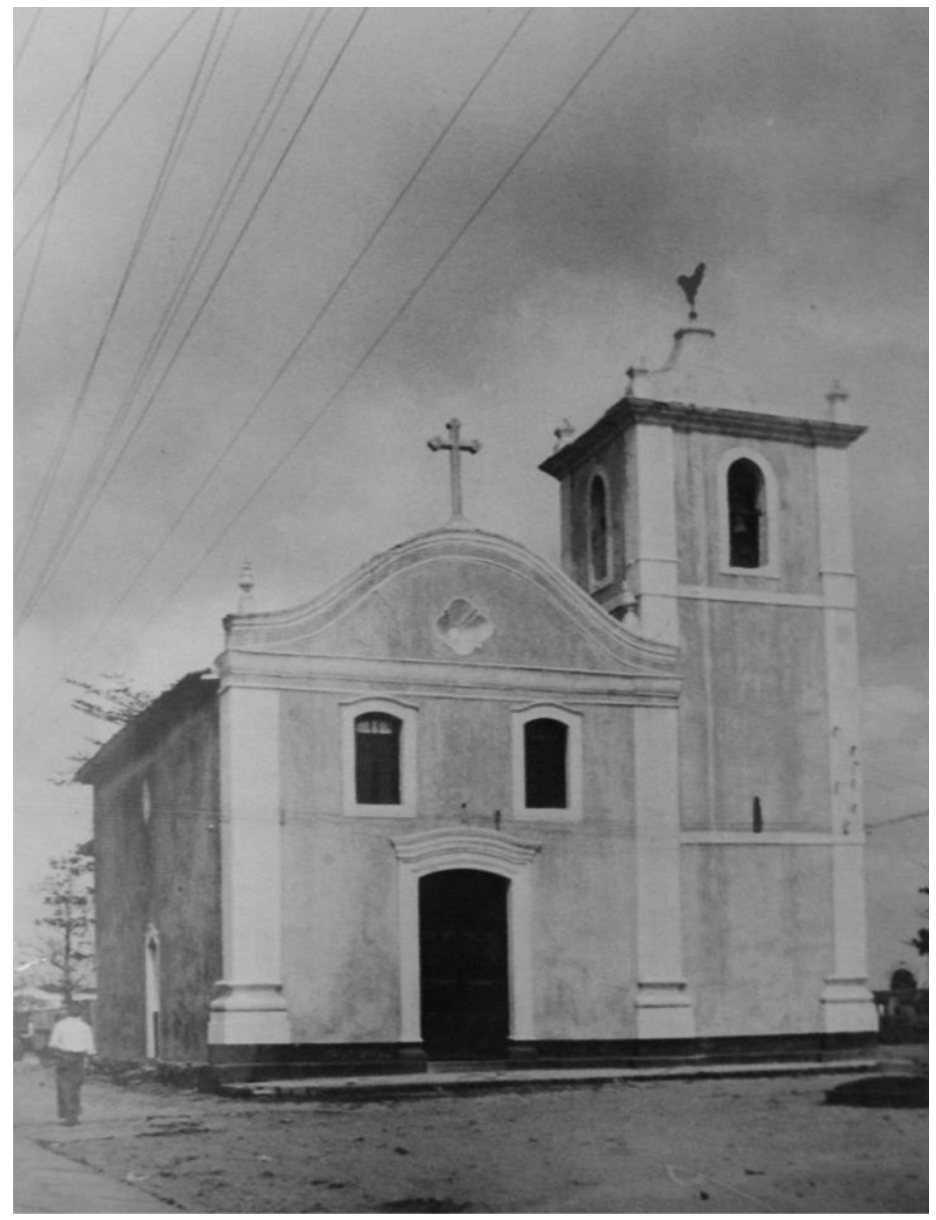

Figura 36: Fachada principal da igreja de São Benedito em 1940. Fonte: Hess, Erich, Arquivo Central do IPHAN

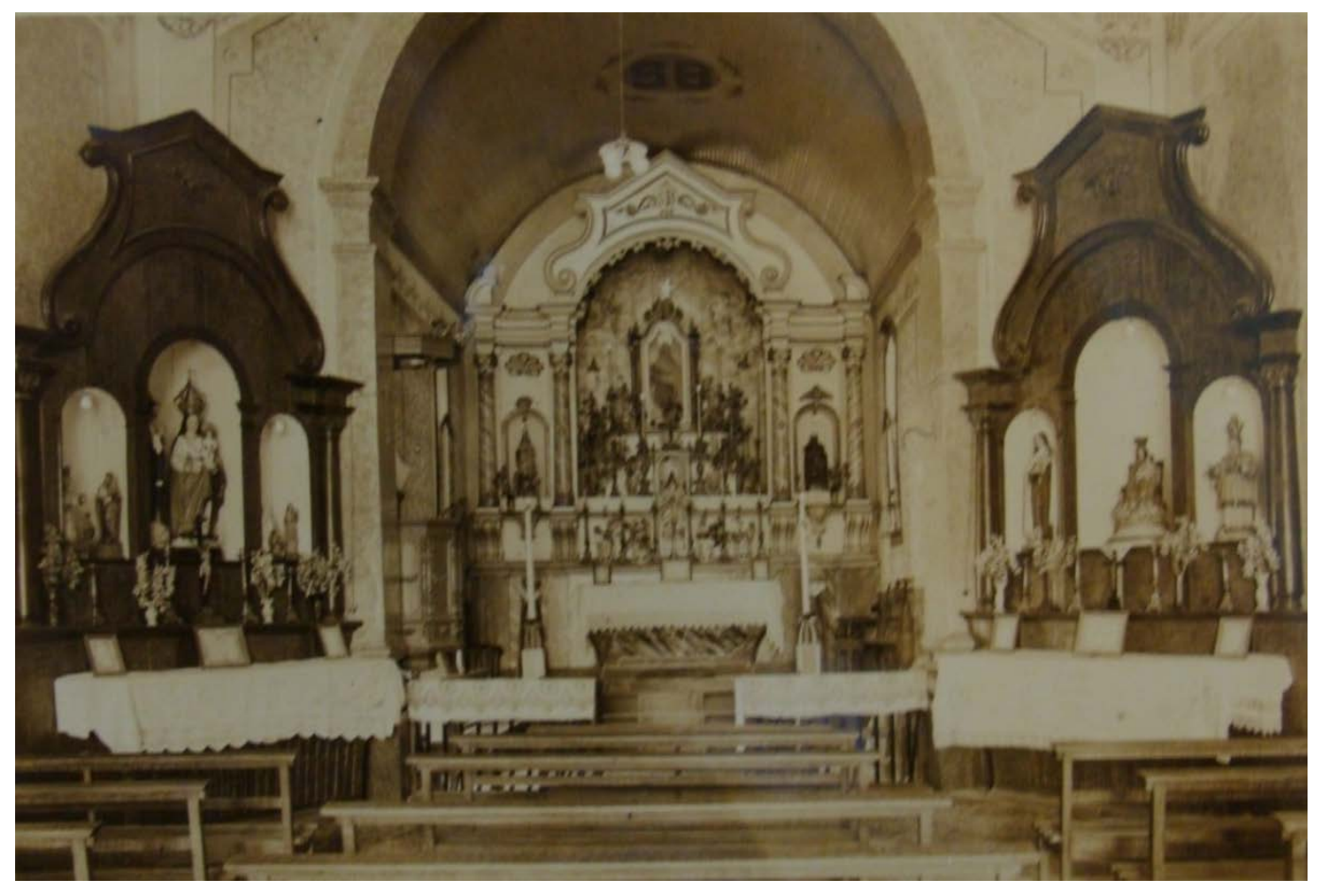

Figura 37:

Os altares

colaterais e o altar-mor da igreja de São

Benedito provavelmen te em 1940.

Fonte:

Arquivo

Central do IPHAN 
Os primeiros contatos de Cyro com Paranaguá aconteceram a partir de sua entrada na Universidade Federal do Paraná, em 1963, em Curitiba, no curso de Arquitetura e Urbanismo, lotado na disciplina Arquitetura do Brasil. Dentre as atividades didáticas, costumava levar os alunos à Paranaguá para visitas e levantamentos gráficos das igrejas (Figura 38). A iniciativa para a restauração parte de indicação do IPHAN, muito provavelmente após a emissão de correspondências por parte da Chefe da Divisão do Patrimônio Histórico, Artístico e Cultural do Paraná, Dalena Guimarães Alves:

E não me lembro mais se em 66 ou 67 por aí o patrimônio do Paraná me convidou para fazer o projeto de restauração da igreja de São Benedito. Porque eles tinham recurso para São Benedito teriam apoio do Porto de Paranaguá e eles pediram ao Sphan que desse um apoio e o Sphan me indicou. E eu me lembro porque houve uma certa hesitação por parte do pessoal do Paraná, porque eu era um arquiteto jovem e não tinha um currículo de projetos nessa área. Mas o Sphan me deu esse aval, disse: Não, confiamos que ele possa fazer esse trabalho e eu fiz com muito apoio do Sphan, esse projeto, acho que é 66 ou 67, isso é fácil a gente ver depois. (LYRA, 2012).

Figura 38: Uma das visitas dos alunos a Paranaguá, do lado esquerdo de paletó cinza está Cyro Corrêa Lyra, ao fundo a igreja de São Benedito, ainda amarela. Fonte: Acervo Cyro Corrêa Lyra

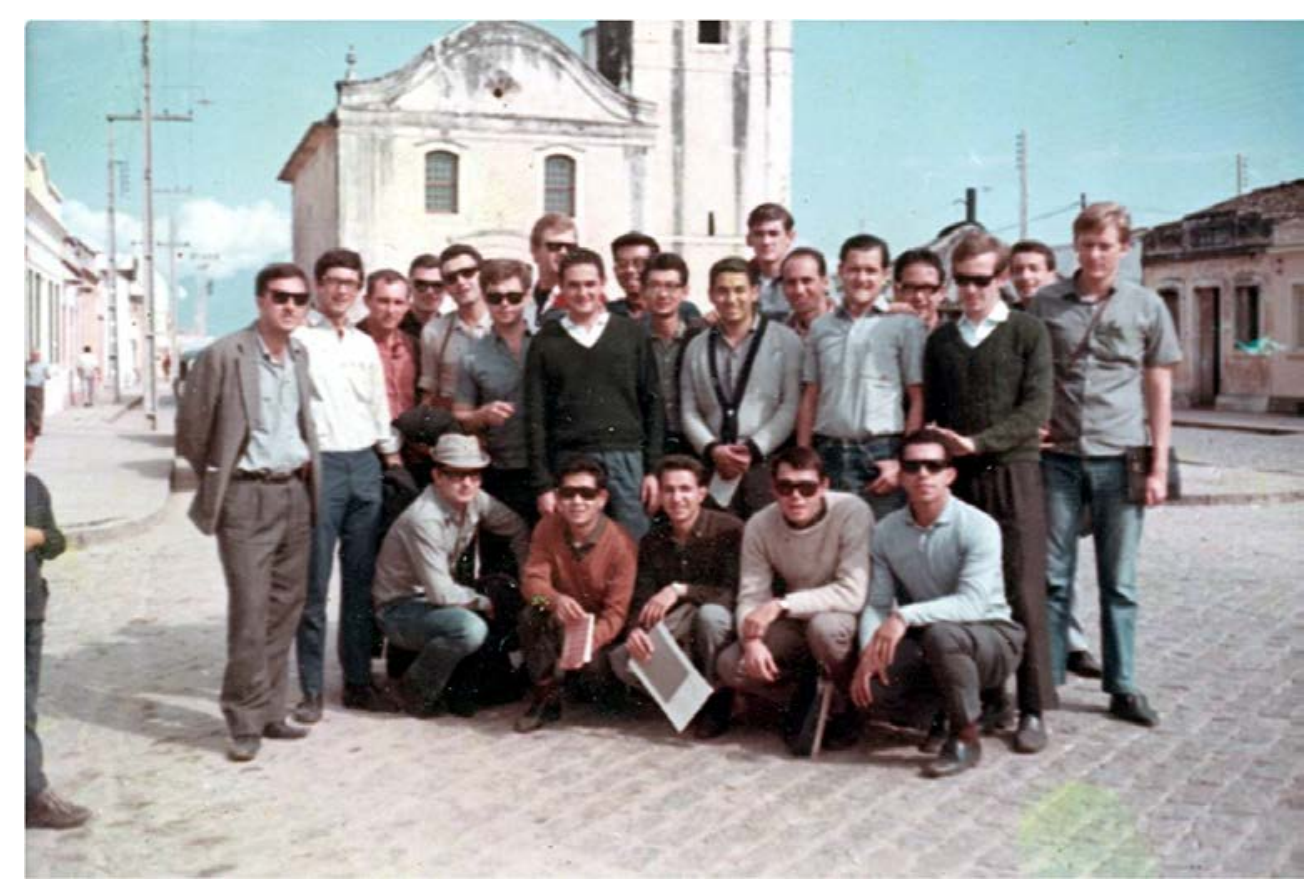




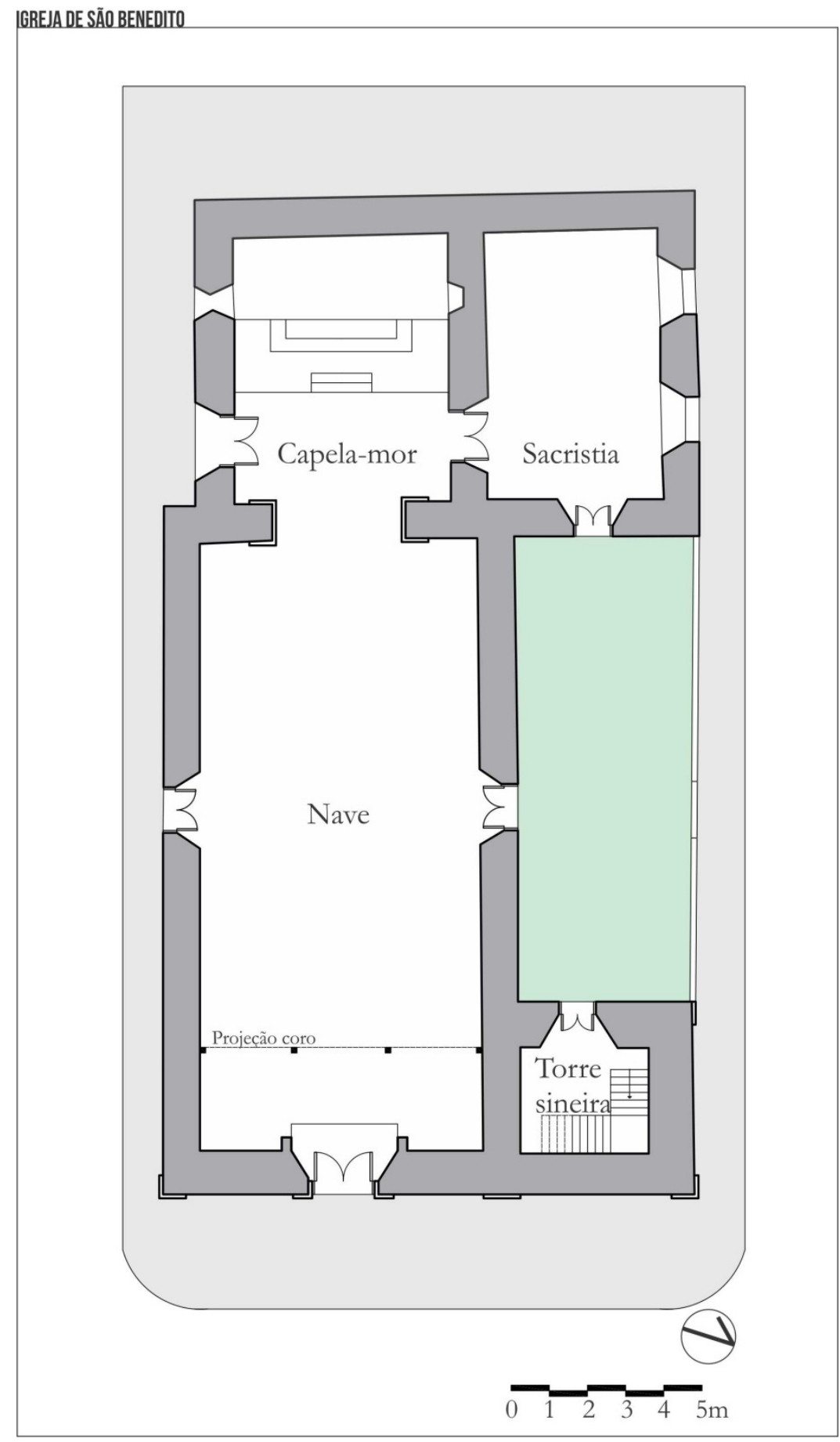

Figura 39: Planta da igreja de São Benedito após a primeira restauração. Fonte: Levantamento IPHAN-PR, Adaptado pelo autor 2015.

Apesar da hesitação inicial por parte dos paranaenses, Cyro possuía a indicação e o aval de um dos principais técnicos do IPHAN naquele período, o arquiteto Augusto Carlos da Silva Telles (a partir das redes de relações que estão sempre muito presentes nas atividades da instituição). O arquiteto Silva Telles teve grande atuação na instituição entre 1957 e 1988, tornando-se Diretor de Tombamento e Conservação (DET). Foi assistente de Paulo Santos e assumiu a 
disciplina Arquitetura do Brasil em 1969 na Universidade Federal do Rio, além da presidência da Fundação Nacional Pró-Memória. (THOMPSON, 2010). Teve ainda forte influência na carreira de Cyro Correia Lyra, como o próprio arquiteto afirma $^{113}$.

As cartas da chefe da Divisão Dalena Guimarães Alves, que se referem ao pedido de auxílio técnico para as obras de restauração, apenas citam a igreja da Ordem. Nos arquivos pesquisados não encontramos registros sobre o pedido de técnicos para a restauração da igreja de São Benedito. O contexto em que se iniciaram os diálogos entre as instâncias foi motivado pela urgência no caso da igreja franciscana, pois foi incendiada e por muito tempo ficou abandonada, houve também neste caso a interferência do professor José Loureiro Fernandes, comunicando Rodrigo Melo Franco sobre o sinistro. Apesar da urgência, as obras de restauro foram iniciadas conjuntamente, tanto na igreja da Ordem como em São Benedito ${ }^{114}$. É preciso destacar que a restauração foi iniciativa estadual e que o envolvimento do IPHAN nesta obra foi apenas de consultoria e orientação dos trabalhos. Cyro não era funcionário da instituição, mas sim professor da Universidade Federal do Paraná.

A análise e a discussão aqui apresentada partirá do estado em que se encontrava a igreja de São Benedito antes da restauração, iniciado com o levantamento gráfico da igreja, em março de 1965, como consta em fotografias localizadas no Arquivo Central do IPHAN e dos relatórios existentes no arquivo do IPHAN Paraná. Poderemos ter uma ideia do estado do monumento pelo relatório de 25 de maio daquele ano ${ }^{115}$. Sérios problemas foram identificados nas alvenarias de pedra, são rachaduras ao longo do edifício, uma delas na fachada

\footnotetext{
${ }^{113}[. .$.$] eu era orientado por Augusto da Silva Telles, que foi sempre o meu..., a pessoa através da qual eu entrei no$ Iphan, o Saia foi o segundo grande professor que eu tive porque eu viajei muito com o Saia. (LYRA, 2012).

${ }^{114}$ Há um conjunto de fatores que permitiu corroborar para a restauração dos dois monumentos, primeiramente o interesse do Estado na restauração, já que não eram edifícios tombados pela instituição federal, outro aspecto é a persistência do Diretor da Secretaria de Educação e Cultura, Ennio Marques Ferreira, e da Chefe da Divisão do Patrimônio Paranaense, Dalena Guimarães Alves.

115Relatório da Obra de Reforma e restauração da igreja de S. Benedito em Paranaguá. (Maio de 1965). (Arquivo IPHAN-PR)
} 
principal, partindo do frontão até a janela do coro (Figura 40 e Figura 41). Outro problema constatado é que as alvenarias estavam cedendo. A solução: uso do concreto armado. A proposta foi a construção de uma cinta em concreto no topo das paredes, substituindo peças em madeira que exerciam a mesma função; para as rachaduras, rasgaram-se as fissuras, com a retirada da argamassa, depois abertos talhos transversais às rachaduras, engastados grampos de ferro e injeção de argamassa composta de cimento, água e areia (quando sabidamente este componente, o cimento, não fazia parte da composição original). Método também aplicado ao arco cruzeiro. Sabe-se que as estruturas em pedra eram argamassadas com uma mistura de cal de conchas e areia, esta cal era obtida dos sambaquis, muito comuns na região.

A técnica se diferencia daquilo que Saia aplicou nas construções bandeiristas de São Paulo, em que o concreto armado foi embutido nas alvenarias, numa malha estrutural, como por exemplo, no Sítio Mirim. No caso de Paranaguá, o concreto foi acrescentado no topo das paredes e, na suposição de Cyro ${ }^{116}$, substituíam peças de madeira que exerciam a mesma função, solução também adotada em outros Estados, por exemplo, a Sé de Olinda. Nas duas situações, as inserções foram posteriormente ocultadas pelos revestimentos, e desta maneira tornando-se dificultosa sua identificação. O concreto armado não era apenas utilizado por razões técnicas, mas também por seu difundido emprego na arquitetura moderna. De acordo com Mayumi (2008, p. 70) ${ }^{117}$

A atualidade e a distinguibilidade do concreto armado eram também usadas como justificativas para seu emprego. Não só por razões técnicas, mas também ideológicas, o uso do concreto tornou-se uma solução aceita em todas as restaurações do IPHAN. Afinal, a experimentação com o concreto era sem dúvida uma maneira "moderna" de intervir nos

\footnotetext{
${ }^{116}$ Cabe uma ressalva no que tange a esta informação: a proposta de construção de uma cinta em concreto no topo das paredes, inicialmente não previa substituir as peças de madeira, estas peças foram encontradas posteriormente, durante a execução das obras, com esta descoberta Cyro supõe que as peças em madeira exerciam a mesma função das novas em concreto, por fim ele apresentou a ideia de substituição como uma das justificativas para o uso do concreto. Por isso entendemos como um procedimento de substituição e não de adição nesta leitura da justificativa do arquiteto.

${ }^{117}$ Lia Mayumi(2008), afirma que a substituição de madeiramento por estruturas de concreto não foi adotada em São Paulo.
} 
monumentos. Explorar os recursos do concreto armado nas restaurações era, naquelas circunstâncias, uma opção inexorável.

Devemos compreender que o material mais recomendado naquele contexto era o concreto, que possuía predicados irrefutáveis - "durabilidade" e "plasticidade" - para seu uso nas construções em qualquer circunstância - ainda que fosse numa obra de restauro - e, talvez, por ser uma técnica amplamente aceita naquele momento. Comparando a aplicação do concreto armado entre as duas obras Sítio Mirim e igreja São Benedito, poderíamos dizer que a proposta de Cyro Corrêa Lyra parece menos agressiva do que aquela de Luís Saia, isto porque não foi inserida na estrutura já existente, não houve o desbastamento de alvenarias (salvo nas rachaduras) e nem a retirada total das argamassas de revestimento.

Nas fotografias da obra de São Benedito, percebemos que as vigas de concreto foram produzidas diretamente sob a alvenaria de pedra (não foram préfabricadas). Este procedimento prejudicou ainda mais o estado de conservação das pinturas que existiam nas paredes internas da igreja. Entretanto, na proposta de Cyro, estas pinturas não tinham valor e foram totalmente cobertas pela nova pintura à base de cal (Figura 42).

Figura 40: Uma das fotografias do levantamento da igreja de São Benedito, notar a grande fissura no frontão próximo da janela direita.

Fonte: Arquivo Central

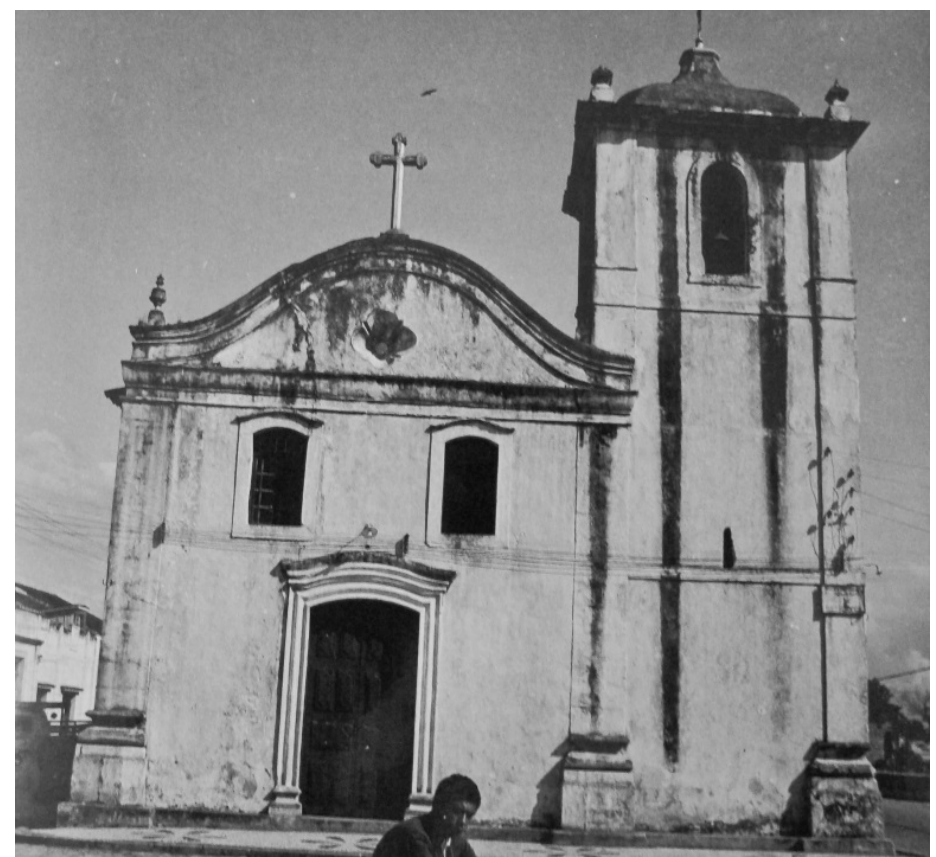


Figura 42: A igreja descoberta e a construção da cinta em concreto no topo das paredes desprotegidas. Fonte: Acervo IPHAN-PR.

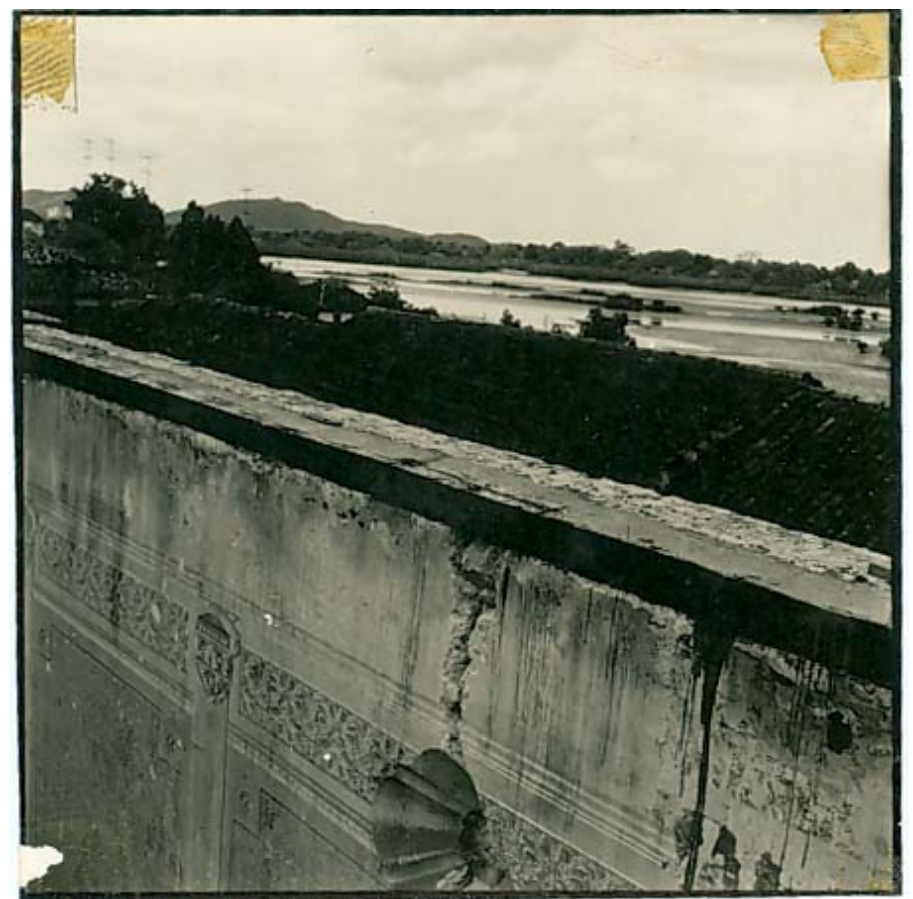

Outro ponto refere-se à solução dada à cobertura e às discussões pertinentes. No levantamento elaborado pelo arquiteto da igreja de São Benedito foi constatado que possuía cobertura em telha francesa, resultante de reformas anteriores, internamente havia na nave central um forro considerado recente, assim como no altar-mor, a pintura das iniciais do santo protetor "SB". É interessante acompanhar o desenrolar das discussões entre os técnicos que culminaram com a definição dos procedimentos de intervenção, principalmente na troca de cartas e na apresentação dos relatórios com as propostas de restauração, são documentos preciosos que apontam as posturas frente à obra. Através dos relatórios analisados no caso da igreja de São Benedito, a primeira atividade que antecede as obras de restauração é o levantamento gráfico e fotográfico (avaliação do estado atual). A partir das informações obtidas neste levantamento, são estabelecidos os critérios a serem adotados na restauração, ou seja, o que e como intervir. Os critérios são condicionados a partir da observação de registros físicos no edifício que permitam definir soluções que supostamente foram adotadas originalmente, são indícios na estrutura, ou vãos que foram fechados, etc. Portanto primeiro parte-se das análises sobre as soluções ditas "originais" que são interpretadas a partir dos registros 
físicos encontrados nos monumentos, para posteriormente estabelecer soluções a serem adotadas, de modo que podem ser anulados os registros posteriores, considerados prejudiciais à imagem pela qual se deve manter ou transformar. A partir de uma discussão sobre as possíveis soluções originais, serão dados os parâmetros para anular outras fases do edifício. Portanto dentro de um processo de projeto de restauro o método parte de uma análise com o propósito de restabelecer a tão almejada "imagem original".

Vejamos o caso a seguir, pelas discussões empreendidas para a proposta de restauro da cobertura, Cyro verificou que o forro da nave central cortava o óculo da fachada ao meio: sua hipótese é que a estrutura do telhado cedeu em 10 centímetros, afetando o óculo central. $\mathrm{Na}$ retirada do forro que ainda escondia a estrutura, constatou que a linha da tesoura encostada ao frontão estava mais baixa, levando-o a adotar a ideia de retirar todo o forro, mantendo a estrutura de cobertura aparente, sem nenhuma proteção. Ainda havia outro indício que permitiu ao arquiteto chegar a esta conclusão:

Diante da ausência de sinais indicativos de um forro primitivo, a solução primeira aventada foi deixar a nave em telha vã (provavelmente não existia forro, o que se pode concluir observando a pintura a cal da parede que se prolonga acima da linha indo ate a cumeeira).

Conforme verificamos, porém, tal solução não seria aceita facilmente pela Irmandade, já que a nave da igreja estava até agora "devidamente" forrada. Decidimos, então, lançar mão de medida já adotada em casos semelhantes no Estado do Rio, pelo DPHAN, conforme tivemos oportunidade de ver: forro tabuado sobre a armação, entre $O$ caibramento e as telhas. Essa solução tem a vantagem de forrar a nave sem esconder a armação. (LYRA, 1965, p.1)

De qualquer forma, para implementar a solução apresentada era necessário resolver o problema da antiga estrutura. Cyro lançou três hipóteses que foram enviadas à central do Rio e analisadas por Augusto da Silva Telles - a primeira, mais radical, apontava como solução o reposicionamento do telhado, a retirada de todo madeiramento e o completo refazimento com peças novas. A segunda opção 
é a manutenção do madeiramento em bom estado e a instalação de uma nova armação "idêntica" com a colocação do forro acima dos caibros e dessa maneira seria reconstituída a correção da altura. A terceira opção é a manutenção do madeiramento com a colocação de novas armações, mais altas, mas mantendo a armação antiga, intercalada com a nova e o forro seria pregado na nova armação.

A segunda solução foi preterida tanto por Cyro como pelos técnicos da central carioca, pois: "Não haveria o menor cabimento de, por motivos de querer voltar, exatamente, à forma primitiva, perder-se completamente o madeiramento original." (LYRA, 1965, pg. 3). Desse modo, percebemos que, muito provavelmente pautado nestes argumentos, Silva Telles foi levado a sugerir o uso de tirante de ferro substituindo a linha da tesoura que encostava no óculo. Mas, durante o início das obras, foi constatado o mau estado do madeiramento, muito atacado por cupins, e "para evitar o aspecto totalmente novo da armação estamos mantendo as "linhas" em bom estado, inclusive com seus cravos." (LYRA, 1965, p.3) do restante tudo foi refeito facilitando a correção da altura da cobertura.

Isso nos permite a seguinte constatação: os levantamentos realizados anteriormente restringiram-se às soluções arquitetônicas, não incluindo os danos existentes, como por exemplo, a identificação do madeiramento já atacado por cupins. Também existe a falta de registros que identifiquem quais peças estavam danificadas permitindo concluir o que seria necessário para a substituição completa da estrutura. Peças não poderiam ser reaproveitadas? Não poderiam substituir partes das tesouras e caibros? Mas havia um forte incômodo do arquiteto em relação à posição da cobertura, que ele alegava estar mais baixa do que a "primitiva": isso deve ter pesado na decisão final.

Quanto aos espaços internos da igreja, estes foram completamente limpos daquilo que não condizia com o almejado "estado original", portanto todas as pinturas em estêncil do século XIX que decoravam as paredes internas foram suprimidas para dar lugar a pintura à cal, da mesma maneira foram extirpados os 
altares colaterais e o pequeno púlpito localizado na capela-mor, restando apenas o altar principal do século XVIII. Portanto, os elementos considerados posteriores e que não condiziam com a imagem da arquitetura do período Colonial foram eliminados, mesmo aqueles que estavam em bom estado, como, por exemplo, os altares colaterais (Figura 43):

\begin{abstract}
Bem, então eu fui trabalhar com São Benedito contratado pelo Governo do Estado e tive ao meu lado cuidando da parte da restauração do altar e das imagens a restauradora Beatriz Pellizzeti que tinha estagiado, tinha sido discípula de Edson Motta, o grande restaurador do Iphan na época, braço direito de Rodrigo Mello Franco no que se refere a restauração de arte integrada e de bens móveis. Bem, eu comecei o trabalho, o levantamento da igreja, o que tinha que ser feito e intervi dentro de uma linha de intervenção, de restauração restabelecendo elementos que eram elementos originais, por exemplo, a pintura interna da igreja tinha tido em determinada época, no início do século XX tinha sido feita uma pintura, é uma pintura feita com máscaras, de estêncil, uma coisa que não tinha nada a ver com a capela aquela coisa azul que eu eliminei, anos mais tarde, depois eu te conto, alguém cobrou isso de mim. Então eu repintei toda a igreja por dentro de branco, a igreja era amarela, nós repintamos de branco, recompus todo o telhado, troca de telhas, foi muito mais um trabalho de conservação e restauração de determinados elementos. (LYRA, 2012).
\end{abstract}

Muitas das análises de avarias eram realizadas durante as obras, soluções decididas no local, mas sempre com o objetivo final de restabelecer ao edifício suas características originais. Assim como nos outros projetos aqui apresentados, não está claro nos documentos e nas discussões dos técnicos se existia algum critério metodológico com base nas teorias de restauro, isso não está explícito. Percebe-se a partir deste caso que os procedimentos baseavam-se na experimentação e nos exemplos de outras obras realizadas pelos técnicos em diferentes partes do Brasil como veremos logo à frente. 


\section{PARANAGUÁ: IDENTIDADE E PRESERVAÇÃO}

Figura 43: Acima, o encarte sobre a restauração da igreja de São Benedito, publicado em 1967, apresenta algumas fotografias da retirada e reconstrução da cobertura. Nas imagens abaixo fissuras encontradas na parede lateral da igreja em 1967 e a aplicação de presilhas metálicas e cimento para a consolidação das fissuras. Fonte: Acervo IPHAN-PR e IPHAN-SP.
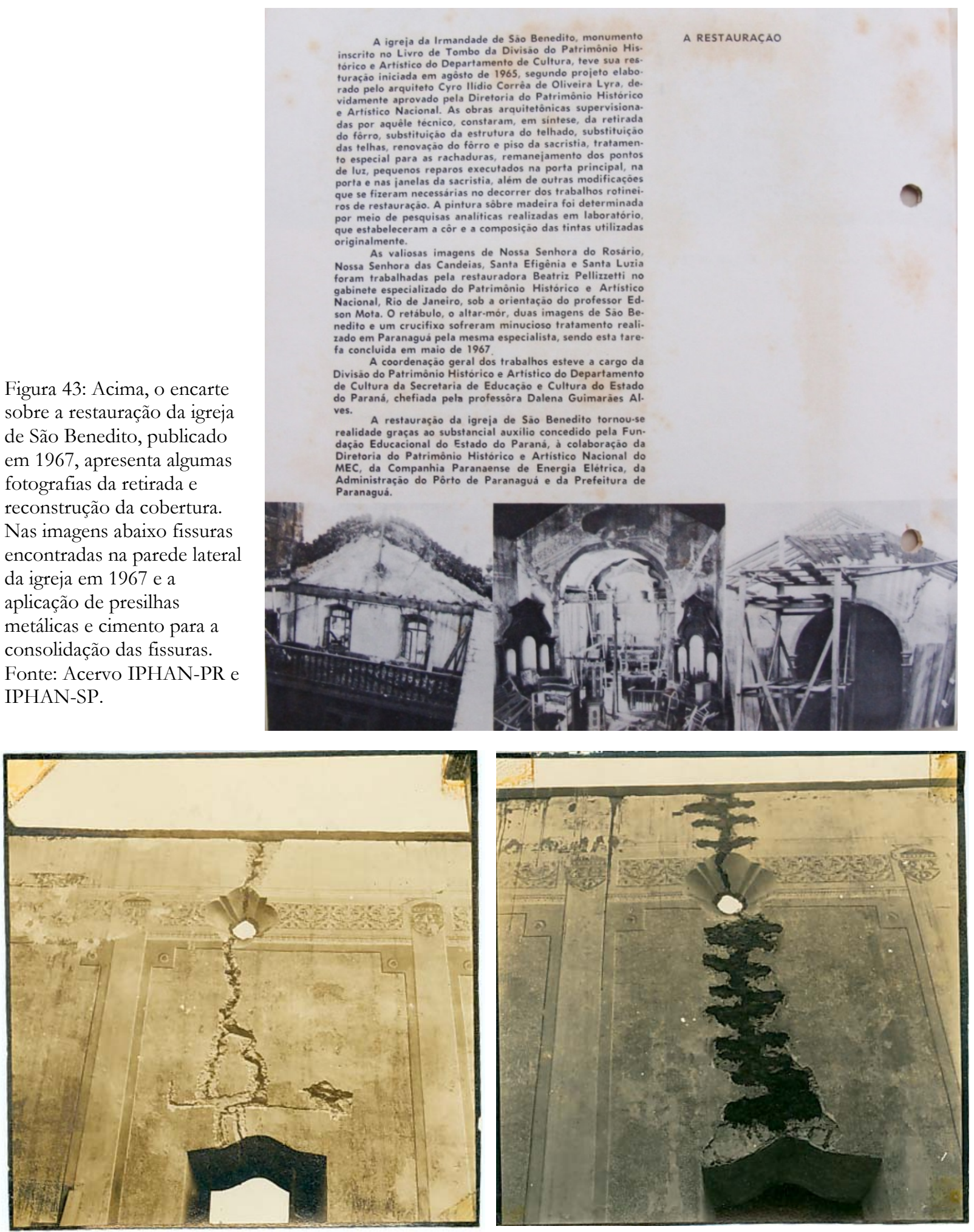


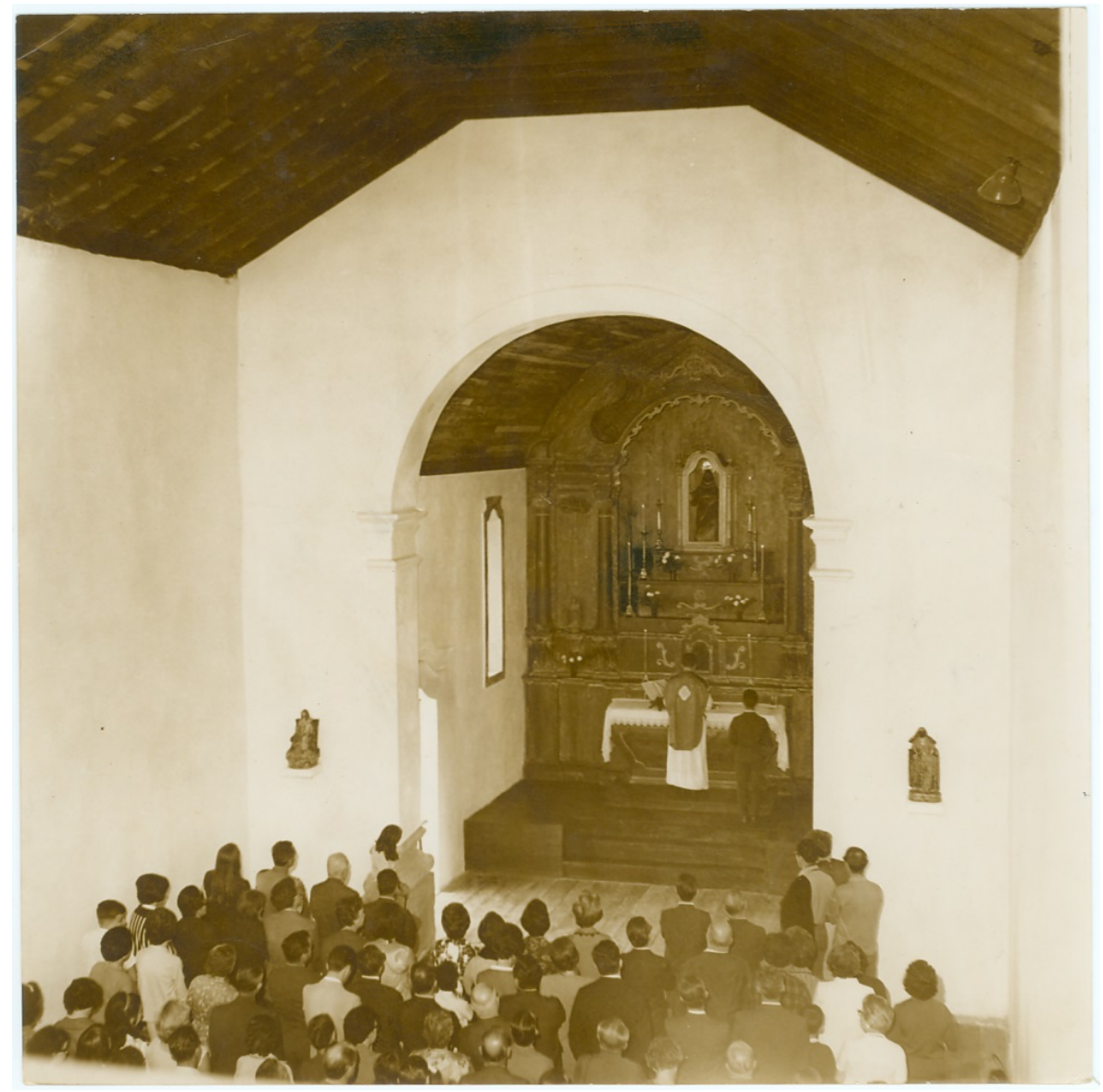

Figura 44: Missa inaugural da restauração da igreja de São Benedito em 1967. A igreja está completamente limpa dos acréscimos oitocentescos. Destaque para as pequenas peanhas nas duas laterais do arco cruzeiro.

Fonte: Acervo IPHAN-PR.

Será válido analisar cada solução de projeto no espaço interno da igreja, são detalhes que permitem avaliar as condições e critérios escolhidos:

O primeiro refere-se aos altares colaterais:

Bem, mas eu inclusive criei uma espécie de peanha, se não me falhe a memória, de concreto, uma plataforminha nas paredes pra botar as imagens, porque eu tirei os altares, acho que tirei, isso pode-se ver nesse artigo que eu vou pegar depois pra você. Se não me falhe a memória haviam dois altares laterais de má qualidade que eu eliminei, tirei e deixei as imagens só na parede e só ficou o altar mor que era do século XVIII como a igreja, que a Beatriz restaurou. (LYRA, 2012).

As pequenas peanhas (Figura 44) em concreto, pintadas de branco, ainda existentes na igreja, foram a solução para a substituição dos altares de madeira, considerados de "má qualidade", que não estavam de acordo com a linguagem adotada no restauro e que teve como objetivo dar o devido destaque ao altar mor e 
ao arco-cruzeiro. Percebemos uma solução de limpeza de elementos considerados espúrios e a adição de um novo elemento muito simples, que permite sua identificação como intervenção contemporânea. Há dois aspectos que devem ser destacados nesta solução, primeiramente a proposta de anulação dos registros físicos de outras épocas, de maneira a permitir apenas a identificação de um período histórico, uma unidade histórica que legitima o ato. Outro aspecto é a adição de dois suportes, que denota a postura do arquiteto na proposta, de modo a dar uma nova leitura do espaço através da utilização da linguagem arquitetônica de seu tempo, eliminou-se um registro, adicionou-se outro. A proposta alterou o uso, não é mais um altar colateral, tornou-se apenas um suporte de imagens sacras.

Quanto ao altar, o restauro ficou sob-responsabilidade de Beatriz Pelizzeti, há claramente um critério nas soluções da restauradora que permitiu a manutenção de registros históricos distintos. Seu relatório de agosto de 1965 constatou a presença de três camadas pictóricas no retábulo, uma mais antiga, uma intermediária e outra provavelmente dos anos 1930. Ainda segundo o relatório, a restauradora sugeriu a retirada parcial das camadas para apresentar os três períodos por meio de decaper, principalmente porque a camada mais antiga não estava completa havendo neste caso a preocupação na manutenção dos registros históricos.

Quanto às outras peças do altar, sua proposta foi a retirada de todo o material pictórico, mantendo a coloração da madeira. Vemos assim que, apesar de não estar explícito qualquer base teórica destes procedimentos, é possível nos reportarmos à teoria de Cesare Brandi (primeira edição de 1963) e à Carta de Veneza (divulgada em 1964) em que é preconizada a manutenção e o cuidado em revelar os registros que permitam a leitura do monumento em todos os seus estratos e na Carta de Veneza, a Carta em seu artigo no 11 estabelece o respeito às contribuições de todas as épocas. Brandi discorre sobre a dupla polaridade, histórica e estética das obras de arte. Por sua teoria, as adições podem ser analisadas pela instância histórica, neste caso [...] um novo testemunho do fazer humano[...] 
(BRANDI, 2005 , p. 71). Vale também lembrar alguns casos italianos de manutenção de camadas pictóricas, como analisado por Carbonara (2006b) sobre o Pallazzo Altemps, exemplo de restauro recente que guia-se pelos preceitos Brandianos. ${ }^{118}$

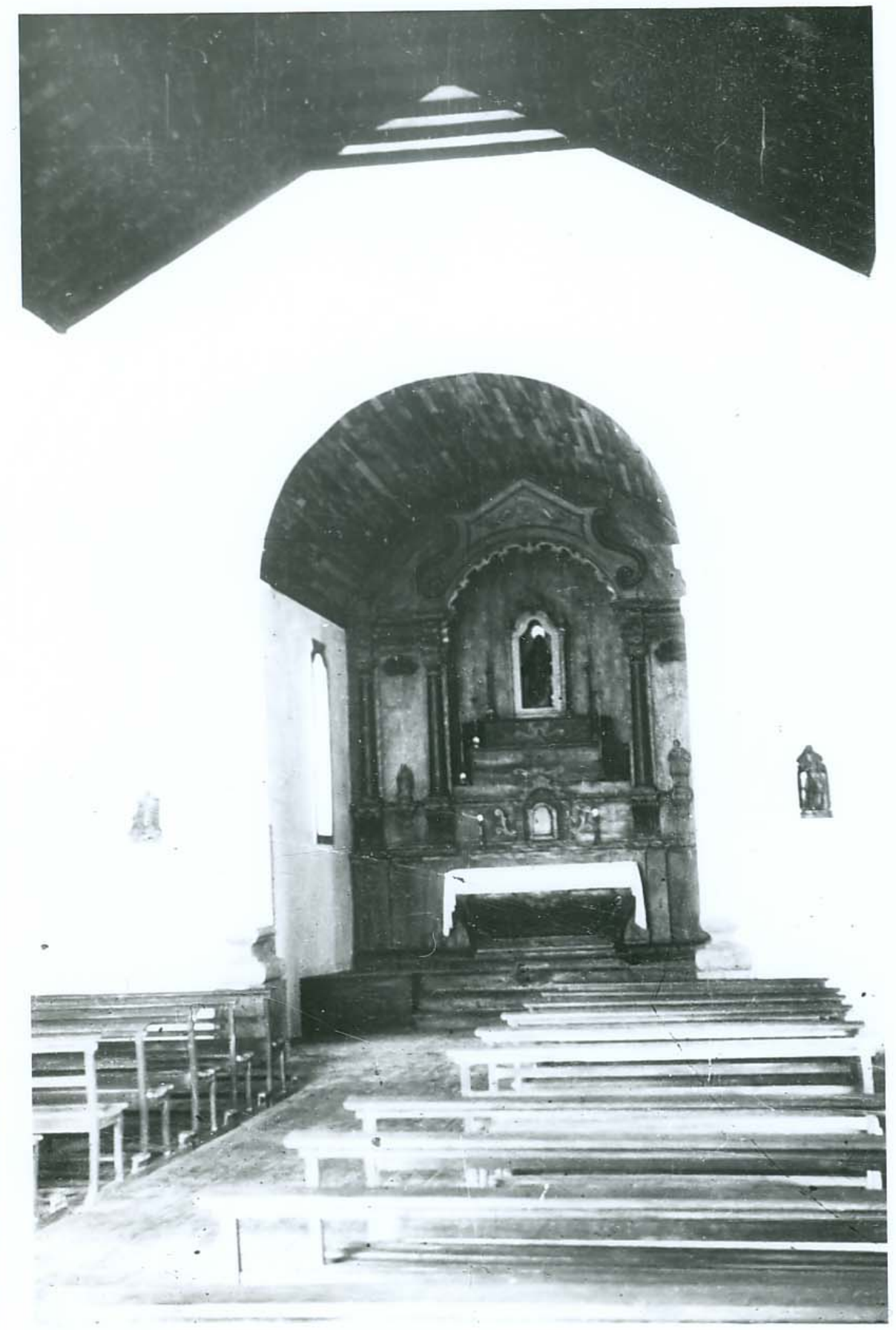

Figura 45: O altar mor restaurado, 1967. Fonte: Acervo IPHAN-PR.

\footnotetext{
${ }^{118} \mathrm{Em}$ nossa visita ao museu, localizado em Roma, as salas de exposição permitem a visualização de extratos pictóricos de pelo menos três períodos históricos distintos, que não apenas revelam técnicas e estilos, mas também sobre o uso daqueles espaços. (visita realizada através da Bolsa de Estágio de Pesquisa no Exterior da FAPESP)
} 
Figura 46: Acima Beatriz Pelizzeti e Cyro Corrêa Lyra, defronte à porta principal da igreja de São Benedito.1966-1967 e abaixo Beatriz iniciando os trabalhos de restauração da imagem de São Benedito. Fonte: Acervo IPHAN-PR.
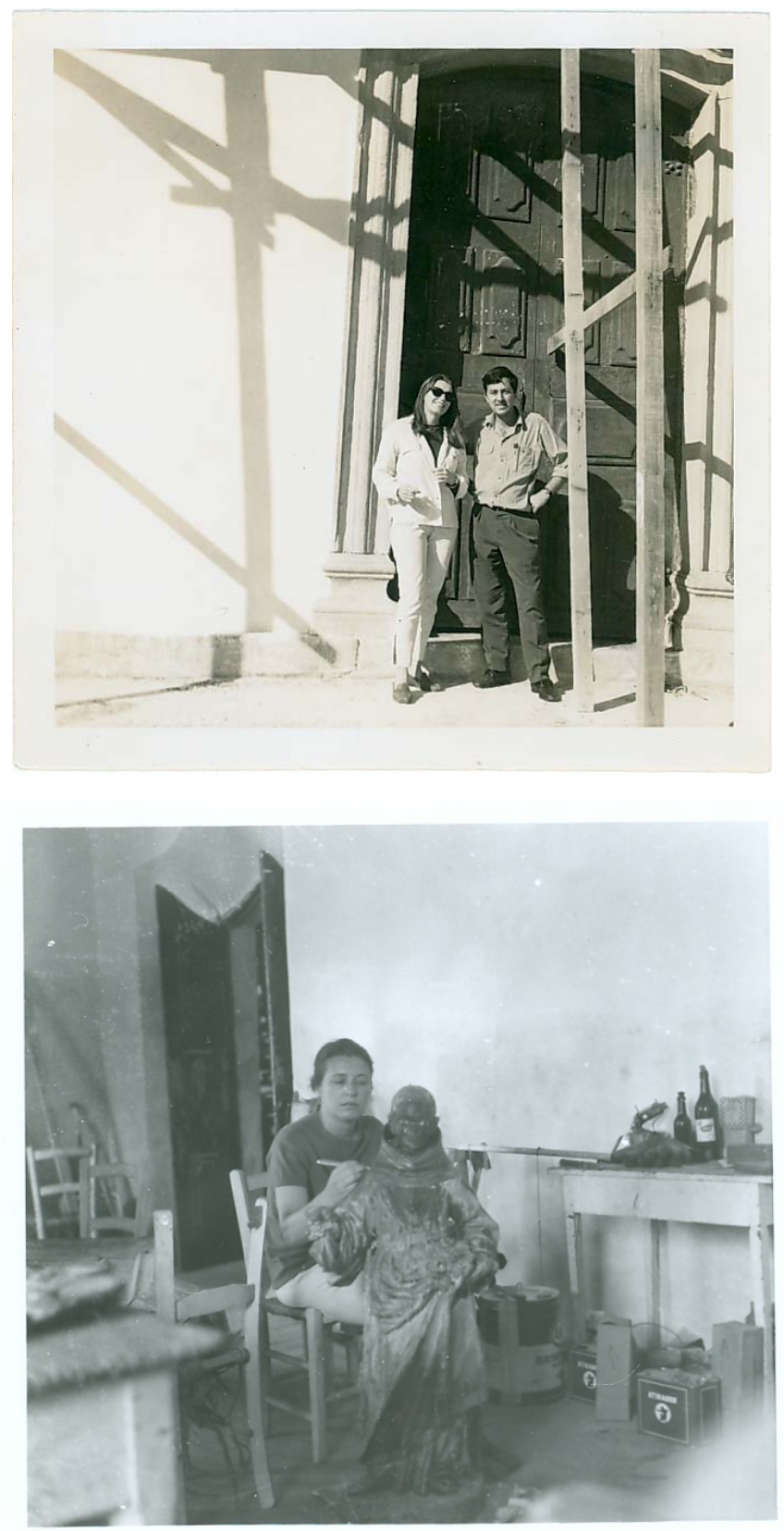

$\mathrm{Na}$ solução adotada para as outras peças do altar, poderíamos facilmente traçar um paralelo com o restauro da igreja do Outeiro da Glória no Rio de Janeiro (década de 1940), em que Lucio Costa propôs a remoção das pinturas das estruturas de cantaria, da mesma maneira a remoção das pinturas dos retábulos, deixando na tonalidade da madeira. Também definiu a retirada de um balcão em ferro fundido localizado na lateral do edifício, pois este prejudicava a leitura da modulação. Foi um projeto que motivou orgulho de seu autor, considerando um “resultado perfeito". Segundo Lucio Costa (1995, p.411): 
A beleza que hoje se vê da estrutura de cantaria contrastando com a caiação, os azulejos, a madeira dos retábulos estava toda encoberta por uma pintura uniforme, as paredes forradas de tabuletas comemorativas de episódios; a camada de tinta que cobria a apurada talha de todos os retábulos era tão espessa que impediu o restauro da pintura primitiva deliberou-se então deixá-los na madeira, restituindo o dourado apenas em certos elementos, como resplendores. E o resultado final ficou perfeito.

Assim percebemos no discurso de Lucio Costa, que a igreja do Outeiro acabou por se tornar um exemplo de êxito nos objetivos da restauração: um padrão! Partindo do pressuposto de que este padrão foi aplicado a outras obras semelhantes sob-responsabilidade do IPHAN, nos perguntamos: existiam outros exemplos de êxito em projetos de restauro que eram apresentados pelos técnicos da instituição? Estas experiências foram aplicadas a outras obras de restauração? Nesse sentido, dados encontrados durante nossa pesquisa, um deles inédito, nos permite ampliar esta discussão na tentativa de responder a estas questões: o primeiro se refere ao texto de Lucio Costa sobre a igreja do Outeiro; o segundo ao artigo de Luís Saia sobre as atividades do IPHAN publicado na revista C J Arquitetura; e o terceiro a uma carta de Augusto da Silva Telles sobre o restauro da igreja da Ordem, que encontramos no arquivo do IPHAN-Paraná.

$\mathrm{O}$ artigo de Luís Saia intitulado Até os 35 anos, a Fase Heroica, publicado em 1977 na revista CJ Arquitetura, trata das experiências no campo da proteção do patrimônio nas primeiras três décadas de atuação do IPHAN. Em seu texto, Saia (1977, p.16), destaca o importante papel dos arquitetos frente à seleção e restauração de monumentos no Brasil:

Os 35 anos de experiência do IPHAN contaram com a participação de arquitetos brasileiros que não possuíam nenhuma formação especializada em restauração, mas cujo conhecimento da arquitetura, permanentemente atualizados pelo estudo do tradicional e do contemporâneo, conduz este trabalho a um nível de profundo respeito pelos documentos do passado e de inegável atualidade na sua formação cultural. 
As experiências de restauração nos monumentos sob a responsabilidade destes arquitetos tornaram-se exemplos que eram utilizados como referências para outras situações semelhantes. Temos como indícios, já discutidos anteriormente na restauração da igreja de São Benedito, em que a proposta para a cobertura baseavase naquela adotada para a igreja de Nossa Senhora do Pilar em Duque de Caxias, no Rio de Janeiro, assim como também foi utilizada para solucionar a cobertura da igreja da Ordem Terceira. Outro dado se refere ao texto, também já comentado nas análises anteriores, sobre a restauração do Outeiro da Glória no Rio de Janeiro de autoria de Lucio Costa, o autor considera o resultado "perfeito" e que certamente se tornou uma importante referência para outras restaurações.

Aproveitando destes dois exemplos comentados e retornando ao texto de Saia, suas colocações destacam a listagem de bens que foram restaurados pelo IPHAN, com "obras completas" (Figura 47). Estes monumentos são citados e discutidos a partir da das regiões brasileiras. O mapa das restaurações empreendidas pelo IPHAN não apenas apontava uma simples lista de monumentos restaurados pela instituição, mas também são modelos referenciais para outras obras de restauração, dentre os quais inclui-se a igreja de Duque de Caxias e o Outeiro da Glória que para Saia (1977, p.18):

$\mathrm{Na}$ Guanabara se encontra o exemplo de edifício no qual a intervenção do Patrimônio Histórico foi realmente decisiva, não apenas naquilo que diz respeito à volta do edifício à sua feição tradicional, estirpando-lhes as coisas espúrias que os desfiguravam, principalmente como oportunidade de um verdadeiro reagenciamento urbano do monumento, num recanto de paisagem carioca que retornou à feição tradicional em que pesem os senões de obras realizadas de modo a não considerar esse monumento.

Neste pequeno trecho, vemos que o Outeiro foi um referencial extremamente importante nas propostas de restauro e que influenciou outras obras do tipo. No Paraná o único exemplo citado foi o Colégio dos Jesuítas, obra que teve a participação de Luís Saia e que também poderia ser citado como uma 
referência, pois é um importante caso de adaptação de uma antiga edificação a um Museu.

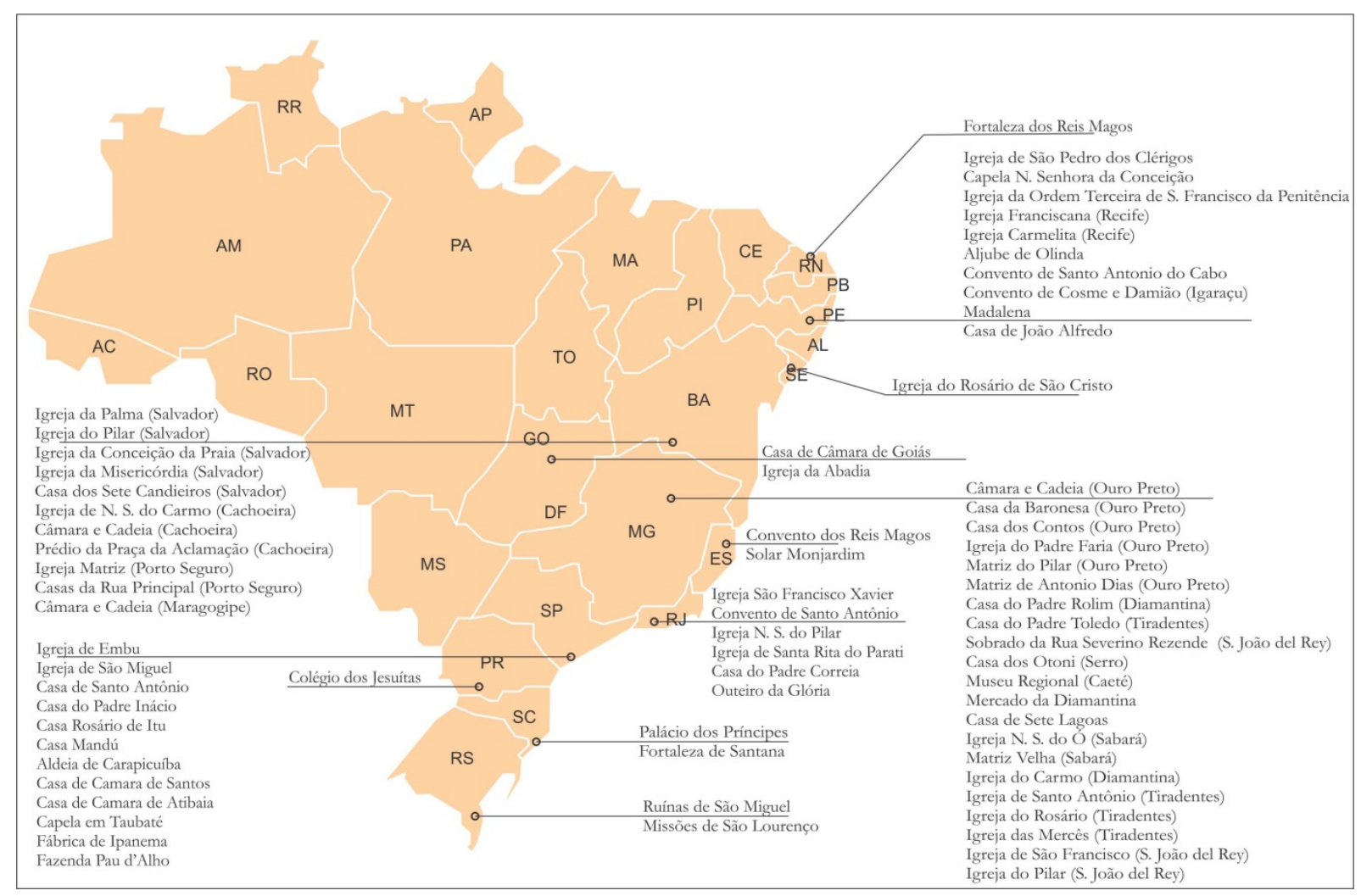

Figura 47: O mapa dos monumentos, baseando- se nas informações encontradas no artigo de Luís Saia (1977). Fonte: Elaborado pelo autor, 2015.

Por outro lado, apesar das soluções de restauro pautadas em outras obras do IPHAN e refletindo sobre as soluções adotadas por Cyro na igreja de São Benedito, será que encontraríamos indícios que fortaleceriam uma conotação teórica pautada nos preceitos do restauro estilístico de Viollet-le Duc?119. Uma das suas prerrogativas é a busca da perenidade, para isso o uso de materiais mais resistentes é fundamental, desde que não prejudicando a composição do monumento. Para os

\footnotetext{
${ }^{119}$ No verbete Restauração, o autor determina, dentre os aspectos do tema, discutido pela primeira vez como disciplina, o caráter da restituição do edifício em sua unidade Para Viollet-Le-Duc a unidade é obtida pelo conhecimento do arquiteto, grande responsável pela restauração, este conhecimento embasa-se nas análises das características dos estilos e das fases que derivaram nas épocas anteriores e posteriores e as características individuais que podem ser resultado da "regionalização" do estilo. Viollet-le-Duc aponta a importância dos registros e documentos que possam garantir o ato da restauração, pois torna-se base para recuperar e reconstituir partes faltantes e alteradas. Anula-se um período histórico de maneira a permitir a tão ensejada unidade estilística. Vale destacar a breve análise de Marco Ciatti (2009, p. 177)sobre o assunto: " Si tratta di uma fase importantíssima per la storia del restauro; il rapporto tra l'opera d'arte e il tempo, che rappresenta sempre uno dei grandi temi, viene valutato diversamente: la storia vissuta dal'opera dal momento della creazione in poi viene considerata come um qualcosa di reversibile, cioè che si può cancellare, ricollegando-si al modo di considerare il restauro, sia al momento della nascita, individuato in base alle conoscenze storiche e ripristinandolo."
} 
técnicos do IPHAN, aparentemente, o concreto foi o material que assumiu esse papel, pois foi recomendado na grande maioria das obras de restauro da fase heroica. Devemos acrescentar que a própria Carta de Atenas de 1931 (2004, pg. 15) reforça essa ideia recomendando a utilização de materiais perenes, mas não se restringindo somente ao uso do concreto, e sim ao "[...] emprego adequado de todos os recursos da técnica moderna [...]".

No que se refere à solução adotada para a cobertura, de acordo com os relatórios, encontramos que foi executada a remoção completa da antiga estrutura em madeira. A nova estrutura é idêntica à antiga, utilizando outro tipo de madeira e com a eliminação de todo o forro, deixando-a aparente. Esta solução de deixar a estrutura aparente foi também adotada na igreja da Ordem. Como já vimos anteriormente, de acordo com o relatório das obras de São Benedito de 1965, a solução adotada tem por base o exemplo da igreja Nossa Senhora do Pilar, localizada em Duque de Caxias, na baixada fluminense. O mesmo recurso da estrutura aparente de cobertura também foi adotado em obras paulistas por Luiz Saia, como por exemplo, a Capela de São Miguel Paulista (restaurada em 1940). Será que podemos analisar o emprego das estruturas aparentes como solução aplicada novamente à teoria leduciana? Discutível tal solução se refletirmos pelas suposições e interpretações que tem por objetivo principal o resgate da "originalidade" 120 . Em geral as igrejas do século XVIII possuíam estrutura de telhado com tesouras em linha alta de maneira a permitir a instalação do forro de gamela.

Pelo aporte da teoria leduciana e a partir dos casos aqui apresentados, a solução adotada pelos técnicos foi de aplicar o mesmo desenho de estrutura. Apesar disso, o forro deveria ser refeito, a partir do que se conhecia sobre a técnica em outras igrejas do período? Outra questão, se houvesse a hipótese da não existência anterior de um forro, qual solução deveria ser adotada? Viollet-Le-Duc

\footnotetext{
120 A solução da estrutura da cobertura aparente, nos faz lembrar as igrejas do gótico italiano, com suas estruturas decoradas, por exemplo, em Florença a Basílica de Santa Croce e a igreja de San Miniato al Monte.
} 
daria uma resposta: "[...] então o arquiteto encarregado de uma restauração deve imbuir-se bem do estilo próprio ao monumento cuja restauração lhe é confiada." (VIOLLET-LE-DUC, 2013, p. 53). Obviamente, sem que isso prejudique a "unidade" do monumento. Dessa maneira, para o caso da cobertura, houve a interpretação e a adoção de um estilo próprio? $\mathrm{Na}$ verdade apenas utilizou-se o mesmo desenho e eliminou-se o antigo forro.

Nesse entendimento, devemos refletir sobre as leituras e interpretações que classificam a ideia de restauro aos moldes leducianos, primeiramente há certos aspectos que colocam sua teoria em discussões sobre as soluções adotadas nas restaurações. No verbete Restauração há certos casos em que as propostas avaliadas diferem-se da ideia geral do autor. O projeto de restauro deve ser avaliado caso a caso, não havendo uma regra geral. Segundo Carunchio (1996, p.38):

Viollet-le-Duc mette in evindeza il fatto che non esistono regole assolute, ma critério-poco più avanti li chiamerà princìpi-quale quello del tornare all'unità stilistica, quando essa sai venuta meno per circostanze sopravvenute, o quello del riprodurre-intenderei "conservare l'immagine", eventualmente rifacendola-le modificazione".

Vejamos por exemplo o caso apresentado por Viollet sobre as capelas laterais construídas posteriormente à construção de uma igreja, neste caso o autor não aponta a necessidade de remoção das estruturas posteriores, mas sua manutenção de maneira a ser perceptível a diferença de épocas entre as duas estruturas, não devemos esquecer que sempre no trabalho de restauro deveria existir o respeito ao estilo, para isso a necessidade de estudos aprofundados e levantamentos que permitam posteriormente estabelecer critérios para o ato prático da restauração (VIOLLET-LE-DUC, 2013). Há também o risco da restauração tornar-se apenas uma cópia integral, Viollet-le-Duc no prefácio de seu dicionário de arquitetura francesa, coloca que nos casos em que há necessidade de reproduzir ou completar partes faltantes, o arquiteto, respeitando o estilo do edifício, deve intervir de maneira autoral:

Tous les monuments enfantés par le moyen âge seraient-ils irréprochables, qu'ils ne devraient donc pas être aujourd'hui servilement 
copiés, si l'on élève un édifice neuf, ce n'est qu'un langage dont il faut apprendre à se servir pour exprimer sa pensée, mais non pour répéter ce que d'autres ont dit; et dans les restaurations, même lorsqu'il ne s'agit que de reproduire ou de réparer des parties détruites ou altérées, il est d'une très-grande importance de se rendre compte des causes qui ont fait adopter ou modifier telle ou telle disposition primitive, appliquer telle ou telle forme [...] (VIOLLET-LE-DUC, 1854, p.15-16).

Ao contrário do que são observadas nas restaurações paulistas, leiam-se aquelas de responsabilidade de Luís Saia, algumas soluções adotadas em Paranaguá tem o caráter de dar ao monumento seu valor de antiguidade. ${ }^{121}$, mas muito ajustado ao gosto do arquiteto. No tratamento de portas e janelas da igreja de São Benedito, folhas novas foram pintadas em azul da Prússia, a cor foi confirmada através da análise de fragmentos nos laboratórios do IPHAN. As folhas antigas foram lixadas e deixadas no tom da madeira, "[...] demonstrando sua antiguidade". (LYRA, 1968, p.17). O valor de antiguidade se faz presente nestes detalhes. Mas esta diferenciação de cores, além de ser um critério confuso, pode prejudicar a unidade potencial do edifício

Há também a substituição das esquadrias das janelas da fachada, de janelas em vidro de abrir para janelas de vidro em guilhotina, seriam substituídas não pela linguagem, pois em sua justificativa considera a solução como característica do século XIX, mas por permitir a melhor iluminação da nave (provavelmente no século XVIII eram janelas almofadadas). Se esta linguagem foi permitida por uma questão de uso, porque os altares colaterais foram retirados por também serem do século XIX? A utilidade sobressai ao caráter de unidade do edifício? Neste caso poderemos nos reportar a um dos exemplos descritos por Viollet-le-Duc no verbete Restauração, em que havia a necessidade de alterações que poderiam permitir ou o melhor conforto dos usuários ou a manutenção do edifício. O exemplo descrito refere-se à necessidade de dispositivos de aquecimento de antigas igrejas medievais. Não seria necessário dissimular “[...] pois os mestres antigos, longe de

\footnotetext{
121 Adotamos o termo utilizado por Aloïs Riegl em sua obra O Culto Moderno dos Monumentos, em que define o valor de antiguidade caracterizado pelas imperfeições e o desagregamento de formas e cores. (RIEGL, 2008)
} 
dissimular uma necessidade, buscavam, ao contrário, revesti-la da forma que a ela conviesse, fazendo dessa própria necessidade material um motivo de decoração." (VIOLLET-LE-DUC, 2013, p. 66)

Ainda que alguns dos procedimentos de restauração, que aqui apresentamos para o caso das duas igrejas, pudessem ter como base teórica os preceitos leducianos, persistem algumas inquietações. Primeiramente, as teorias de restauro não são mencionadas em nenhum relatório ou carta de estudos e de obras nas igrejas, procedimentos que também são reportados em outras pesquisas sobre o tema. ${ }^{122}$ Em segundo lugar, os procedimentos não atendiam a uma única conduta, são soluções que em alguns momentos parecem adotar medidas que têm por base um aporte teórico de restauro, embora não explicitado, e em outros momentos parecem basear-se apenas na própria experiência profissional do arquiteto responsável pelo restauro, soluções pautadas nos discursos da arquitetura moderna $^{123}$.

As obras da igreja de São Benedito são encerradas em maio de 1967, a proposta apresentada em relatório por Cyro foi bem recebida pelos técnicos da Central carioca, como afirmou Renato Soeiro ${ }^{124}$ a chefe da Divisão do Patrimônio Histórico e Artístico do Paraná:

[...] tenho o prazer em comunicar-lhe que produziu excelente impressão nos técnicos desta Diretoria o critério esclarecido e seguro com que o referido arquiteto orientou e conduziu aqueles serviços, como se pode verificar dos informes circunstanciados e das fotografias elucidativas contidas no mesmo relatório.

Com o final das obras, a restauração da igreja de São Benedito foi premiada pelo IAB-Paraná no ano de 1967 e sua descrição foi publicada na revista

\footnotetext{
122 Sobre o assunto ver ...

123 Sabe-se que os técnicos responsáveis pelas obras de restauração naquela época eram arquitetos que atuavam no mercado de trabalho e paralelamente a isso demonstravam interesses ou afinidades com a preservação, não havia arquitetos especialistas na área de restauro atuando no Brasil.

${ }^{124}$ Carta de Renato Soeiro a chefe da Divisão do Patrimônio Histórico e Artístico do Paraná, Dalena do Guimarães Alves em 3 de novembro de 1965. (Arquivo IPHAN-PR).
} 
Arquitetura de junho/julho de 1968. Na missa inaugural, esteve presente Rodrigo Melo Franco de Andrade. A imagem restabelecida, na fachada, não alterou seu aspecto, se compararmos com fotografias anteriores, a grande alteração refere-se à cor, do amarelo para o branco, que foi constatada nas prospecções. Já o espaço interno, com suas decorações oitocentistas, foram extirpadas, dando lugar a uma igreja limpa de elementos decorativos, quase uma obra moderna.

O que pretendemos apresentar nesses dois casos, tanto na igreja da Ordem quanto na igreja de São Benedito, é que os critérios de restauração não estavam embasados estritamente nas teorias de Viollet-Le-Duc ou na Carta de Atenas e muito menos na Carta de Veneza. Em nenhum momento, dentro das justificativas de projeto apresentados, houve a menção a estas questões. Em ambos os casos aqui analisados, as propostas foram embasadas em padrões, em obras que os técnicos consideravam bons exemplos a serem seguidos, como a "perfeita" restauração do Outeiro da Glória.

Não podemos afirmar que havia desconhecimento dos técnicos frente às teorias, pois elas circulavam entre as instâncias do Serviço do Patrimônio, como foi descrito na entrevista de Silva Telles, há também um texto de Lucio Costa que cita Viollet-le-Duc e suas análises sobre o gótico ${ }^{125}$ e devemos acrescentar também a entrevista com Cyro Corrêa Lyra sobre as restaurações de Saia em que ficou visível a preocupação com o equilíbrio na composição dos monumentos como na restauração do Forte de Santana em Santa Catarina. Nos casos aqui apresentados, os registros dos levantamentos do estado dos monumentos, arquivados no IPHAN, são basicamente fomentados pelas fotografias e breves textos. Quando da restauração, ao mesmo tempo em que eram identificados os problemas, sejam eles estruturais ou de cunho estético, já eram também discutidas as soluções, seja em esboços, ou fotografias ou muito raramente em projetos com peças gráficas. Tudo se dá pela experimentação ou a partir do conhecimento de outras experiências,

\footnotetext{
125 No texto Muita Construção, alguma arquitetura e um milagre, de 1951. In: COSTA, Lucio. Lucio Costa: Registro de uma Vivência. São Paulo: Empresa das Artes, 1995.
} 
casos que se tornam base para outras obras, são soluções aplicadas a outros casos a partir destas referências que deram certo na opinião dos técnicos.

Nas reflexões sobre a preservação no Brasil, Beatriz Kühl (2011) destaca a falta de critérios e referências sobre restauro pelos profissionais do IPHAN, apresentando como justificativa as parcas discussões sobre a temática nas publicações da instituição na Fase Heroica. Outro porém se encontra nas teorias em uso naquele período como a Carta de Atenas e os preceitos de Viollet-Le-Duc. Segundo a autora:

O que transparece nas intervenções do SPHAN é, na verdade, o empirismo, tendo como meta a valorização de um período específico de nossa história. Desse modo, em relação aos vários paralelismos com o ambiente francês do século XIX (e a outros ambientes europeus daquele período - e também latino-americanos na virada do século XIX para o XX -, em que se tentava construir a ideia de nacionalidade), é difícil comprovar se são fruto de uma real filiação a sistemas de pensamento sobre restauro ou se, na verdade, provêm de uma aproximação fortuita, resultados de semelhanças dos processos de construção de identidade, que se aproximou, em certos aspectos, ao que ocorrera na Europa. (KÜHL, 2011, p. 108).

Empirismo que se mescla com outras experiências que se tornaram base para as soluções adotadas, como foi o caso dos restauros promovidos pelos arquitetos cariocas, que de certa maneira, diferem-se das propostas paulistas, mais ligadas às experiências de Saia. Há soluções que tornaram-se um padrão, por exemplo, apesar da mudança das técnicas construtivas dos monumentos tombados, da taipa de pilão e da pedra e cal, foram mantidos o uso do cimento, seja em estruturas de concreto armado ou nas argamassas - estrutura e revestimento. Recomendação da Carta de Atenas, mas com a seguinte ressalva: "Especificam, porém, que esses meios de reforço devem ser dissimulados, salvo impossibilidade, a fim de não alterar o aspecto e o caráter do edifício a ser restaurado." (CARTA DE ATENAS, 2004, p.15). Há ainda o exemplo do uso do cimento em obra de restauração apresentada pelo engenheiro Nicholas Bolanos para o projeto do Parthenon em Atenas, a técnica da anastilose foi, em conjunto, utilizada com a reposição de peças faltantes 
de tambores das colunatas confeccionadas em concreto. Anteriormente entre os anos de 1929 a 1934 o superintendente Alberto Terenzio executou as restaurações utilizando-se de tijolos, semelhante aos novos, mas cinzelados na face em vista, de maneira a ser identificável, mais apropriado que o uso do concreto. O material também foi adotado em obras italianas como o Arco de Constantino e o Capitólio de Brescia. (CARBONARA, 2006a).

Em entrevista, o arquiteto Augusto da Silva Telles faz uma análise valiosa dos trabalhos empreendidos por Luís Saia e que utilizaremos para os casos aqui apresentados. Quando questionado sobre a política da Pedra e Cal propagada pelo IPHAN Telles (2010, p.120) respondeu:

Pedra e cal, barro e madeira. Agora, havia realmente uma preocupação, por exemplo, para o Luís Saia, em São Paulo, onde não existia pedra e cal, restava o barro e madeira. Mas ele não tinha essa preocupação com a construção sólida. No resto do Brasil, Bahia e o resto, todos têm essa preocupação com a obra sólida.

Em outro trecho aponta que: "O Saia via as obras no sentido de espaço e de ligação delas com a comunidade." (TELLES, 2010, p.120). Parece que a "matéria" não era o único elemento essencial nas posturas dos arquitetos da Fase Heroica frente à restauração, mas o resultado plástico, o espaço. Nestas obras a almejada imagem final, da busca do original, da tradição, que não é obtido apenas pela ordem física, mas de vertente estética, o fim é a imagem pura da arquitetura Colonial, enquanto a matéria era suporte dessa imagem.

No que se refere à preocupação com o entorno do edifício, se faz presente nas cartas em que os técnicos analisam a ambiência, tema caro nas discussões e que nos permite iniciar o terceiro capítulo. Percebemos uma relação entre a discussão de ambiência dos três edifícios tombados pelo IPHAN: Colégio dos Jesuítas, igreja de São Benedito e igreja da Ordem com a delimitação do centro histórico de Paranaguá. 


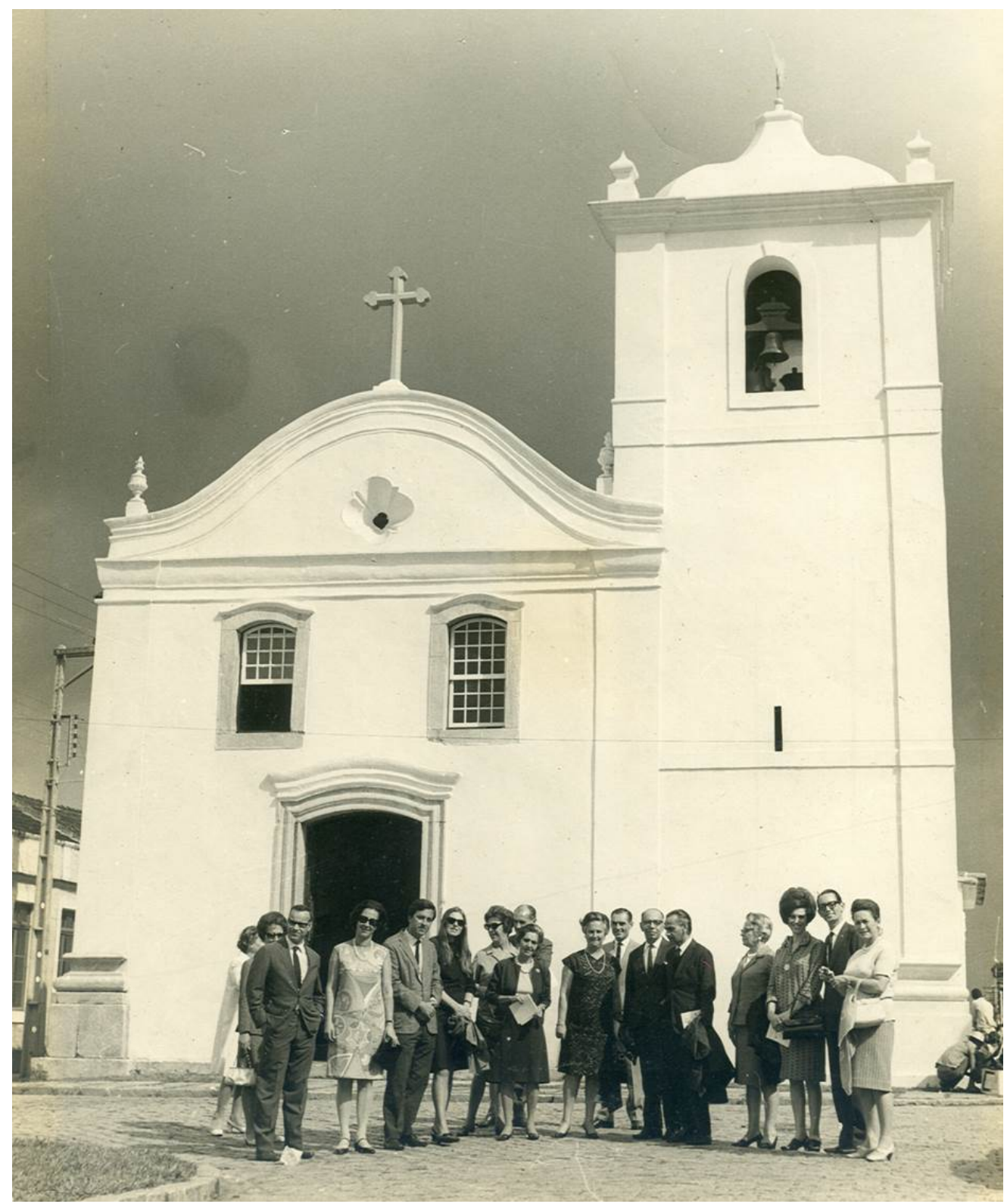

Figura 48: Inauguração da restauração da igreja de São Benedito em 1967. Estão na fotografia 1. Enio Marques Ferreira; 2. Dalena Guimarães Alves, 3.Cyro Correa Lyra; 4. Beatriz Pelizetti; 5. D. Graciema, esposa de Rodrigo Melo Franco de Andrade; 6. Newton Carneiro; 7.

Professora Porcia Guimaraes Alves, irmã de Dalena; 8. Rodrigo Melo Franco de Andrade; 9. Renato Soeiro; 10. D. Judite Martins, secretária do Sphan; 11. Esposa do Prefeito de Paranaguá; 12. Prefeito Nelson Barbosa e 13. D. Elza Carneiro, esposa de Newton Carneiro. (A identificação foi possível graças a Cyro Corrêa Lyra). Fonte: Acervo de Cyro Corrêa Lyra

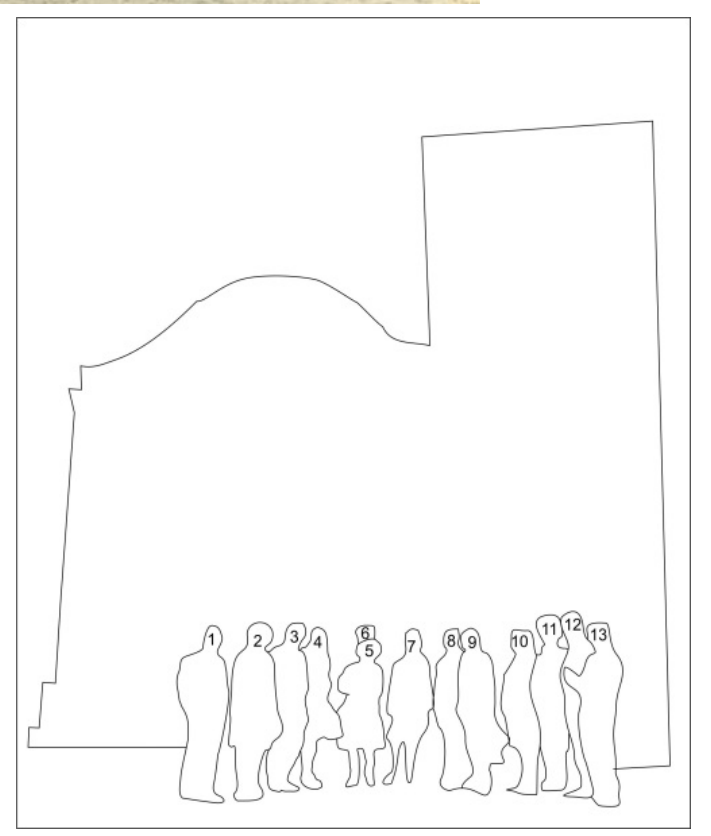




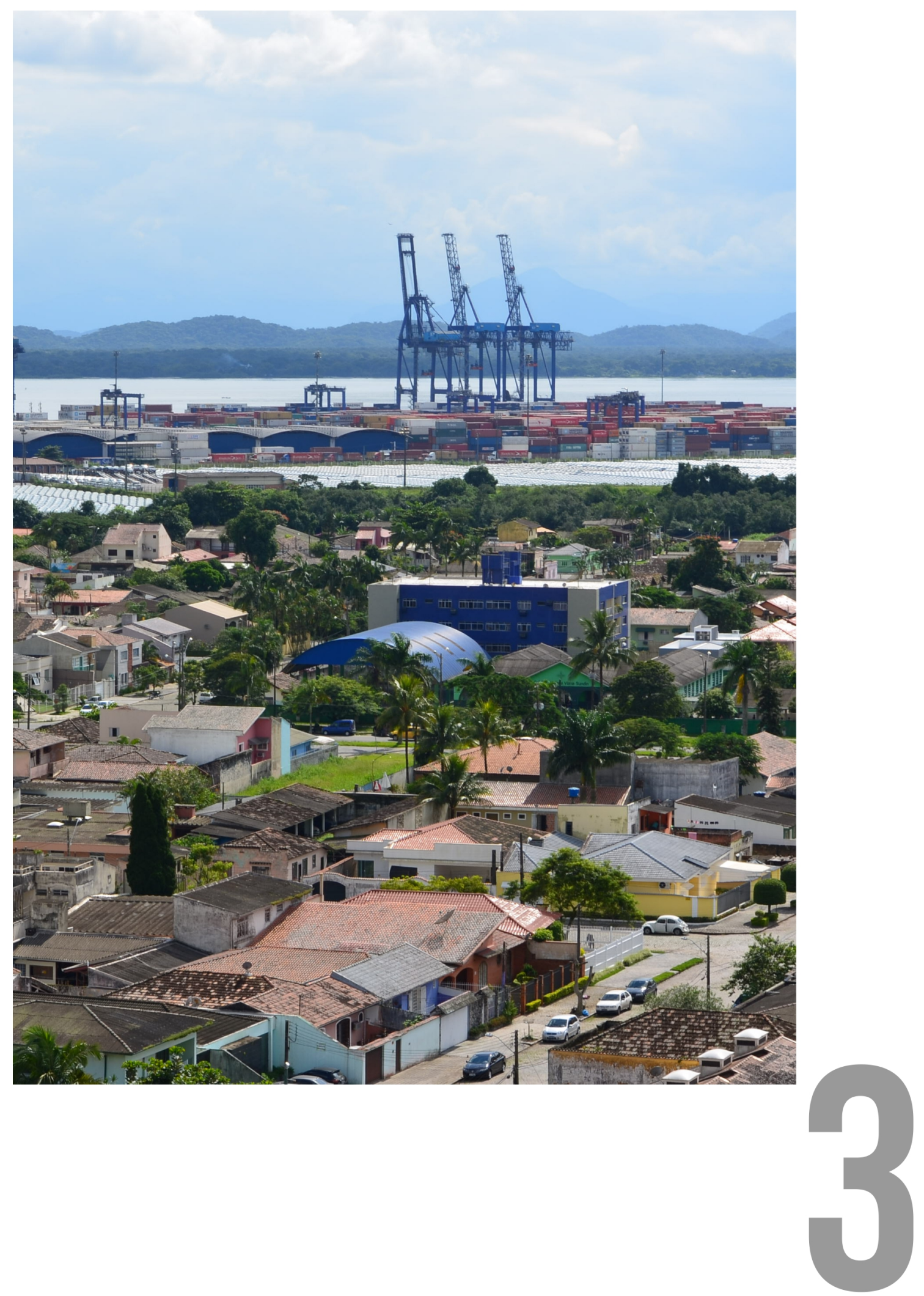





\section{CApítulo 3 - do plano de 1968 aO tOMBAmENTO de 2009: CENTRO HISTÓRICO DE PARANAGUÁ}

As propostas de proteção do patrimônio de Paranaguá não se restringiam apenas aos edifícios isolados, pois também terão reverberações no conjunto urbano, a partir de estudos que definem e delimitam o centro histórico da cidade. Deste modo, é essencial compreendermos as atividades de proteção relacionadas à área urbana de Paranaguá, contribuindo no panorama das ações do IPHAN e da rede de relações entre as figuras-chave.

As primeiras iniciativas referentes à preservação do conjunto urbano de Paranaguá são da década de 1960. Em anos anteriores, as ações que mais se aproximavam destes conceitos de proteção de áreas históricas foram constatadas nas propostas elaboradas pelos técnicos do IPHAN para ampliar a proteção dos monumentos tombados: Colégio dos Jesuítas, igreja de São Benedito e Ordem Terceira de São Francisco das Chagas, a partir da definição de áreas envoltórias. É importante lembrar que o reconhecimento de conjuntos urbanos como monumentos no Brasil tem por ponto de partida a cidade de Ouro Preto e sua chancela de Monumento Nacional em 1933 pela Inspetoria de Monumentos Nacionais e cinco anos depois, com a criação do órgão federal de proteção do patrimônio, com mais cinco cidades mineiras: Mariana, Tiradentes, Diamantina, Serro e São João del Rey. (SANT'ANNA, 1994).

Neste capítulo, apresentaremos o processo que desembocou no tombamento federal do centro histórico de Paranaguá, iniciado a partir da primeira delimitação elaborada ainda nos anos de 1960 por Cyro Corrêa Lyra, sem perdermos de vista a rede de relações que foi determinante, notadamente para a inserção da cidade no contexto de atividades dos estudiosos da UNESCO que vieram ao Brasil neste período. A rede de relações estabelecida nos primórdios do Serviço do Patrimônio 
será mantida até os anos de $1970^{126}$, mas terá reverberações em décadas posteriores, principalmente pela atuação de Cyro, que é uma figura-chave nesse panorama parnanguara.

Analisar as circunstâncias em que se deu a proteção do centro histórico de Paranaguá contribui para compreendermos as políticas de preservação do IPHAN, especialmente no Estado do Paraná, que sofreu grandes mudanças não só estruturais, mas administrativas, por exemplo, a política de descentralização do órgão, iniciada na gestão de Renato Soeiro e os impactos nos períodos de crise quando Fernando Collor esteve na presidência do Brasil. Além disso, este capítulo inclui a análise de ações locais que foram decisivas na resposta às ameaças às quais o patrimônio de Paranaguá estava sujeito.

A partir do número de tombamentos referentes a áreas urbanas nas três primeiras décadas de funcionamento da instituição, na denominada Fase Heroica (1937-1969), percebemos a grande variedade de escalas de proteção, que vão desde a cidade por completo a pequenos extratos na malha urbana, trechos de ruas, praças, largos e monumentos isolados. É necessário destacar que o tombamento, da maior parte das cidades, entendidas como conjunto em sua totalidade, ocorreu logo nos anos de 1930 e todas eram mineiras ${ }^{127}$. Neste sentido, em outro período importante, a década de 1950, houve considerável número de registros de trechos urbanos, a maior parte deles concentrados na região Nordeste: em Salvador, o tombamento de praças e seus entornos (Praça Ana Nery, Praça Severino Vieira) e conjuntos de subdistritos (Sé, dos Mares, Conceição da Praia, Penha); em São Luís, várias praças (Praça Benedito Leite, Praça Gonçalves Dias, Praça João Francisco Lisboa); e em outras regiões, como Paraty, Vassouras (Rio de Janeiro) e Pilar de Goiás (Goiás) houve o tombamento do conjunto urbanístico e paisagístico. Portanto, os anos de 1950 e 1960 são assinalados por um maior número de

\footnotetext{
126 Foi o fim da gestão de Rodrigo Melo Franco (1967), e o falecimento de Luís Saia (1975) e de José Loureiro Fernandes (1977).

127 Os dados foram retirados da publicação organizada pelo IPHAN que cataloga todos os bens móveis e imóveis tombados entre os anos de 1938 a 2009. Para saber mais ver: LIMA, Francisca Helena Barbosa; MELHEM, Mônica Muniz e POPE, Zulmira Canário. (Org.). Bens Móveis e Imóveis Inscritos nos Livros do Tombo do Instituto do Patrimônio Histórico e Artístico Nacional 1939-2009. 5ªEd. Rio de Janeiro: IPHAN/COPEDOC, 2009.
} 
tombamentos envolvendo apenas trechos de áreas urbanas, enquanto que são pouquíssimas as contempladas com o tombamento em sua totalidade.

A partir desses dados, é possível afirmar que a preservação de conjuntos urbanos não foi o foco principal dos tombamentos na Fase Heroica se comparados, por exemplo, com o número de registros de monumentos isolados. Os debates internacionais sobre a preservação de trechos urbanos e as legislações sobre o tema terão mais força nas décadas do Pós-Guerra. Isso não significa que o tema estivesse fora dos debates em anos anteriores, pois o primeiro documento internacional que tratou do assunto, a Carta de Atenas, é de $1931^{128}$, e apontava a preocupação na preservação dos entornos dos monumentos, tema precioso nas discussões entre os técnicos do IPHAN e contido nas propostas de restauro dos edifícios parnanguaras. ${ }^{129}$

A ambiência foi tema presente nas atividades da instituição e merece uma análise a partir dos monumentos tombados em Paranaguá ${ }^{130}$. No panorama brasileiro, assim como o tombamento dos edifícios representativos da nação, as cidades históricas serão selecionadas a partir dos mesmos pressupostos, a predileção pela arquitetura mineira do século XVIII, consequentemente, gerando o expressivo número de conjuntos urbanos setecentistas mineiros tombados na Fase Heroica. Nos outros casos apresentados anteriormente, nos apontam para a

\footnotetext{
128 A Carta de Atenas de 1931 destaca a preocupação com o entorno de monumentos e até abrangendo aspectos do "valor de antiguidade", por exemplo, no controle da vegetação em conjuntos urbanos de modo a manter "seu caráter antigo". Há também a sugestão para a restrição da publicidade, da fiação elétrica e outros elementos que podem ser prejudiciais ao monumento. Não devemos negar o pioneirismo dos italianos frente ao tema, pois os estudos de Gustavo Giovannoni inspiraram a elaboração da Carta de 1931, pois também esteva participando da Conferência em conjunto com outros estudiosos italianos e foi responsável pela primeira teoria urbanística voltada para preservação das áreas antigas das cidades. (CARBONARA, 2006a).

${ }^{129}$ Neste panorama da preservação urbana, é importante salientar a contribuição italiana naquele período. A Itália dos anos 1960 foi marcada pelo crescimento das cidades e alguns autores analisam os problemas resultantes deste crescimento. Por exemplo, Alfredo Barbacci (1896-1989) analisou o crescimento da cidade e sua consequente expansão para as colinas, este crescimento afetava as visuais e o caráter paisagístico de uma cidade de extrema importância estética e histórica. (BARBACCI, 1962). Franco Minissi enfatiza a participação popular nas obras e nas atividades realizadas nas áreas históricas. Define a participação da sociedade nos processos de proteção, denominando de "Conservação Ativa" de maneira a provocar o interesse em sua conservação e o caráter de responsabilidade ante aos monumentos. (MINISSI, 1978).

130 A discussão sobre ambiência deve ser tratada, pois está muito presente nas cartas trocadas entre os técnicos, é tema que faz parte do cotidiano das obras de restauração, tanto no caso das igrejas da Ordem e São Benedito como também no Colégio Jesuíta.
} 
preservação de pequenos trechos, praças e envoltórias de monumentos importantes, que também tem por objetivo proteger a ambiência.

Em Paranaguá, o enfoque na proteção da ambiência é constatado já no final dos anos de 1950, durante a restauração do Colégio dos Jesuítas, em função das possíveis ameaças representadas por edifícios lindeiros ao monumento. O edifício do Colégio quase completa toda a quadra em que está implantado, restando apenas três lotes: um voltado para a rua XV de Novembro em que está situado o Instituto Histórico e Geográfico de Paranaguá numa edificação do século XIX que não oferecia apreensão aos técnicos do IPHAN. Os outros dois lotes eram voltados para a rua General Carneiro e são o foco desta análise (Figura 49). Tornam-se objeto de discussão entre as figuras-chave durante as obras de restauração, isso devido ao interesse de José Loureiro Fernandes em favor da aquisição dos lotes: um deles estava vazio e o outro com duas casas térreas. Sua proposta era que "[...] um recanto verde contra o Colégio e a muralha seria algo de magnífico e quer me parecer que não exigiria grande obra." ${ }^{131}$ A ideia foi bem recebida por Renato Soeiro, mas houve um embate, justamente porque as casas existentes haviam sido demolidas e uma nova construção estava sendo iniciada. No entanto, foram feitas denúncias à central do IPHAN e tomadas providências através de telegramas, solicitando medidas à Prefeitura Municipal para que criasse dispositivos que impedissem aquela construção, chegando até a Rodrigo Melo Franco comunicar ao Procurador da República o embargo da obra. Mesmo assim, nenhum destes recursos impediu que a construção continuasse.

A preocupação também recai sobre o lote de esquina, pois existia a possibilidade de início de uma construção residencial de dois pavimentos, José de Souza Reis (1909-1986) ${ }^{132}$ em seu relatório apontava para o risco que a obra poderia ocasionar na ambiência do monumento:

\footnotetext{
${ }_{131}$ Carta de José Loureiro Fernandes a Rodrigo Melo Franco de Andrade em 15 de setembro de 1958.

132 Arquiteto do período Moderno, foi um dos primeiros colaboradores de Rodrigo Melo Franco, é autor do Panteão dos Inconfidentes no Museu da Inconfidência em Ouro Preto e foi autor de uma das propostas para as rampas de acesso ao Outeiro da Glória no Rio de Janeiro. Para saber mais ver: ROCHA, Ricardo. José de Souza Reis e o SPHAN: da inconfidência à glória. In: $7^{\circ}$ Seminário DO.CO.MO.MO Brasil - O Moderno já passado/O Passado no
} 
O projeto em apreço afeta as condições de visibilidade e ambiência do antigo Convento dos Jesuítas, hoje Museu de Arqueologia, pois, localizado em terreno da mesma quadra, ainda que na esquina oposta da rua Cel. João Estevão ficaria, entretanto, a uma distância de cerca de 15 $\mathrm{m}$ do edifício tombado. ${ }^{133}$

Figura 49: Localização dos lotes e o Colégio Jesuíta em imagem aérea de 2014, o lote 1 estava vazio, o lote 2 e 3 ocupados.

Fonte: Google Earth, 2014; Adaptado pelo o autor,2015.

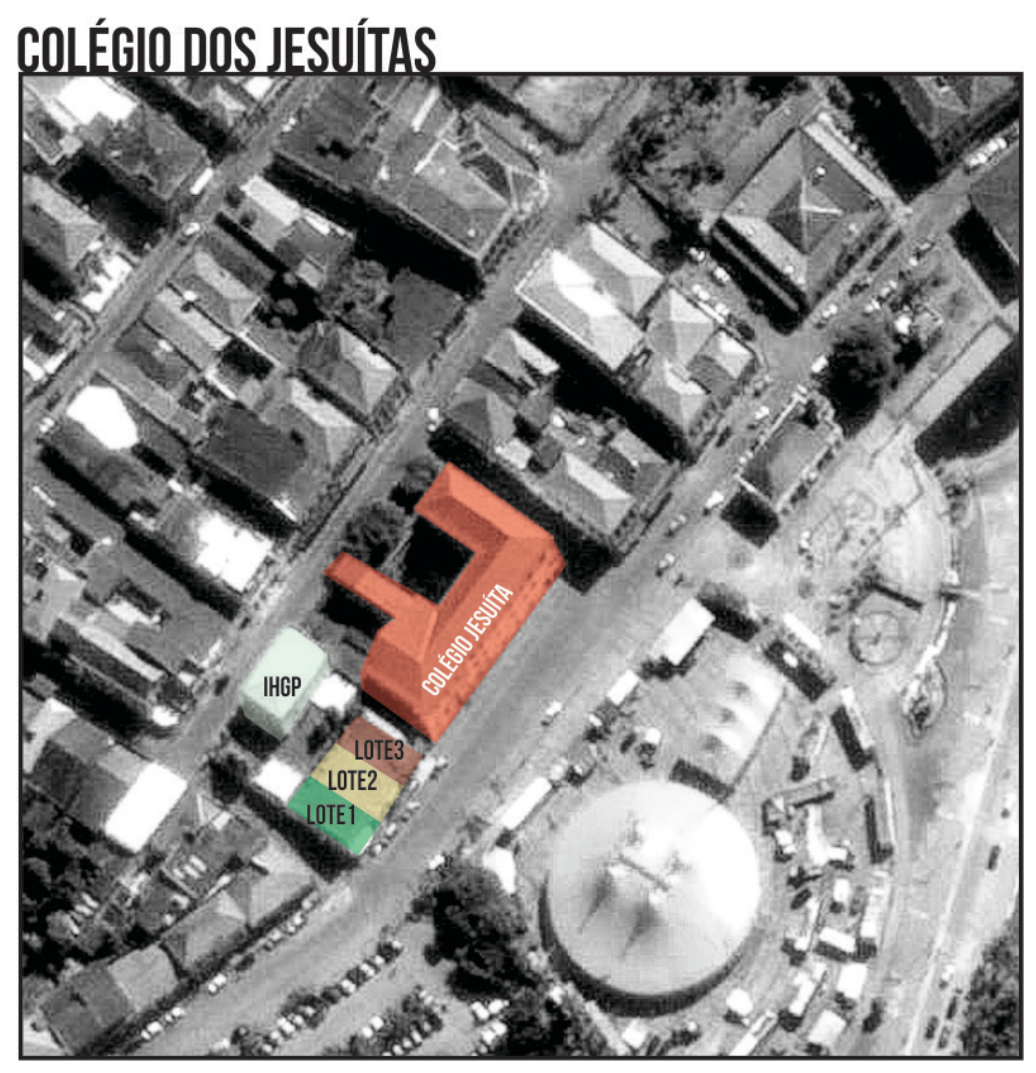

Vale destacar quais os objetivos alegados pelos técnicos para a desapropriação dos terrenos contíguos ao Colégio Jesuíta, por exemplo, em carta do diretor Renato Soeiro:

O objetivo deste órgão é a eliminação daquelas construções inadequadas à vizinhança do monumento tombado e que perturbam o conjunto arquitetônico da antiga residência dos Jesuítas na sua fachada voltada para o rio Itiberê, assim como, posteriormente, de acordo com as necessidades, seu aproveitamento para construção condizente destinada à instalação da administração e novas dependências do estabelecimento. ${ }^{134}$

moderno: reciclagem, requalificação, rearquitetura, 2007, Porto Alegre. Anais do $7^{\circ}$ Seminário DO.CO.MO.MO Brasil, 2007.

133 Relatório de José de Souza Reis de 31 de maio de 1960. (Arquivo Central)

${ }^{134}$ Carta de Renato Soeiro ao Diretor do Departamento de Cultura do Estado do Paraná Ennio Marques Ferreira em 3 de novembro de 1967 (Arquivo Central). 
A ideia de monumento isolado está presente na justificativa de Renato Soeiro sobre a desapropriação dos terrenos:

O museu de Arqueologia e Artes Populares, de Paranaguá, PR, funciona no antigo Colégio dos Jesuítas, monumento inscrito nos livros do Tombo desta diretoria, em convênio entre MEC e a Universidade Federal do Paraná. Existem, na mesma quadra do Museu, três pequenas propriedades particulares que impedem a expansão do Museu e que the prejudicam a ambiência e a aparência monumental. ${ }^{135}$

O termo ambiência, presente nestes documentos, nos parece ter por objetivo principal tratar o edifício tombado como ponto focal, elemento referencial naquele contexto urbano. É a partir da ambiência que se tem a ideia de proteger sua aparência monumental. Estas discussões são contemporâneas a dois importantes documentos internacionais de proteção do patrimônio: a Carta de Veneza que destaca a valorização e a proteção de sítios urbanos e rurais; e a Norma de Quito que tem temas relacionados à proteção da paisagem, não deixando de lado a importante relação entre espaço e monumento, ou seja, não separando uma da outra:

A ideia do espaço é inseparável do conceito de monumento e, portanto, a tutela do Estado pode e deve estender-se ao contexto urbano, ao ambiente natural que o emoldura e aos bens culturais que encerra. Mas pode existir uma zona, recinto ou sítio de caráter monumental, sem que nenhum dos elementos que o constitui, isoladamente considerados, mereça essa designação. (NORMAS DE QUITO, 2004, p.106).

Apesar das discussões sobre a preservação de áreas urbanas já ser difundida naquele período, aparentemente a ideia de monumentalidade, discutida pelos técnicos do IPHAN está ligada ao discurso do urbanismo moderno em detrimento das discussões mais recentes sobre o tema. No caso do Colégio dos Jesuítas, a discussão parece dar mote à ideia do monumento isolado, que também se deve à escala do edifício, de grandes proporções. Assim como no edifício jesuíta, as duas

135 Carta de Renato Soeiro ao Ministro do Estado de Educação e Cultura Tarso Dutra em 10 de abril de 1968. (Arquivo Central) 
igrejas tombadas pelo IPHAN em Paranaguá, foram tema de discussão sobre a ambiência contida nas propostas de restauração elaborada pelos técnicos. A igreja da Ordem situa-se numa esquina (Rua XV de Novembro e Rua Prisciliano Correa) limitada por edifícios em uma das laterais e aos fundos (Figura 50). Durante o processo de tombamento, que se desenrolou por pelo menos uma década, o arquiteto Cyro Correia Lyra, na obra de restauração executada em 1965, propõe que o possível tombamento federal se estenda ao terreno limítrofe e ao edifício na lateral, para [...] desde já, resguardar sua posição. "(LYRA, p. 1, 1965). O tombamento estadual ampliou a área de proteção para o terreno fronteiro ao monumento, onde hoje situa-se uma praça que se encerra à beira do rio Itiberê.

Figura 50: Localização da igreja da Ordem, em vermelho.

Fonte: Google Earth, 2014; Adaptado pelo o autor,2015.

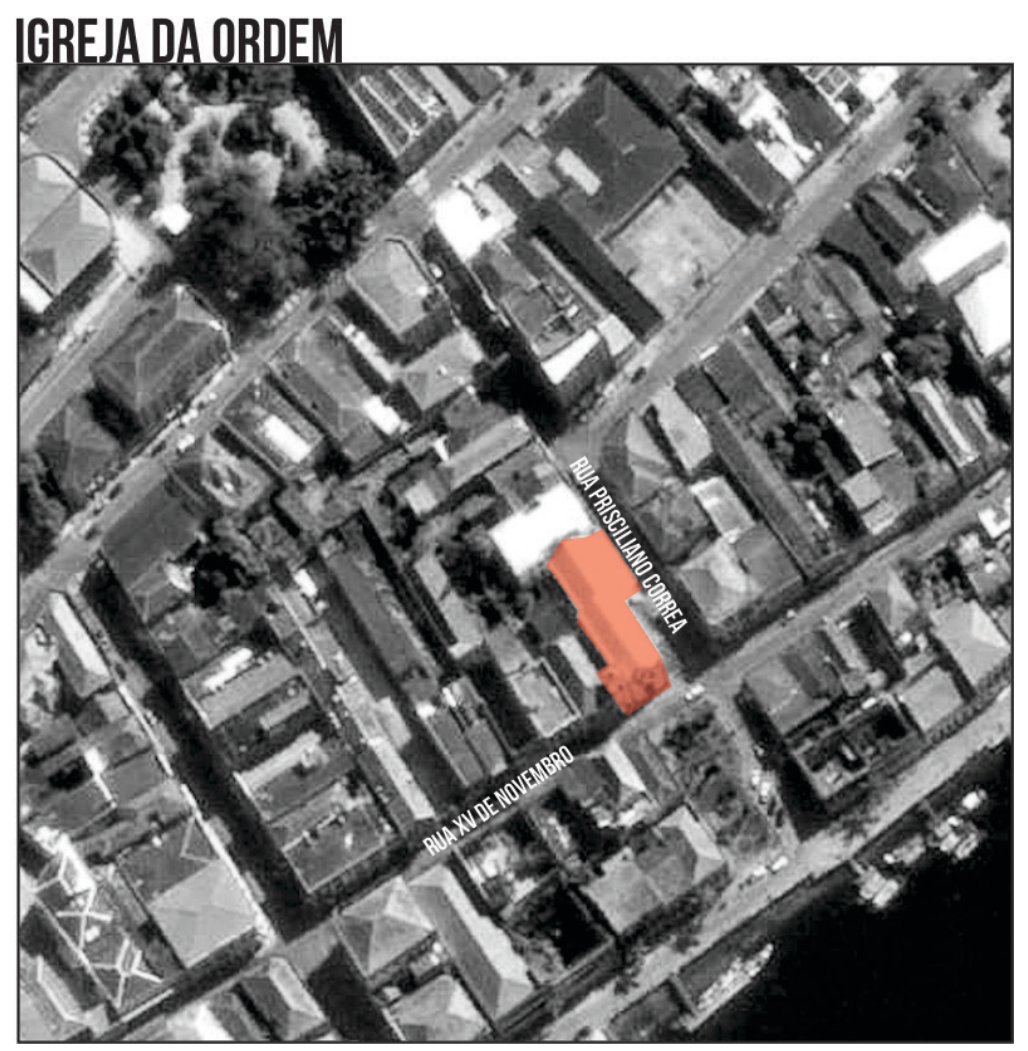

Em outro momento há o alerta ao IPHAN sobre obras que eram executadas no edifício situado aos fundos da igreja. Foi constatada a abertura de janelas na face voltada para o pátio lateral do monumento, local em que estão alguns túmulos da irmandade. $\mathrm{O}$ ocorrido foi reportado ao $4^{\circ}$ Distrito em São Paulo para medidas cabíveis, segundo documento, as aberturas poderiam "[...]interferir na 
ambientação[...]" e estavam em desacordo com a legislação municipal relativo aos recuos exigidos para abertura de vãos. Apesar de enviar comunicados à prefeitura sobre o caso, nada foi solucionado e as janelas foram abertas. ${ }^{136}$

Já no caso da igreja de São Benedito, existe uma característica que a diferencia dos outros edifícios tombados em Paranaguá, sua implantação ao fim da Rua Conselheiro Sinimbú, ponto focal desta via, a peculiar característica de implantação também tornou-se tema dos debates entre os técnicos que apoiavam a ideia de preservar não só o monumento, mas também sua implantação (Figura 51). Em 1964, consta no texto da proposta para o restauro da igreja, também elaborado por Cyro Corrêa Lyra, um item que se refere ao "tratamento paisagístico", que estava associado ao discurso de ambiência propagado pelos técnicos:

Como medida indispensável, deverá ser estudado o remanejamento das áreas circunvizinhas; com a extensão das áreas gramadas e de passeio, revisão da iluminação ao redor, preservação do casario colonial, ainda intacto das proximidades. Finalmente, como medida básica para a salvaguarda do conjunto, o tombamento da área circunvizinha, dentro de um raio de alcance a ser estudado. ${ }^{137}$

Na proposta também consta a solução adotada para o reservatório de água que faz parte da rede de abastecimento de Paranaguá, localizado aos fundos da igreja de São Benedito e que pode ser observado em algumas de suas perspectivas. Cyro propôs não eliminar, mas sim ocultar, a partir do plantio de árvores ao fundo da igreja e pintar o reservatório de cinza azulado, de modo que não houvesse grande impacto nas visuais do monumento, principalmente a partir da Rua Conselheiro Sinimbú. Outro item proposto foi o corte das árvores do canteiro central da rua possibilitando a visual do edifício como ponto focal. ${ }^{138}$

\footnotetext{
136 Carta de Cyro Correa Lyra ao Chefe substituto do Distrito do IPHAN em São Paulo de 23 de fevereiro de 1978. Carta de Armando Rebollo ao prefeito de Paranaguá José Vicente Elias em 27 de fevereiro de 1978. (Arquivo IPHAN-SP).

${ }^{137}$ Relatório sobre a situação atual da igreja de São Benedito de autoria de Cyro Correa Lyra em 25 de maio de 1965. (Arquivo IPHAN-PR).

${ }^{138}$ Dados retirados da Revista Arquitetura de junho/julho de 1968.
} 
Figura 51: Localização da igreja de São Benedito e aos fundos o reservatório d'água.

Fonte: Google Earth, 2014; Adaptado pelo o autor,2015.

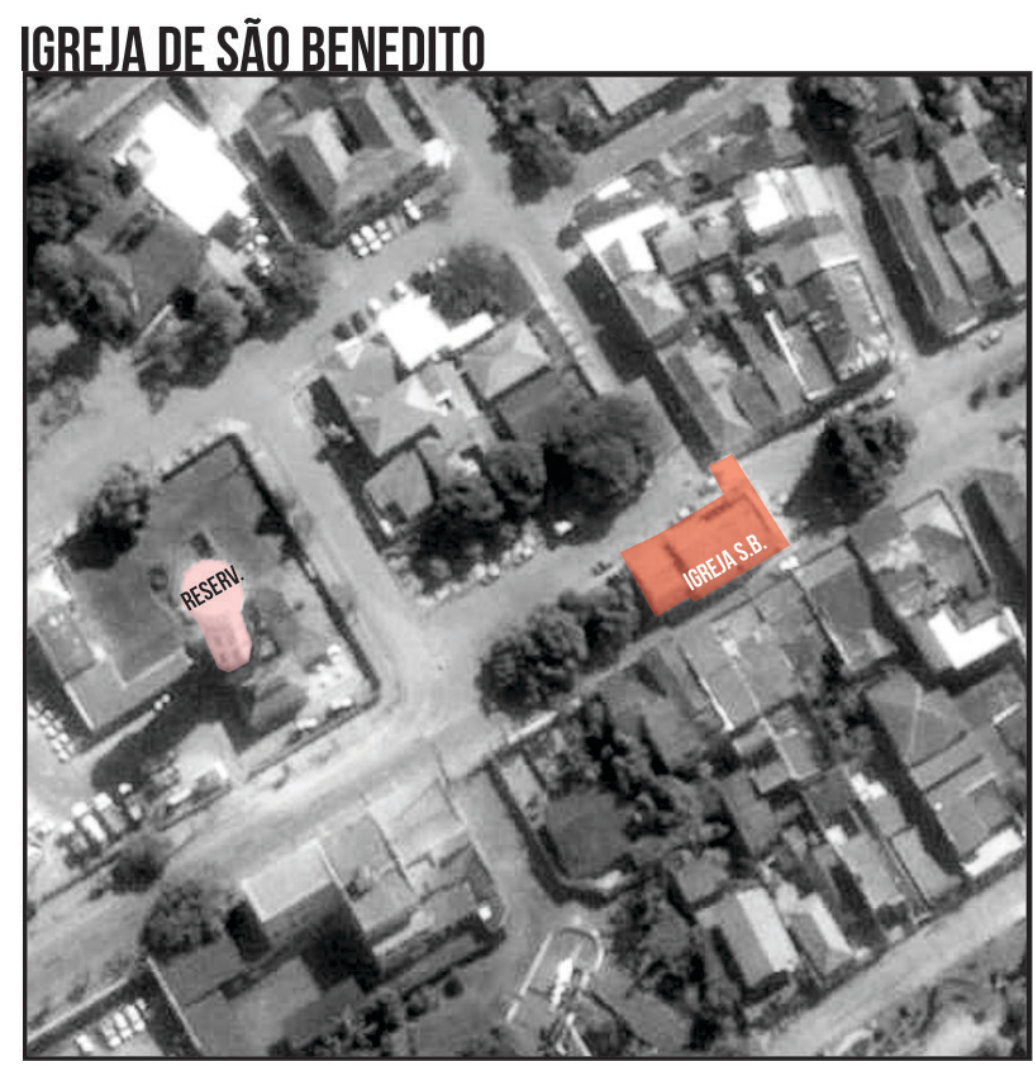

Podemos perceber que, a proposta para a Igreja de São Benedito, não se referia apenas ao edifício, mas também expandindo a proteção para o casario existente em seu entorno, esta proposta torna-se mais abrangente do que nos dois casos anteriores, que se deve à peculiaridade de sua implantação. Temos provavelmente a influência da Carta de Veneza, pois além da ideia de preservação dos edifícios próximos ao monumento, houve a manutenção de construções que poderiam afetar a percepção da igreja, e o emprego de recursos que permitiam sua leitura sem que isso prejudicasse as estruturas essenciais da cidade como poderia ter ocorrido, caso optassem pela demolição do reservatório de abastecimento de água.

Nas propostas apresentadas pelos técnicos para os monumentos parnanguaras, a ambiência está relacionada à proteção da imagem do monumento, não está presente nestes discursos a ideia de retorno ao original, como nas propostas elaboradas para a restauração de monumentos isolados. A proteção da ambiência parece não se associar com a ideia de retorno ou manutenção das 
características originais, mas sim de proteger a imagem do edifício tombado, de proteger sua monumentalidade.

Portanto, as discussões de ambiência dos monumentos tombados pelo IPHAN em Paranaguá foram condicionantes para a primeira delimitação de uma poligonal de proteção do centro histórico elaborada por Cyro Corrêa Lyra que teve como base o estudo realizado pelo arquiteto belga Fréderic de Limburg-Stirum, analisada com mais detalhes no capítulo seguinte. 


\subsection{MISE EN VALEUR: AS INFLUENCIAS INTERNACIONAIS E A PROTEÇÃO DO PATRIMÔNIO URBANO DE PARANAGUÁ PELO PLANO DIRETOR DE 1968.}

Em Paranaguá, apesar dos diversos registros relativos à preservação de monumentos isolados tão precocemente, a primeira ação que veio a tratar do conjunto urbano só aconteceu em fins dos anos de 1960, a partir dos estudos empreendidos pelo Governo do Estado do Paraná e que resultou na elaboração do Plano Diretor de Paranaguá, pioneiro sob a temática de centro histórico no país. O papel de figuras-chave neste caso também foi essencial na elaboração do Plano e, novamente, envolveu o professor José Loureiro Fernandes. Há também que se compreender o contexto pelo qual um arquiteto belga, a serviço da UNESCO, foi à Paranaguá com o propósito de elaborar o primeiro plano que delimitou o setor histórico da cidade. Entre os anos de 1960 e 1970, a UNESCO iniciou pesquisas em diversos países com o objetivo de aprofundar o conhecimento sobre o patrimônio cultural, e no caso brasileiro, estreitou laços com o IPHAN, propiciando a vinda de estudiosos ao país com o propósito de prestar auxílio técnico. (LEAL, 2008). Um dos notáveis deste grupo foi Michel Parent, que visitou uma dezena de cidades no Brasil, incluindo Paranaguá, infelizmente não encontramos, exceto no seu relatório ${ }^{139}$, outra menção à esta visita.

Foi extremamente importante na década de 1960, as discussões e iniciativas, principalmente na Europa, que definiram, nas áreas urbanas, zonas de proteção histórica. O principal documento que trouxe grandes contribuições para o campo disciplinar da restauração é a Carta de Veneza, o alcance do documento no Brasil tem como um dos responsáveis, Michel Parent (1916-2009). Ele defendeu a realização de extensos tombamentos, inserindo também as pequenas construções

\footnotetext{
139 Relatório intitulado Proteção e Valorização do Patrimônio Cultural Brasileiro no Âmbito do Desenvolvimento Turístico e Econômico.
} 
nesse contexto e o incentivo ao fomento do turismo cultural. Sua vinda marcou o estabelecimento de novas políticas para a preservação aplicadas ao SPHAN. (SANT'ANNA, 1995).

Outra figura notável na disseminação e discussão da Carta de Veneza no IPHAN foi o arquiteto Augusto da Silva Telles. Como vimos anteriormente, foram promovidas discussões sobre o tema na Central do Serviço do Patrimônio e na Diretoria paulista, de acordo com a importante declaração, localizada na entrevista de Silva Telles ${ }^{140}$ Há de se observar neste valioso trecho da entrevista, as referências que os técnicos partilhavam nas propostas de restauração. Os técnicos privilegiavam os conceitos da Carta de Atenas, neste raciocínio vamos observar que a partir do caso de Paranaguá, existe uma forte tendência das experiências francesas, que veremos posteriormente na proposta para a organização do plano diretor e a delimitação do centro histórico. Fica perceptível pelo depoimento de Silva Telles que as teorias italianas não estavam dentre as requisitadas pelos técnicos do Serviço do Patrimônio, muito influenciados pelas figuras-chave que formavam o corpo técnico do IPHAN.

O próprio Rodrigo Melo Franco de Andrade adotou, de maneira ainda tímida, a postura da Carta Italiana no que se refere à proteção de monumentos, nessa compreensão é importante citar um breve trecho de seu discurso na Abertura das Comemorações da Semana da Independência, em abril de 1966:

Mas não devemos restringir o nosso zelo às relíquias ligadas aos grandes homens da pátria e sim velar pela conservação escrupulosa da integridade do espólio que herdamos da cultura material dos nossos antepassados, em Minas Gerais e em todo o território nacional. Por desleixo, falta de educação suficiente e mal entendido ânimo progressista, a população mineira e a do Brasil inteiro já sofreram perdas tão graves quanto injustificáveis daqueles bens culturais produzidos e deixados por nossos maiores. Chegou desde muito o momento de não mais ceder, mas resguardar e proteger com a maior firmeza, sem vacilação alguma, um patrimônio cultural, que não pertence apenas a seus proprietários imediatos, mas igualmente à coletividade brasileira e à própria comunidade universal, cada dia mais alerta em chamar a contas as nações

\footnotetext{
140 Entrevista com Augusto da Silva Telles realizada em 2009 por Analucia Thompson, Lia Motta, Irene da Silva Telles e Jurema Arnaut. O trecho está na página 41.
} 
desidiosas na conservação dos respectivos monumentos históricos e artísticos. (ANDRADE, 1987, p.179)

Paranaguá, no que se refere à preservação do conjunto urbano, estava inserida no panorama nacional e estão fortemente influenciadas pelas experiências internacionais, pois não só foi incluída no rol de cidades visitadas e analisadas por Michel Parent, como também foi alvo de uma proposta de planejamento do arquiteto belga Frederic de Limburg-Stirum. A vinda de Limburg-Stirum ${ }^{141}$ a Paranaguá se deve à intermediação de Rodrigo Melo Franco ${ }^{142}$ quando em 4 de novembro de 1966, encaminhou uma carta de apresentação a José Loureiro solicitando que recebesse o arquiteto e o acompanhasse na visita ao Museu de Arqueologia. Não foram encontradas cartas posteriores que registrem desdobramentos sobre a visita do arquiteto belga, mas em entrevista realizada por e-mail com Limburg-Stirum ${ }^{143}$ e em entrevista com Cyro Correa Lyra foi possível avançar nesta questão. Há também que lembrar da Chefe da Divisão do Patrimônio Histórico e Artístico do Paraná, Dalena Guimarães Alves ${ }^{144}$, que já estava envolvida na restauração das igrejas da Ordem e São Benedito e que sondou o arquiteto “[...] para apresentar sugestões referentes a um plano de urbanização para a cidade antiga de Paranaguá.” (PARENT, 2008, p.147). Em 1966, Limburg-Stirum elaborou um estudo para Paranaguá que, conforme os depoimentos obtidos, se tornou a base para o Plano Diretor de 1967. Cyro Corrêa Lyra (2012) ${ }^{145}$, que conviveu com o arquiteto na ocasião, nos declarou que:

[...] ele era uma pessoa que tinha dinheiro e por diletantismo ele fazia sugestões e propunha, como ele propôs para Paraty, como ele fez, falava de Paranaguá, ele não chegou a fazer um plano para Paranaguá ele fez essas notas que eu não tenho.

\footnotetext{
141 Arquiteto belga, formado na École Speciale d' Architecture em Paris, veio ao Brasil na década de 1960 onde estabeleceu contato com Rodrigo Melo Franco de Andrade e foi responsável por desenvolver o plano para a cidade de Paraty, publicado pela UNESCO em 1968.

142 Em entrevista realizada por e-mail em 19 de março de 2015, Limburg-Stirum disse que após seus estudos sobre Paraty, Rodrigo Melo Franco decidiu lhe enviar à Paranaguá para elaborar um estudo preliminar de desenvolvimento urbano.

143 O e-mail foi respondido em 15 de março de 2015.

${ }^{144}$ De acordo com Limburg-Stirum a visita à Paranaguá foi guiada por Dalena Guimarães Alves e um funcionário da prefeitura, de quem ele não recorda o nome.

${ }^{145}$ Entrevista realizada com o arquiteto Cyro Correa Lyra em 14 de agosto de 2012 no Rio de Janeiro.
} 
O estudo intitulado: Notes pour Elaboration d'um Plan d'Urbanisme de Paranaguá, consistia num conjunto de desenhos como descreve Lyra (2012):

Não, ele não fez um plano de Paranaguá, ele fez uns esboços exatamente chamando a atenção[...] esse croqui que é meu, eu que desenhei, é um pouco dentro do que era a linha dele, quer dizer, você criar uma área de amortecimento dos prédios grandes [...]
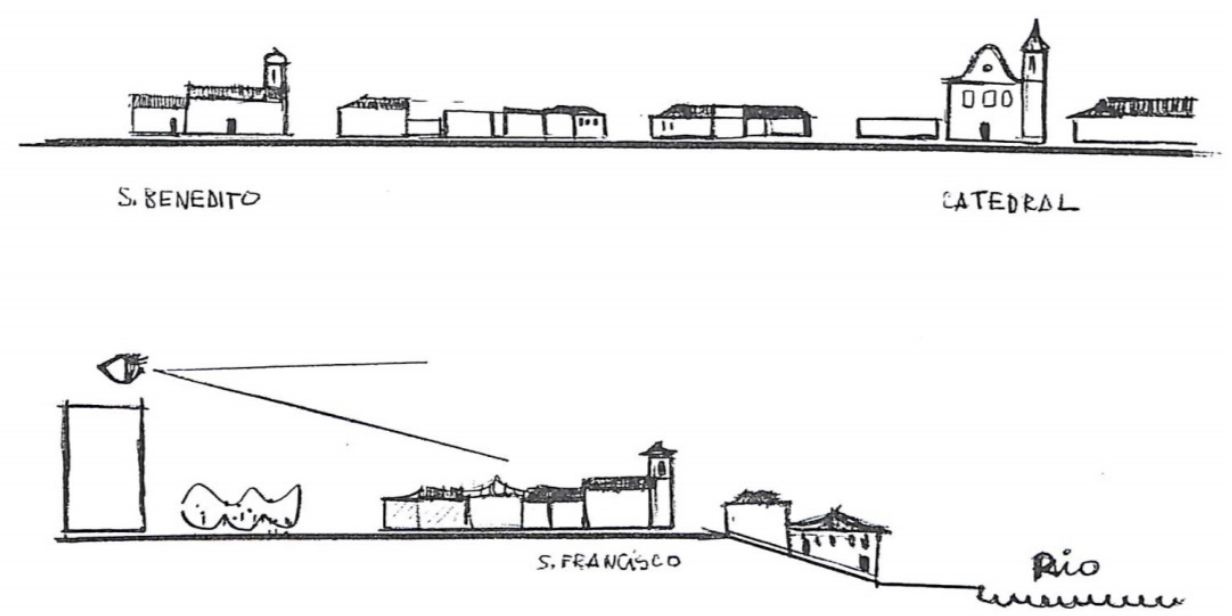

Figura 52: Croquis de Cyro Corrêa Lyra Manutención da excala para o Plano Diretor de Paranaguá. URBouna $\rightarrow$ preservação Fonte: do centro histónico PARANAGUÁ, 1968

Desse modo, nos perguntamos o que motivou a vinda de Michel Parent e Fréderic de Limburg-Stirum especificamente a Paranaguá? Sabemos que a cidade não estava nas prioridades das políticas federais de preservação do patrimônio, mas, no relatório elaborado por Parent, Paranaguá foi incluída na análise juntamente com importantes cidades, tais como Salvador, Recife e Ouro Preto. Vale observar que nenhuma cidade paulista foi avaliada, apesar da notável figura do Diretor Regional Luís Saia (1911-1975). As relações estabelecidas entre Rodrigo Melo Franco e José Loureiro Fernandes aliadas ao bom resultado que o Museu de Arqueologia já apresentava, muito provavelmente influenciaram na visita dos estrangeiros. Portanto, vemos muito claramente a rede de relações contribuindo para inserir Paranaguá nas políticas federais de preservação. 
Lamentavelmente os esboços de Limburg-Stirum não foram localizados em nenhum dos arquivos consultados ${ }^{146}$. Entretanto Michel Parent ${ }^{147}$ descreveu parte das ideias apresentadas, dando destaque ao tema no capítulo de seu relatório em que trata da região Sul. Pelo estudo de Limburg-Stirum, o centro da cidade foi dividido em três áreas, o bairro histórico, a área Non altus tolendi e a área de expansão moderna. O bairro histórico compreendia a área balizada pelos seguintes edifícios: a Chácara do Caju ${ }^{148}$, a Fonte da Gambôa, a igreja de São Benedito e a rua Conselheiro Sinimbú, a Matriz, o Colégio dos Jesuítas, o cais do velho porto que seria a rua da Praia, a igreja da Ordem, a antiga residência do Visconde de Nácar e a rua XV de Novembro que sofreu muitas alterações mas que manteve sua volumetria. (PARENT, 2008). A área chamada Non altus tolendi dividiria o bairro histórico da área de expansão moderna, com edificações mais baixas, situada atrás do bairro histórico. A área de expansão poderia receber edifícios mais altos e, quanto maior fosse o afastamento do bairro histórico, maiores alturas seriam permitidas.

Limburg-Stirum também elaborou outra proposta, mais completa, a da cidade de Paraty, intitulada Plan national de mise en valeur de Paraty dans le cadre d'un développement touristique (1968), onde propôs a separação do centro histórico da área de expansão através de um "cinturão verde" (ceinture vert) aproveitando trechos de florestas e a morfologia do território. $\mathrm{Na}$ área nova (nouvelle ville), permitiria a verticalização limitando a altura dos edifícios ao morro e ocultando a visão a partir do rio, consequentemente não interferindo no conjunto histórico. Também

\footnotetext{
146 A busca se deu nos arquivos do IPHAN do Rio de Janeiro, São Paulo e Paraná, mas não obtivemos êxito. Em contato com o arquiteto Limburg-Stirum, por email, o questionamos sobre o plano e ele nos disse que não possui o material: "Quant à Paranagua, Dr. Rodrigo m'avait chargé d'un avant-projet. Il doit se trouver dans les archives du DPHAN à Rio. Je n'ai rien avec moi." (LIMBURG-STIRUM, 2015).

147 A informação está contida no relatório elaborado pelo representante da Unesco, Michel Parent em seus levantamentos executados no Brasil à pedido do Iphan nos anos de 1966 e 1967. PARENT, Michel. Proteção e Valorização do Patrimônio Cultural Brasileiro no Âmbito do Desenvolvimento Turístico e Econômico. In: As Missões da Unesco no Brasil: Michel Parent. LEAL, Claudia Feierabend Baeta (Org). Rio de Janeiro: Iphan, COPEDOC, 2008. Segundo Márcia Sant'Anna (1995, p.153): "Parent percorre quase o Brasil inteiro em duas viagens, entre 1966 e 1967. A partir delas elabora um relatório que passa a constituir base de toda a atuação futura não só do SPHAN mas de todo o governo federal com relação ao patrimônio: sua preservação através do planejamento urbano e do aproveitamento turístico."

148 São escassas as informações sobre a chácara do Caju, sabe-se apenas que foi demolida para dar lugar a um hotel.
} 
determinou a implantação de uma zona de construções de baixo gabarito, mais próxima ao centro histórico (quartier historique), em que as duas áreas seriam interligadas por vias, carros e caminhões, proibidos de circular na área antiga.

Assim percebemos que em ambas as propostas, tanto em Paranaguá, quanto em Paraty, o grande mote está em estabelecer as visuais do conjunto histórico a partir da visão pela extensão das águas, soluções adotadas pela pertinência do território. Tanto em Paranaguá, quanto em Paraty, as áreas verticalizadas, ou estão afastadas do rio, no caso paranaense, ou implantadas atrás dos morros, no caso fluminense.

Dessa maneira, ao percorrer os meandros administrativos do IPHAN, pudemos desvendar o processo que dá sustentação à afirmação que está na proposta de delimitação do centro histórico de Paranaguá de 1967, que integra o Plano Diretor de Paranaguá (PARANÁ, 1967): "foi feito levando em conta estudo elaborado pelo arquiteto Frederic de Limburg-Stirum, em seu trabalho Notes pour elaboration d'un Plan d'Urbanisme de Paranaguá." Sem dúvida, Limburg-Stirum é o grande mentor da definição do primeiro perímetro do centro histórico de Paranaguá e, quando questionado sobre quais bases teóricas se fundamentou para elaborar os dois planos, de Paraty e Paranaguá, afirmou que foi o plano do General Louis-Hubert Gonzalve Lyautey (1854-1934) para a cidade de Fés.

Conforme Charlotte Jelidi (2010), a ligação de Lyautey com os planos urbanísticos tomou grande proporção quando assumiu o cargo de General Residente do Marrocos, a partir do estabelecimento do Protetorado Francês. O general, durante seus 13 anos de governo, teve por marca a criação e expansão das cidades marroquinas inseridas numa política de governo em que o planejamento urbano era uma das prioridades. (JELIDI, 2010). O envolvimento de Lyautey com o patrimônio histórico marroquino se deve ao seu interesse pela temática e ao estabelecer o Serviço de Estética Urbana e de Conservação de Monumentos Históricos sob a tutela do escritório do General Residente, ou seja, nos domínios 
de Lyautey $^{149}$. Sua proposta para Fés, ainda na década de 1910, teve como grande colaborador, o urbanista Jean Claude Nicolas Forestier (1861-1930), e posteriormente Henri Prost (1874-1959) que elaboraram o plano para a nova Fés (nouvelle-Fès) separada da Medina (Figura 53), pela área denominada non aedificandi (Figura 53). De acordo com Charlotte Jelidi (2010, p.93):

Les projets de toutes les villes nouvelles du Maroc imaginés par Forestier puis Henri Prost reposent donc sur un même schéma : création d'une ville nouvelle à côté, mais en dehors de la ville ancienne, dont elle est séparée par une zone non aedificandi.

Figura 53: Fotografia de Fez em 1917, as muralhas de proteção da Medina e o cinturão verde proteção para o crescimento urbano. Fonte: Fotografia do Comandante Larribe, 1917

http://darbalmira.com/ historic-fes/

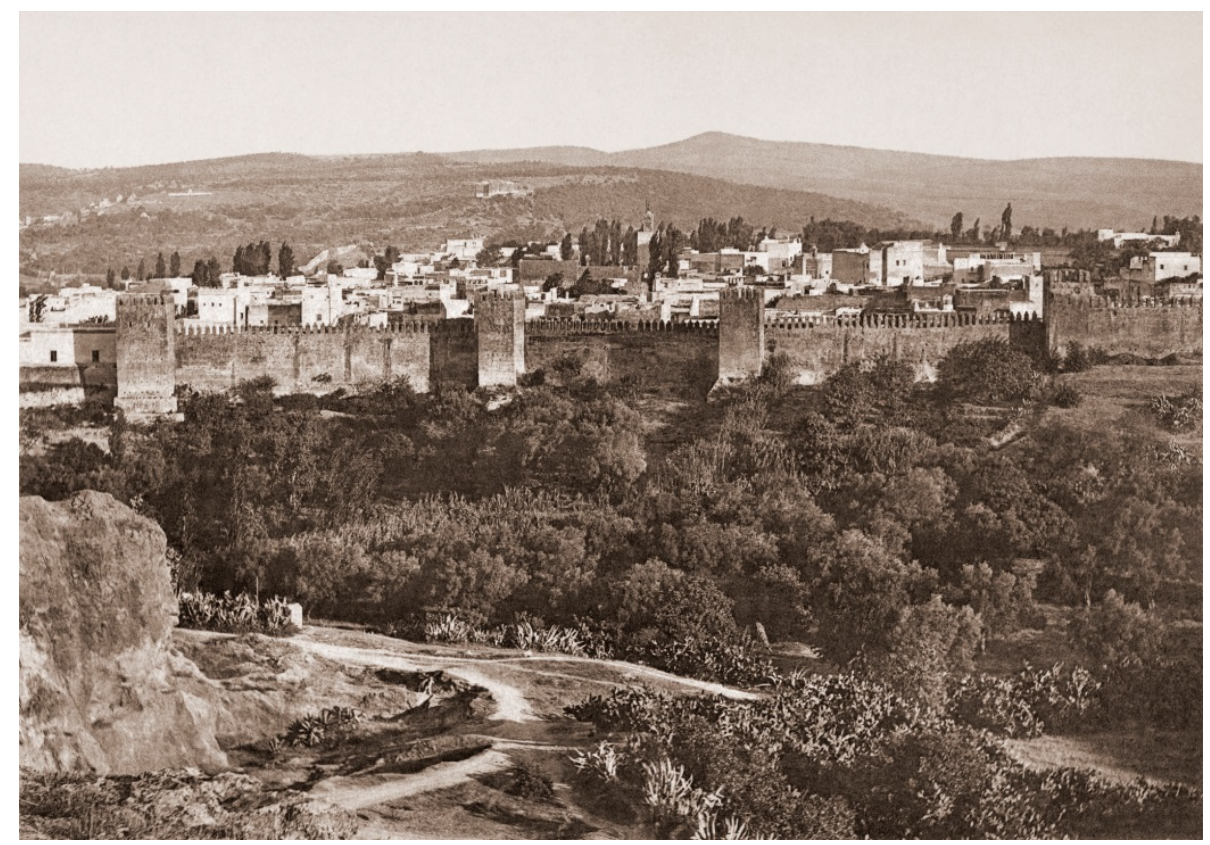

A zona non aedificandi em Fés refere-se ao espaço entre as muralhas da Medina e as áreas da nova cidade, uma área de amortecimento, não permitindo construções. Estes espaços são predominantemente constituídos de áreas verdes e a ligação entre as duas áreas se dá pelas estradas e vias férreas, este distanciamento permitiu que a cidade murada não fosse atingida pelo crescimento urbano, a proposta de Lyautey é peculiar, pois respeitou uma tradição de ocupação urbana que são os bairros muçulmanos em contraponto com a nova cidade de características ocidentais, pois:

\footnotetext{
149 Segundo Jelidi (2010) o Serviço de Estética Urbana e de Conservação de Monumentos Históricos Marroquinos, iniciou estudos sobre monumentos e obras de arte do Marrocos partindo do critério de qualidades artísticas e interesse histórico com o propósito da conservação do "pitoresco nativo".
} 
Ao contrário da política adotada na Argélia, a modernização do Marrocos respeita as fundações urbanas tradicionais, e criam-se cidades que seguem os novos critérios técnicos ocidentais. Essa opção traduz a vontade de preservar, com seu suporte espacial original, modos de vida e uma visão do mundo diferentes e considerados incompatíveis com a urbanização de tipo ocidental. Mas a apreciação estética faz parte, secundariamente, dessa vontade de conservação e talvez ela própria a integre numa prospectiva do turismo de arte. (CHOAY, 2001, p.193).

A proposta de Limburg-Stirum e o Plano de Paranaguá de Cyro Corrêa Lyra são contemporâneos ao período marcado pelas propostas de planos promovidos pela UNESCO em outras cidades históricas brasileiras, Paraty (1968), Ouro Preto (1969) e Salvador (1968) ${ }^{150}$. Também se refere à gestão de Renato Soeiro na diretoria do IPHAN, em que "[...] foram dados os passos definitivos e fundamentais para a modernização do aparelho estatal de preservação do patrimônio, assim como viabilizados os meios financeiros e materiais para a deflagração desse processo" (SANT’ANNA, p. 155, 1995). No Paraná, a ativa participação da Secretaria de Cultura, como vimos anteriormente no caso das igrejas, e as condições favoráveis no que tange ao planejamento urbano na gestão Ney Braga (1961-1965) e posteriormente na gestão Paulo Pimentel (1966-1971), permitiram a elaboração do plano diretor de Paranaguá e a delimitação do centro histórico articulando com diversas frentes de análise pois não competia apenas à delimitação do centro histórico, mas de toda a cidade contando com economia, população, educação, transportes etc., acabando por se constituir numa das primeiras experiências deste porte elaboradas no Brasil. ${ }^{151}$

E foi nesse contexto que ocorreu a elaboração do plano de Paranaguá. A proposta surgiu durante um curso de planejamento urbano promovido pela CODEPAR $^{152}$ (Coordenação de Desenvolvimento do Paraná), criada em 1962, na

\footnotetext{
150 Para Paraty, o plano de Limburg-Stirum; em Ouro Preto por Viana de Lima, intitulado Rénovation et mise em valeur d' Ouro Preto: Brésil; e em Salvador o plano de Graeme Shankland e David Walton intitulado São Salvador de Todos os Santos: Town Planning Conservation and Tourism.

151 A proteção de centros históricos no Brasil se relaciona com a política desenvolvimentista brasileira nas décadas e 1950/1960 que atingiu cidades antigas a partir do crescimento demográfico, metropolização e industrialização, consequentemente a abertura de novas rodovias causou sérios impactos às cidades históricas. (TELLES, 1984)

152 A CODEPAR foi criada num momento em que era necessário estabelecer bases para a industrialização e desenvolvimento do Paraná. A Companhia administrava um fundo obtido de imposto sobre vendas e consignações realizadas no Paraná e atuava em diversas áreas ligadas à infraestrutura. Também financiava a elaboração de planos
} 
gestão do governador Ney Braga, e contou com a presença de arquitetos, historiadores e economistas. Cyro Corrêa Lyra, um dos alunos do curso, foi convidado para coordenar o grupo multidisciplinar que elaboraria o Plano Diretor de Paranaguá e, por ter afinidade com o tema do patrimônio histórico, foi incluído na proposta, conforme nos relatou em entrevista (LYRA, 2012):

Então nós ficamos durante um tempo fazendo o plano diretor de Paranaguá. Como eu era muito marcado por essa questão da [...] era o único que tinha conhecimento dessa questão da preservação, eu entrei com essa vertente de preservar o centro histórico de Paranaguá, que era um centro histórico muito empobrecido. Porque Paranaguá, como ocorreu em todas as cidades litorâneas, perdem interesse da classe média alta durante o século XX, porque passam a residir, e tem mais interesse, nos lugares voltados pro mar. Então, durante, principalmente, talvez, a partir dos anos 40, se desenvolve os balneários paranaenses, Matinhos, Caiobá, Guaratuba, e essas pessoas saem de Paranaguá, as pessoas de classe alta, inclusive porque Paranaguá está empobrecida. Paranaguá nos anos 60 vive em função do porto, o porto tem um desenvolvimento enorme, uma grande exportação a cidade está cheia de gente ligada ao porto, e aquela classe, que vivia naquelas casas do centro, saem dali e há muitos sobrados ricos, muito bons, que passam a ser ocupados por comerciantes que vem de outros lugares e que não tem nenhuma relação com a cidade.

De um modo geral, a implementação do turismo é destacada no Plano Diretor de Paranaguá, já que parte das iniciativas para a preservação apontadas no estudo tem como um dos objetivos principais estabelecer metas para o desenvolvimento turístico, como alternativa de recuperação econômica para o município. De acordo com o plano,

A cidade de Paranaguá é o núcleo colonial mais importante do Paraná: a parte antiga da cidade guarda ainda as características de cidade colonial, além de conservar alguns monumentos históricos importantes.

A cidade antiga se localiza junto à foz do rio Itiberê, compondo um conjunto de paisagem urbana com paisagem natural que dá a Paranaguá grandes possibilidades de se tornar uma cidade turística. (PARANÁ, 1967, p. 91)

Convém lembrar a importante contribuição de Michel Parent frente às cidades históricas brasileiras, uma vez que, no relatório de sua autoria intitulado La 
protection et mise en valeur du patrimoine culturel brésilien dans le cadre du developpement touristique et économique de 1968, consta, além de sua análise das cidades visitadas, como Ouro Preto, Salvador, São Luís etc., sugestões sobre a necessidade de utilização turística dos monumentos como alternativa para obtenção de recursos e, consequentemente, viabilizar sua manutenção.

Este tema, a viabilidade econômica dos projetos de preservação a partir do turismo, também estava entre as principais discussões do II Encontro dos Governadores. O primeiro encontro já havia acontecido em Brasília, em 1970, durante a administração de Renato Soeiro no IPHAN e, de acordo com ele, o encontro buscava debater, "os problemas relacionados com a defesa e a preservação dos nossos bens de valor cultural [...]" (BRASIL, 1973). Dessa primeira discussão resultou a Carta de Brasília. O segundo encontro ocorreu logo em seguida, de 25 a 29 de outubro de 1971, e permitiu dar continuidade às discussões sobre o patrimônio brasileiro que resultaram no Compromisso de Salvador.

Dos temas discutidos no II Encontro, vale salientar o forte enfoque dado ao turismo das cidades históricas, sua divulgação nos meios de comunicação, a preparação dessas cidades para atender às exigências decorrentes do turismo, a criação de roteiros turísticos nacionais e o uso de monumentos para o turismo e atividades culturais. Os representantes do Paraná neste encontro foram: Newton Carneiro, Haroldo Souto Carvalhido, Igor Chmyz, Dalena Guimarães Alves e Cyro Corrêa Lyra.

É digno de louvor o nível das discussões empreendidas durante o Encontro, permeando o tema do turismo com as teorias de restauração. Em um dos discursos, Wladimir Alves de Souza (1908-1994) ${ }^{153}$, representante do Rio de Janeiro, destaca que:

O valor do patrimônio cultural reside na sua autenticidade, e a técnica da restauração de monumentos é um caminho semeado de espinhos. É necessário resistir à tentação da reconstrução total, a fim de restabelecer o monumento, não apenas como teria sido, mas como "deveria" ter sido.

153 Arquiteto carioca esteve envolvido em projetos de restauração em vários Estados brasileiros. 
Censurado severamente pelos críticos de hoje, Viollet-le-Duc exagerou, com efeito, a extensão de certas restaurações, como a do castelo de Pierrefonds, mas é justo atribuir-lhe o mérito de trabalhos notáveis, como a restauração da Madeleine de Vézelay, ou mesmo da nova flecha de Notre Dame de Paris, tão bem incorporada ao conjunto da catedral. Não é, entretanto, objetivo do presente trabalho entrar no mérito da técnica de restauro, senão assinalar o turismo como fator de reanimação dos bens culturais. Mas não é possível omitir a importância da "qualidade" no trabalho de restauro. (BRASIL,1973, p. 279-280).

Ou seja, apesar das discussões contemporâneas sobre restauração empreendidas principalmente na Itália e após quase dez anos da divulgação da Carta de Veneza, ainda persistia uma apreensão com relação aos procedimentos de restauro nos moldes leducianos.

Quanto ao Plano Diretor de Paranaguá, o local com maiores potencialidades turísticas é, sem dúvida, a rua General Carneiro. Esta via, margeada pelo rio Itiberê possui um conjunto de sobrados de diversos períodos, sendo predominantes aqueles do século XIX. Assim, a proposta de Cyro Corrêa Lyra teria por objetivo dar destaque e valorizar esta via. A região ribeirinha, nos anos de 1960, estava em abandono motivado principalmente pela transferência total das atividades portuárias para o novo porto de Paranaguá. Existia um depósito de lixo defronte ao antigo Colégio dos Jesuítas e também já eram perceptíveis os problemas de assoreamento do rio, principalmente na área próxima ao Museu de Arqueologia. Cyro propôs que fosse criada uma via turística, “[...] como via de ligação a acessos em todos os pontos turísticos: o próprio Centro Histórico, com seus monumentos

Figura 54). O Porto, o parque da Costeira; os clubes Olímpicos e Yate; a zona de pesca e o cais do "bateau-mouche". (PARANÁ, 1967, p. 161). Havia também a ideia de limitar a circulação de veículos pelo centro histórico, bloqueando algumas ruas e permitindo apenas a circulação de pedestres, que seriam aquelas 
perpendiculares ao rio Itiberê e a rua Conselheiro Sinimbú, acesso principal ao conjunto.

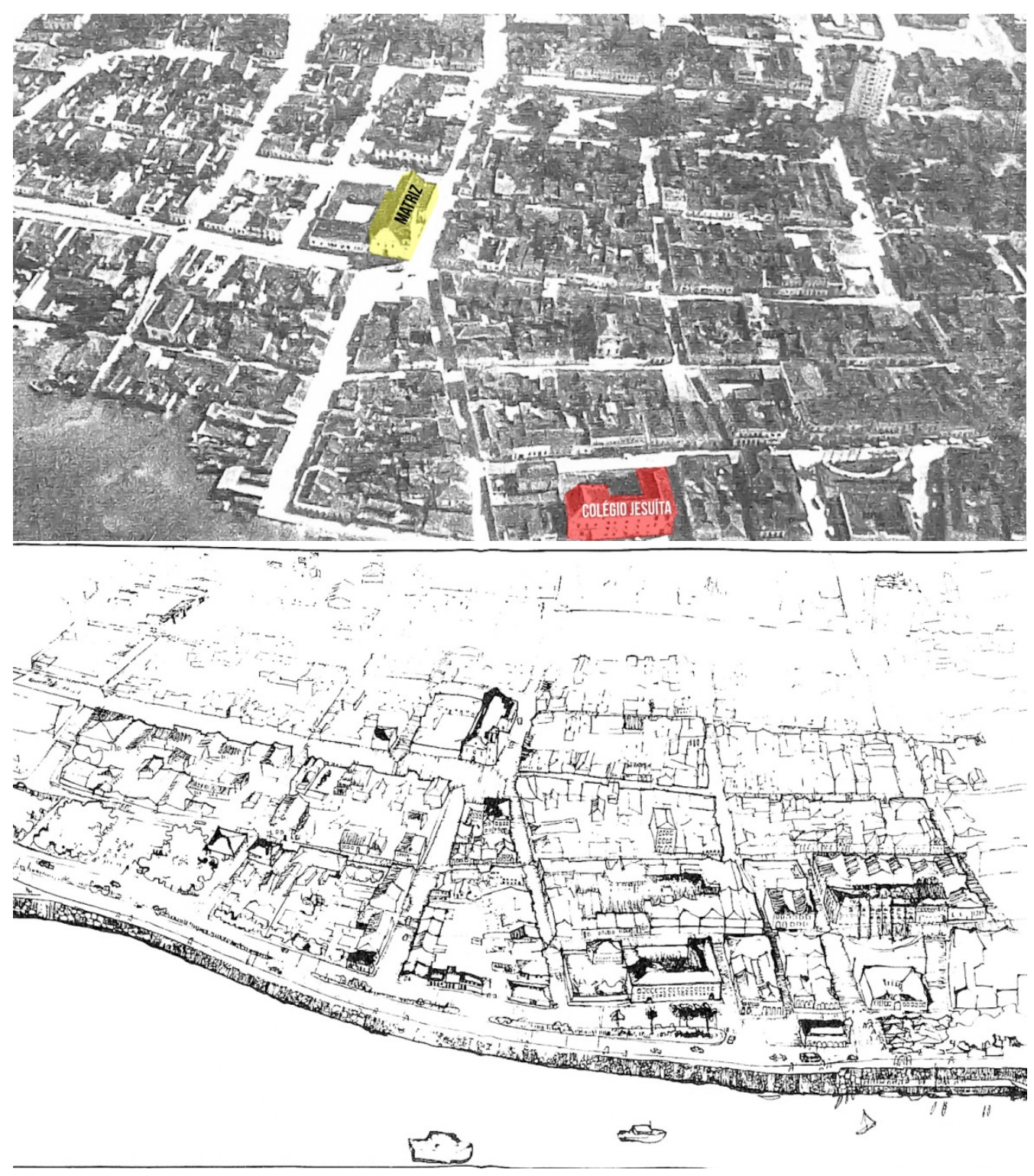

Figura 54: As duas imagens, do Plano de 1968 , apresentam a situação encontrada nas margens do Rio Itiberê, na altura do Colégio Jesuíta e abaixo a proposta da via turística na área ribeirinha.

Fonte: PARANÁ, 1968, adaptado pelo autor, 2015.

A delimitação proposta por Cyro Corrêa Lyra para o centro histórico envolveu as principais edificações já listadas nas notas de Limburg-Stirum, a Ponta do Caju, a Fonte da Gambôa, a Igreja São Benedito e a da Ordem Terceira, a Matriz, o casario defronte à Matriz, o sobrado do Visconde de Nácar, o conjunto da Rua da Praia e o Colégio dos Jesuítas (Figura 55). Foi a maneira de fortalecer as medidas relativas à ambiência dos monumentos que já possuíam tombamento federal, leia-se Colégio Jesuíta, Igreja da Ordem e São Benedito. Ou seja, a 
delimitação da área histórica excluiu edifícios como a Estação Ferroviária, a Escola Normal e outros do século XIX. O porto foi citado não apenas por sua importância econômica, mas como destino turístico, item que também foi considerado na proposta de Limburg-Stirum. O arquiteto belga havia sugerido que os antigos espaços portuários fossem preservados, provavelmente aqueles construídos no século XIX, e que as novas atividades fossem organizadas no que ele denominou Usinas de Transformaşão, integrando o serviço de transporte com o setor industrial e criando espaços de turismo e lazer nas áreas portuárias.

Assim, o Plano Diretor de Paranaguá foi instituído pela Lei no 773 de 12 de setembro de 1969 e nos anos 1970 já eram percebidos seus efeitos, principalmente no que tange ao turismo. Em 1974, a Embratur classificou Paranaguá como cidade histórica, incluindo-a nos roteiros turísticos no Sul do Brasi ${ }^{154}$. Uma revista de circulação estadual, Paraná em Páginas, teve como tema, em julho de 1975, a cidade de Paranaguá associando-a ao turismo e às atividades portuárias. As matérias e as campanhas publicitárias retratam, como imagem da cidade, o porto e a Rua da Praia

Figura 57). Quanto aos itens que se referem à circulação, muito pouco foi implantado, a ideia de reduzir o trânsito de automóveis não foi aplicada, mas outros itens, como a manutenção da escala do centro histórico ainda permanece nos dias de hoje, apesar da construção de alguns edifícios de maior altura (Figura 56). O Plano estabeleceu também a criação do Escritório Técnico de Planejamento (ETEPLAN), exigindo que o coordenador fosse engenheiro civil ou arquiteto e que teria por responsabilidade a elaboração, coordenação e controle do Plano. O centro histórico de Paranaguá é denominado Zona Comercial I, sendo a“Área que corresponde ao atual centro histórico, onde as construções de caráter histórico determinam um gabarito reduzido para as novas construções e cuja densidade de ocupação deverá permanecer inalterada.” (PARANAGUÁ, 1969, p. 8).

\footnotetext{
154 Paranaguá foi destaque em reportagem do Jornal do Brasil de 31 de outubro de 1974, com o título: "Paranaguá, um porto colonial."
} 


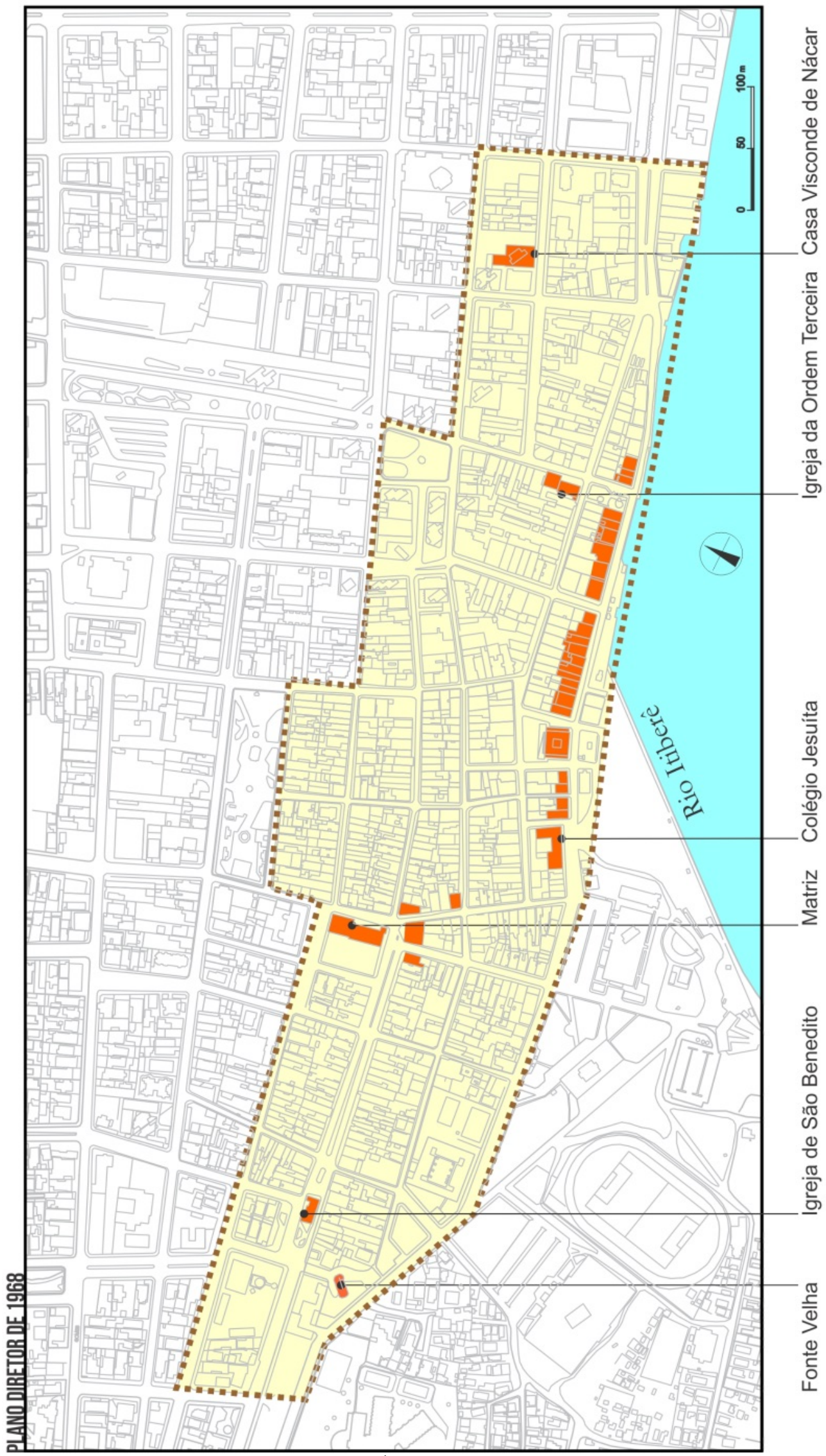

Figura 55: Delimitação do centro histórico proposta por Cyro Corrêa Lyra para o Plano Diretor de Paranaguá. Fonte: PARANAGUÁ, 1968. 


\section{PARANAGUÁ: IDENTIDADE E PRESERVAÇÃO}

Figura 56: Apesar de manter a escala urbana, Paranaguá sofreu com a construção de alguns edifícios desproporcionais ao contexto urbano. Fonte: Acervo do autor, 2013.

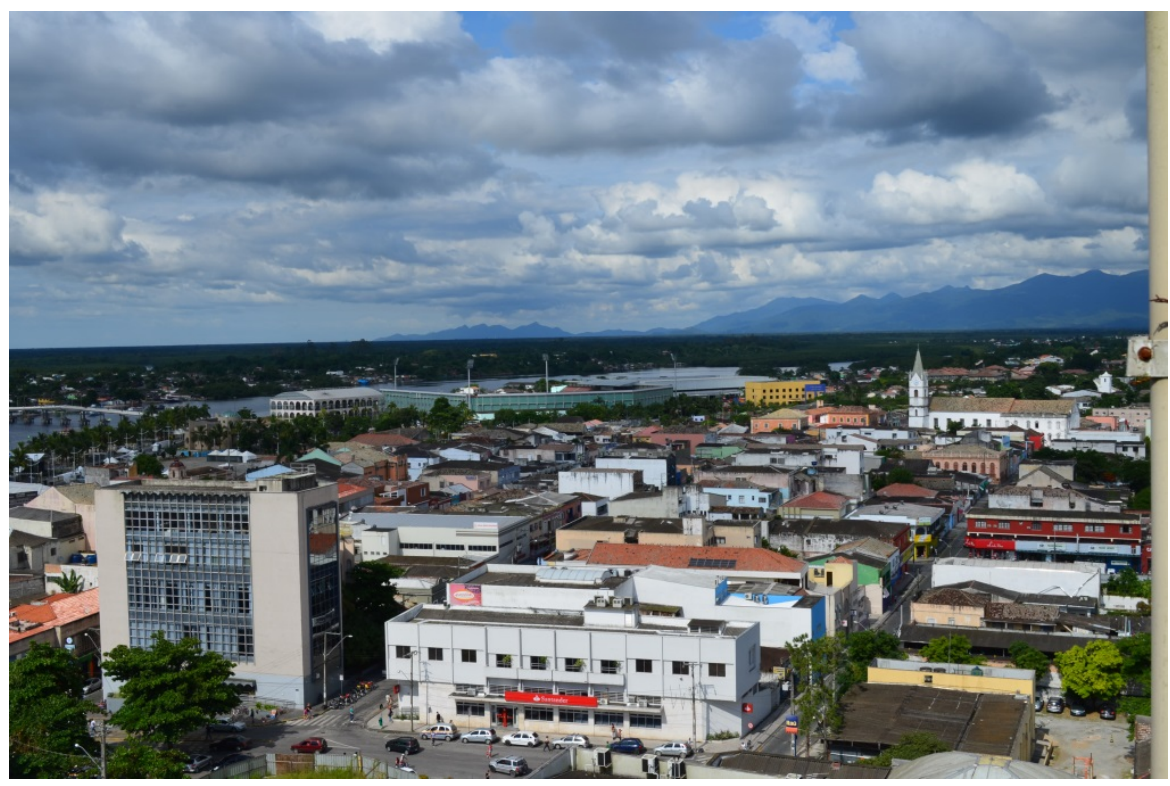

Figura 57: Uma das publicidades de Paranaguá que retratam a Rua General Carneiro, também conhecida por Rua da Praia. Fonte: Revista Paraná em Páginas.
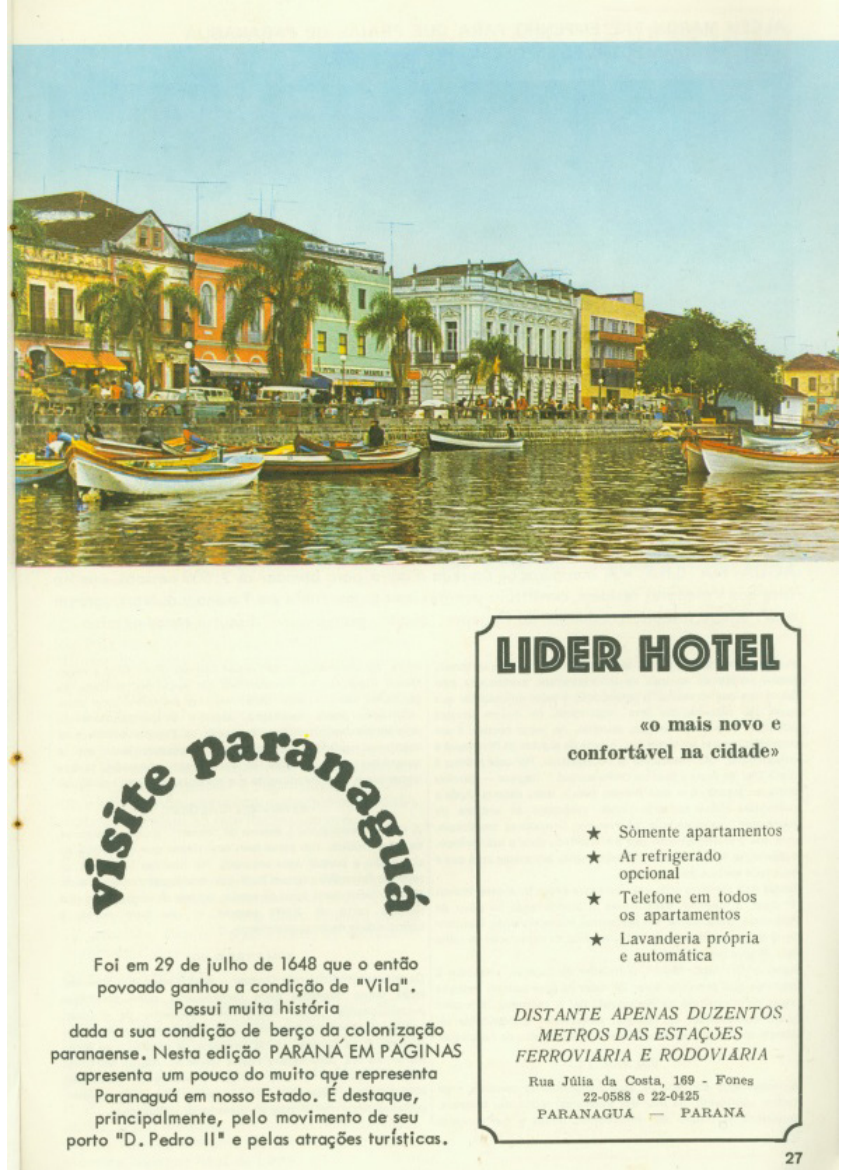

Desse modo, vemos que o pioneirismo no Plano Diretor de Paranaguá está diretamente relacionado às influências das missões estrangeiras a partir do acordo entre UNESCO e IPHAN nos anos de 1960. E o grande mérito do plano de Paranaguá está em permitir uma análise não restrita apenas ao centro histórico, mas 
compreendendo toda a área urbana de uma cidade em crescimento e com forte tradição nas atividades portuárias. Portanto, Paranaguá tem assinalada a sua contribuição ao planejamento urbano em cidades históricas, motivada pela favorável situação no âmbito estadual e particularmente nas figuras de Rodrigo Melo Franco, Cyro Corrêa Lyra e Dalena Guimarães Alves, que possibilitaram as condições para que o Plano Diretor 1968 se efetivasse. 


\subsection{PARANAGUÁ: CIDADE PATRIMÔNIO}

A partir do estudo elaborado por Frederic de Limburg-Stirum e o Plano Diretor de Paranaguá de 1968 de autoria de Cyro Corrêa Lyra que houve a compreensão da cidade como conjunto histórico. Estes estudos se refletiram em iniciativas posteriores de proteção e contribuíram décadas mais tarde para o tombamento federal. Portanto para compreendermos estes processos é necessário analisarmos o ambiente político e administrativo que perpassa as atividades que marcaram a preservação de Paranaguá. De acordo com José Reginaldo Gonçalves, os anos de 1970 são um marco nas políticas de preservação no Brasil. Diz isso referindo-se à criação do Programa de Cidades Históricas (PCH), à ampla reforma administrativa do IPHAN e à nova mudança na direção da instituição com a entrada de Aloísio Magalhães (1927-1982). Aloísio foi coordenador geral do Centro Nacional de Referências Culturais (CNRC) e no ano de 1979 substituiu Renato Soeiro na direção do IPHAN. O Centro Nacional de Referências Culturais havia sido criado em 1975, com o objetivo de estabelecer parâmetros para a descrição e análise da dinâmica cultural brasileira, estes parâmetros baseavam-se em quatro áreas principais: Artesanato, Levantamentos Sócio-Culturais, História da Tecnologia e da Ciência no Brasil e Levantamentos de Documentação sobre o Brasil. Segundo Cecília Londres (2009, p.145):

\footnotetext{
Os projetos desenvolvidos pelo CNRC punham entre parênteses modelos de interpretação já prontos, inclusive os quadros conceituais das diferentes disciplinas, e procuravam, através de uma perspectiva interdisciplinar, apreender a dinâmica específica de cada processo cultural estudado, formulando, a posteriori, tipologias e modelos.
}

O CNRC foi um grande passo para o desenvolvimento de pesquisas e levantamentos sobre a "cultura popular" com o intuito de transformá-las em produtos industriais, a partir da mescla da tecnologia e do saber fazer artesanal. 
(LONDRES, 2000). A exclusividade dos arquitetos frente à proteção do patrimônio começa a reduzir e a gestão de Aloísio Magalhaes estava direcionada para a ampliação dos conceitos não apenas voltados ao patrimônio arquitetônico, mas também na sua relação com as mais variadas expressões culturais:

No discurso de Aloísio, categorias como "povo", "segmentos sociais", "comunidades" e outras são usadas para objetificar a sociedade brasileira enquanto uma entidade plural. São elas os protagonistas de sua narrativa. A nação é visualizada não de modo monumentalista, mas como uma pluralidade de grupos sociais, segmentos, comunidades e suas respectivas culturas, compondo um quadro marcado pela heterogeneidade." (GONÇALVES, 1996, p.87).

É neste momento que modalidades de tombamentos, antes nunca previstas pelo Serviço do Patrimônio, foram aplicadas em casos peculiares. Há o importante exemplo do Terreiro Casa Branca do Engenho, registrado em 1984, foi a primeira iniciativa do gênero na história da instituição e tornou-se alvo de intensas discussões pelos técnicos e conselheiros do IPHAN. Tendo como relator do processo o Professor Gilberto Velho, tinha por principal argumento a base jurídica do Decreto-lei $n^{\circ} 25$ que apontava para a proteção dos bens materiais e imateriais ${ }^{155}$. Este é um exemplo claro das mudanças desencadeadas por Aloísio Magalhães, mas também devemos considerar a abertura já iniciada na gestão de Renato Soeiro. Em São Paulo, o CONDEPHAAT também empreendeu ações de tombamento daqueles elementos de referência popular como terreiros de Candomblé e Quilombos, apesar de ainda manter-se apegado a certos padrões pré-estabelecidos:

[...] até hoje, estes bens apresentam-se como uma exceção em um universo em que predomina uma visão monolítica de passado e de memória oficial, na qual os sujeitos representados estão ligados às elites política, econômica, religiosa e militar. Sujeitos sociais como os trabalhadores, sejam eles os antigos escravos ou operários e camponeses, não estão devidamente contemplados neste conjunto. Isso apesar dos avanços na própria base legal, estabelecidos pela Constituição Federal de 1988, que desvinculou necessariamente o patrimônio dos valores

\footnotetext{
155 Sobre o Terreiro da Casa Branca do Engenho Velho há uma interessante análise de Odete Dourado no artigo: Antigas falas, novas aparências: o tombamento do Ilê Axé Nassô Oká e a preservação dos bens patrimoniais no Brasil. Publicado na revista Risco de 2011.
} 
estético-estilístico ou arquitetônico, a partir do momento em que o definiu como relativo àqueles bens portadores de referência à identidade, ação e memória de diferentes grupos sociais. (SCIFONI, 2013, p.127).

Outra importante política de fomento ao patrimônio se deu na criação do PCH e foi uma alternativa de desenvolvimento dos Estados do Nordeste, a partir do entendimento por parte do IPHAN de se relevante conjunto de monumentos, tendo por base econômica o turismo. Foram reflexos dos convênios entre o IPHAN e a UNESCO e do Encontro dos Governadores:

O PCH possibilitou a montagem de um sistema nacional de proteção que só deixou de funcionar com o fim do programa. Esse sistema propiciou a democratização do patrimônio, tornando-o uma questão não exclusiva do poder público federal, assim como a descentralização da política de preservação, com a criação de entidades estaduais. Propiciou ainda a criação de rubricas financeiras para o patrimônio e a formação de novos quadros técnicos. (SANT'ANNA, 1995, p. 185)

O PCH, CNRC e IPHAN foram fundidos na Fundação Pró-memória em 1980 e resultou em drásticas mudanças nos quadros de técnicos. Antes majoritariamente arquitetos, agora incluem-se historiadores, sociólogos, antropólogos e economistas, apesar de que ainda presos às tradições da instituição. O corpo técnico formado naquele momento e o seu posicionamento frente à preservação do patrimônio - tradicionais de um lado e os que trabalhavam em consonância com o CNRC de outro, criaram distintas linhas de orientação. (SANT'ANNA, 1995).

Foi ainda nos anos de 1970 que se instalou em Paranaguá o primeiro técnico residente do IPHAN, José La Pastina, arquiteto, ex-aluno e sócio de Cyro Correa Lyra no escritório Aresta ${ }^{156}$. La Pastina entrou para a instituição no concurso de 
1978, ficando inicialmente em São Paulo e, a partir da ideia de Luís Saia, iniciou seus trabalhos em Paranaguá:

[...] aí em 78 ocorreu o concurso, o tão famigerado concurso do Iphan e nessa época, antes disso o Saia falava: não, La Pastina você vai fazer o concurso do Iphan, dai a empresa você passa pra alguém e você vai morar lá em Paranaguá, o Museu de Paranaguá vai ser o museu cabeca do sistema de museus. Ele pensava num sistema, o Saia tinha essa capacidade de pensar tudo em termos integrados. Não, vai ter um grande museu de arqueologia do sul do país, outro no norte, nordeste, então do Espírito Santo para cá o museu cabeça seria este museu e você vai morar lá. Por essa razão em 1976 eu fui morar em Paranaguá. A minha mulher, médica formada, tinha acabado a especialização dela, se associou com outros médicos com especialização e titulação e criaram um centro médico especializado na cidade que não tinha e depois a gente acabou virando acionista do hospital, porque o hospital também precisava, estava em construção e precisava de técnicos capacitados. Enfim, então, eu morei em Paranaguá de 1976 até o final dos anos 80 e nesse tempo a gente fez várias obras lá em Paranaguá, Colégio Jesuíta, igreja de São Francisco, a igreja de São Benedito. (LA PASTINA, 2012).

Foi na gestão de Renato Soeiro, que a atuação do IPHAN nos Estados se ampliou. ${ }^{157}$ Dos quatro Distritos existentes desde 1946, foram transformados em nove Diretorias Regionais em 1976, sendo que as sedes e suas jurisdições eram: Belém (Pará, Amazonas, Acre, Amapá e Roraima); São Luís (Maranhão, Piauí e Ceará); Recife (Pernambuco, Paraíba, Alagoas e Rio Grande do Norte e Fernando de Noronha); Salvador (Bahia e Sergipe); Rio de Janeiro (Rio de Janeiro e Espírito Santo); Goiás (Goiás, Mato Grosso, Rondônia e Distrito Federal); São Paulo (São Paulo e Paraná); Porto Alegre (Rio Grande do Sul e Santa Catarina) ${ }^{158}$ (Figura 58). Segundo Renato Soeiro (1977, p.9):

\footnotetext{
157 Apesar das críticas que colocam a gestão de Renato Soeiro, frente ao IPHAN, considerando uma fase de transição entre Rodrigo Melo Franco e Aloísio Magalhães e apontando a falta de autonomia desta gestão, de acordo com Maria Cecília Londres (2009), Renato Soeiro teve importante contribuição, principalmente na criação dos escritórios técnicos que permitiu a descentralização e a oportunidade de aproximação entre o IPHAN e aqueles Estados subordinados as Diretorias Regionais, portanto consideramos como o início de uma nova fase da instituição, que foi continuada e ampliada por Aloísio Magalhães.

${ }^{158}$ Dados obtidos na Revista C.J. Arquitetura, Ano V nº17, a edição foi alusiva aos 40 anos do IPHAN.
} 
Acredito que esse desdobramento vai atender melhor os Estados, porque aqueles que não são sede de Diretoria Regional terão uma representação do Patrimônio. Uma área maior do território nacional será dessa forma coberta pela ação do IPHAN, preservando os bens culturais de maneira mais efetiva.

Figura 58: A formação dos oito distritos na gestão de Renato Soeiro.

Fonte: Acervo do autor, 2015.

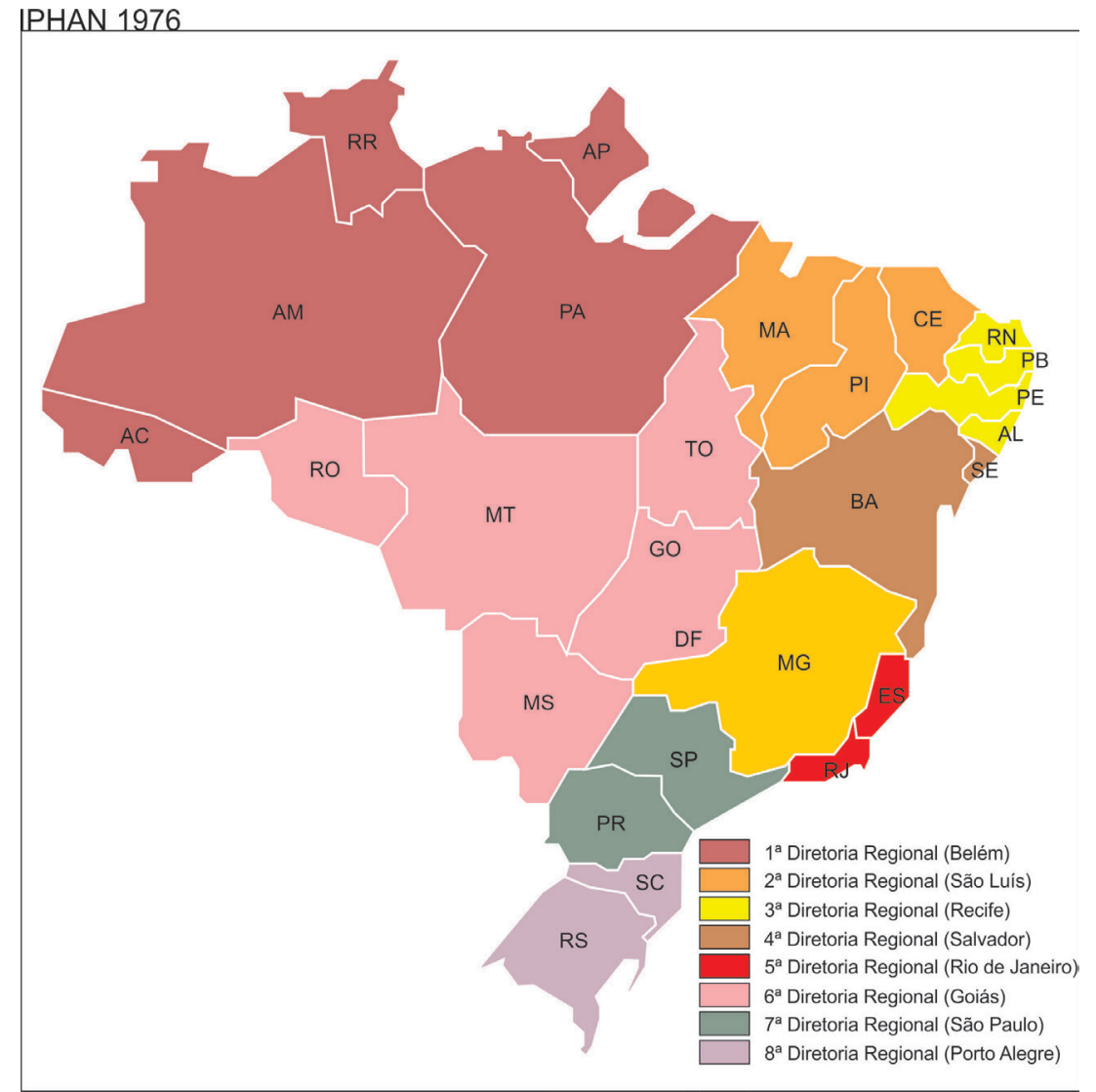

A ideia de descentralização já rondava as conversas entre os técnicos do IPHAN desde os anos de 1960, como poderemos ver no caso da restauração da igreja de São Benedito, em que em seu relatório sobre as obras, Cyro comentou:

Com o objetivo de preservar o acervo artístico da cidade, a Divisão do Patrimônio Histórico e Artístico do Estado do Paraná, tomou a iniciativa de restaurá-la. Essa experiência se reveste de grande importância, porque abre perspectivas de iniciativas semelhantes, por parte dos Governos estaduais, de preservação do patrimônio artístico dos seus estados. Isso possibilitaria o desafogo do DPHAN, sobrecarregado com a tarefa de preservar todo o Patrimônio Histórico e Artístico no Brasil. (LYRA, 1965, p.01). 
A centralidade, tão presente na administração de Rodrigo Melo Franco frente às decisões sobre o patrimônio nacional, começou a ser posta em cheque. Havia o aumento da demanda para atender a obras de restauração, o que consequentemente, ampliava o trabalho dos técnicos, uma vez que a atuação não se restringia apenas aos bens tombados pela instância federal, mas também ao acompanhamento técnico naqueles bens em que havia o interesse dos órgãos estaduais e municipais na sua preservação. Estes dados nos fazem acreditar que, provavelmente, a alta demanda pelas restaurações e acompanhamento técnico foi uma das condicionantes para a criação das nove diretorias regionais e também dos escritórios técnicos.

No caso da sede do Escritório Técnico do Paraná, ao analisar a documentação encontrada e na entrevista com o arquiteto José La Pastina, percebemos que existia um impasse entre o Paraná e São Paulo provocado pelo desinteresse e possível receio da instituição paulista, agora administrada por Antônio Luiz Dias de Andrade, frente à criação de uma sede própria para o escritório no Paraná, é visível que a tomada de decisões sobre as solicitações paranaenses eram solucionadas pelos técnicos no Rio de Janeiro. A necessidade da instalação de Escritórios Técnicos nos Estados, em que não existiam diretorias, foi uma das exigências da recém-criada Fundação Nacional Pró-Memória. Dessa maneira, José La Pastina, que já estava instalado numa sala da Secretaria de Estado da Cultura, em Curitiba, teve a inciativa de criar uma sede para o escritório em outro local. Mas, o desinteresse demonstrado pela Direção paulistana frente às ideias de La Pastina, foi prejudicial para sua concretização, e que nos revela os problemas existentes na relação entre as respectivas instâncias. Este desinteresse tornou-se mais explícito quando houve a possibilidade de instalação de um novo escritório em Curitiba. Este caso foi relatado em entrevista por José La Pastina (2012):

Olha, com a Regional, Superintendência à qual o então Escritório Técnico estava submetido, as relações eram formais, mas muito 
prejudicadas porque o Paraná era muito deixado de lado. Então, tudo era uma batalha, tudo era difícil, esta própria casa aqui, pra sede do IPHAN, eu fiz um esforço muito grande pra conseguir viabilizar. Para montar o então Escritório Técnico do IPHAN no Paraná, eu precisava ter um local, aí eu consegui da Secretaria de Estado da Cultura um espaço no interior do prédio Estadual. Não, eu tenho o espaço não vai custar nada então vamos montar o escritório do patrimônio no Paraná. Só que eu nunca me conformei e nunca me conformaria de um órgão federal ficar dentro lá numa sala dentro do órgão estadual, isso pra mim era impensável. Eu conhecia esta casa aqui [atual sede do IPHAN], então, num processo de transição o escritório já tinha criado, e eu ia assumir lá dentro da secretaria. E essa casa foi colocada à venda, e eu entrei em contato com os proprietários, e acertei a compra. $\mathrm{Na}$ verdade eles iam doar primeiro, depois como a mãe deles não conseguia entender que como que a casa do pai dela havia construído ia ser doado. O que valia lá era o terreno, então tem um prédio de oito andares hoje lá, mas, enfim, a família fez um precinho simbólico e, através do Cyro Lyra que estava já no Rio de Janeiro nessa época, levou fotos da casa para o Irapuã Cavalcanti de Lyra, não são parentes mesmo. Ele falou: Olha tem essa casa, o La Pastina quer comprar, é interessante, é uma casa de madeira, mas o pessoal de São Paulo não quer, eles eram contra. Como que o Iphan compra a casa lá, mas eu não posso comprar num bairro afastado, uma fortuna, não dá, não tem sentido, porque que não tomba então a casa? Como vai tombar uma casa caindo aos pedaços né? Eu ia penalizar o proprietário dessa forma? Daí o Cyro convenceu o Irapuã da importância da casa e eu não tinha o terreno, eu era amigo do prefeito, que era o pai do atual prefeito, era o Maurício Fruet, eu era ligado ao partido e tal e eu: Não, eu consigo o terreno da prefeitura e aí eu havia recebido autorização e fui lá. Comprei. Aí começou o drama porque tinha um pessoal morando lá e a condição era assim até dezembro. Eu comprei, sei lá, em outubro, setembro, uma coisa assim, a família tinha que desocupar a casa e eu teria que desocupar o terreno. E aí eu não tinha nem o terreno. Para onde deslocá-la, né? E aí a família rapidamente conseguiu tirar o morador, aí eu fiquei com a casa vazia sujeita à tudo, várias vezes, final de semana, eu dormi lá pra cuidar da casa e um belo dia, eu fui lá, tinha um rapaz que debaixo da casa pegou uma bicicleta velha e um arado, que tá aqui na frente. Eu cheguei pro rapaz e disse: Olha como é que você tá pegando isso dai sem autorização? Não pois é meu trabalho. Ele era um coletor. Enfim, esse rapaz, eu acabei contratando pra guardião da casa sabe? E depois, quando a gente fez a obra, ele veio pra cá como guardião da casa e eu ensinei ele a fazer lambrequim. E esses lambrequins daqui, aqui eu concentrei os antigos [da fachada principal], os originais, e estes daqui são todos novos [lateral do edifício]. Esse rapaz que fez e eu ensinei ele. Eu tinha uma serra fita e aí eu ensinei como é que faz lambrequim, os balaústres, tudo foi ele que fez e depois ele pediu pra sair, achou emprego em outra empresa, mas era um cara que era um coletor. A Prefeitura cedeu estes três terrenos, fez a terraplanagem. Ele permitia um subsolo, então eu consegui fazer a cessão. Então eu vou contar rapidinho por quê. Primeiro, encontrar o terreno, então fui no cadastro da Prefeitura, encontrei esse terreno aqui, aí o pessoal falou: Olha pode doar, mas você vai ter que pegar a assinatura de todos os secretários municipais abrindo mão do terreno. E eu não sabia que 
passava um rio aqui. Então, eu fui lá, aí o que é que eu fiz, como urbanista e arquiteto, eu vou fazer um entorno aqui e vou plotar todos os equipamentos, escola, posto de saúde, hospital, clínicas, plotei tudo, jardins, praças e tal. Em cada secretário, eu ia e explicava, mostrava a foto da casa que ia ser desmontada e aqui tem tantas escolas em volta, daí o cara: Pô realmente! Aí assinava. Aí fui no secretário de saúde, daí era meu amigo, amigo de jogar futebol, tomar cerveja, mostrei e ele: Putz legal e tal. Aí cheguei no urbanismo, parques e praças, alguma coisa assim, eles olharam e aqui tava um matagal a vizinhança reclamando de rato, marginais que ficavam aqui aí falaram: Não, olha mais aí a gente poderia fazer uma grande praça aqui. Eu falei: Ai men Deus do céu. Não mas olha tem a praça lá em cima. E eles: Mas tem uma reivindicação. Daí tinha reclamação da vizinhança aqui sabe, era a chance de fazer isso e tal. E eu fiz uma proposta, eu deixo aberto e faço uma pequena praça aqui. Mas aquela pequena pracinha ali e aí conseguimos né. Aí porque a casa ficou nessa posição? Porque passa um rio canalizado, então eu tinha condição pra cessão do terreno, você tem que respeitar a legislação, os terrenos foram desapropriados porque, ao passar o rio, o município inviabilizou o uso para o proprietário, então é obrigado a desapropriar, pagar, se você conseguir usar respeitando os oito metros do eixo do rio, aí pode ser. Aí eu fui fazendo, eu tinha o levantamento da casa, deu certinho e ela ficou nessa posição. Por isso que ela está nessa posição. Isso de certa forma valoriza a casa porque ela era uma casa de esquina. Mostra que ela veio de um outro lugar. À noite, se você passar aqui à noite, você vai ver que eu fiz uma iluminação. Parece que ela pousou, porque tem uma iluminação que joga a luz por baixo. Ela fica meio que pousando no terreno e tal. E aí fiz, montamos a casa, estamos aqui há quase 30 anos.

Analisando a rede de relações, que já vem sendo discutida desde os capítulos anteriores, percebemos que neste período, apesar de se tornar mais técnica com a entrada de novos profissionais de áreas distintas, algumas das figuras-chave ainda permaneciam. Fica muito explícito no minucioso relato de La Pastina, que mais uma vez prevaleceu a rede de relações na resolução para a sede do Escritório Técnico, o entrave era resultado da falta de apoio pelos técnicos paulistas. Os contatos estabelecidos diretamente com o Rio de Janeiro tiveram, neste momento, a interlocução de Cyro Corrêa Lyra que, apesar de não ser funcionário do IPHAN, tinha trânsito livre nas esferas da instituição, auxiliando nas situações de conflito entre Paraná e São Paulo, tornando-se assim, uma espécie de mediador. Já eram distantes os contatos e conversas como, por exemplo, aquelas que existiam entre 
José Loureiro e Rodrigo Melo Franco de Andrade, uma relação de proximidade, observadas nas cartas aqui discutidas.

Ou seja, o receio da $7^{\mathrm{a}}$ Diretoria frente ao Paraná, era muito explícito nas relações com São Paulo. Qual o motivo desta espécie de boicote da D.R. paulistana? Seria receio pelas relações muito presentes com o Rio de Janeiro, principalmente com Cyro Corrêa Lyra? O próprio tratamento dado à La Pastina, sua atuação solitária frente ao patrimônio paranaense, nos deixa claro esta constatação $^{159}$. Por que a Direção Paulista não demonstrava interesse na implantação de uma sede própria para o escritório técnico? Seria o receio de uma projeção da atuação do Paraná frente ao patrimônio e também das suas relações muito presentes com os técnicos do Rio de Janeiro? Nesse contexto, La Pastina é até acusado pela Diretoria Paulista de que esta ideia seria motivada por interesses pessoais, como relatou em sua entrevista. Receio de que ele poderia eclipsar a atuação de São Paulo?

Apesar das dificuldades enfrentadas pelo Escritório Técnico no Paraná, suas atividades em Paranaguá continuaram, além das obras recorrentes naqueles edifícios tombados pelo IPHAN, na década de 1980 houve o primeiro pedido para o tombamento federal da cidade litorânea, de um representante da sociedade civil. Foi com esta solicitação, que La Pastina deu início aos estudos para avaliar o centro histórico de Paranaguá e a possibilidade de seu reconhecimento nacional. Devemos compreender que neste momento, há uma mudança nas propostas e discursos, deixando um pouco de lado o turismo, preconizado entre os anos de 1960 e 1970, e dando foco à "comunidade" na proteção dos centros históricos, estabelecendo o discurso que nomeava a população como guardiã do patrimônio. (SANT'ANNA, 1995). Segundo Gonçalves (1996, p.76-77): “A categoria povo é entendida como o

\footnotetext{
159 Tanto que La Pastina era chamado de Indivíduo Técnico pelos colegas, tamanha era sua responsabilidade frente ao patrimônio paranaense, Rosina Parchen (2012) comentou durante entrevista: "Ele ficava em São Paulo, ele cumpria o expediente em São Paulo, porque ele não tinha nem sede, aí quando ele conseguiu uma sede, mas isso ele te explica amanhã, quando ele conseguiu vir pro Paraná ele não tinha sede, ele ocupou um espaço aqui da Secretaria da Cultura, a gente emprestou uma sala pra ele ter um indivíduo técnico com endereço! (risos)”
} 
conjunto dos diversos segmentos sociais e comunidades locais que compõem a sociedade brasileira. Em sua narrativa, eles são os personagens principais.”

Os pedidos de tombamento advindos da iniciativa popular tomam uma considerável proporção a partir dos anos de 1970. Segundo Maria Cecília Londres (2009), o que antes eram, majoritariamente, procedimentos comuns dentro da instituição do Patrimônio, inverte-se para a predominância dos pedidos externos, isso não significa que todos fossem originários da sociedade civil, mas já mostrava ser um passo em direção à democratização das atividades do patrimônio. E até podemos considerar a descentralização do IPHAN como efeito destas inciativas.

São mudanças que permitiram a promoção de debates sobre a atuação do Serviço do Patrimônio desde as primeiras décadas e que também atingiram os conteúdos da Revista do IPHAN, por exemplo, se compararmos o conteúdo da revista n 18 de 1978 e a de no 22 de 1987 vemos que a edição de 1978 ainda trata de temas muito restritos a arquitetura e a arte barroca, dentre os quais Aleijadinho, pintura colonial em Minas Gerais e monumentos do século XVIII, no entanto, a edição de 1987, alusiva às comemorações dos 50 anos do IPHAN, traz discussões e reflexões sobre a atuação da instituição nas últimas cinco décadas, com temas que abrangem política cultural, legislação, tombamento, restauração, patrimônio documental e patrimônio arqueológico e natural. A revista tem como autores dos artigos, muitos daqueles que são responsáveis pelas primeiras análises críticas sobre o papel e atuação da instituição, vale citar, Antonio Augusto Arantes, Lia Motta, Sônia Rabelo, Ulpiano Bezerra de Menezes e Sergio Miceli. Também é importante destacar o artigo de Vera Bosi, que relatou a experiência na recuperação do centro histórico de Olinda com a participação dos moradores ${ }^{160}$

\footnotetext{
${ }^{160}$ Foram consultadas as Revistas do Patrimônio Histórico e Artístico Nacional nº18 de 1978 e n 22 de 1987 . No texto intitulado Participação e Pesquisa na Preservação do Patrimônio Cultural, Vera Bosi (1987, p. 142) comenta: “Assim, o papel da SPHAN, que tem Diretorias instaladas em todas as regiões brasileiras, deve ser, ao mesmo tempo, propagador de ideias e orientações técnicas e receptor de sugestões e solicitações que sejam respaldadas pelo apoio das comunidades. Ao mesmo tempo em que desempenha o papel de polícia que lhe é outorgado legalmente, a SPHAN deve acompanhar, cadastrar e analisar os trabalhos locais para fomento de novas ideias e ajustamento da política."
} 
Nesse panorama de mudanças, em Paranaguá, os anos 1980 foram marcados por algumas situações que definiram o caráter histórico da cidade em âmbito nacional. Em 1983 a Sociedade Brasileira de Heráldica e Medalhística enviou carta $^{161}$ à Diretoria Regional do IPHAN em São Paulo solicitando que Paranaguá se tornasse "cidade monumento nacional" e a Estrada de Ferro Paranaguá-Curitiba em "monumento nacional". A instituição tinha o apoio do prefeito Waldyr Salmon, dos Institutos Históricos de Paranaguá e do Paraná, da Academia Paulistana de História e de mais algumas instituições. A partir daí, no mesmo ano, constam registros de uma proposta para inserir Paranaguá na lista para candidatura a patrimônio mundial, em conjunto com Igarassu no Pernambuco, a cidade de Goiás, em Goiás e Paraty no Estado do Rio de Janeiro ${ }^{162}$. Mas ainda era necessário o levantamento do conjunto de Paranaguá, mas em 1984 foi dado início às atividades de estudo para a delimitação:

No âmbito da $9^{a}$ D.R, iniciamos em 1984, os estudos para a delimitação da área do setor histórico a ser proposta para tombamento pela SPHAN. Por falta de condições operacionais (recursos humanos e financeiros) do Escritório Técnico do Paraná o trabalho não foi concluído. Todo o material produzido (mapa, fotos, textos, levantamentos etc.) foi emprestado à Secretaria de Cultura e nas reuniões preliminares da qual participamos, ficou estabelecido que a área definida como de preservação rigorosa será a mesma a ser proposta para o tombamento pela SPHAN. ${ }^{163}$

O levantamento foi realizado por La Pastina em 1984 (Figura 59), frente ao Escritório Técnico, que resultou num documento contendo plantas das quadras e de fotografias dos edifícios, todos numerados e locados nestes desenhos. Segundo La Pastina (2012):

\footnotetext{
161 Carta ao Diretor Antônio Luiz Dias de Andrade de 13 de outubro de 1983 (Arquivo Central). O pedido pela sociedade se deve ao envolvimento do seu presidente Roberto de Aquino Lordy nas buscas pelos restos de um navio pirata na baía de Paranaguá desde os anos 1960. Foi ele o responsável pela primeira solicitação para o tombamento de Paranaguá

162 Parecer dado em 24 de abril de 1985 por Augusto da Silva Telles relatando sobre as possíveis candidaturas e aconselhando reuniões para se estabelecerem critérios e discutirem as escolhas. (Arquivo Central).

163 Carta da historiadora Márcia Chuva à Coordenadora de Proteção em 22 de maio de 1987 (Iphan-PR)
} 
Esse não foi em 84 foi até antes que eu comecei, foi quando eu desenvolvi a metodologia de análise de centros históricos baseado em cartografia, descrições e tudo o que você pode juntar de informações pra você estabelecer a dinâmica, eu tenho o texto e vou passar pra você também. Então eu fiz uma documentação fotográfica, peguei os vários mapas e também eu vou mostrar pra você, mostrando a foto atual se essa construção aparecia na planta do XVIII, na planta do XIX e tal sabe? Mostrando isso, aí foi feita uma análise de cada casa, mas isso serviu de subsídio para o tombamento Estadual, então a gente trabalhou muito junto com o Estadual e depois a gente mandou todo esse material pra compor o processo de tombamento federal e aí claro estava defasado então a instância central pediu uma atualização do estudo da delimitação.

Figura 59: Um dos trechos do levantamento de José La Pastina para o centro histórico de Paranaguá, os edifícios foram catalogados e localizados num mapa base de fins do século XIX. Fonte: Arquivo IPHAN-PR
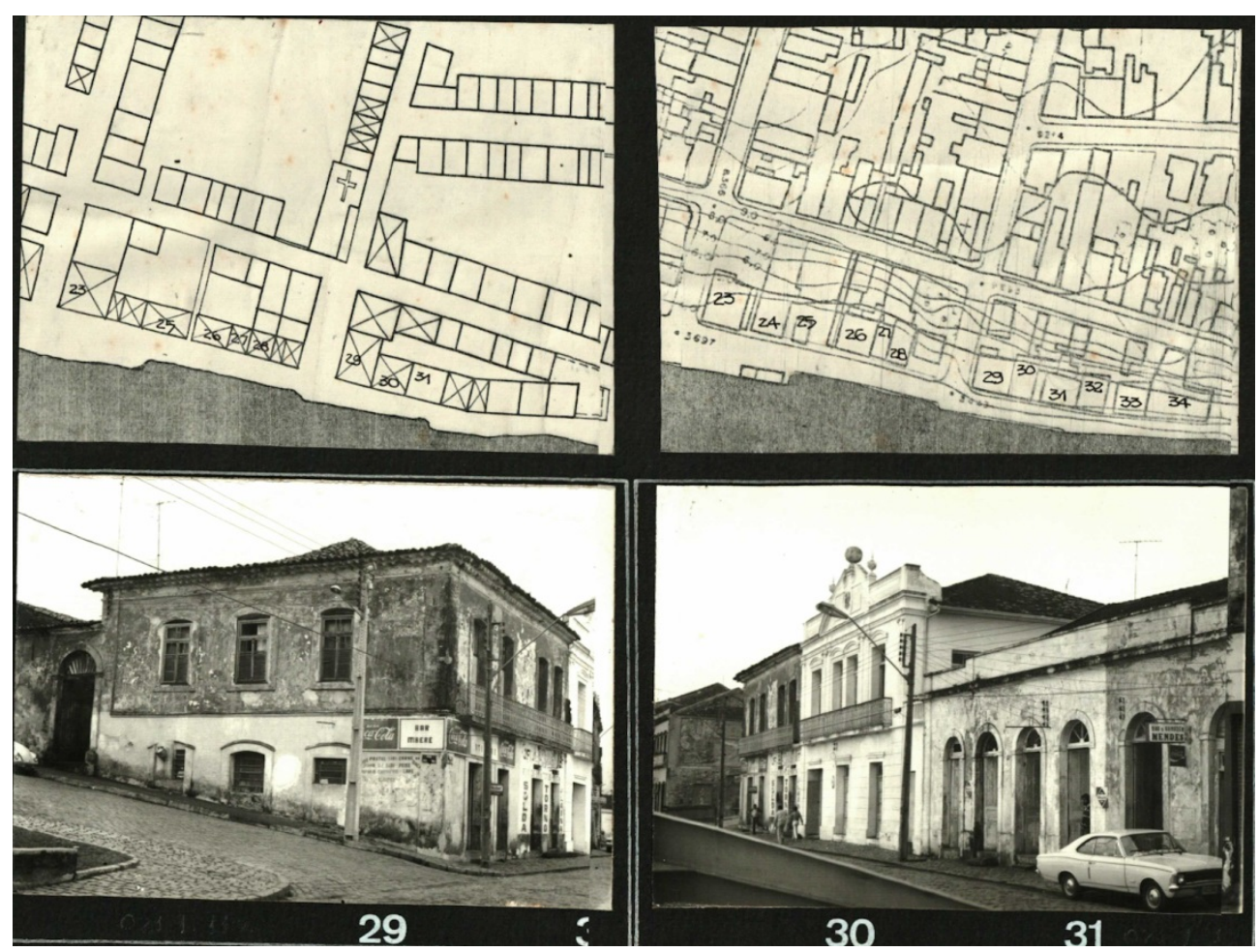

Mas infelizmente este trabalho não foi encerrado, pela falta de auxílio técnico, pois o levantamento foi realizado apenas por La Pastina. Por que não houve nenhum auxílio dos técnicos de São Paulo? Todo o material foi encaminhado à Secretaria de Cultura para análise e "[...] ficou estabelecido que a área definida como de preservação rigorosa será a mesma a ser proposta para o tombamento pela SPHAN."164

Em 1984, foram estabelecidos contatos entre Antônio Luiz Dias de Andrade e a Chefe da Curadoria do Patrimônio Histórico e Artístico do Paraná, Jussara

164 Parecer de Edgar Acosta Diaz em 24/06/1986. (Arquivo Central) 
Valentini. As cartas referem-se a solicitações para o envio de documentação e levantamentos que servirão de base para a análise do pedido de tombamento federal. Os dados foram enviados, mas a Chefe justifica que não possuía informações recentes sobre o conjunto. $\mathrm{O}$ material encaminhado a São Paulo foi posteriormente enviado para a Coordenadora do Setor de Tombamento Dora de Alcântara.

A gestão do prefeito Waldyr Salmon (1982-1988) foi importante no âmbito da preservação do patrimônio e existia interesse, não apenas na preservação daqueles monumentos consagrados, mas também na inclusão de Paranaguá no rol de cidades históricas tombadas pelo IPHAN. Em sua gestão, Salmon foi responsável pela criação de um setor encarregado de tratar das questões relacionadas ao centro histórico. Suas ações na cidade resultaram no reconhecimento pelo IPHAN, recebendo a medalha comemorativa "Rodrigo Melo Franco de Andrade" em 1988. ${ }^{165}$

Durante a gestão de Salmon, foi apresentado o documento intitulado Programa de Recuperação e Revitalização de Núcleos Históricos, elaborado pela arquiteta Eliane Regina Bugay, da Secretaria de Planejamento Urbano da Prefeitura Municipal de Paranaguá. Neste documento em que são descritas as atividades relacionadas ao centro histórico de Paranaguá e a proposta para sua proteção.

Em 1988 o prefeito Waldyr Salmon solicitou ao IPHAN o tombamento do centro histórico de Paranaguá, alegando que realizara ações de valorização do patrimônio, já citadas anteriormente e incluindo a organização de um evento intitulado $1^{\circ}$ Encontro para a Preservação dos Centros Históricos Paranaenses ${ }^{166}$. Foi neste encontro que José La Pastina apresentou a pesquisa intitulada Aspectos da Evolução Urbana de Paranaguá em que analisava as transformações da cidade desde a pequena

\footnotetext{
165 Publicado no Jornal local Diário do Comércio em 16 de janeiro de 1988, com o título Ao receber medalha Prefeito pede o tombamento de Paranaguá.

166 Carta do prefeito Waldyr Salmon ao presidente do Pró-memória, Oswaldo José de Campos Melo em 12 de janeiro de 1988. (Arquivo Iphan-Pr)
} 
vila, a chegada da ferrovia e a construção do novo porto na baía de Paranaguá. Sobre o evento, descreveu BUGAY (1988, p.04):

Em outubro de 1987, numa ação conjunta da Prefeitura Municipal com a Secretaria do Estado da Cultura e FAMEPAR, foram reiniciados os estudos sobre o Centro Histórico. Nos dias 01, 02 e 03 de dezembro do mesmo ano, a nova proposta de Lei redefinindo limites e critérios de intervenção para a área foi amplamente discutida com a população no $1^{\circ}$ Encontro para a Preservação dos Centros Históricos Paranaenses. A participação de profissionais que desenvolvem trabalhos semelhantes em outras cidades do Paraná, bem como de inúmeros técnicos de outros estados, contribuiu para esclarecer a população a noção do bem preservado como objeto vivo, dinâmico, e não como elemento estático, de culto.

O documento estabeleceu diretrizes que nortearam a elaboração de medidas para a salvaguarda do centro histórico de Paranaguá, dentre as quais vale citar a elaboração de legislação específica para a área, a análise da infraestrutura urbana, a inventariação dos imóveis e, em destaque, a necessidade de conscientização dos moradores sobre a proteção do centro histórico. Nesse aspecto, foram tomadas medidas, como a organização de reuniões com associações de bairros, sindicatos, entidades e escolas, a elaboração de cartilhas explicativas, a montagem de exposição fotográfica e até a criação de uma equipe de profissionais locais para obras emergenciais em edifícios históricos (pedreiro, carpinteiro e dois ajudantes).

A carta do prefeito Waldyr Salmon foi a segunda solicitação para o tombamento do centro histórico ${ }^{167}$ e causou estranhamento na central carioca, como podemos constatar na manifestação da historiadora Márcia Chuva encaminhada à Jurema Kopke, alegando a falta de documentação e estudos mais aprofundados:

Para elaboração do PT/88, a $9^{a}$ DR estabeleceu como uma de suas prioridades o processo em questão, não encaminhando, contudo, resposta às nossas solicitações, nem tampouco estudos que possibilitassem a instrução do processo de tombamento priorizado. Estranha-nos tal situação, posto que um novo pedido de tombamento

167 A primeira solicitação foi da Sociedade Brasileira de Heráldica e Medalhística em 1983. 
foi feito, em jan/88, partindo agora da Prefeitura Municipal de Paranaguá/Pr, apresentando um quadro de estreito relacionamento com a representação local da SPHAN/FNPM, tendo inclusive desenvolvido trabalhos conjuntos como uma "nova proposta de legislação para Preservação" com a participação dos Centros Históricos Paranaenses. ${ }^{168}$

Mas quais estudos deveriam ser desenvolvidos para que fosse possível uma candidatura de Paranaguá ao tombamento? Quais documentos eram necessários? Até houve, pelos técnicos do IPHAN, a proposta de parceria para a realização dos levantamentos necessários, o que não foi executado. Apenas em 1987 os técnicos cariocas souberam sobre o levantamento realizado por La Pastina em 1984, quando do primeiro pedido de tombamento, ou seja, é provável que os diálogos entre a $9^{\mathrm{a}}$ Diretoria e o Escritório Técnico não fossem reportados ao Escritório Central no Rio de Janeiro, pois se estivessem em contato, estes levantamentos constariam nos arquivos da Central carioca. ${ }^{169}$ Havia problemas no diálogo não só entre Prefeitura e $9^{a}$ D.R, mas também entre a direção paulista e a central carioca, os procedimentos foram conduzidos a passos lentos, o que permitiu, um ano depois, uma das maiores ameaças ao centro histórico de Paranaguá, após as eleições de 1988, com a vitória de José Vicente Elias para o cargo de prefeito. Também há a que considerar que essas dificuldades de comunicação possam ter se agravado em decorrência da desestruturação da instituição federal durante o governo de Fernando Collor (19901992), com a criação do IBPC (Instituto Brasileiro do Patrimônio Cultural) em 1990, que "[...] produziu uma quebra na continuidade de uma política estatal que se caracterizava pela estabilidade." (LONDRES, 2009, p.218). Foi uma fase de enfraquecimento da instituição frente à proteção do patrimônio cultural.

De qualquer forma, no âmbito local a situação estava se complicando, pois no primeiro ano do novo mandato, em dezembro de 1989, entrou em votação na Câmara Municipal de Paranaguá a proposta elaborada pelo vereador Antonio Pioli

\footnotetext{
${ }^{168}$ Carta de Márcia Chuva, endereçada à coordenadora da SPHAN/FNPM Jurema Kopke em 20 de agosto de 1988. (IPHAN-PR).

${ }^{169}$ Carta de Márcia Chuva à Coordenadora de Proteção da SPHAN/FNPM Dora M.S. de Alcântara em 29 de maio de 1987. (Arquivo IPHAN-PR)
} 
que consistia em modificar o inciso II da Lei $n^{\circ} 773$, aprovada em 1969. Esta é lei que é parte integrante do Plano Diretor elaborado na década de 1960 por Cyro Corrêa Lyra e o inciso II regulamenta as alturas permitidas em construções novas nas áreas próximas ao centro histórico. De acordo com essa lei, as construções nas Ruas Conselheiro Sinimbú ${ }^{170}$ e XV de Novembro $^{171}$ não poderiam ter altura maior que 6 metros e no caso de construções com cumeeira paralela à rua, o máximo era 10 metros, em outras vias eram limitados em até 9 metros e cumeeiras paralelas a rua, até 12 metros. Pela proposta do vereador Pioli, isso era alterado para 10 metros, com cumeeira paralela à rua para 20 metros e incluiu um novo artigo:

Art. 2: Fica extinto, para todos os efeitos legais, o "Centro Histórico de Paranaguá", extraído e criado pelo Plano Diretor de Paranaguá e delimitado a SO pela rua dos Expedicionários; a NO pela rua Vieira dos Santos, Praça Eufrásio Corrêa, rua Dr. Leocádio e rua Faria Sobrinho; a NE pela rua Manoel Bonifácio e a SE pelo rio Itiberê, conforme memorial descritivo e planta de localização, contidos e aprovados pela lei 773/69.

Isso significa que ruas importantes do centro histórico como a XV de Novembro onde está situada a igreja da Ordem, seriam autorizadas a construção de edifícios de aproximadamente sete pavimentos, alterando gravemente a escala urbana ainda mantida, além de outros impactos que edifícios desse tipo poderiam trazer ao traçado urbano dessa área. Houve o apoio da imprensa local, jornais como o Diário do Comercio apontam a proposta de lei como uma medida de progresso para a cidade:

$\mathrm{Na}$ realidade, esse projeto visa instrumentar as pessoas que desejam construir no centro histórico de Paranaguá, onde existem residências apenas com valores patrimoniais e que, para construir edifícios devem obedecer uma alternativa que não traria o progresso desejado, pois no Rio de Janeiro, Santos, Minas Gerais e outras cidades existe uma convivência normal entre um edifício de 10 andares e do lado um patrimônio histórico desde que realmente o seja. ${ }^{172}$

\footnotetext{
${ }^{170}$ Rua onde está localizada a igreja de São Benedito.

${ }^{171}$ Rua da igreja da Ordem e do Colégio dos Jesuítas.

172 Trecho da reportagem "Projeto de lei quer a extinção do Centro Histórico" de 8 de dezembro de 1989.
} 
A mudança na Lei foi aprovada e outras propostas foram apresentadas, em 1990, com a elaboração de um novo Plano Diretor. A Lei 1592 de 28 de fevereiro de 1990, faz mudanças no inciso IV da Lei $\mathrm{n}^{\circ} 773$ de 1969, permitindo a verticalização em quase toda da área do centro histórico, sem estabelecer limites de altura, exceto na Rua da Praia e no largo da Matriz, além de criar um novo critério para a definição das áreas a serem preservadas, chamados "pontos históricos", analisados previamente pelos poderes municipal, estadual e federal.

Assim, a partir da primeira proposta do vereador Pioli e sua divulgação nos meios de comunicação, alguns moradores encaminharam denúncias sobre as ameaças ao representante do IPHAN no Paraná. Infelizmente, poucas informações sobre estes movimentos foram encontradas nos arquivos, uma das poucas cartas foi enviada por um aluno da Faculdade local denunciando ao IPHAN sobre as mudanças propostas ${ }^{173}$ Também constatamos a carta do Secretário do Estado e da Cultura, Renée Dotti, enviada ao Procurador da República, a fim de evitar a aprovação das mudanças. Essas mudanças, lideradas pelo prefeito Vicente Elias e aprovadas como Lei n ${ }^{\circ} 1592$, foram um artifício para evitar maiores polêmicas, pois a primeira lei anulava o setor histórico, enquanto que na segunda proposta, a que foi aprovada, foram criados os "pontos históricos" ". Além disso, Elias criou a Fundação Cultural de Paranaguá, em substituição ao Conselho Municipal de Cultura, em funcionamento desde 1974, e solicitou que o IPHAN devolvesse toda a documentação relacionada a cidade, causando estranheza pelo Diretor do Escritório Técnico. ${ }^{175}$

\footnotetext{
173 A carta denúncia para La Pastina foi do aluno do curso de História da FUNFAFI, Luiz César Rodrigues em 15 de dezembro de 1989. (Arquivo IPHAN-PR).

174 Vicente Elias apontou em uma entrevista que: “o Centro Histórico de Paranaguá já está superado”, pois "uma cidade que cresce verticalmente só traz benefícios", para isso, um novo zoneamento seria criado com a manutenção de alguns edifícios, denominados "pontos históricos", de acordo com escolha a ser realizada pela Prefeitura Municipal. (O ESTADO DO PARANÁ, 1989)

175 Em carta de La Pastina respondendo as solicitações do prefeito Vicente Elias de 2 de março de 1990 : “Quanto à vossa solicitação, informamos que todos os documentos existentes em nossos arquivos são cópias de documentos originais de várias fontes e/ou de produção dos técnicos deste Escritório. Por este motivo estranhamos os termos utilizados por V.Sa. solicitando a devolução de todo o material documental sob a guarda da SPHAN para a Fundação Municipal de Cultura." (Arquivo IPHAN-PR).
} 
Desse modo, a solução para o entrave veio do Governo do Estado. Houve uma rápida mobilização da Secretaria de Cultura e da Coordenação do Patrimônio no Paraná que redundou na organização, em 14 de novembro de 1990, de uma reunião do Conselho Estadual do Patrimônio Histórico e Artístico, em que foi apresentada uma nova proposta de delimitação do centro histórico de Paranaguá, baseando-se no plano de 1969, bem como a criação de uma área envoltória (Figura 60). De acordo com o relato de La Pastina (2012):

E aí, em 89, uma das administrações municipais aprovou uma lei na Câmara reduzindo o centro histórico a duas linhas, sabe a linha rua da Praia e o largo da igreja e aí a gente: bom, vai ter que tombar pelo patrimônio estadual. Então fizemos um grupo de trabalho, estudamos, eu fiz uma maquete do centro histórico de Paranaguá e nessa maquete eu plotei os dados de uma planta do final do século XVIII, ou início do século XIX, que é a planta mais antiga que nós temos, plotei os dados numa base cartográfica atual, né, então eu tenho a planta final do XVIII.

Foi este recurso, elaborado pelo Escritório Técnico do IPHAN e pela Secretaria de Cultura do estado do Paraná, que evitou a aplicação da nova legislação municipal. Obviamente houve o pedido de impugnação encaminhado pela gestão de Vicente Elias em 29 de novembro de 1990, do qual vale citar um dos trechos ${ }^{176}$ :

O Edital ora impugnado é genérico, tombando prédios, ruas e locais sem qualquer critério técnico. A prosperar esse tombamento indiscriminado, prédios recentemente construídos passarão à condição de monumentos invioláveis. Ruas com casas sem o menor resquício de arquitetura apurada, edificações clandestinas, construções irregulares, serão intocáveis.

Em resposta, são apresentados um abaixo assinado promovido pelo movimento S.O.S Paranaguá ${ }^{177}$ à favor da manutenção do tombamento e

\footnotetext{
176 Carta do prefeito José Vicente Elias a Curadora do Patrimônio Histórico e Artístico do Paraná, Rosina Coeli Parchen em 29 de novembro de 1990. (Arquivo da Curadoria do Patrimônio Cultural do Paraná).

177 O arquiteto Luiz Marcelo, da Prefeitura de Paranaguá, em entrevista, quando questionado sobre o movimento popular contra a anulação da delimitação do centro histórico, respondeu: [...] formaram o SOS Paranaguá, eles fizeram um plastiquinho pra por no carro e era a imagem de um edifício que foi demolido na rua XV, na frente daquela pracinha da rua XV onde tem um estacionamento, ali tinha um palácio lindo! Chamado Palais Royal, parecido com a agência de rendas do palácio Mathias Bohn e ele foi demolido porque disse que era velho e ele só tinha 70 anos, imagine ele foi demolido, um caos aquilo! Aí todo mundo ficou louco e fizeram o movimento. (MATOS, 2013).
} 
reafirmando as denúncias às ações predatórias ao patrimônio parnaguara promovidas pela Prefeitura, as alterações na legislação que regiam o centro histórico e destacando a Constituição de 1988 que permitiu maiores possibilidades jurídicas para a preservação do patrimônio cultural brasileiro. Foram estabelecidos novos critérios de análise, não apenas de caráter estético, mas também contando com os valores históricos e culturais, resultantes das mudanças nos quesitos para a justificativa de proteção de áreas urbanas e que se referem aos conceitos da cidademonumento para a cidade-documento como destaca Márcia Sant'Anna (1995). Isso pode ser observado na resposta do Conselho ao Prefeito de Paranaguá. Segundo o Conselheiro Ruy Correia Feuerschuette (1990, p.03):

\footnotetext{
Cumpre observar que em Paranaguá nasceram e viveram nossos antepassados: Nilo Cairo, Iria Correia, Fernando Amaro, Leocádio Correia, Santos Andrade, Visconde de Nácar, Barão do Serro Azul, Eufrásio Correia e tantos outros.

É inegável que muitas das edificações desta área guardam importante parte da história e da cultura paranaense.
}

Com isso, o tombamento estadual foi aprovado em dezembro de 1990, em conjunto com a norma de proteção do centro histórico, elaborado pelos técnicos da Secretaria de Planejamento do Estado do Paraná, Milton Karan da Famepar (Fundação de Assistência aos Municípios do Estado do Paraná), Rosina Parchen da Secretaria do Estado e da Cultura e José La Pastina do Escritório Técnico do IPHAN. Há uma ausência de documentos relativos à Diretoria de São Paulo, ao qual efetivamente o Escritório Técnico estava subordinado. Todo o desenvolvimento do estudo até a finalização da proposta para o tombamento foi realizado totalmente em âmbito paranaense, sem nenhuma participação de técnicos paulistas. 
PARANAGUÁ: IDENTIDADE E PRESERVAÇÃO

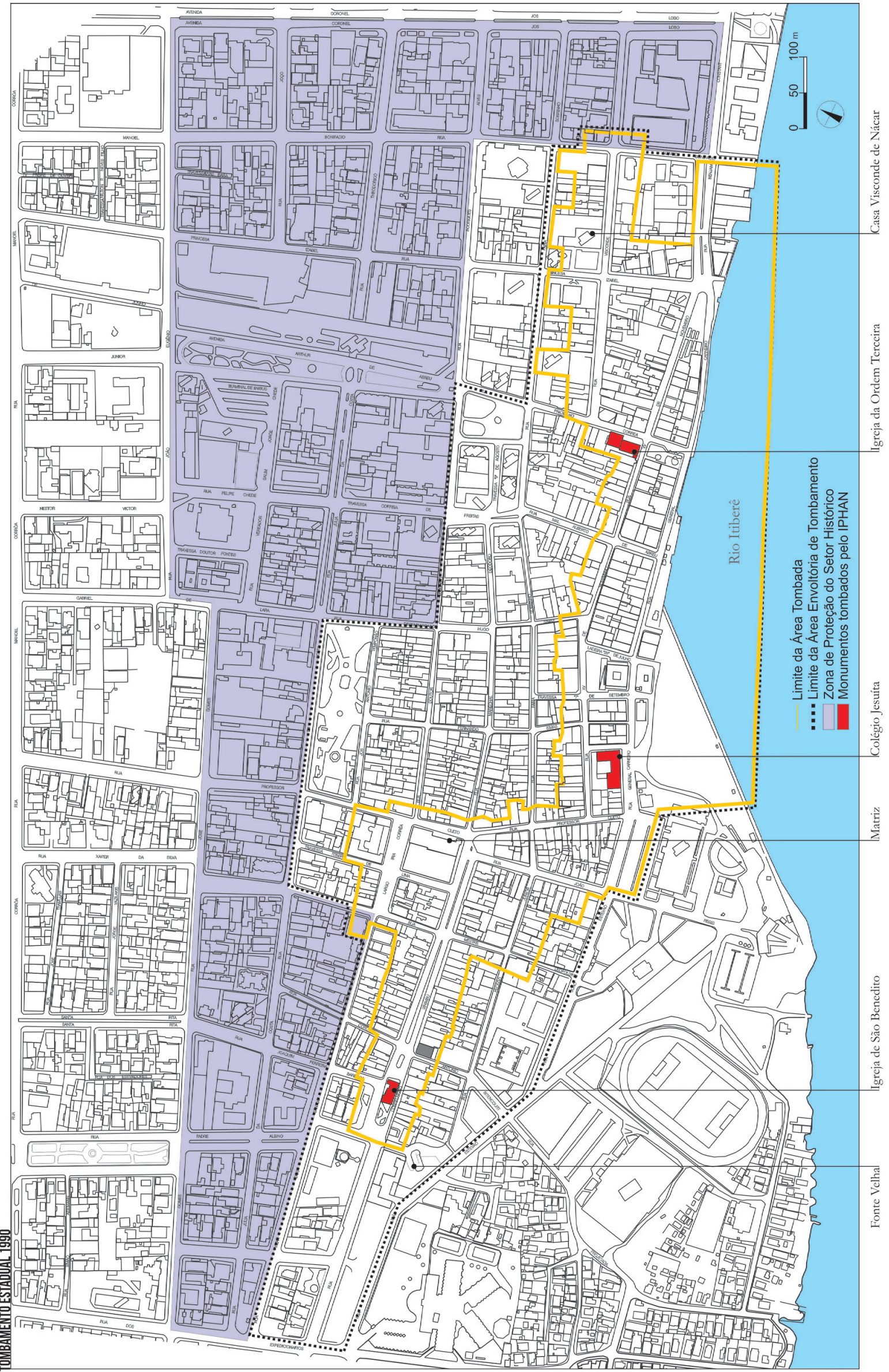

Figura 60: Mapa da delimitação do tombamento estadual.

Fonte: Instrução do Processo de Tombamento do Centro Histórico de Paranaguá, 2007/Adaptado pelo autor 2015 
Após o fim da traumática gestão de Vicente Elias frente à Prefeitura Municipal de Paranaguá, a próxima legislatura, ao contrário da anterior, teve como um dos principais programas de governo a proteção do centro histórico, contando com a participação de profissionais da área do patrimônio. Foi na gestão do sindicalista Carlos Antonio Tortato (1992-1995) que houve a contratação de um arquiteto para elaborar um plano de recuperação do centro histórico de Paranaguá. O profissional escolhido, Luiz Marcelo Bertoli de Mattos era lotado na Curadoria do Patrimônio Histórico e Artístico do Paraná ${ }^{178}$ e aceitou o encargo sob a condição de poder participar do Curso de Especialização em Restauração e Conservação de Monumentos e Centros Históricos ${ }^{179}$ com o tema de Paranaguá:

O curso foi magnífico porque ele foi muito completo. Os maiores técnicos de restauro do Brasil estavam na Bahia. Era a época da restauração do Pelourinho que foi um desastre na época, que ela foi produzida a toque de caixa pra mostrar o poder do senhor Malvadeza. Como chamava ? O ACM, meus professores só falavam: Porque o Malvadeza fez isso, porque Malvadeza fez, aquilo. O apelido dele era Toninho Malvadeza e eles só chamavam pelo sobrenome, enfim ele ganhou um saco de dinheiro porque ele defendeu o Collor, o Collor deu um saco de dinheiro pra ele. Ele fez o milagre de restaurar o Pelourinho, que tava podre há 300 anos, a toque de caixa. Então foi uma análise crítica muito profunda, porque a gente viu a quantidade de absurdos e erros que ocorreram na restauração do Pelourinho. Quanta coisa se perdeu, quanta coisa, para fazer a restauração rápida, foi meio pasteurizada. Eles acabaram com os fundos que tinham uns sítios arqueológicos. Devia estar tudo ali, então mexeram em tudo, deixaram tudo muito pasteurizado. Então era uma época muito efervescente, quando nós fizemos o curso, com senso critico muito grande. Nós tivemos professores, os melhores brasileiros na época, tivemos professores italianos, professores alemães, argentinos. Era uma equipe tão completa

\footnotetext{
178 A Curadoria do Patrimônio Histórico e Artístico do Paraná foi criada em 1979 substituindo a Divisão do Patrimônio Histórico e Artístico pertencente a Secretaria de Estado da Cultura. Sobre sua ida à Paranaguá, comenta Luiz Marcelo (2012): [...] quando aquele prefeito saiu, o Vicente Elias, eu fui convidado por uma engenheira, ela pediu para a Secretaria da Cultura mandar um arquiteto pra cá, pra fazer um projeto, ela trabalhava no porto, engenheira Maria José Marcondes, magnífica. O nome dela deve ser citado: engenheira Maria José Marcondes Lobo! Ela era Secretária de Obras da gestão que ia ganhar e como ela tinha ganho a pintura do Instituto de Educação ela pensou que o Instituto com toda aquela riqueza de detalhes, ele sempre pintado de cinza, como tudo era. Eu na verdade fui um dos primeiros que começou a se preocupar com a cor do patrimônio, de fazer prospecções, tentar descobrir as cores originais antigas, então comecei primeiro a viajar nas cores, e sempre que eu vinha perguntar alguma coisa ela me mandava e eu ia lá e fazia uma pesquisa de cores. Aí eu ia orientando essa pintura do Instituto de Educação. Maria José me conheceu e ficou encantada comigo, eu tava recém-formado, e eu tava pleiteando o curso de restauro da Bahia, daí o Tortato ganhou e ela foi Secretária de Obras e me convidou pra fazer, criar em Paranaguá um Departamento do Patrimônio Histórico [...].

${ }^{179}$ Curso promovido pela Faculdade de Arquitetura da Universidade Federal da Bahia.
} 
e os professores vindos de fora acharam que o nosso curso de restauro era um dos melhores do mundo! (MATTOS, 2012).

A obra de restauro do Pelourinho em Salvador tornou-se um caso de referência nos estudos sobre centros históricos. Sérios problemas ocorreram durante a recuperação dos edifícios que extrapolam às demandas de âmbito mais estritamente técnico, como por exemplo, na proposta de "shopping a céu aberto" que desencadeou na expulsão de antigos moradores. De acordo com Sant'Anna (2004, p.87):

As razões da manutenção do Pelourinho como um empreendimento em permanente estado de coma, plugado no oxigênio da UTI dos cofres públicos são políticas, de concepção e de desenho, além de vinculadas a fatores externos, ligados à dinâmica urbana e econômica da região metropolitana. Mas é sua utilização como instrumento de promoção do governo estadual e vitrine de sua capacidade e eficiência o que explica, em última análise, a permanência de um esquema insustentável nessa área do programa. O excelente acolhimento junto à população reforçou a ideia do governo de manter a intervenção totalmente sob seu controle, evitando parcerias para maximizar os ganhos políticos e de imagem dela decorrentes.

Pela entrevista vemos que o caso do Pelourinho tornou-se uma referência crítica aos alunos do curso de restauração, isso auxiliou na elaboração de seu projeto de Paranaguá, aplicado posteriormente na cidade, que deu importância ao tratamento dos espaços públicos como na criação de uma grande praça sob o aterro defronte ao Colégio dos Jesuítas e a rua da Praia com a recuperação do casario, que se tornou uma importante imagem desta recuperação. Houve também a restauração de alguns edifícios públicos como o sobrado setecentista localizado defronte à Matriz, o Mercado do Café, o Palácio Visconde de Nácar e a Estação Ferroviária, todos do século XIX. Foi proposta a redução da publicidade nas edificações e sua normatização, todas as atividades foram prolongadas até o ano de 2004. 
Foi elaborada a legislação municipal de proteção do centro histórico, aprovada em 1998, estabelecendo graus de proteção que servem para estabelecer critérios de intervenção nos edifícios, este graus que vão do 1 ao 4 referem-se à maneira de intervir em cada um dos edifícios: do mais cuidadoso, respeitando as suas características, até o nível 4 que permite a demolição, sendo que a nova construção deve respeitar as escalas urbanas daquela área. A legislação subdivide o centro histórico em três áreas: Setor Histórico Tombado, Setor Área Envoltória e Zona de Proteção do Setor Histórico, que se referem, respectivamente, à área de tombamento, à área de proteção de visibilidade do conjunto e, por fim, à área de transição para a zona residencial. Foram estabelecidos quatro graus de proteção, desde a proteção mais rigorosa até a permissão de substituição integral, obedecendo as regras pré-estabelecidas. (LEI COMPLEMENTAR, 1998).

Durante as ações de proteção do centro histórico de Paranaguá, promovidas em âmbito Municipal e Estadual, a proposta de tombamento federal, que foi iniciada em 1983 com o primeiro pedido pela Sociedade de Heráldica e Medalhística, continuava sem uma decisão pelo IPHAN. Nos anos de 1990, houve uma varredura pelos técnicos do patrimônio na busca daqueles processos de tombamento que ainda estavam abertos, esta foi uma das inciativas na tentativa de reestabelecer os contatos com as regionais nesses aspectos, pois a instituição passava por momentos de crise em sua organização administrativa, se refere ao período em que foi denominada Instituto Brasileiro do Patrimônio Cultural, criado em 1990 pelo decreto $\mathrm{n}^{\circ} 99.602$ e são criadas unidades descentralizadas, denominadas Coordenação Regional. Neste momento, o Paraná se desvinculou de São Paulo, tornando-se a $10^{a}$ Coordenação, a primeira ideia era ser criada em conjunto com Santa Catarina, com sede em Florianópolis, outros entraves ocorreram para decisão sobre as sedes, como comenta La Pastina (2012):

Nós ficamos durante um ano, Fundação Pró-Memória em Extinção e aí eles viram, você não pode extinguir a obrigação do Estado, pela constituição, de cuidar do patrimônio. Então eles tiveram que recriar o IPHAN e recriaram com outro nome, Instituto Brasileiro do Patrimônio 
Cultural, e a gente brincava, acabaram com o IBC (Instituto Brasileiro do Café) e criaram o Instituto Brasileiro do Pó de Café (risos). Aí depois foi revertida a questão do nome. Aí quando foi criada a Superintendência do Paraná em mil novecentos, acho que noventa, né? Noventa, noventa e um. Aí ela virou Superintendência e nessa época a presidência do IPHAN estava com a antropóloga Lélia Coelho Frota, que era filha do general chamado Sylvio Frota, da linha dura da Ditadura. E ela, acho que puxou o pai, porque ela tomou assim: Vou dirigir o Iphan então o Iphan tem que ser dirigido por arquiteto. Então quem era presidente de núcleos estaduais de arquitetos ia virar superintendente do IPHAN. Aí, aqui no Paraná, seria o IPHAN englobando o Paraná e Santa Catarina. Então ela fez contatos com o IAB de Santa Catarina: Você quer ser diretor superindentente? Ele era de Blumenau. Aí tinha que ser em Floripa e ele não quis. Daí veio aqui: Quer? Aí foi um rolo porque também o Paraná ia ser junto com Santa Catarina. E em Santa Catarina, uma articulação política, disse: Não, Santa Catarina é independente. Daí ficou Paraná e Mato Grosso do Sul. Aí falei: Bom o Paraná não tem nada a ver com o Mato Grosso do Sul, Mato Grosso do Sul é extensão de São Paulo, deveria ficar com São Paulo. Enfim, acabou ficando o Paraná sozinho e entrou então esse presidente do IAB. Ficou até 2003. Aí março de 2003, eu voltei para a Superintendência e continuo até hoje. Fiz 20 anos agora dia 10 de março.

Em 1993, novamente o processo de tombamento federal do centro histórico de Paranaguá foi retomado a pedido do IPHAN, numa política de retomada de processos que ainda estavam abertos:

Tendo-se em vista o objetivo de retomada desses trabalhos dentro de uma diretriz previamente definida, foi elaborado, pelos técnicos desta área, o trabalho intitulado Processos de Tombamento: uma proposta de ação, no qual estabeleceu-se uma dinâmica de atuação, que reafirma a necessária integração entre o DEPROT e as Coordenações regionais para os assuntos dessa natureza. ${ }^{180}$

Há o envolvimento da Coordenação Regional do IPHAN e da Curadoria do Patrimônio Cultural do Paraná, respectivamente José La Pastina e Rosina Parchen, nas atividades de proteção do patrimônio em Paranaguá. Há um grande envolvimento destas instituições que colaboraram e permitiram que recursos federais pudessem ser utilizados nas obras.

180 Carta do Diretor do DEPROT, Sabino Barroso ao Coordenador da $10^{\text {a }}$ CR José La Pastina em 30 de julho de 1993 (Acervo IPHAN-PR). 
O material referente ao processo de tombamento do centro histórico de Paranaguá foi encaminhado em 1996, só três anos depois. O atraso se deu por causa da dificuldade de acesso à documentação, que estava concentrada em São Paulo, houve a necessidade da Superintendência do Paraná fazer cópias de todos os documentos relativos ao processo. Neste momento fica mais claro quais documentos eram necessários para a elaboração da instrução. De acordo com carta de Jurema Kopke Eis Arnaut, eram necessárias informações cartográficas, estudos que se referem à formação de Paranaguá desde o início até aquela data, à análise das tipologias arquitetônicas e urbanísticas do conjunto e à definição das poligonais de tombamento e seus critérios para a preservação. ${ }^{181}$

Os anos de 1990 no Brasil são importantes no que se refere à requalificação de centros históricos, há o caso paradigmático de Salvador, mas também outras iniciativas descentralizadas em nível estadual e municipal, isso provocou uma resposta do Governo Federal em centralizar estes financiamentos:

A implantação da maioria dos novos programas nacionais ocorreu após a explosão de intervenções de re-qualificação e revitalização de sítios históricos nas maiores cidades brasileiras, as quais foram implementadas e financiadas por instâncias estaduais ou municipais. A federalização dos programas de preservação decorreu de uma reação do governo central ao fato de ter perdido o papel de protagonista no financiamento de ações nesse campo, da renovação do interesse de agências multilaterais de desenvolvimento, como o BID, pelo financiamento de projetos ancorados no aproveitamento econômico do patrimônio e das mudanças empreendidas na política nacional de habitação, a partir de 1996. (SANT'ANNA, 2004, p.315)

O Monumenta, criado em 1995, tem por objetivo o financiamento privado para obras de restauração à partir de uma organização pública. Sendo assim, houve o acordo de cooperação técnica com a UNESCO e o financiamento do Banco Interamericano de Desenvolvimento (BID). As atividades definidas foram a elaboração de diretrizes para a utilização dos edifícios privados, incentivos aos

${ }^{181}$ Carta da Gerente de Proteção Jurema Kopke Eis Arnaut ao Superintendente José La Pastina em 26/09/2006 (Acervo IPHAN-PR). 
proprietários com a possibilidade de verbas destinadas às obras de restauração e conservação com juros mais baixos, tendo por condição, preferencialmente, o uso dos edifícios restaurados para atividades de comércio e turismo. (JUNIOR, 2010).

Neste sentido, novamente temos a cidade de Paranaguá incluída em uma iniciativa federal para a preservação do patrimônio, pois estava na lista de cidades contempladas pelo Programa Monumenta, ou seja, fazia parte das prioridades do IPHAN para os investimentos em sua restauração e conservação. Foram catalogados pelo Programa 101 sítios e conjuntos históricos urbanos, esta catalogação foi elaborada por técnicos das Prefeituras e dos Estados à partir de uma ficha padrão. Pela justificativa de seleção do conjunto de Paranaguá temos:

Paranaguá, vila desde 1648, é a cidade mais antiga do atual território do Estado do Paraná. Até meados do século XIX, quando Curitiba tornouse capital da Província, era também o mais importante centro econômico e social. Apesar das mutilações sofridas, a Paranaguá dos séculos XVIII e XIX é ainda perfeitamente identificável no Conjunto Urbano. (MONUMENTA, 2000, p.313).

Vale salientar na justificativa a menção ao século XIX, que durante muito tempo não esteve no foco das atividades do patrimônio. Em relação às mutilações, ocorreram principalmente na gestão de Vicente Elias, perdas consideráveis no conjunto urbano, como também a pavimentação asfáltica de ruas de paralelepípedo do centro histórico, tornando-se polêmica entre os moradores, muitos dos quais contrários a tal decisão ${ }^{182}$. Há um conjunto de situações favoráveis a preservação do patrimônio a partir do ano 2000 e foi na gestão de Luiz Fernando de Almeida (2006-2012) frente ao IPHAN que houve uma ampliação dos tombamentos, ou seja, ampliar o "estoque patrimonial", pois, “[...]estabelecer uma rede de núcleos urbanos formadores do território nacional, era um dos objetivos da gestão em curso. A atribuição de valor aos novos núcleos tombados deveria se fazer a partir de critérios para além dos consagrados na história do IPHAN, como os estético-

\footnotetext{
182 Sobre o asfaltamento, houve a reportagem do programa Fantástico da Rede Globo de 1991 que relatou sobre a obra e a indignação dos moradores. Vídeo localizado no YouTube em: 15/11/2012.
} 
estilísticos." (BRITO; SCIFONI, 2015, p. 31). A ideia também está presente na reunião do Conselho Consultivo do IPHAN em que foram tombadas a cidade de Paranaguá e Iguape:

Exatamente como disse o Presidente, o IPHAN está trazendo a este Conselho o produto de uma estratégia implantada na gestão atual do IPHAN, que visa direcionar os processos de tombamento para análises de territórios culturais, que podem ter base geográfica ou base temática, como é o caso de hoje. Gostaria de trazer mais uma vez à consideração desse Conselho uma série de propostas de tombamento relacionadas com a estratégia do IPHAN de aumentar o estoque patrimonial, a significância do patrimônio do país e a significação do conjunto de bens tombados. (ATA, 2009, p. 2).

Dentro desta política, em 2008 ocorreu a primeira reunião de discussões sobre o tombamento de Paranaguá pelo IPHAN e a entrega dos estudos iniciais para a Instrução, dentre os quais a definição da Poligonal ${ }^{183}$. Na reunião são apresentados alguns estudos que se referem à sua delimitação e surgiram dúvidas, que não constam na Ata. Disso, algumas diretrizes foram sugeridas para dar continuidade aos trabalhos, dentre os quais: não estabelecer graus de proteção, não classificar os imóveis em incluídos e excluídos e a indicação para a inscrição do centro histórico de Paranaguá no Livro do Tombo Arqueológico, Etnográfico e Paisagístico e no Livro do Tombo Histórico. ${ }^{184}$

Esta política ampliou as possibilidades para o tombamento federal de Paranaguá, mas também teve peso o fato do processo continuar em andamento desde os anos de 1980, fazendo com que a cidade ainda estivesse nas frentes de trabalho do IPHAN. É perceptível que, apesar da cidade ter problemas relativos à sua proteção, a inciativa local e a rede de relações permitiram que este processo a mantivesse inserida nos meandros das atividades do Serviço do Patrimônio. Afinal

\footnotetext{
183 Na reunião que aconteceu em Brasília estavam presentes a Gerente de Proteção Jurema Kopke Eis Arnaut, o Superintendente do IPHAN do Paraná José La Pastina e os técnicos da Gerência de Proteção Luis Fernando Franco e Maria Paula Ferguson Marques.

184 Ata da reunião realizada na Gerência de Proteção/DEPAM em Brasília nos dias 18 e 19 de março, com a presença da Gerente de Proteção Jurema Kopke Eis Arnaut, do Superintendente Regional José La Pastina e dos técnicos da GProt, Luis Fernando Franco e Maria Paula Ferguson Marques.
} 
foi uma das cidades discutidas no relatório de Michel Parent, teve uma proposta de delimitação nos anos de 1960, houve interesses locais na preservação de seu patrimônio: todos foram condicionantes importantes que colaboraram no reconhecimento federal de Paranaguá como patrimônio. 


\subsection{A CLASSIFICAÇÃO DO PATRIMÔNIO URBANO: PARANAGUÁ PAISAGEM OU HISTÓRIA?}

Paisagem e História? Ou apenas História? O motivo destas questões se deve ao resultado do tombamento do centro antigo de Paranaguá. Para os membros do Conselho Consultivo do IPHAN, a cidade possui importância histórica, no entanto a Conselheira responsável pelo parecer de tombamento e o Superintendente do IPHAN no Paraná, a cidade possui as duas qualidades. Desta maneira, para compreendermos o resultado do tombamento federal de Paranaguá, apenas em caráter histórico, devemos partir dos procedimentos que permitiram a elaboração do Instrução de Tombamento e principalmente dos envolvidos com os trabalhos: os arquitetos Humberto Fogassa, José La Pastina e Rosina Parchen. A denominada Instrução do Processo de Tombamento do Centro Histórico de Paranaguá foi desenvolvida pelo escritório do arquiteto Humberto Fogassa, antigo estagiário do escritório Aresta, de Cyro Correa Lyra, e ex-aluno do Curso de Especialização em Conservação e Restauração de Monumentos e Conjuntos Históricos em Salvador. A escolha de Fogassa se deu a partir do convite pela Superintendência do IPHAN do Paraná a vários escritórios para apresentarem candidatura no concurso que selecionaria a proposta. A equipe que participou na elaboração era composta por uma arquiteta, uma jornalista, uma restauradora e duas estagiárias. Como consultores desta Instrução, contou com a participação de José La Pastina, Rosina Parchen e Luiz Marcelo Bertoli de Mattos:

Na primeira delimitação, a gente tinha feito a delimitação como na Lapa, por uma linha que passava pelo eixo das ruas e aí todas as casas voltadas pra rua estavam tombadas incluindo as de esquina, quando cruzavam. Tradicionalmente era feita pelo fundo dos lotes e aí a gente fez uma licitação, contratou o Humberto Fogassa pra fazer a complementação de todo esse processo e também com novas metodologias. A gente não tinha aqui estrutura pra fazer as plantas em autocad, mas a gente trabalhou muito junto. Inclusive a descrição da poligonal na verdade eu que fiz, eu tenho experiência e não me custava nada fazer. Enfim foi um trabalho muito interessante e o que é mais gratificante. Assim, então quando fechou o processo e foi feita a notificação, a proposta era que o tombamento de Paranaguá fosse de caráter urbanístico e paisagístico, 
porque a gente entende a moldura da cidade e a relação com o rio é importante. (LA PASTINA, 2012)

Rosina Parchen também comentou sobre sua participação na elaboração da Instrução:

Sim, sim, a base disso foi o tombamento estadual tá, eles pegaram a mesma área, o Humberto veio aqui, pegou todo o nosso material, pesquisou todo o material e foi a campo dentro daquelas fichas do Iphan de preenchimento e tal e fez todo o levantamento conforme o Iphan exigia, dentro da nossa base tá, o que a gente já tinha classificado como unidade de proteção rigorosa, a área mesmo, eu me lembro que ainda num domingo ele tava vindo de Paranaguá, ele passou na minha casa, que eu morava no Jardim América, ele passou na minha casa: Rosina tô vindo de Paranaguá, preciso conversar com você já, porque eu tenho que chegar em casa e fechar isso aqui, que eu tenho que entregar. E ainda nós ficamos trabalhando até o final da noite, ficamos trabalhando até o final da noite de domingo, porque ele estava exatamente fechando os pontos sabe, das intersecções das ruas, ele reclassificou alguns imóveis, alguns já estavam mais decadentes e então eu acompanhei bem de perto, bem de perto. (PARCHEN, 2012)

A decisão e a delimitação do centro histórico de Paranaguá têm a influência direta dos dois profissionais, tanto de José La Pastina como de Rosina Parchen, pois estavam envolvidos há muito tempo nas atividades de proteção do patrimônio parnaguara e naturalmente seriam figuras-chave nessa proposta. Isso se torna claro no depoimento de Humberto Fogassa (2012):

Eu fiz na medida que eu ganhei a proposta, o IPHAN convida as pessoas, fez propostas e convites para várias pessoas, aí apresentamos os custos e etc. A minha intenção, sendo bem franco, eu queria trabalhar com esse universo, de conjunto, pela primeira vez, e Paranaguá, por já ter trabalhado com o $\mathrm{MAE}^{185}$, eu tinha uma familiaridade, eu fui muito à Paranaguá durante um ano, fui exaustivamente, já tinha uma boa parte das informações, porque para fazer o projeto a gente pesquisa a cidade, então eu topei e quis fazer, então o processo de Instrução nos solicitaram toda essa preparação pra que encaminhado esse trabalho, Brasília entendesse e aprovasse o Processo de Tombamento Federal de Paranaguá. Então sendo a primeira vez foi um pouco difícil porque é

185 O Museu de Arqueologia e Etnografia (MAE) sediado no antigo Colégio dos Jesuítas, teve sua última restauração sob-responsabilidade do escritório de Humberto Fogassa. 
muito teórico no sentido de muita pesquisa, muita documentação, sem necessariamente um processo de intervenção mais direta como eu geralmente estou acostumado a fazer. O que a gente fez, a gente trabalhou muito diretamente com o IPHAN.

São três, os principais envolvidos neste estudo, Humberto Fogassa, José La Pastina e Rosina Parchen. De maneira geral, a Instrução de tombamento contempla o histórico da cidade e "evolução urbana de Paranaguá", dando maior ênfase ao século XVIII, faz a análise das tipologias construtivas, destacando a variedade de estilos arquitetônicos e a predominância do uso comercial destes edifícios. Também relata sobre a construção do aterro, considerando como área problemática na orla do rio Itiberê, afetando principalmente a percepção espacial e a relação entre o rio e o Colégio dos Jesuítas. Faz uma análise das vias e a condição de seu calçamento e destaca o papel do arquiteto nesta atividade:

A arquitetura luso-brasileira dos primeiros séculos tem a sua natureza própria. Existe nela, a despeito das discussões de gosto e das divergências conceituais, beleza e harmonia; é partindo dessa premissa que acreditamos que se deva imprimir na proposta de intervenção do arquiteto, na proposta daquele que comanda a operação arquitetônica ou daqueles que vão se beneficiar e viver com ela, a necessidade de se integrar ao que existe previamente, e mesmo quando se concebe um complemento com princípios diferentes, deve-se fazê-lo atribuindo qualidade à relação final que se institua entre eles. (FOGASSA, 2007, p.128).

No texto da Instrução, as análises relativas às construções do século XIX e XX são menores se comparadas com períodos anteriores. O porto foi inserindo no contexto dos ciclos econômicos da Erva-Mate, da Madeira e do Café, contempla a chegada da ferrovia e a transferência do antigo porto das margens do Rio Itiberê para a Baía de Paranaguá, e o coloca como um dos itens a serem preservados, “[...] com sua visão do mar, dos navios e de todo equipamento - guindastes, gruas, locomotivas - de que é dotado.” (FOGASSA, 2008, p.15). A análise de Fogassa nos permite afirmar que existiu um indicativo de proteção do patrimônio tecnológico e industrial? Apesar da proposta de preservação de maquinários e de outros 
equipamentos, tema precioso nas discussões mais recentes sobre o patrimônio da industrialização, este item não foi contemplado na delimitação, como vamos comentar com mais detalhes a seguir.

A delimitação da poligonal de tombamento (Figura 61) definiu que os imóveis externos ao limite também estão incluídos na proteção. Pela delimitação foram listados 150 imóveis incluídos e 105 excluídos que pertencem à poligonal. Também foi delimitada a área envoltória à poligonal de tombamento. A proposta estabelece graus de proteção e a inclusão e exclusão de edifícios, ao contrário do que foi recomendado pela reunião de 2008, esta exclusão foi justificada pelo [...] alto grau de heterogeneidade deste conjunto urbano [...] (FOGASSA, 2007, p.160) os graus de proteção são os mesmos estabelecidos pela legislação municipal de 1998. As escalas são de Grau de Proteção 1, mais rigorosa, que estabelece a manutenção das características do edifício, Grau 2 também proteção rigorosa, mas naqueles casos de edifícios que sofreram alterações que lhes desfiguraram, há de destacar o seguinte trecho "[...] sendo passíveis de intervenções restaurativas que restituam a concepção original." (FOGASSA, 2007, p.160). O que seria a concepção original? O grau 3 são consideradas as unidades de acompanhamento em que devem ser mantidas a volumetria e o Grau 4 permite-se a demolição integral.

Entre as recomendações, estabelece que obras de infraestrutura devem ter a aprovação do IPHAN, define a necessidade do enterramento da rede de distribuição elétrica. Manutenção da pavimentação em paralelepípedos, controle da circulação de veículos. No tratamento paisagístico, estabelece que a inserção de mobiliário urbano e sinalização devem "[...]respeitar as características físicas e paisagísticas do setor.” (FOGASSA, 2007, p.157). 


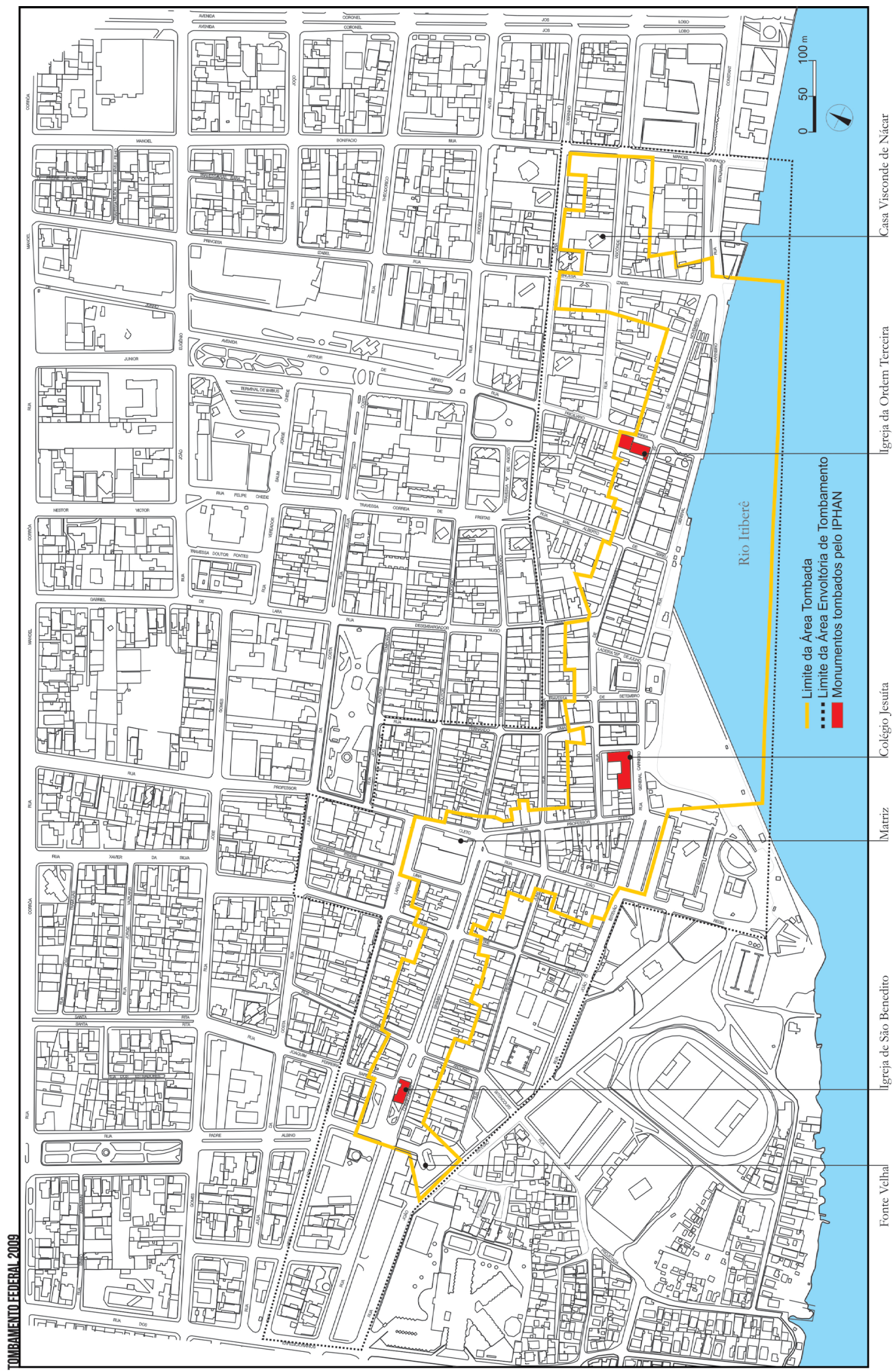

Figura 61: Mapa da delimitação do tombamento Federal.

Fonte: Instrução do Processo de Tombamento do Centro Histórico de Paranaguá, 2007/Adaptado pelo autor 2015 
Das delimitações de 1968 de Cyro Corrêa Lyra, de 1990, elaborada pelo Estado do Paraná e de 2009 o tombamento federal nos permitem estabelecer algumas análises com o intuito de compreender o modus destas delimitações e suas influências, são questionamentos importantes que surgem das três propostas, de décadas distintas, sobre a mesma cidade. A contestação mais visível é a redução da poligonal de tombamento comparada com a primeira proposta de Cyro Corrêa Lyra, que se tornou envoltória, com o traçado muito semelhante ao que o arquiteto propôs. A delimitação do Setor Histórico ficou mais aproximada dos monumentos considerados relevantes: das igrejas, do Colégio e da casa do Visconde de Nácar, por algum motivo desconhecido exclui-se a Fonte Velha, construção do século XVIII. A delimitação se desenha pelo fundo dos lotes e não pelas vias. No entanto, na poligonal proposta para o tombamento federal, esta área se reduz mais ainda, tornando-se evidente a predileção na proteção daqueles monumentos já citados anteriormente, aqui inclui-se novamente a Fonte Velha, a redução também atinge a Área Envoltória, excluindo-se, por exemplo, a Praça dos Leões e ruas importantes como a antiga Direita, ligando a Matriz ao largo da já demolida Capela do Bom Jesus.

Por fim, a delimitação da poligonal de tombamento federal permite alguns questionamentos: o tombamento de áreas urbanas compete apenas à proteção dos monumentos e suas envoltórias? Em relação ao traçado urbano, não foi um item importante nessa delimitação? Pela definição da Carta de Petrópolis ${ }^{186}$ (2004, p.285):

Entende-se como sítio histórico urbano o espaço que concentra testemunhos do fazer cultural da cidade em suas diversas manifestações. Esse sítio histórico urbano deve ser entendido em seu sentido operacional de "área crítica", e não por oposição a espaços nãohistóricos da cidade, já que toda a cidade é um organismo histórico.

186 Divulgada no $1^{\circ}$ Seminário brasileiro para preservação e revitalização de centros históricos. 
Se toda a cidade é "organismo histórico" e que devemos compreendê-la em seus processos de transformação, percebe-se que a delimitação de Paranaguá se restringe à condição dos edifícios, e pouco define a ideia de conjunto, não apenas das edificações, mas também do traçado urbano, apontamos isto porque analisando o traçado da área mais antiga de Paranaguá, muito ainda se mantém daquele do final do século XVIII, exemplos como a Rua Direita, agora denominada Marechal Deodoro (rua à direita da Matriz) ou a Rua Antonio Vieira dos Santos, antiga Rua do Fogo (rua os fundos da Matriz). Mesmo assim, houve a exclusão de vias construídas no final do século XIX e início do XX, nas propostas das reformas urbanas que também atingiram Paranaguá, como a Rua Arthur de Abreu em conjunto com a praça construída na gestão de Caetano Munhoz da Rocha em defronte a Estação Ferroviária, ou a Escola Normal, são duas áreas que estão fora da delimitação, mas que possuem proteção individual, também a Avenida Coronel José Lobo, que foi construída para ligar a cidade ao novo Porto D. Pedro II na baía de Paranaguá em fins do século XIX. A área portuária mais antiga, próxima a Alfândega de Paranaguá, também não foi inserida neste tombamento nem a área da igreja do Rocio, que possui tão evidente relação com a paisagem da baía de Paranaguá.

Em relação à reunião que resultou apenas ao tombamento de caráter histórico, é possível analisar este resultado e buscar compreender a decisão do Conselho Consultivo do IPHAN. Na $62^{a}$ Reunião estavam incluídas duas propostas para tombamento: Iguape e Paranaguá, um dos motivos foi contextualizar o patrimônio a partir de uma visão mais abrangente, ligada neste caso aos estudos de Nestor Goulart Reis Filho sobre as primeiras experiências relativas ao Ciclo do Ouro que ocorreram nas duas regiões no século XVII. Questionados sobre a reunião do Conselho Consultivo e a não inclusão de Paranaguá no Livro Tombo Etnológico, Etnográfico e Paisagístico José La Pastina (2012) comenta: 
E aí então foi aberta a discussão e o conselheiro amigo nosso Ulpiano, não é arquiteto, mas ele começou a questionar o porquê paisagístico. Eu falava: Olha, mas tem toda a moldura da montanha, tem o mar, tá tomando um pedaço do rio é tombado também o rio para evitar aterros e tal. E aí lá pelas tantas a gente percebeu, o presidente do Iphan percebeu que estava gerando um impasse sabe? E que ia acabar não tombando Paranaguá, ele falou assim: Então vamos fazer o seguinte, vamos tombar só no livro histórico e depois a gente vê essa questão do conjunto arquitetônico, urbanistico e paisagístico. Então hoje Paranaguá é tombada apenas no livro do tombo histórico, eu acho que ele merece, deve ser tombado pelo arquitetônico e paisagístico, urbanístico e paisagístico, mas agora a gente tem outras prioridades tal como tá funcionando, deixar para as novas gerações.

Sobre o tema Rosina Parchen (2012) analisa:

Também, porque, bom se eles não se convencem eles não votam né, você vê quase, por causa de uma palavra inscrever no livro do tombo paisagístico, quase que melou, mas ali o professor Nestor fez uma intervenção boa sabe, eu acho que, o único que fez aquela crítica mais assim de dúvida e que estava errada foi o Ulpiano, mas os conselheiros, eu acho engraçado, não sei porque mas toda vez que eu leio um parecer, só teve essa vez que o Ulpiano fez esta crítica e ficou insistindo, que não, que não, que não. Algum conselheiro tem alguma coisa a acrescentar? Ninguém abriu a boca, mas eu queria que pelo menos falassem, mas nem isso, não fala, é engraçado, não sei porque, mas enfim.

$\mathrm{Na}$ reunião estavam presentes José La Pastina que elaborou uma breve apresentação sobre a cidade de Paranaguá e Rosina Parchen que foi a relatora do processo. No conteúdo de seu parecer Rosina destacou, principalmente, as atividades de preservação empreendidas pelo Estado do Paraná e pela Prefeitura Municipal. Como vimos pelo depoimento dos dois arquitetos, a decisão em direcionar Paranaguá para seu tombamento, apenas para o livro do Tombo Histórico, se deve às dúvidas apontadas pelos conselheiros, principalmente na proposta de valor paisagístico, que surgiram a partir de questionamentos dos conselheiros, pois esta característica não estava evidente no parecer e também na Instrução. 
A ideia do valor paisagístico foi justificada pela relatora na reunião, na relação da cidade com o rio Itiberê e a visão a partir do rio, da Serra do Mar. Estas características não foram apontadas na Instrução e na proposta de delimitação. Por que não foi ampliada, por exemplo, a poligonal alcançando a Ilha da Cotinga? A ilha tem grande importância para Paranaguá (Figura 62), pois de acordo com a história da cidade, foi o primeiro território ocupado pelos portugueses antes de chegar ao continente. Em relação à ilha do Valadares, ocupação efetivada no século XX, conhecida pelos músicos de Fandango, expressão musical muito característica desta região, não poderia ser incluída no tombamento? Outra questão, por que nenhuma área do porto localizado na baía de Paranaguá (Figura 63) não foi delimitada nesta poligonal? São aspectos que poderiam revelar o caráter paisagístico da cidade. O próprio aterro poderia ser visto como um elemento de paisagem, pois é parte de um processo de transformações que a cidade passou, causado pelo assoreamento do rio Itiberê, o assoreamento foi uma das causas para a transferência do Porto de Paranaguá, ainda em fins do século XIX, para a baía de mesmo nome.

Figura 62: Panorama da área da foz do Rio Itiberê, o grande morro ao fundo é a ilha da Cotinga. Fonte: Acervo do autor, 2012

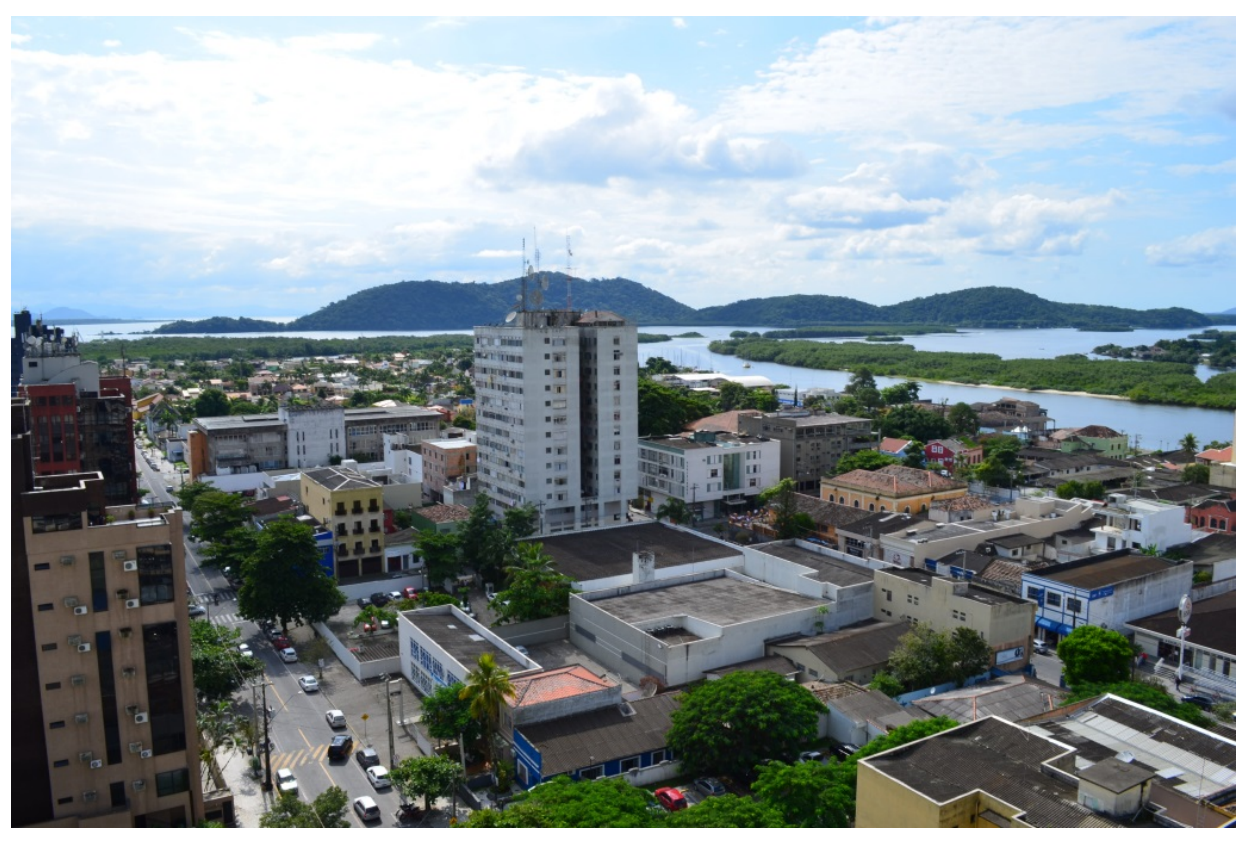




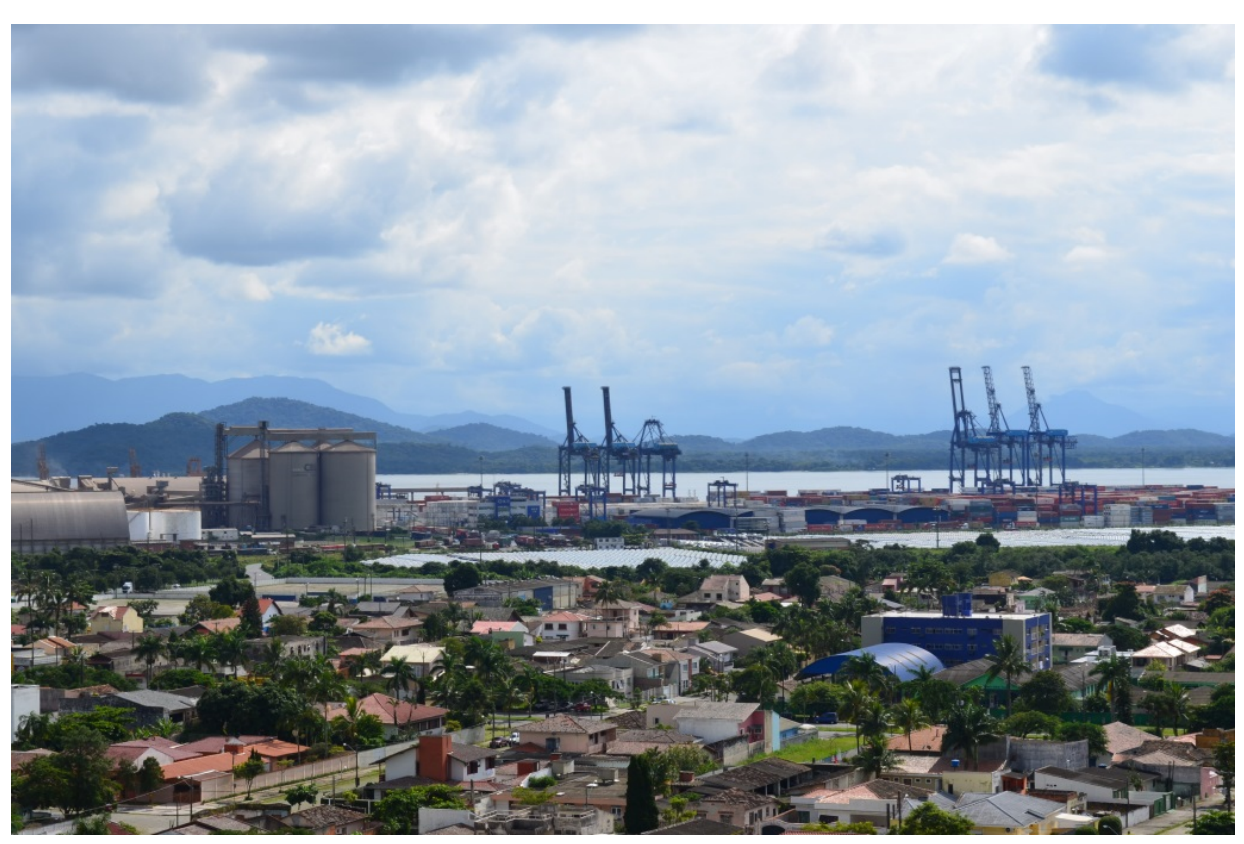

Figura 63: Panorama da área portuária de Paranaguá, como pano de fundo a Baía de Paranaguá e a Serra do Mar.

Fonte: Acervo do autor, 2012

Devemos compreender a paisagem como resultado das transformações e relações estabelecidas pelo homem na natureza. A portaria 127 de 30 de abril de 2009, regulamentada pelo IPHAN, define paisagem cultural, ampliando os conceitos: "Paisagem Cultural Brasileira é uma porção peculiar do território nacional, representativa do processo de interação do homem com o meio natural, à qual a vida e a ciência humana imprimiram marcas ou atribuíram valores (DIÁRIO OFICIAL DA UNIÃO, p. 17, 2009)". De acordo com a recomendação No R(95)9, publicada internacionalmente em 1995 paisagem é:

[...] expressão formal dos numerosos relacionamentos existentes em determinado período entre o indivíduo ou uma sociedade e um território topograficamente definido, cuja aparência é resultado de ação ou cuidados especiais, de fatores naturais e humanos e de uma combinação de ambos. (RECOMENDAÇÃO Nº(95)9, 2004, p. 329).

Já Iguape conseguiu o registro nos dois livros do Tombo. Ao contrário de Paranaguá, a poligonal de tombamento de Iguape deixou claro os parâmetros estabelecidos ao critério paisagístico, pois foram definidos a partir dos processos transformadores da cidade, e não apenas através da seleção de edifícios:

A partir do conceito de cidade-documento, entendeu-se que os processos históricos de formação urbana de Iguape eram o ponto de 
partida para o estudo de seus bens materiais, quer edificados, quer naturais. As edificações em si, informadas simplesmente por seu valor para a historiografia da arquitetura, não interessavam à proteção proposta. O centro histórico de Iguape foi entendido e estudado no âmbito dos processos históricos formadores de sua materialidade. O que significa dizer que, ao se pensar na materialidade urbana de Iguape atentou-se com muito interesse para as inúmeras sobreposições e rearranjos espaciais constituídos ao longo de muitas décadas, entendendo até mesmo a proteção pelo Condephaat como um dos momentos da história da cidade. As representações históricas de diversos momentos eram a parte evidente de sua feição atual e só teria sentido fazer a proteção legal da cidade, tal como ela havia chegado até o momento presente. (NASCIMENTO, SCIFONI, 2015, p.31).

A proposta de tombamento não só englobava a malha urbana de Iguape, mas também inclui o morro da Espia, importante referência histórica e natural da cidade e o Canal do Valo Grande. A análise também contemplou o traçado urbano a partir da ideia portuguesa de planejamento das cidades na Colônia, seus arruamentos, espaços livres e incluiu a antiga área portuária na frente de mar interno (NASCIMENTO, SCIFONI, 2015). Pelo edital de Notificação do Tombamento ${ }^{187}$, são descritos três setores: o Setor do Núcleo Urbano, o Setor do Morro da Espia e o Setor Portuário, são três elementos que definiram as características territoriais, históricas e econômicas de Iguape. Ao contrário de Paranaguá, não foram estabelecidos graus de proteção das edificações, seriam decisões discutidas posteriormente com a população.

Portanto, o tombamento do Centro Histórico de Paranaguá perpassa diversas situações que de alguma maneira afetaram sua proteção, os recursos de lei, como o Plano Diretor de 1968 e o tombamento estadual em 1990 atenuaram em parte estes riscos, no entanto é lamentável que a estreita relação entre a cidade e o porto ainda não esteja evidente nas cercanias do patrimônio. Torna-se perceptível que a delimitação proposta pelo tombamento federal foi reflexo de um processo de seleção e exclusão de edifícios dando privilégios àqueles já consagrados - igrejas e

187 Edital de Notificação: Tombamento do Centro Histórico de Iguape. Disponível em: https://patrimoniovaledoribeira.files.wordpress.com/2014/08/edital-de-notificac3a7c3a3o-tombamento-do-centrohistc3b3rico-de-iguape-sp.pdf 
Colégio dos Jesuítas. A ambiência, motivo de preocupação pelos técnicos, foi condicionante da primeira delimitação e influenciou sobremaneira as decisões seguintes. A instrução, apesar dos avanços no campo teórico e nas práticas da preservação, ainda está arraigada em conceitos que caracterizam a fase Heroica do IPHAN e, provam que estes conceitos, apesar das inúmeras pesquisas e reflexões, ainda circulam pelos meandros do Serviço do Patrimônio. 


\section{4 PARANAGUÁ: O PORTO COMO PAISAGEM}

Paranaguá, assim como diversas cidades pelo país e pelo mundo tem um rio como parte significante de sua história. A intrínseca relação entre a cidade e as águas se tornou muito presente e são simbolizadas, por exemplo, pelas atividades portuárias. Cidades brasileiras como Iguape, Vitória, Recife, Itajaí, Belém, Paraty, São Vicente e tantas outras têm posição estratégica e que permitiu a intensa atividade portuária, também podemos citar, no panorama mundial, Lisboa, Nova York, Porto, Marselha, Nápoles, Le Havre dentre tantas outras que permitiram a ligação entre lugares tão distantes. Quando surgiu a oportunidade de realizar parte da pesquisa no exterior, refletimos sobre uma cidade que pudesse representar esta relação entre porto e espaço urbano: o resultado foi possível com Lisboa e o rio Tejo.

As reflexões aqui apresentadas fazem parte das observações, registros e experiências obtidas durante um período de pesquisas na cidade de Lisboa ${ }^{188}$ e que muito contribuiu no desenvolvimento das discussões sobre a cidade, seus monumentos, o turismo e seus moradores, permitindo a conexão com um caso brasileiro, a cidade de Paranaguá, no litoral do Estado do Paraná. Lisboa é uma cidade ímpar devido às muitas camadas de períodos e eventos do romano, do árabe, do medieval, das navegações, do terremoto, da reconstrução, da República, da ditadura salazarista, da Revolução dos Cravos, entre outros, que delinearam não só a sua história, mas também provocaram transformações em sua configuração e consequentemente na preservação de seu patrimônio.

Mais recentemente, a crise econômica de 2008 que se alastrou pela Europa afetou principalmente Portugal. O país passou a duras penas a pagar empréstimos para evitar sua derrocada, afetando toda a economia, por exemplo, os trabalhadores

\footnotetext{
188 A estadia em Lisboa foi possível através da Bolsa Estagio em Pesquisa no Exterior financiada pela Fundação de Amparo em Pesquisa do Estado de São Paulo e pela permanência na Faculdade de Ciências Sociais em Humanas da Universidade Nova de Lisboa (FCSH-Unova) entre março a agosto de 2014, com a supervisão do investigador Dr. João Mascarenhas Mateus, aos quais agradecemos a oportunidade.
} 
e aposentados sofreram cortes e descontos em seus pagamentos. Isso também afetou os investimentos em diversas áreas e, dentre as quais, não poderia escapar a área da cultura e consequentemente a do patrimônio cultural. Mas isso não anulou iniciativas e algumas obras que aos poucos vem ganhando força na cidade, criando novos espaços públicos de lazer e recuperando seu patrimônio.

Atualmente o otimismo tem ressurgido e o turismo prosperado em Portugal e principalmente em Lisboa. A cidade tornou-se ponto de referência para quem vem à Europa e também para os próprios europeus. ${ }^{189}$

Percebe-se que a cidade cada vez mais incentiva o turismo de eventos e isso foi percebido no ano de 2014: houve o torneio ChampionsLeague, o festival de música Rock in Rio e a comemoração dos 40 anos da Revolução dos Cravos, não esquecendo das festas tradicionais como as Marchas no dia de Santo Antônio, e as festas que ocorrem durante o mês de junho por toda a cidade.

A zona da Baixa e de Belém acabam concentrando a maior parte dos atrativos turísticos e de monumentos (Chiado, Terreiro do Paço, Mosteiro dos Jerônimos, Padrão do Descobrimentos e etc), mas isso tem se expandido para outros cantos da cidade. A região envoltória do Castelo de São Jorge (Figura 64) tem atraído muito a atenção, bairros como Alfama e Mouraria, com seu traçado sinuoso, ruas estreitas e que ainda conservam o antigo casario cada vez mais vem recebendo o olhar dos estrangeiros. O mais recente projeto de intervenção urbana se refere à Mouraria, bairro decadente de Lisboa, que concentrava usuários de drogas e está ligado aos antigos moradores de baixa renda, que são principalmente imigrantes árabes, indianos, africanos e coreanos. Esta área tem sofrido um processo de mudanças e renovação dos espaços, os projetos atuam principalmente em obras de saneamento, novo calçamento das ruas, drenagem e maior divulgação do bairro, buscando sua identidade multicultural (Projeto Ai Mouraria).

\footnotetext{
189 O turismo de Lisboa foi contemplado com alguns prêmios do World Travel Awards de 2014 como melhor destino para cruzeiros na Europa segundo o site http://www.publituris.pt/2014/08/03/portugal-ganha-16-oscaresdo-turismo-europeu/ e o melhor destino City Break do mundo em 2013 de acordo com http://www.visitlisboa.com/Conteudos/Not/2013/09/Lisboa-e-nomeada-para-Melhor-Destino-City-Break-do.aspx
} 


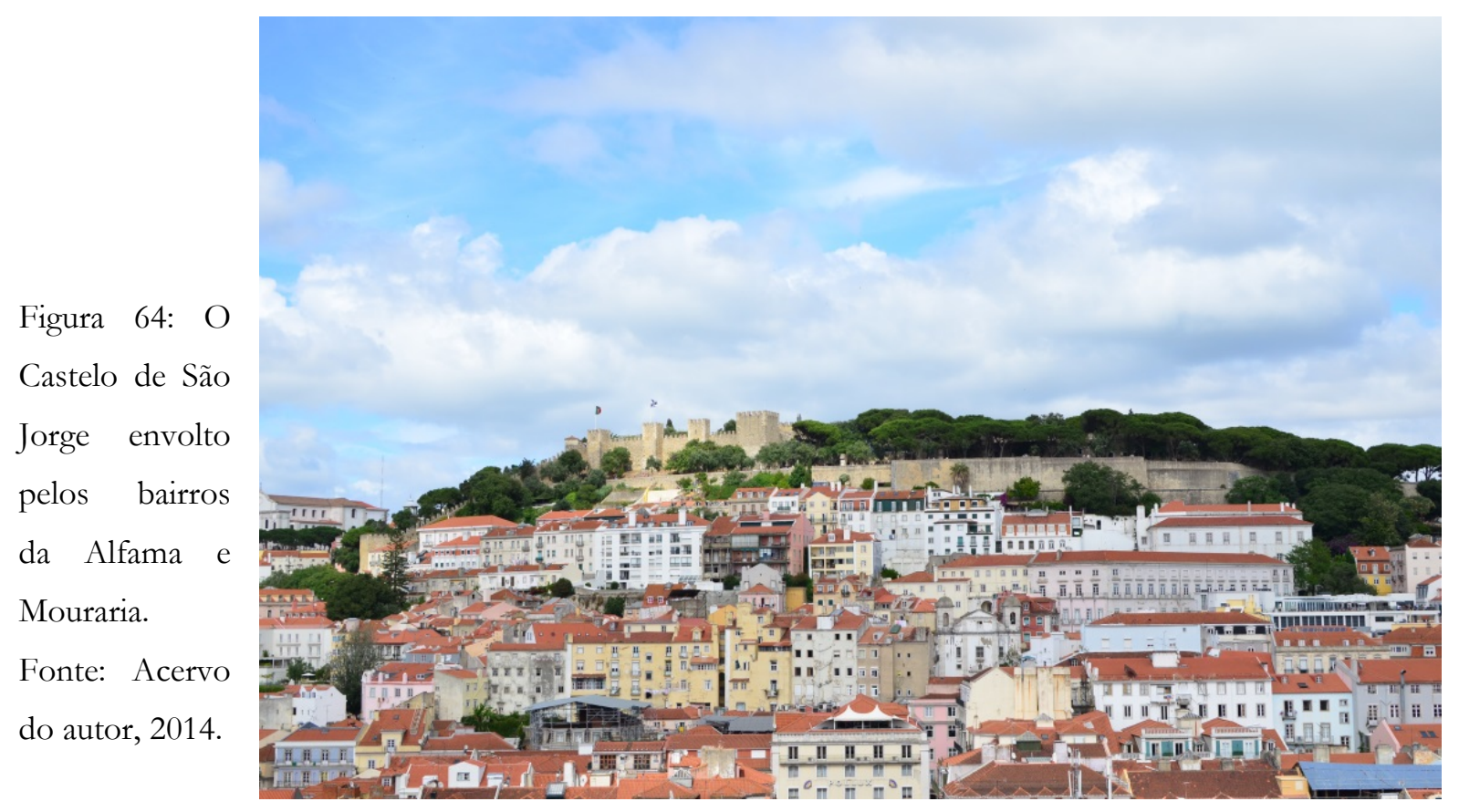

O porto de Lisboa é outro elemento de extrema importância na cidade, pois acompanha seu desenvolvimento sendo parte intrínseca de sua história. Os imensos espaços produzidos pelos aterros, que marcaram a paisagem lisboeta em fins do século XIX, foram resultado das obras do engenheiro francês Henry Hersent (1827-1903), atualmente os aterros são em alguma parte utilizados e em outra ociosa. O porto ainda continua em atividade às margens do rio Tejo, concentrada principalmente em Alcântara, nas proximidades da ponte 25 de Abril, outra grande parte das atividades foi para áreas mais próximas do Atlântico. São os efeitos das mudanças no transporte de mercadorias, que se alterou não apenas no Porto de Lisboa, mas também nos portos por todo o planeta. Estas mudanças estão principalmente na utilização de contêineres que tornaram mais ágeis o embarque e desembarque de mercadorias e otimizaram os espaços, deixando, lamentavelmente ao abandono, os antigos telheiros e barracões. De acordo com Lisa Diedrich (2013, p. 83):

As transformações dos portos têm sido consideradas uma tarefa de planeamento urbano, especialmente desde os anos 1980, quando a nova tecnologia de transporte de carga em contentores fez com que muitas autoridades portuárias deslocassem os seus negócios para fora da cidade, deixando para trás vastas áreas devolutas, desoladas e hostis, sem uso. 


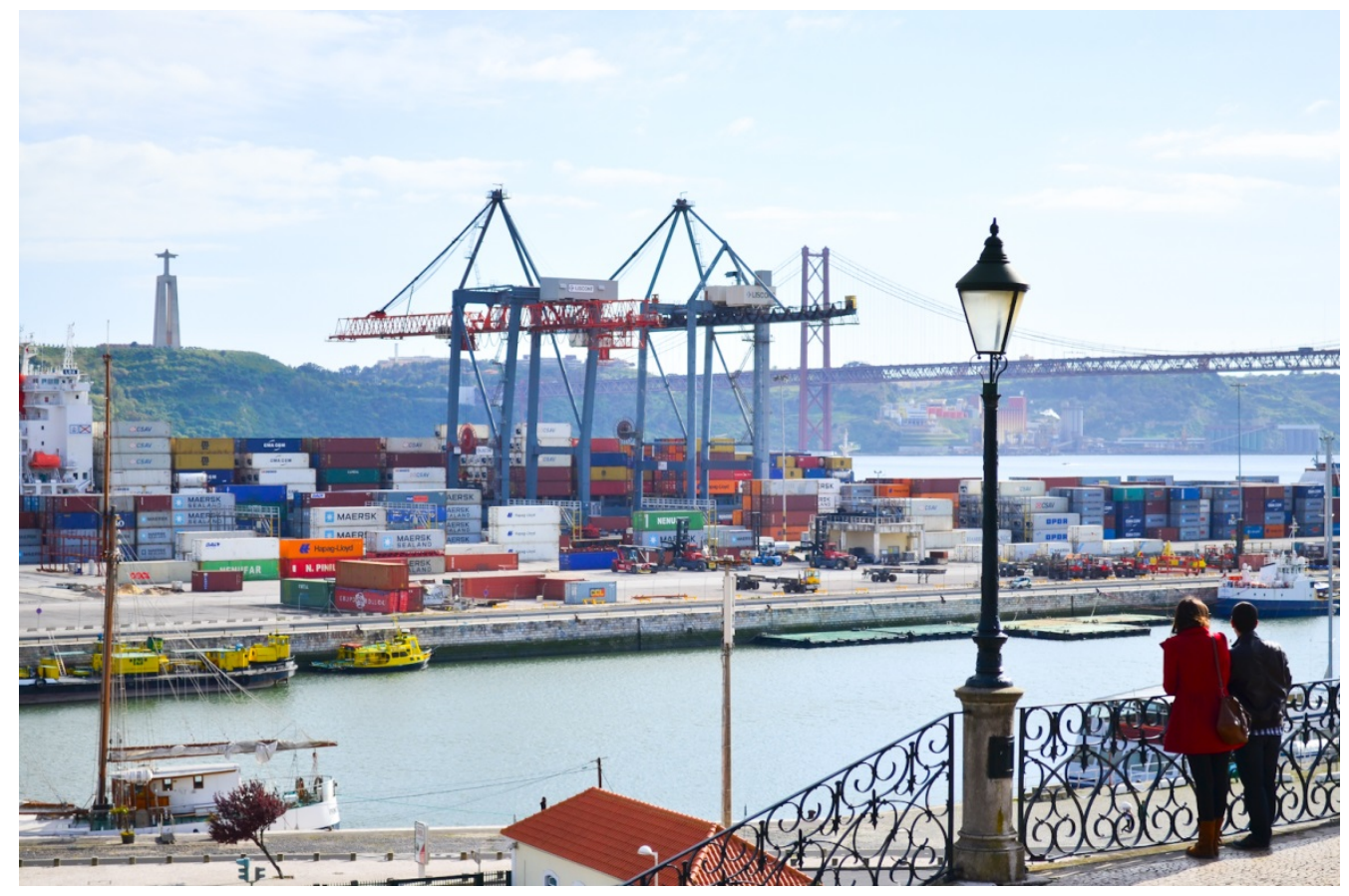

Figura 65: As atividades portuárias em Alcântara, nas proximidades do Museu Nacional de Arte Antiga. Fonte: Acervo do autor, 2014.

Houve também a necessidade de retirar parte das atividades do contexto urbano, para, principalmente, facilitar o transporte terrestre. Mas então surge a questão: como requalificar estes grandes espaços agora sem uso em Lisboa? Uma delas seguiu a tendência da renovação urbana aos moldes de Barcelona a partir de um evento internacional, a Exposição Mundial de 1998 (Figura 66).

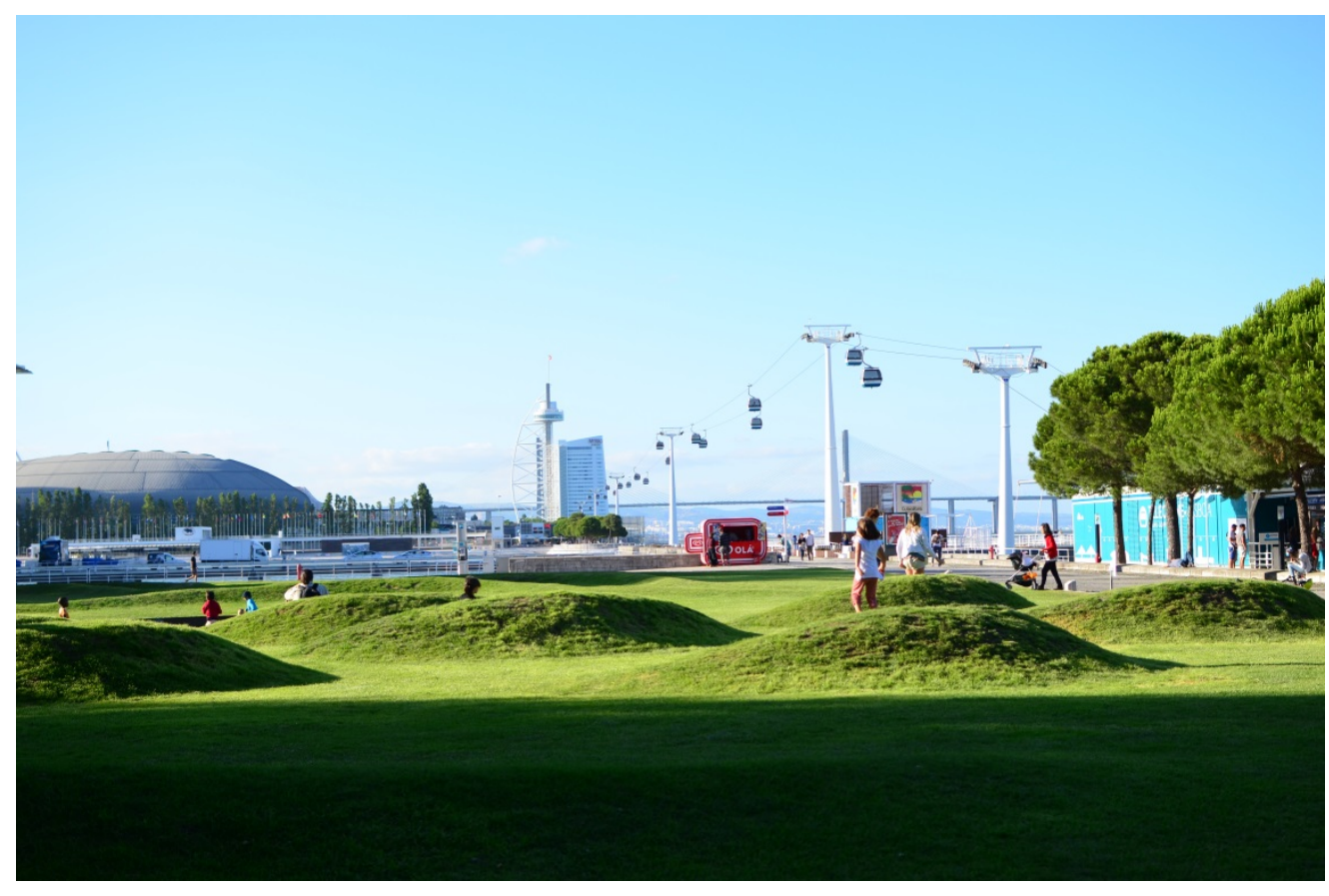

Figura 66: A

Zona da Expo

98. Fonte:

Acervo do autor, 2014. 
Lisboa foi marcada pelas obras de renovação com a Expo 1998. Naquele momento, a cidade possuía sérios problemas urbanísticos, ela perdeu $300 \mathrm{mil}$ habitantes em 30 anos, havia uma população em risco de exclusão, grande número de imóveis devolutos, poucos espaços verdes, falta de qualidade nos espaços públicos e grande dependência do transporte individual. (MASBOUNGI, 2013)

Além disso, surgem questões sobre os projetos para a Expo 98: Permaneceram referências às antigas atividades portuárias naquele espaço? A reconversão apagou os registros que caracterizavam o local? Compreende-se que os espaços construídos detêm características que definem seus usos, sejam eles de trabalho, lazer, contemplação.

$\mathrm{Na}$ zona da Expo 98, as intervenções foram bem sucedidas no que se refere aos novos usos: implantaram-se habitações, comércio, negócios, museu e parques que potencializaram a área antes degradada, são visíveis alguns elementos característicos dos usos antigos, como rampas, muros de contenção etc, mas não há informações ou atividades culturais relacionadas à memória do lugar.

Há outro projeto de renovação urbana que também envolveu a área portuária sobre o Tejo. Situa-se na porção oeste de Lisboa e compreende desde a Ribeira das Naus até a Torre de Belém, contabilizando, aproximadamente, 10 quilômetros de extensão (Figura 67). A maior parte deste trecho portuário foi construída no século XIX com algumas expansões durante o século XX, e abrangem aterros, docas, docas secas, cais avançado, armazéns, gruas etc.

Nestes aterros foi criada uma ciclovia, que na maior parte do percurso, situase à margem do Tejo. Os armazéns são utilizados para casas de show, bares, restaurantes e lojas, como por exemplo, na área da Doca de Santo Amaro em que pequenos armazéns foram transformados em bares e restaurantes, e a doca de recreio mantém seu uso para a parada de pequenas embarcações. 


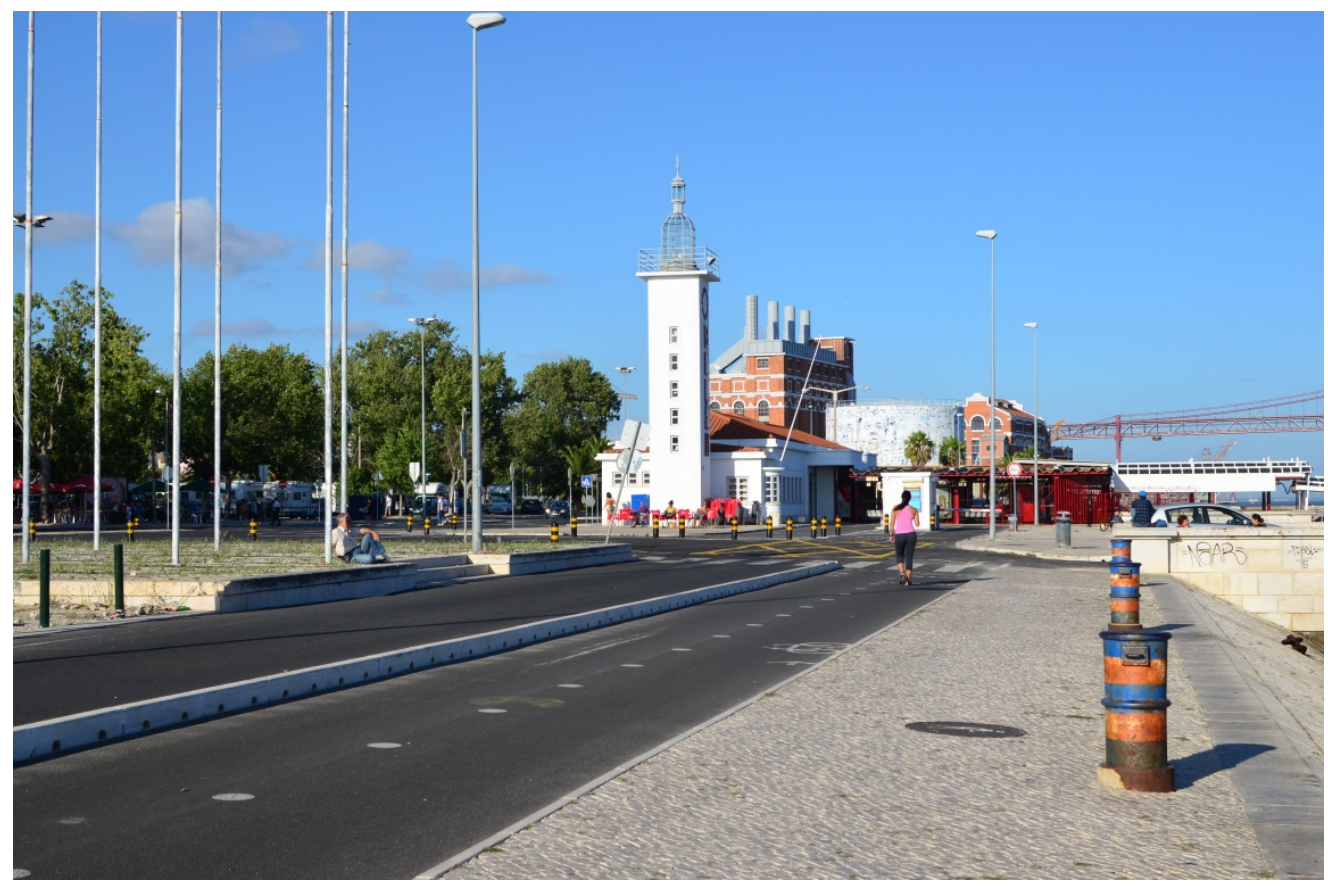

Figura 67: A ciclovia nas proximidades do Museu da Eletricidade. Fonte: Acervo do autor, 2014

Ao longo do porto é possível observar outros armazéns utilizados para atividades de lazer, também existem novos edifícios como o centro de Convenções na rua da Junqueira, o hotel Atlantis e mais recentemente a construção do novo Museu dos Coches (projeto de Paulo Mendes da Rocha). Mas, um dos itens que mais ganham destaque e que percebemos que mais contribui para a compreensão dos antigos usos e na percepção dos espaços é a própria ciclovia (Figura 68).

O percurso permite ter uma dimensão do Porto de Lisboa, observando em diferentes estágios a construção, o funcionamento, sua decadência e os novos usos, perceber que uma área tão importante para o desenvolvimento e história da cidade tem e mantem registros de suas atividades. Ainda funcionam algumas seções das atividades portuárias, concentradas em Alcântara que é o terminal de contêineres que também recebe os grandes navios de cruzeiros e na Rocha do Conde de Óbidos com a manutenção de barcos e navios, em que se encontram as docas secas, infelizmente protegidas com grades, um aparato de segurança, são espaços de trabalho e que necessitam de controle, mas não seria possível, por exemplo, criar maneiras que permitam a melhor visibilidade destes espaços sem que isso afete o cotidiano do trabalho portuário? 
Figura 68: A ciclovia e os cabeços na região próxima ao Cais do Sodré. Fonte: Acervo do autor, 2014.

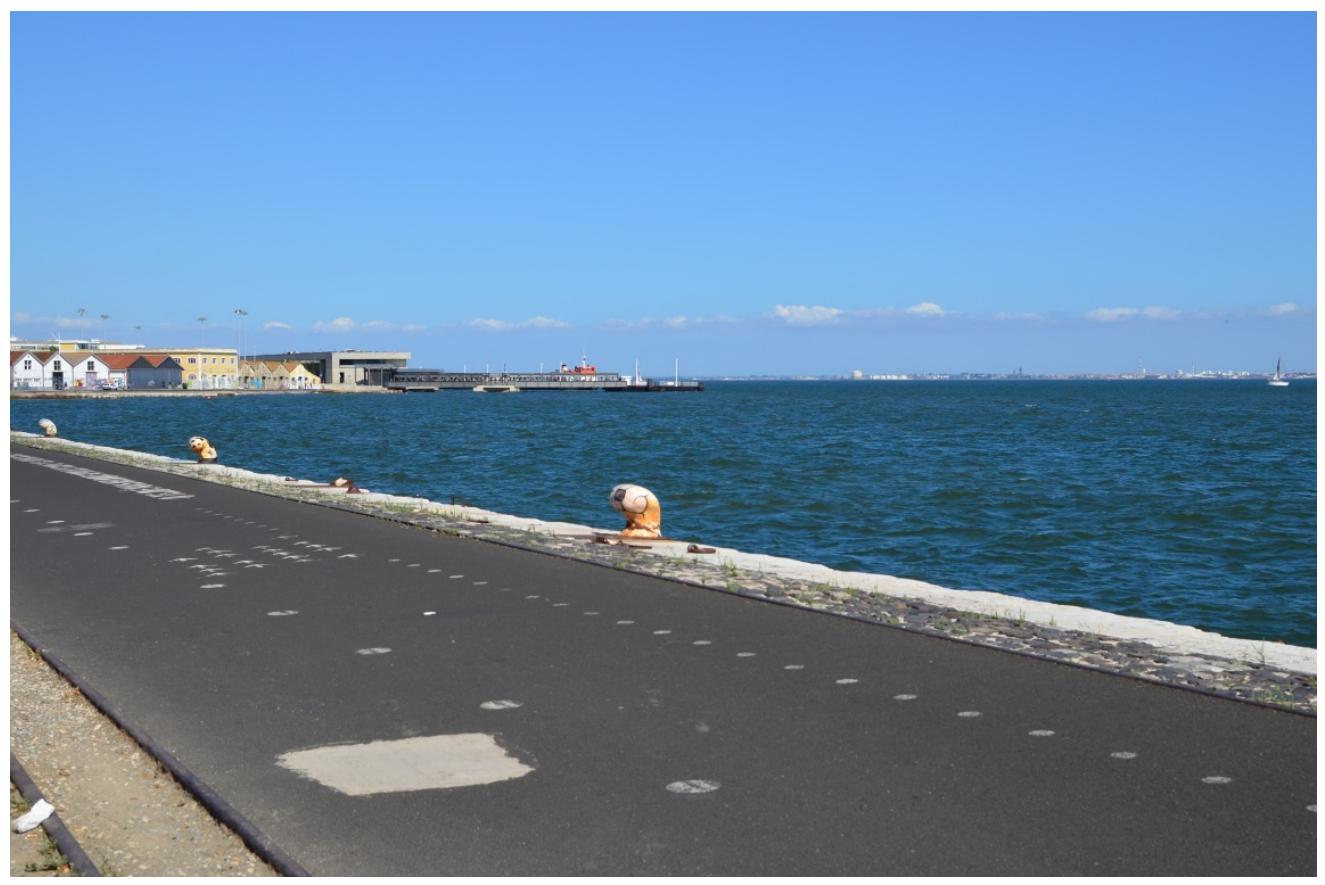

Outros registros são percebidos através de elementos que compõem esta paisagem, revestimentos do antigo porto, partes dos trilhos das gruas que transportavam as mercadorias para as embarcações, as argolas e os cabeços que existem principalmente no trecho do Cais do Sodré até a Rocha do Conde de Óbidos. As docas continuam em uso por pequenas embarcações e também são disponibilizados passeios de barco pelo Tejo. São atividades que estabelecem o contato do rio com a cidade pelas pessoas, sejam elas moradores ou turistas e isto é uma maneira de compreender os processos de transformação da cidade e de estabelecer usos dos espaços (Figura 69).

Os parques ao longo do Tejo são outro item importante nesta relação, são encontrados em alguns trechos, como defronte ao edifício da Cordoaria, nas proximidades do Padrão do Descobrimento, na Torre de Belém e o mais recente na Ribeira das Naus. O último vale uma breve análise, a Ribeira das Naus está localizada muito próxima de um ponto importante para Lisboa, a Praça do Comércio, o parque está implantado à margem do Tejo a partir da restauração das antigas docas secas que possuem uma importância histórica para o país, espaço de manutenção e construção de caravelas, invenção portuguesa que permitiu navegar a 
longas distâncias e que desencadeou a ocupação de diversos territórios e o domínio comercial de muitas rotas mercantes ainda na primeira metade do século XV.

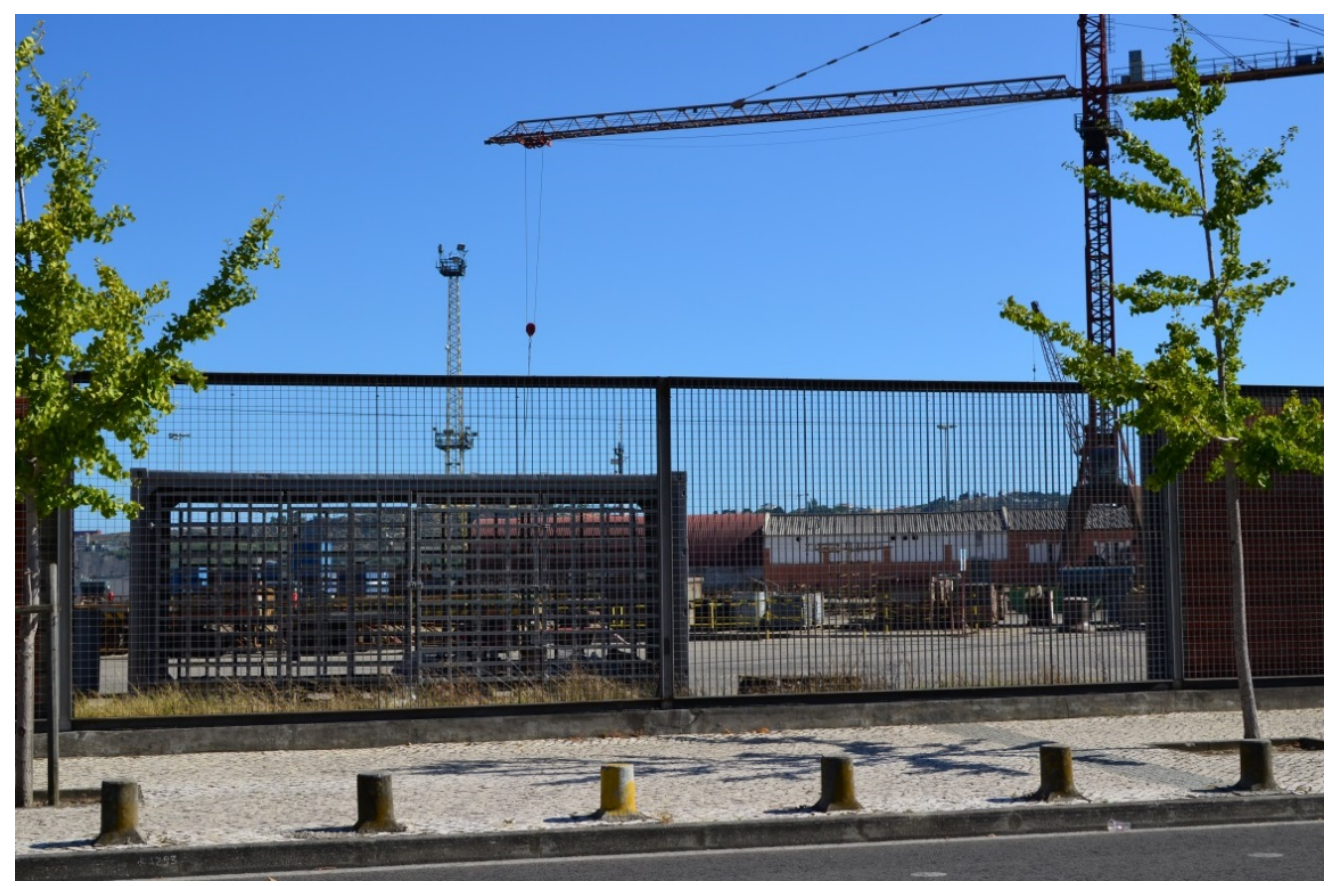

Figura 69: As atividades portuárias visíveis no percurso da ciclovia. Fonte: Acervo do autor, 2014.

O projeto visa a reabilitação do espaço a partir da construção de plataformas juntas ao Tejo que funcionam como uma espécie de praia, aproximando as pessoas do rio, assim como a construção de duas grandes estruturas prismáticas inclinadas contendo um plano gramado em que é possível permanecer e ter uma visão privilegiada do rio. São situações que apontam não só na renovação de espaços em desuso, mas revelam sua história e destacam características: o Tejo torna-se elemento essencial desta renovação. A paisagem construída a partir das relações entre homem e espaço, relações que Jean-Marc Besse (2013) define como perceptivas, afetivas, imaginárias, cognitivas e práticas, permitem leituras distintas de um mesmo sítio, pois "[...] a diversidade das paisagens corresponde a uma outra diversidade, que é a diversidade das maneiras de habitar o mundo." (BESSE, 2013, p. 45) 
Figura 70: As plataformas à beira do Tejo na Ribeira das Naus. Fonte: Acervo do autor, 2014.

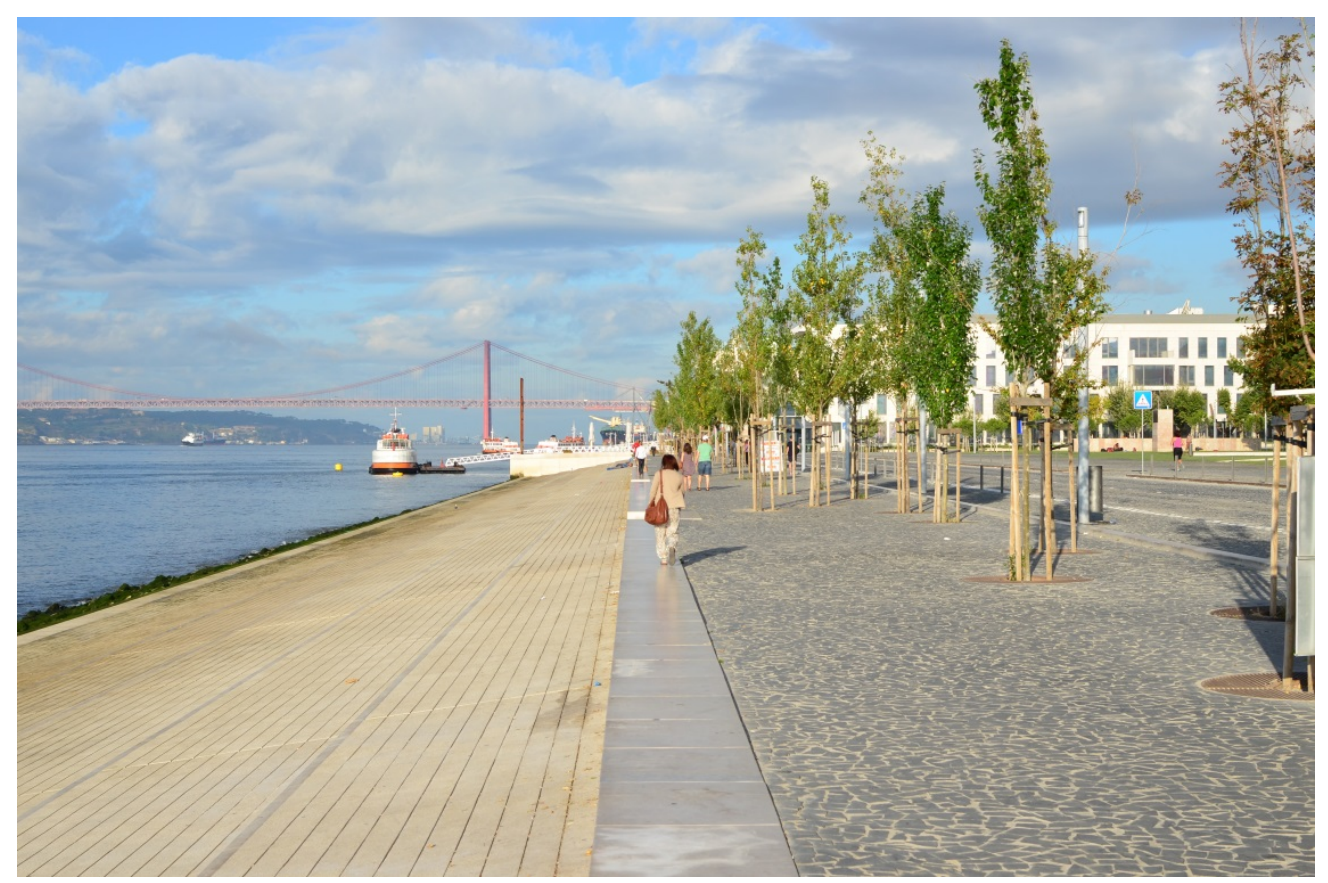

Mas Jean-Marc Besse (2010) define cinco principais orientações que caracterizam a paisagem, uma de representação cultural, dada pela leitura do espaço ou uma sucessão de leituras; a segunda dita culturalista é definida por uma maneira de habitar o mundo, buscando a morada e a identidade, a transformação do território a partir da organização dos espaços; outra ligada ao conceito de sistema paisagístico em que a paisagem é uma realidade material que se reflete a partir de articulações de forças naturais que independem de percepções e representações sociais, o produto histórico do encontro do homem com a natureza; a quarta definição corresponde à fenomenologia em que a paisagem é colocada como eventos de uma experiência mediada pelos sentidos; a última orientação coloca a paisagem como projeto, ela está em transformação a partir de forças naturais, econômicas e sociais que orientam as características e exprimem a partir das formas a paisagem. Para o autor a paisagem é compreendida a partir do conjunto destas transformações:

Il est évident que tout paysage réel, ettoute reencontre réelle avec um paysage, correspondente en fait à um composé de ces cinq orientations. Tout paysage peutêtre considéré à la fois, quoique de manière complexe, comme une réalité matérielle traversée par desvaleurs et des représentations culturelles, comme um milieu de vie, comme le support 
d'une expérience de la sensibilité, et comm eun site appelant des transformations. (BESSE, 2010, p.264)

Quanto às técnicas construtivas, de que maneira elas podem ser inseridas nas questões de patrimônio e paisagem? No porto de Lisboa, as técnicas foram essenciais para que os aterros fossem definidos àquela maneira. A cidade que se expande sobre as águas só foi possível existir pelo uso da tecnologia disponível à época. A história do porto de Lisboa é também a história da tecnologia. Foi a adoção de técnicas mais avançadas, o uso do ar comprimido, a construção de dragas especiais, os avanços no campo da engenharia e a experiência construtiva em outros projetos portuários, que permitiu ao engenheiro francês Henry Hersent a construção dos inúmeros aterros que alteraram drasticamente o perfil da zona ribeirinha. Mas não é apenas isso, a possibilidade de conhecer e identificar de que maneira foi construído o porto, permite analisar como estas tecnologias podem ter se propagado ou não em outras obras na cidade. O ar-comprimido foi a tecnologia amplamente difundida, a partir da metade do século XIX, em diversos países e foi utilizado em grandes obras como a torre Eiffel, o porto da Antuérpia e túneis do metrô sobre o Sena em Paris. Há também a necessidade de conhecer a técnica possibilitando intervir no espaço. Conhecer o modo de construção dos muros dos aterros permite estabelecer critérios para novas intervenções.

A maneira como o porto foi utilizado durante as décadas também tem participação nesse entendimento, a evolução dos transportes e cargas, afetou drasticamente o uso das áreas portuárias, ocasionando o abandono e a decadência:

“[...] o uso de contentores pelas empresas de transportes e a consequente orientação logística das companhias portuárias produziram, em vagas sucessivas, vastas áreas portuárias voltadas ao abandono. Cada transformação provocou uma nova remessa de construções e de áreas, que foi necessário reutilizar poucas décadas depois de entrarem em uso, numa dimensão que torna plausível falar de rejuvenescimento do patrimônio." (DIEDRICH, 2013, p. 88-89). 
Isto também é parte integrante da história portuária, seu uso, abandono e renovação. Espaços que contribuíram economicamente para a cidade devem agora contribuir para sua população através do contato das pessoas com as águas e com este agente transformador que também é paisagem: o porto e suas estruturas, sejam armazéns, cais, docas, gruas, galpões e etc. Estes espaços de trabalho não podem ser lembrados apenas por suas estruturas, quem foram os trabalhadores do porto? Quantas memórias estão relacionadas com as atividades portuárias? Para muitos foi o campo de trabalho, seu cotidiano, para outros um espaço de passagem, são diferentes maneiras de percepção de um mesmo espaço. São múltiplas as possibilidades de compreensão, assim como são múltiplas as percepções. $\mathrm{O}$ que se faz necessária é a maneira como tratar este patrimônio que aos poucos vem ganhando importância nas discussões. Mesmo a Comissão Internacional para a conservação do Patrimônio Industrial não faz recomendações particulares às estruturas portuárias, aconselhando apenas novos usos para sua conservação. (DIEDRICH, 2013). O porto e a sua diversidade de estruturas podem ser analisadas como rugosidades ${ }^{190}$, algo que acaba permanecendo como forma, desencadeada pelo processo social que deixou marcas no espaço, marcas estas que no caso do porto são representativas de uma tecnologia e de uma representação do trabalho.

Trazendo a discussão para nosso objeto de pesquisa, constatamos que existem inúmeras alternativas que permitem o uso e a conservação de estruturas portuárias, mas de que maneira estas alternativas podem ser discutidas para a cidade de Paranaguá? Paranaguá, assim como Lisboa tem uma relação muito próxima com o porto. Mas quanto aos aspectos negativos, os impactos das atividades são maiores na cidade brasileira do que na cidade Lisboeta. Primeiro porque todas as atividades ainda estão concentradas na cidade, na baía de Paranaguá, há um intenso

\footnotetext{
${ }^{190}$ Chamemos rugosidade ao que fica do passado como forma, espaço construído, paisagem, o que resta do processo de supressão, acumulação, superposição, com que as coisas se substituem e acumulam e todos os lugares. As rugosidades se apresentam como formas isoladas ou como arranjos. É dessa forma que elas são uma parte desse espaço-fator. Ainda que sem tradução imediata, as rugosidades nos trazem os restos de divisões do trabalho já passadas (todas as escalas da divisão do trabalho), os restos dos tipos de capital utilizados e suas combinações técnicas e sociais com o trabalho. (SANTOS, 2009, p.140)
} 
movimento de caminhões que causam sérios problemas de mobilidade e poluição, isso se deve aos investimentos no transporte rodoviário em detrimento das linhas férreas. Quanto ao antigo porto localizado no rio Itiberê, existe a necessidade de revelá-lo, pois isto não está claro, primeiro pelos aterros produzidos que afastaram o rio da cidade, resultante do assoreamento do Itiberê, como fica visível defronte ao antigo Colégio dos Jesuítas, hoje uma grande praça com espaços vazios, algumas fontes e um palco para eventos, e também pela falta de qualidade no tratamento das vias e da área ribeirinha, seja no calçamento, nos arruamentos e na construção irregular de trapiches.

Portanto, surgem outros questionamentos que se entrelaçam com as atividades do Iphan e o tombamento de Paranaguá. De que maneira o porto é tratado pelas instituições de preservação e pelo tombamento do setor histórico? Iniciamos a busca por respostas a partir do documento oficial que permitiu a classificação de Paranaguá como cidade histórica, a Instrução do Processo de Tombamento do Centro Histórico de Paranaguá:

Desta forma, ao longo de toda a história da cidade, o porto pode ser considerado o grande responsável pelas dinâmicas econômicas e populacionais de Paranaguá, e desde o início esta é a principal função da cidade, determinante em sua configuração urbana e no caráter populacional até os dias de hoje. (FOGASSA, 2007, p.85).

Figura 71:

Trecho às margens do rio Itiberê, em Paranaguá. Fonte: Acervo do autor, 2012.

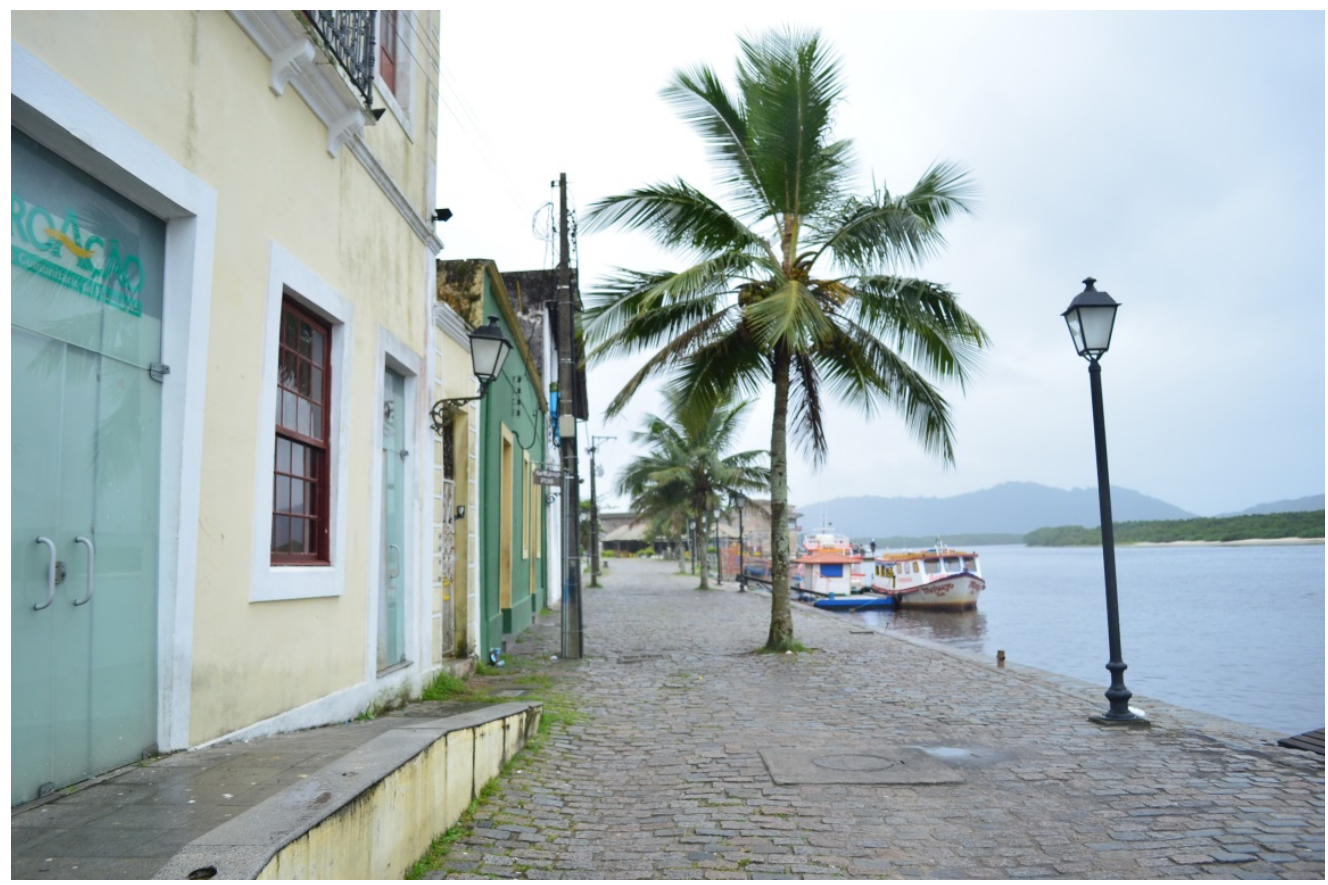


Isto já direciona para outra questão: Se há grande importância do porto para a história da cidade, como foi afirmado na instrução do processo de tombamento, de que maneira são propostas ações para preservação daquilo que ainda resta e que permita revelar as antigas atividades portuárias?

Mas para desenvolver estas questões é necessário compreender a transformação do porto parnanguara. As atividades portuárias, estabelecidas nas margens do Itiberê desde o século XVII, foram transferidas no final do século XIX para a região da baía de Paranaguá, local que permitia a entrada de navios maiores e a ampliação da área portuária. Essas atividades serão realizadas em conjunto com uma das mais importantes obras de engenharia no século XIX no Brasil - a estrada de ferro Paranaguá-Curitiba, que permitiu a ligação entre a área litorânea e o interior do Estado, separados pelo imenso conjunto de escarpas da Serra do Mar.

Entretanto, a transferência do porto para a região da baía não encerrou as atividades na região do rio Itiberê. Ao contrário, continuou muito presente nesta área da cidade, a agitação de embarcações e do comércio Isso é visível nas antigas fotografias da área ribeirinha(entre o final do século XIX e os primeiros decênios do século $\mathrm{XX}$ ) mostrando as embarcações, o comércio lindeiro e a movimentação de cargas. Portanto, as áreas ribeirinhas de Lisboa e Paranaguá configuraram-se por muito tempo como espaços de trabalho, porto, pesca, indústria e comércio. No Brasil, de maneira geral, estes espaços configurados pelo trabalho não são prioridade nas atividades de preservação do patrimônio A desvalorização dos espaços de trabalho na preservação é analisada por Ulpiano Bezerra de Menezes (2007, p. 38): “Compreende-se (embora não se justifique) a desvalorização do trabalho, associada a um alto padrão de desperdício, numa sociedade que ainda tem muito o que fazer para superar sua herança escravocrata."

Assim, estes espaços do trabalho, resultantes do processo de configuração e caracterização da paisagem portuária, determinam usos passíveis de desaparecerem. Estes espaços são dotados de características diversificadas e expressadas através de 
variados elementos, texturas, materiais, cores, que se mantidos e revelados podem trazer à tona um novo olhar sobre o patrimônio, respeitando a memória local e possibilitando a relação identitária com os moradores e antigos trabalhadores. São posturas que poderiam ser consideradas no caso de tanto na área litorânea do Itiberê, mas também do "novo" porto na Baía de Paranaguá, de maneira a trazer não só recursos para o turismo e para as atividades de lazer, mas principalmente fornecer referências aos moradores, muitos deles trabalhadores e ex-trabalhadores do porto, são memórias que revelam modos de vida e trabalho na cidade histórica marítima e fluvial, espaço que se revela a partir de suas manifestações. 

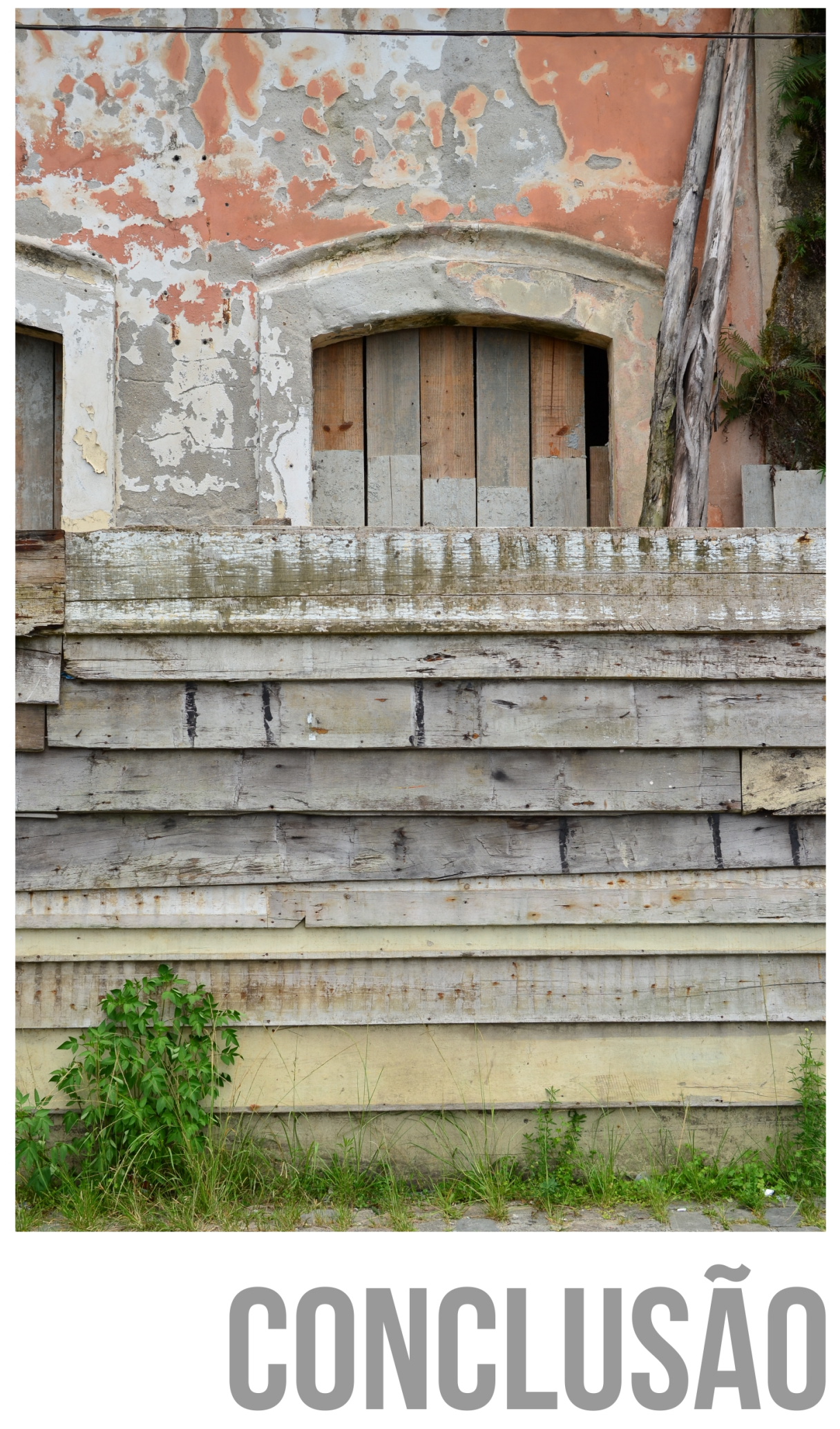



\section{CONCLUSÃo}

Cidade colonial, portuária, litorânea, berço da civilização paranaense, primeira cidade do Paraná, conforme já dissemos estas são algumas das alcunhas dadas à Paranaguá. Cidade que, em sua trajetória, possui marcas do passado do Ciclo do Ouro, da Erva Mate, do Café, representados na arquitetura, no traçado urbano e na paisagem.

Paranaguá, a duras penas, esteve envolvida com as políticas de preservação nacional desde a fundação do IPHAN, com o primeiro tombamento em 1938, que teve forte contribuição da originária rede de contatos estabelecida pelo então diretor Rodrigo Melo Franco de Andrade. Rede que teve importância nas políticas de preservação e contribuiu imensamente para que a cidade estivesse inserida no processo de reconhecimento de seu patrimônio.

É impossível desassociar as atividades de proteção do patrimônio em Paranaguá sem relacioná-las com as figuras-chave, personalidades que participaram intensamente nas atividades de tombamento e restauração da cidade. Estiveram envolvidos localmente e nacionalmente: Rodrigo Melo Franco de Andrade, David Carneiro, Renato Soeiro, Paulo Thedim Barreto, Luís Saia, Augusto da Silva Telles, José Loureiro Fernandes, Cyro Corrêa Lyra, Dalena Guimarães Alves, José La Pastina e Rosina Parchen.

Essa rede iniciada por David Carneiro ganhou força com José Loureiro Fernandes que trocou uma infinidade de cartas com os técnicos do IPHAN, principalmente com Rodrigo Melo Franco, durante a restauração do Colégio dos Jesuítas. E mesmo que não se envolvesse diretamente em outros casos, como os das igrejas de São Benedito e da Ordem Terceira, Loureiro Fernandes teve papel essencial nesses primeiros movimentos.

Notamos por nossas análises que oficialmente a Prefeitura Municipal de Paranaguá adentrou nas políticas de proteção de seu patrimônio a partir do evento 
festivo do Tricentenário de fundação da cidade em 1948. Foi neste momento que se estreitaram as relações entre os representantes locais e o IPHAN, entre as figuras-chave do Paraná, de São Paulo e do Rio de Janeiro.

A restauração empreendida no Colégio dos Jesuítas é um exemplo claro destes sólidos contatos estabelecidos, que em certos momentos foi extremamente conflituoso. Apesar da subordinação do Paraná à São Paulo na administração do IPHAN, a rede de relações estabelecidas com o Rio de Janeiro tornou-se mais intensa do que aquela com a representação paulista, conforme constatamos em nossas análises. Percebemos que a Direção paulista não esboçava muito interesse nas solicitações paranaenses. Os pedidos não só de José Loureiro Fernandes, mas de envolvidos no Governo do Estado do Paraná como Dalena Guimarães Alves, foram ignorados por Luís Saia, por alguma razão que desconhecemos. Isso se repetiu posteriormente com Antônio Luiz Dias de Andrade, no caso da sede do Escritório Técnico, no que indica ter sido uma clara falta de iniciativa dos representantes paulistas, onde mais uma vez a rede de relações estabelecida com o Rio de Janeiro permitiu a concretização da proposta. Mas o que motivaria esta atitude dos técnicos de São Paulo? Apenas desinteresse? Ou receio frente à efetiva atuação do técnico paranaense La Pastina nos trabalhos empreendidos no Paraná? Ou o receio seria da estreita relação que os representantes paranaenses possuíam com a Central Carioca?

Avaliando as atitudes dos técnicos da Direção paulista, vemos o quanto foram prejudiciais ao patrimônio paranaense. Soluções que poderiam ser resolvidas de maneira mais rápida, ficavam sobre a mesa dos técnicos paulistas, muitas vezes sem respostas, afinal solucionadas com a intercessão da Direção Central.

A centralidade da administração de Rodrigo Melo Franco de Andrade, apesar de todas as dificuldades, demonstrou que conseguiu cumprir com a demanda de solicitações advindas de outras regiões do país, pelo menos o que notamos no caso de Paranaguá, principalmente quando os representantes locais possuíam bons trâmites com a Central. 
Dessa forma, a rede de relações permitiu que Paranaguá estivesse inserida no rol de cidades avaliadas pela equipe da UNESCO, quando do acordo de cooperação internacional firmado com o IPHAN. Devemos destacar que não houve o envolvimento da Direção paulistana nesse processo, e vale destacar ainda que nenhuma cidade paulista estava nesta lista. Em contrapartida, neste momento o Estado do Paraná demonstrou forte interesse frente à preservação do centro histórico de Paranaguá, que redundou no estudo do arquiteto belga LimburgStirum e no desenvolvimento do Plano Diretor de Paranaguá em 1968.

Outra revelação valiosa na dinâmica das atividades do IPHAN na cidade ocorre quando nos debruçamos sobre os documentos relativos às restaurações de monumentos. Vemos duas fases distintas de experimentações, a primeira, nos primeiros anos da instituição, quando o Paraná ainda não possuía nenhum técnico disponível e havia a demanda em restaurar o Colégio dos Jesuítas, já tombado. O envolvimento direto de uma figura-chave que não era arquiteto, mas que possuía conhecimentos sobre o tema, José Loureiro Fernandes, foi essencial na concretização deste restauro, marcado por altos e baixos, troca de técnicos responsáveis pela obra, problemas na execução, nos orçamentos e na instalação do museu. Novamente vemos que a resolução dos problemas era originária do Rio de Janeiro, houve pouco envolvimento de técnicos de São Paulo, apenas uma breve participação de Luís Saia no agenciamento da entrada principal do museu.

Durante as análises da documentação sobre o Colégio dos Jesuítas, várias questões nos inquietavam como quais critérios foram primordiais para os procedimentos adotados e se havia algum aporte teórico. Soluções como a alteração de vãos da fachada voltada para a Rua da Praia, a colocação de grades nas janelas, a substituição de vergas de granito por concreto aparente com características distintas das existentes, a retirada da platibanda do anexo localizado na rua XV de Novembro, a proibição de uma placa de indicação do Museu, a falta de registros dos levantamentos e das restaurações, são claras demonstrações de uma falta de coerência na tomada de decisão. Algumas das justificativas são por 
questões de uso, outras relativas à manutenção da imagem do edifício, mas em nenhuma delas vemos a explicitação de um argumento baseado nas teorias em voga. Constatamos que são muito mais procedimentos adotados a partir de uma experiência, que tendo êxito, foram propagadas para outros monumentos. Alguns deles até poderíamos afirmar que têm por base a Carta de Atenas, embora nada sobre isso tenha sido explicitado, bem poderiam ser por questões de minimizar custos, ou ainda pela facilidade do material disponível.

Outro aspecto que mereceu discussão refere-se às propostas que Saia sugeriu para o Colégio dos Jesuítas, extremamente destoantes. A primeira sugestão pouco alterava a edificação no estado em que se encontrava; na segunda proposta, mais radical, sugeriu a demolição de parte da fachada do edifício jesuíta; por último, defendeu a manutenção arqueológica das ruínas da antiga igreja dos Jesuítas. Estas propostas nos fizeram refletir sobre a fase de experimentação, de novas práticas, do objetivo-fim: a imagem do monumento, de sua tradição e também de sua antiguidade, argumentos recorrentes nos documentos dos técnicos da Fase Heroica.

A segunda fase nas atividades de restauração em Paranaguá refere-se ao papel de Cyro Corrêa Lyra, outra figura-chave de extrema importância. Apesar de seu forte envolvimento com o IPHAN, ele nunca chegou a ser técnico da instituição, poderíamos dizer que graças ao período de estágio, mesmo sem vínculo empregatício efetivo, permitiu que posteriormente ele fosse o primeiro arquiteto com especialidade na área atuando em Paranaguá. Conseguimos demonstrar que Cyro carrega as influências dos trabalhos dos principais técnicos do IPHAN, Augusto da Silva Telles e Luís Saia. Sua atuação em Paranaguá foi marcante, sendo responsável pelo restauro das igrejas de São Benedito e da Ordem e da elaboração do Plano Diretor de Paranaguá. Os restauros sob sua responsabilidade utilizaram de métodos já consagrados pelos técnicos do IPHAN, principalmente no uso do cimento, seja nas estruturas em concreto armado que substituíam peças de madeira, seja na consolidação das estruturas de pedra, ou na recomposição de revestimentos. 
Analisando os relatórios de obras e as cartas que discutem as intervenções nas igrejas percebemos que muitas das soluções se baseavam em modelos de outras obras de restauro empreendidas pelos técnicos do IPHAN. Neste momento lembramo-nos do discurso de Lucio Costa sobre o restauro "perfeito" e do texto de Luís Saia.

Lembramos também da solução adotada por Cyro na substituição dos altares colaterais da igreja de São Benedito, por peanhas em concreto, ocultadas pela tinta branca, que tem a linguagem de seu tempo, algo que provavelmente foi um risco, pois não foi procedimento comum no IPHAN, no entanto avalizado pelos técnicos: seria uma abertura a novas possibilidades de postura para a restauração? Afinal foi neste momento que a Carta de Veneza estava sendo divulgada na Instituição, apesar das resistências verificadas na Direção paulista.

No caso da igreja da Ordem, seu restauro também se utilizou de modelos. Cyro propôs o retorno ao uso litúrgico, para isso instalou o altar colateral do século XVIII ao invés, por exemplo, de um altar em linguagem contemporânea aos moldes das peanhas adotada de São Benedito. Enquanto nos altares colaterais da Ordem, estes também não foram recuperados, nem se utilizou de outro recurso para substituí-los. Procedimentos distintos para situações semelhantes, ou seja, o uso de modelos e a experimentação mais uma vez marcando as restaurações em Paranaguá.

Finalmente, em nossas análises quanto ao centro histórico, percebemos que foi necessário possível associá-las aos três primeiros monumentos isolados tombados pelo IPHAN: o Colégio dos Jesuítas, a Igreja da Ordem e a Igreja de São Benedito. A partir das preocupações dos técnicos com a ambiência que se tornaram fortes elementos na delimitação da poligonal, seja na delimitação de Cyro em 1968 que se baseava na proposta de Limburg-Stirum, seja na delimitação de 1991 promovida pelo tombamento estadual, seja na delimitação em 2009 que elevou Paranaguá à categoria de patrimônio histórico nacional, sempre lembrando da influência das figuras-chave, que contribuíram para que esta delimitação tivesse 
estas características. Quanto ao último tombamento, o federal, a questão da paisagem, ensejada pelos representantes paranaenses não obteve êxito, infelizmente a relação entre o porto e a cidade não ficou devidamente explicitada, e o porto, que deveria ser considerado como elemento essencial dessa paisagem de trabalho e de história, foi esquecido.

Percebemos nesta trajetória da proteção do patrimônio parnanguara que, apesar dos entraves e conflitos identificados, principalmente na instância com os representantes paulistas, a cidade esteve envolvida desde o início nas atividades de preservação nacional. Sem dúvida, a relação afinada entre as figuras-chave do Paraná e do Rio de Janeiro foi decisiva no desenvolvimento desta aproximação, permitindo a solução de problemas e a integração, mais recentemente, a partir das mudanças políticas, o patrimônio de Paranaguá ao conjunto de bens tombados no Brasil. 


\section{CARTAS, RelatóRIOS, Ofícios, PARECERES e ATAS.}

Ata da $17^{\mathrm{a}}$ Reunião do Conselho Consultivo do Patrimônio Histórico e Artístico Nacional de 10 de fevereiro de 1953. (Arquivo Central)

Ata da $40^{\text {a }}$ Reunião do Conselho Consultivo do Patrimônio Histórico e Artístico Nacional de 23 de outubro de 1962. (Arquivo Central)

Ata da 52 Reunião do Conselho Consultivo do Patrimônio Histórico e Artístico Nacional de 02 de setembro de 1969. (Arquivo Central)

Ata da reunião realizada na Gerência de Proteção/DEPAM em Brasília nos dias 18 e 19 de março. (Arquivo Central)

Ata da sessão ordinária da Câmara Municipal de Paranaguá de 07/08/1936. (Acervo Câmara Municipal de Paranaguá).

Ata da sessão ordinária da Câmara Municipal de Paranaguá de 06/11/1951. (Acervo Câmara Municipal de Paranaguá).

Boletim Mensal de Informações nº4 de novembro de 1950. (Arquivo Central)

Carta ao Diretor Antônio Luiz Dias de Andrade de 13 de outubro de 1983. (Arquivo Central)

Carta da empresa Merlin, Irmão e Ribas a Carlos Eugênio Contim em 1 de junho de 1953. (Arquivo Central)

Carta da Gerente de Proteção Jurema Kopke Eis Arnaut ao Superintendente José La Pastina em 26/09/2006 (Acervo IPHAN-PR).

Carta da historiadora Márcia Chuva à Coordenadora de Proteção em 22 de maio de 1987. (IPHAN-PR)

Carta de Alfredo Rusins a José Loureiro Fernandes em 18 de junho de 1959. (Arquivo Central)

Carta de Antonio Luis Dias de Andrade ao Prefeito de Paranaguá José Vicente Elias em 27 de julho de 1981. (Arquivo IPHAN-SP).

Carta de Armando Rebollo ao prefeito de Paranaguá José Vicente Elias em 27 de fevereiro de 1978. (Arquivo IPHAN-SP).

Carta de Augusto da Silva Telles a Rodrigo Melo Franco de Andrade em 8 de dezembro de 1965. (Arquivo Central) 
Carta de Carlos Contin a Renato Soeiro em 21 e 22 de novembro de 1953. (Arquivo Central)

Carta de Carlos Contin a Rodrigo Melo Franco de Andrade em 16 de julho de 1952 (Arquivo Central).

Carta de Carlos Contin a Rodrigo Melo Franco de Andrade em 16 de março de 1954. (Arquivo Central)

Carta de Carlos Contin a Rodrigo Melo Franco em 13 de agosto de 1950. (Arquivo Central)

Carta de Cyro Correa Lyra ao Chefe substituto do Distrito do IPHAN em São Paulo de 23 de fevereiro de 1978 (Arquivo IPHAN-SP)

Carta de Cyro Correia Lyra a Luís Saia em 5 de julho de 1973. (Arquivo IPHAN$\mathrm{SP})$

Carta de Dalena Guimarães Alves a Luís Saia de 17 de janeiro de 1966. (Arquivo IPHAN-PR)

Carta de Dalena Guimarães Alves a Renato Soeiro de 07 de dezembro de 1965. (Arquivo Central)

Carta de David Carneiro a Rodrigo Melo Franco de Andrade em 8 de abril de 1937. (Arquivo IPHAN-PR).

Carta de Ennio Marques Ferreira a Luís Saia em 3 de fevereiro de 1962 (Arquivo IPHAN-SP)

Carta de Ennio Marques Ferreira a Rodrigo Melo Franco de Andrade em 24 de março de 1962 (Arquivo Central)

Carta de Guido Arzua a Renato Soeiro em 6 de novembro de 1956. (Arquivo Central).

Carta de João Eugênio Cominese de 15 de maio de 1948. (Acervo do IHGP)

Carta de João Eugênio Cominesi a Rodrigo Melo Franco de Andrade em 6 de dezembro de 1951. (Arquivo Central)

Carta de José La Pastina respondendo as solicitações do prefeito José Vicente Elias de 2 de março de 1990. (Arquivo da Curadoria do Patrimônio Cultural do Paraná).

Carta de José Loureiro a Renato Soeiro em 8 de outubro de 1958. (Arquivo Central) 
Carta de José Loureiro a Rodrigo Melo Franco em 27 de agosto de 1959. (Arquivo Central)

Carta de José Loureiro Fernandes a Rodrigo Melo Franco de Andrade em 12 de abril de 1960. (Arquivo Central)

Carta de José Loureiro Fernandes a Rodrigo Melo Franco de Andrade em 17 de dezembro de 1960. (Arquivo Central)

Carta de José Loureiro Fernandes a Rodrigo Melo Franco de Andrade em 9 de dezembro de 1957. (Arquivo Central)

Carta de José Loureiro Fernandes a Rodrigo Melo Franco de Andrade em 16 de novembro de 1956. (Arquivo Central).

Carta de José Loureiro Fernandes a Rodrigo Melo Franco de Andrade em 26 de maio de 1959. (Arquivo Central)

Carta de José Loureiro Fernandes a Rodrigo Melo Franco de Andrade em 9 de dezembro de 1957. (Arquivo Central)

Carta de José Loureiro Fernandes a Rodrigo Melo Franco de Andrade em 15 de setembro de 1958. (Arquivo Central)

Carta de José Loureiro Fernandes à Rodrigo Melo Franco em 14 de janeiro de 1958. (Arquivo Central)

Carta de José Loureiro Fernandes a Rodrigo Melo Franco em 16 de novembro de 1956. (Arquivo Central)

Carta de José Loureiro Fernandes a Rodrigo Melo Franco em 17 de dezembro de 1960. (Arquivo Central).

Carta de José Loureiro Fernandes a Rodrigo Melo Franco em 27 de outubro de 1960. (Arquivo Central).

Carta de José Loureiro Fernandes a Rodrigo Melo Franco em 5 de fevereiro de 1954. (Arquivo Central)

Carta de José Saia Neto à direção da 9a Regional em 10 de agosto de 1982. (Arquivo IPHAN-SP)

Carta de Julio Moreira ao governador Moisés Lupion em 19 de novembro de 1956. (Arquivo Central)

Carta de Luís Saia a Rodrigo Melo Franco de 16 de junho de 1948. (Arquivo Central) 
Carta de Luís Saia a Rodrigo Melo Franco de Andrade em 9 de maio de 1961. (Arquivo Central).

Carta de Luís Saia a Rodrigo Melo Franco em 27 de abril de 1960. (Arquivo Central).

Carta de Márcia Chuva à Coordenadora de Proteção da SPHAN/FNPM Dora M.S. de Alcântara em 29 de maio de 1987. (Arquivo IPHAN-PR)

Carta de Márcia Chuva, endereçada à coordenadora da SPHAN/FNPM Jurema Kopke em 20 de agosto de 1988. (Arquivo IPHAN-PR).

Carta de Márcia Chuva, endereçada à coordenadora da SPHAN/FNPM Jurema Kopke em 22 de maio de 1987. (Arquivo IPHAN-PR).

Carta de Nelson Buffara a Rodrigo Melo Franco de Andrade em 14 de junho 1956. (Arquivo Central).

Carta de Newton Carneiro a Rodrigo Melo Franco de Andrade em 3 de outubro de 1952. (Arquivo Central)

Carta de Newton Carneiro a Rodrigo Melo Franco em 10 de novembro de 1952. (Arquivo Central)

Carta de Paulo Thedim Barreto Rodrigo Melo Franco de Andrade em 3 de janeiro de 1966. (Arquivo Central)

Carta de Renato Soeiro a Dalena Guimarães Alves em 3 de novembro de 1965. (Arquivo IPHAN-PR)

Carta de Renato Soeiro ao Diretor do Departamento de Cultura do Estado do Paraná Ennio Marques Ferreira em 3 de novembro de 1967 (Arquivo Central).

Carta de Renato Soeiro ao Ministro do Estado de Educação e Cultura Tarso Dutra em 10 de abril de 1968. (Arquivo Central)

Carta de Rodrigo Melo Franco a David Carneiro em 5 de abril de 1937. (Arquivo IPHAN-PR)

Carta de Rodrigo Melo Franco a José Loureiro Fernandes em 23 de julho de 1959. (Arquivo Central)

Carta de Rodrigo Melo Franco a Luís Saia em 13 de novembro de 1959. (Arquivo Central)

Carta de Rodrigo Melo Franco a Oldemar Blasi em 30 de novembro de 1953. (Arquivo Central) 
Carta de Rodrigo Melo Franco de Andrade a Dalena Guimarães Alves em 16 de novembro de 1962. (Arquivo Central)

Carta de Rodrigo Melo Franco de Andrade a Joaquim Tramujas em 14 de janeiro de 1956. (Arquivo Central)

Carta de Rodrigo Melo Franco de Andrade a Joaquim Tramujas em 19 de julho de 1958. (Arquivo Central)

Carta de Rodrigo Melo Franco de Andrade para Joaquim Tramujas em 14 de janeiro de 1956. (Arquivo Central)

Carta do aluno do curso de História da FUNFAFI, Luiz César Rodrigues a José La Pastina em 15 de dezembro de 1989. (Arquivo IPHAN-PR).

Carta do Diretor do DEPROT, Sabino Barroso ao Coordenador da $10^{a}$ CR José La Pastina em 30 de julho de 1993 (Acervo IPHAN-PR).

Carta do Interventor Federal Gen. Div. João da Silva Rebello a Luís Saia em 18 de maio de 1972. (Arquivo IPHAN-SP)

Carta do prefeito José Vicente Elias a Curadora do Patrimônio Histórico e Artístico do Paraná, Rosina Coeli Parchen em 29 de novembro de 1990. (Arquivo da Curadoria do Patrimônio Cultural do Paraná).

Carta do prefeito Waldyr Salmon ao presidente do Pró-memória, Oswaldo José de Campos Melo em 12 de janeiro de 1988. (Arquivo IPHAN-PR)

Carta do Presidente da Câmara Municipal de Paranaguá a Luís Saia de 16 de março de 1971. (Arquivo IPHAN-SP)

Carta enviada pela Chefe da Divisão do Patrimônio Histórico do Paraná, Dalena Guimarães Alves ao então Diretor do $4^{\circ}$ Distrito do IPHAN, Luís Saia em 17 de janeiro de 1963. (Arquivo Central)

Carta enviada pela Chefe da Divisão do Patrimônio Histórico e Artístico do Paraná, Dalena Guimarães Alves ao então Diretor do $4^{\circ}$ Distrito do IPHAN, Luís Saia em 17 de janeiro de 1966. (Arquivo Central)

Carta interna de Paulo Thedim Barreto sobre as dúvidas de Carlos Contim de 26 de março de 1951. (Arquivo Central)

Cartas de Rodrigo Melo Franco a João Eugênio Cominesi em 3 de abril e 4 de junho de 1952. (Arquivo Central) 
Convênio entre a Reitoria da Universidade do Paraná e a Diretoria do Patrimônio Histórico e Artístico Nacional, para instalação do Museu de Paranaguá, em 17 de julho de 1958. (Arquivo Central)

Exposição Retrospectiva de Paranaguá - Exposição do Tricentenário - Lista de Assinaturas, 25 de julho de 1948. (Arquivo IHGP)

Inspeção ao Colégio dos Jesuítas por Edgar Jacintho da Silva em 17 de dezembro de 1957. (Arquivo Central)

Levantamento feito em agosto de 1962 da igreja da São Francisco das Chagas de Paranaguá. (Arquivo IPHAN-SP)

Notificação de tombamento de 29 de março de 1938. (Arquivo Central).

Ofício do coordenador do Programa de Cidades Históricas Henrique Oswaldo de Andrade ao representante da $9^{a}$ Regional Antonio Luis Dias de Andrade em 14 de janeiro de 1982. (Arquivo IPHAN-SP)

Ofício do Diretor da $8^{a}$ Regional da Secretaria do Patrimônio Histórico e Artístico Nacional, Antonio Luis Dias de Andrade ao prefeito de Paranaguá José Vicente Elias em 8 de abril de 1981. (Arquivo IPHAN-SP)

Parecer dado em 24 de abril de 1985 por Augusto da Silva Telles relatando sobre as possíveis candidaturas e aconselhando reuniões para se estabelecerem critérios e discutirem as escolhas. (Arquivo Central).

Parecer de Edgar Acosta Diaz em 24/06/1986. (Arquivo Central)

Prestação de contas da Merlin, Irmãos e Ribas em 1 de julho, 31 de agosto e 30 de setembro de 1953 (Arquivo Central)

Processo de Tombamento do Setor Histórico da cidade de Paranaguá por Ruy Correia Feuerschuette em 20 de dezembro de 1990.

Relatório anexado à carta enviada por Ennio Marques Ferreira a Luís Saia em 3 de fevereiro de 1962. (Arquivo IPHAN-SP)

Relatório da Obra de Restauração e Reforma da Ordem $3^{a}$ de São Francisco das Chagas em Paranaguá. Julho de 1966. (Arquivo Central).

Relatório da vistoria feita por Luís Saia no Colégio dos Jesuítas de 20 de julho de 1948. (Arquivo Central).

Relatório das Obras Feitas na Igreja de São Francisco das Chagas, Paranaguá, Paraná, de setembro de 1974. (Arquivo IPHAN-SP) 
Relatório da obra de reforma e restauração da igreja de São Benedito em Paranaguá, de Cyro Correa Lyra em outubro de 1965. (Arquivo IPHAN-PR)

Relatório de Alfredo Rusins de abril de 1959. (Arquivo Central)

Relatório de José de Souza Reis de 31 de maio de 1960. (Arquivo Central)

Relatório de José Saia Neto sobre a igreja da Ordem Terceira de São Francisco das Chagas, realizado em 1 de agosto de 1981. (Arquivo IPHAN-SP)

Relatório de Paulo Thedim Barreto de abril de 1952. (Arquivo Central)

Relatório de Visita à Obra de autoria de José La Pastina em 2 de fevereiro de 1984. (Arquivo IPHAN-SP)

Relatório de vistoria do Colégio dos Jesuítas por Luís Saia em 3 de julho de 1948. (Arquivo Central)

Relatório final apresentado por José La Pastina em 25 de junho de 1984. (Arquivo IPHAN-SP)

Relatório sobre a situação atual da igreja de São Benedito de autoria de Cyro Correa Lyra em 25 de maio de 1965. (Arquivo IPHAN-PR).

Telegrama de Fernando Correia Azevedo a Rodrigo Melo Franco de Andrade em 4 de junho de 1949. (Arquivo Central)

Telegrama de José Loureiro Fernandes a Rodrigo Melo Franco de Andrade em 21 de julho de 1948. (Arquivo Central)

Telegrama de José Loureiro Fernandes a Rodrigo Melo Franco de Andrade em 20 de abril de 1940. (Arquivo Central)

Telegrama do coordenador do Programa de Cidades Históricas Henrique Oswaldo de Andrade ao representante da $9^{a}$ Regional Antonio Luís Dias de Andrade em 15 de junho de 1982.

Telegrama do secretário da Cultura do Ministério da Educação e Cultura, Marcos Vinicius Vilaça, ao representante da $9^{a}$ Regional, Antonio Luís Dias de Andrade, em 4 de outubro de 1982. (Arquivo IPHAN-SP)

Telegramas de Dalena Guimarães Alves a Luís Saia em 23 e 26 de novembro de 1964. (Arquivo IPHAN-SP)

Termo de Compromisso firmado entre a Fundação Nacional Pró-Memória e a Prefeitura Municipal de Paranaguá, em 5 de janeiro de 1984. (Arquivo IPHAN-SP) 


\section{REFERÊNCIAS}

AGUIAR, José. Após Veneza: do restauro estilístico para o restauro crítico. In: Portugal 1910-2010 - 100 anos de património: memória e identidade. $2^{a}$ Ed. Lisboa: IGESPAR, 2011.

ANDRADE, Antonio Luiz Dias de. Estado Completo que Pode Jamais ter Existido. 1992. Tese (Doutorado em Arquitetura e Urbanismo) - Faculdade de Arquitetura e Urbanismo - USP.

ANDRADE, Mario. Mário de Andrade: cartas de trabalho: correspondência com Rodrigo Mello Franco de Andrade (1936-1945). Brasília: Secretaria do Patrimônio Histórico e Artístico Nacional: Fundação Pró-memória, 1981.

ANDRADE, Rodrigo Melo Franco. Rodrigo e o SPHAN: Coletânea de textos sobre o patrimônio cultural. Rio de Janeiro: Ministério da Cultura/Fundação Nacional Pró-Memória, 1987.

BARBACCI, Alfredo. Il gasto dela città antica e del paesaggio. Florença: Felice Le Monnier, 1962.

BESSE, Jean-Marc. Estar na Paisagem, habitar, caminhar. In: CARDOSO, Isabel Lopes (Org.) Paisagem Património. Porto: Chaia - Universidade de Évora, 2013.

BOURDIEU, Pierre. O Poder Simbólico. Lisboa: Bertrand, 1989.

BRANDI, Cesare. Teoria da Restauração. Tradução de KÜHL, Beatriz Mugayar. 2. ed. Cotia: Ateliê Editorial, 2005.

BRASIL. Ministério da Educação e Cultura. Anais do II Encontro de Governadores para preservação do patrimônio histórico, artístico, arqueológico e natural do Brasil, realizado em Salvador, Bahia, de 25 a 29 de outubro de 1971. Rio de Janeiro: Publicações do IPHAN, nº 26, 1973.

BRASIL. Programa Monumenta: Sítios Históricos e conjuntos urbanos de monumentos nacionais: sudeste e sul. Volume II. Brasília: Ministério da Cultura, Programa Monumenta, 2005.

BUGAY, Eliane Regina. Plano de Preservação para o Centro Histórico de Paranaguá: Proposta de Trabalho. Paranaguá, 1989.

CANCLINI, Nestor. O patrimônio cultural e a construção imaginária do nacional. Revista do IPHAN, no 23, 1994, p. 94-115.

CARBONARA, Giovanni. Avvicinamento al restauro: teoria, storia, monumenti. Napoli: Liguori, 2006a.

CARBONARA, Giovanni. Brandi e a Restauração Arquitetônica Hoje. Desígnio, 2006b, no 6, p.35-47. 
CARNEIRO, David D. da Silva. Colégio dos Jesuítas em Paranaguá. Revista do Serviço do Patrimônio Histórico e Artístico Nacional. Rio de Janeiro, no 4, p. 361 382, 1940. Disponível em: www.iphan.gov.br. Acesso em: 03/06/2010.

CARTA DE ATENAS. In: CURY, Isabelle (Org). Cartas Patrimoniais. $2^{a}$ Ed. Rio de Janeiro: IPHAN, 2000.

CARTA DE VENEZA. In: CURY, Isabelle (Org). Cartas Patrimoniais. $2^{a}$ Ed. Rio de Janeiro: IPHAN, 2000.

CARUNCHIO, Tancredi. Dal restauro ala conservazione. Introduzione ai temi della conservazione e del patrimônio architettonico. Roma: Kappa, 1996.

CHOAY, Françoise. A alegoria do patrimônio. São Paulo: Estação Liberdade: Editora UNESP, 2001.

CHUVA, Márcia Regina Romeiro. Chuva 2007

CHUVA, Márcia Regina Romeiro. Os Arquitetos da Memória: sociogênese das práticas de preservação do patrimônio cultural no Brasil (anos 1930-1940). Rio de Janeiro: Editora da UFRJ, 2009.

CIATTI, Marco. Appunti per un manuale di storia e di teoria del restauro: Dispensi per gli studenti. Florença: Edifir, 2009.

CORREIO DA MANHÃ. Restauração de um monumento histórico. Correio da Manhã, 27 de fevereiro de 1946.

COSTA, Everaldo Batista da. Totalidade Urbana e Totalidade-Mundo: As cidades coloniais barrocas face à patrimonialização global. 2011. $444 \mathrm{f}$. Tese (Doutorado em Geografia Humana). Faculdade de Filosofia, Letras e Ciências Humanas - Universidade de São Paulo. 2011.

COSTA, Lucio. Arquitetura Jesuítica no Brasil. Revista do Serviço do Patrimônio Histórico e Artístico Nacional. Rio de Janeiro, no 5, p. 9 - 104, 1941. Disponível em: www.iphan.gov.br. Acesso em: 03/06/2010.

COSTA, Lucio. Muita Construção, alguma arquitetura e um milagre. In: COSTA, Lucio. Lucio Costa: Registro de uma Vivência. São Paulo: Empresa das Artes, 1995.

CUNHA, Claudia dos Reis e. Restauração: diálogos entre teoria e prática no Brasil nas experiências do IPHAN. 171 p. Tese (Doutorado). Área de Concentração: História e Fundamentos da Arquitetura e do Urbanismo. FAUUSP, 2010.

DECRETO-LEI $\mathrm{n}^{\circ}$ 25, de 30 de novembro de 1937. Rio de Janeiro: IPHAN. Disponível em: www.iphan.gov.br Acesso em: 05/07/2010.

DIÁRIO DA TARDE. Será desvendando o mistério do subterrâneo do Colégio dos Jesuítas. Diário da Tarde, 10/07/1939. 
DIÁRIO DO PARANÁ. Ney inaugura transmissão do Marumbi e duas salas do Museu de Paranaguá. Diário do Paraná, 30 de julho de 1971.

DIÁRIO OFICIAL DA UNIÃO. Portaria n¹27 de 30 de abril de 2009: estabelece a Chancela da Paisagem Cultural Brasileira. Diário Oficial da União, 5 de maio de 2009.

DIEDRICH, Lisa. Entre a tábula rasa e a museificação - Abordagens específicas para projectos de transformação de grande escala em cidades portuárias europeias. In: CARDOSO, Isabel Lopes (Org.) Paisagem Património. Porto: Chaia - Universidade de Évora, 2013.

DOURADO, Odete. Antigas falas, novas aparências: o tombamento do Ilê Axé Nassô Oká e a preservação dos bens patrimoniais no Brasil. Risco. São Carlos, no 14, 2011, p. 6-19.

DUDEQUE, Irã José Taborda. Espirais de Madeira: uma história da arquitetura de Curitiba. São Paulo: Studio Nobel: FAPESP, 2001.

FILHO, Anybal Ribeiro. Exposição Retrospectiva no Tricentenário de Paranaguá - 1948. Paranaguá, 1974. Manuscrito.

FONSECA, Maria Cecília Londres. O Patrimônio em Processo: Trajetória da Política Federal de Preservação no Brasil. Rio de Janeiro: UFRJ: IPHAN, 2009.

FOGASSA. H. (2013). Humberto Fogassa: entrevista [março/2013]. Entrevista: JABUR, R. S. Curitiba: Escritório Humberto Fogassa.

FOGASSA, Humberto. Instrução do Processo de Tombamento do Centro Histórico de Paranaguá - Pr. Curitiba, 2007.

FRANÇA. Lei. 62/903, de 4 de agosto de 1962. Complementa a legislação sobre o patrimônio histórico e estético da França. Acesso em: 07/05/2013. Disponível em: http://www.malraux.org/images/documents/loimalraux.pdf.

FRANCO DE ANDRADE, Rodrigo Melo. Rodrigo e seus tempos. Rio de Janeiro: Fundação Nacional Pró-Memória, 1986.

FURTADO, Maria Regina. José Loureiro Fernandes: O Paranaense dos Museus. Curitiba: Imprensa Oficial, 2006.

GAZETA DO POVO. Paranaguá, berço da civilização paranaense. Gazeta do Povo, 30/07/1948.

GONÇALVES, Cristiane Souza. Restauração Arquitetônica: A Experiência do SPHAN em São Paulo, 1973-1975. São Paulo: Annablume; Fapesp, 2007.

GONÇALVES, José Reginaldo Santos. A retórica da perda: os discursos do patrimônio cultural no Brasil. Rio de Janeiro: Editora UFRJ, 1996.

JELIDI, Charlotte. La fabrication d'une ville nouvelle sous le Protectorat français au Maroc (1912-1956): Fès-nouvelle. Tese (Doutorado em História), Université François Rabelais - Tours, 2007. 
JUNIOR, Romeu Duarte. Programa Monumenta: uma experiência em preservação urbana no Brasil. Revista CPC, n.10 p.44-88, maio/outubro 2010 São Paulo

KERSTEN, Márcia Scholz de Andrade. Os Rituais do Tombamento e a Escrita da História: Bens Tombados no Paraná entre 1938-1990. Curitiba: Editora da UFPR, 2000.

KÜHL, Beatriz Mugayar. Arquitetura do Ferro e Arquitetura Ferroviária em São Paulo - Reflexões sobre a sua Preservação. São Paulo: Ateliê Editorial: Fapesp: Secretaria da Cultura, 1998.

KÜHL, Beatriz Mugayar. Notas sobre a Carta de Veneza. Anais do Museu Paulista. São Paulo, v.18, n.2, p. 237-320, 2010.

KÜHL, Beatriz Mugayar. Preservação do Patrimônio Arquitetônico da Industrialização: problemas teóricos de restauro. São Paulo: Ateliê Editorial, 2013.

LA PASTINA. J (2012). José La Pastina: entrevista [março/2013]. Entrevista: JABUR, R. S. Curitiba: Superintendência do IPHAN.

LEAL, Claudia Feierabend. A missão de Michel Parent no Brasil. In: As Missoes da Unesco no Brasil: Michel Parent. LEAL, Claudia Feierabend (Org.). Rio de Janeiro: IPHAN, COPEDOC, 2008.

LIMA, Francisca Helena Barbosa; MELHEM, Mônica Muniz e POPE, Zulmira Canário. (Org.). Bens Móveis e Imóveis Inscritos nos Livros do Tombo do Instituto do Patrimônio Histórico e Artístico Nacional 1939-2009. $5^{a} E d$. Rio de Janeiro: IPHAN/COPEDOC, 2009.

LONDRES, Maria Cecilia. Referências Culturais: Base para novas políticas do patrimônio. In: Inventário Nacional de Referências Culturais: Manual de Aplicação. Brasília: IPHAN, 2000.

LYRA. C. I.C (2012). Cyro Illidio Correa Lyra: entrevista [agosto/2012]. Entrevista: JABUR, R. S. Rio de Janeiro: Residência do entrevistado.

LYRA. Cyro Illídio Correa. Restauração da igreja de São Benedito da cidade de Paranaguá. Revista Arquitetura, Rio de Janeiro, nº 72-73, junho-julho de 1968, p. 14-18.

MAACK, Reinhard. Geografia Física do Estado do Paraná. Curitiba: Banco do Desenvolvimento do Estado do Paraná, 1968.

MASBOUNGI, Ariella (Org.) Le Projet Urbain em Temps de Crise: L'exemple de Lisbonne. Paris: Le Moniteur, 2013.

MATTOS. L. M. B. (2013). Luiz Marcelo Bertoli de Mattos: entrevista [março/2013]. Entrevista: JABUR, R. S. Paranaguá: Prefeitura Municipal de Paranaguá. 
MATTOS, Luiz Marcelo Bertoli. Programa de Recuperação do Centro Histórico de Paranaguá. Paranaguá, 2004. Arquivo digital fornecido pelo autor em abril de 2005.

MAYUMI. Lia. Taipa, canela-preta e concreto: Estudo sobre o restauro de casas bandeiristas. São Paulo: Romano Guerra Editora, 2008.

MENESES, Ulpiano Bezerra de. A Cidade como Bem Cultural - Áreas Envoltórias e outros Dilemas, Equívocos e Alcance na Preservação do Patrimônio Ambiental Urbano. In MORI, Victor Hugo (Org.). Patrimônio: Atualizando o Debate. São Paulo: IPHAN, 2006.

MENESES, Ulpiano Bezerra de. Os Usos Culturais da Cultura. Contribuição para uma abordagem crítica das práticas culturais e políticas culturais. In: YAZIGI, E; CARLOS, A. F. A. 1996.

MICELI, Sergio. SPHAN: Refrigério da Cultura Oficial. Revista do Patrimônio Histórico e Artístico Nacional. Rio de Janeiro, nº 22, p. 44-47, 1987.

MILLET, Vera. A Teimosia das Pedras: Um estudo sobre a preservação do patrimônio ambiental no Brasil. Olinda: Prefeitura de Olinda, 1988

MINISSI, Franco. Conservazione dei Beni Storico Artistici e Ambientali: Restauro e Musealizzazione. Roma: De Luca Editore, 1978.

MOTTA, Lia. A SPHAN em Ouro Preto: Uma história de conceitos e critérios. Revista do IPHAN, nº22, p. 108-122, 1987.

NASCIMENTO, Flávia Brito; SCIFONI, Simone. O Tombamento de Iguape como Patrimônio Nacional: Novas Práticas e Políticas de Preservação. PARC Pesquisa em Arquitetura e Cosntrução, Campinas, v.6, n.1, p.26-38, jan/mar. 2015.

NIGRO, Cíntia. Territórios do Patrimônio: Tombamentos e Mobilizações Sociais. In: CARLOS, Ana Fani Alessandri; LEMOS, Amália Inês Geraiges. (Orgs). Dilemas Urbanos: Novas Abordagens sobre a Cidade. São Paulo: Contexto, 2003. p. 166-177.

NORMA DE QUITO. In: CURY, Isabelle (Org). Cartas Patrimoniais. $2^{a}$ Ed. Rio de Janeiro: IPHAN, 2000.

O ESTADO DO PARANÁ. Paranaguá poderá perder o seu Centro Histórico.

O Estado do Paraná, 20 dez. 1989.

PARANÁ em Páginas. Ano XI, no 125. Curitiba, julho de 1975.

PARANÁ, Livro do Tombo Histórico. Setor Histórico de Paranaguá. Processo n 17/90, inscrição 109. 1990.

PARANÁ, Secretaria de Estado da Cultura. Espirais do Tempo: Bens Tombados do Paraná. Curitiba: Secretaria de Estado da Cultura, 2006. 
PARANÁ. Igreja da Ordem Terceira de São Francisco das Chagas, Paranaguá - Paraná. Curitiba, 1981.

PARANÁ. Lei N¹211: Dispõe sobre o Patrimônio Histórico, Artístico e Natural do Estado do Paraná. Curitiba, 16 de setembro de 1953.

PARANÁ. Plano Diretor de Paranaguá. Paranaguá, 1967.

PARANÁ. Tricentenário do Município de Paranaguá. Curitiba: Álbum Documentário do Paraná, 1948.

PARANAGUÁ poderá perder o seu Centro Histórico. O Estado do Paraná, 20 dez. 1989.

PARANAGUÁ. Lei no 1592 de 28 de fev. de 1990. Altera a redação do inciso IV.

PARANAGUÁ. Lei $\mathbf{n}^{\mathbf{0}} \mathbf{7 7 3 / 6 9}$ de 12 de setembro de 1969. Institui o Plano Diretor de Paranaguá. Pasta Centro Histórico de Paranaguá, Arquivo da Coordenação do Patrimônio Cultural do Paraná.

PARANAGUÁ. Plano Diretor de Paranaguá: edição definitiva. 30 de julho de 1990.

PARANAGUÁ: um porto colonial. Jornal do Brasil, Rio de Janeiro, 31 out. 1974. Turismo, p. 6 e 7.

PARCHEN. R.C. (2013). Rosina Coeli Parchen: entrevista [março/2013]. Entrevista: JABUR, R. S. Curitiba: Coordenação do Patrimônio Cultural.

PARENT, Michel. Proteção e Valorização do Patrimônio Cultural Brasileiro no Âmbito do Desenvolvimento Turístico e Econômico. In: As Missões da Unesco no Brasil: Michel Parent. LEAL, Claudia Feierabend Baeta (Org). Rio de Janeiro: Iphan, COPEDOC, 2008.

PESSÔA, José (Org). Lucio Costa: Documentos de Trabalho. $2^{a}$ Ed. Rio de Janeiro, Iphan, 2004.

PESSOA, José; PICCINATO, Giorgio (Org). Atlas de Centros Históricos do Brasil. Rio de Janeiro: Casa da Palavra, 2007.

PREFEITURA MUNICIPAL DE PARANAGUÁ. Setor de Patrimônio Histórico. Plano Diretor, 1998. Arquivo eletrônico fornecido pelo Arquiteto Luiz Marcelo Bertoli de Mattos em abril de 2005.

PROJETO de lei quer a extinção do centro histórico. Diário do Commercio, 8 de dez. de 1989. Capa.

RABELLO, Sonia. O Estado na preservação de bens culturais: o tombamento. Rio de Janeiro: IPHAN, 2009.

Revista do Patrimônio Histórico e Artístico Nacional. Rio de Janeiro: IPHAN, no18, 1978. 
Revista do Patrimônio Histórico e Artístico Nacional. Rio de Janeiro: IPHAN, n'22, 1987.

ROCHA, Ricardo. José de Souza Reis e o SPHAN: da inconfidência à glória. In: $7^{\circ}$ Seminário DO.CO.MO.MO Brasil - O Moderno já passado/O Passado no moderno: reciclagem, requalificação, rearquitetura, 2007, Porto Alegre. Anais do $7^{\circ}$ Seminário DO.CO.MO.MO Brasil, 2007.

RODRIGUES, Marly. Imagens do Passado: A instituição do patrimônio em São Paulo 1969-1987. São Paulo: Memórias, 1994.

RUBINO, Silvana. O Mapa do Brasil Passado. Revista do Patrimônio Histórico e Artístico Nacional. Rio de Janeiro, no 24, p. 96-105, 1996. Disponível em: www.iphan.gov.br Acesso em: 10/07/2010.

RUFINNONI, Manoela Rossinetti. Preservação e Restauro Urbano: intervenções em sítios históricos industriais. Tese (Doutorado), Área de Concentração: História e Fundamentos da Arquitetura e do Urbanismo, FAUUSP, São Paulo, 2010.

RUSKIN. John. A Lâmpada da Memória. Trad. Maria Lucia Bressan Pinheiro. São Paulo: Ateliê Editorial, 2008.

SAIA, Luís. Até os 35 anos, a Fase Heróica. Revista CJ Arquitetura. Rio de Janeiro, Ano 5, no 17, p. 16-21, 1977.

SANT'ANNA, M. G. A Cidade-Atração: A norma de preservação de centros urbanos no Brasil dos anos 90. Tese (Doutorado em Arquitetura e Urbanismo) Faculdade de Arquitetura, Universidade Federal da Bahia, 2004.

SANT'ANNA, M. G. de. Da cidade-monumento à cidade-documento: a trajetória da norma de preservação de áreas urbanas no Brasil (1937-1990). Dissertação (mestrado) - Faculdade de Arquitetura e Urbanismo, Universidade Federal da Bahia, Salvador, 1995.

SANTOS, Antonio Vieira dos Santos. Memória Histórica de Paranaguá. Vols. I e II, Curitiba: Vicentina, 2001.

SANTOS, Mariza Velloso Motta. Nasce a Academia SPHAN. Revista do Patrimônio Histórico e Artístico Nacional. Rio de Janeiro, no 24, p. 77 - 95. 1996.

SCIFONI, Simone. Parque do Povo: Um patrimônio do futebol de várzea em São Paulo. Anais do Museu Paulista. São Paulo, v.21, julho-dezembro de 2013, p. 125-151.

STIRUM, Frédéric de Limburg. Plan National de mise em valeur de Parati dans le cadre d'un développement touristique. Paris : UNESCO, 1968.

TELLES, Augusto C. da Silva. Atlas dos Monumentos Históricos e Artísticos do Brasil. $2^{\text {a }}$ Ed. Rio de Janeiro: FAE, 1985.

TELLES, Augusto C. da Silva. Centros Históricos: Notas sobre a Política Brasileira de Preservação. IN: Revista do Patrimônio Histórico e Artístico 
Nacional, Rio de Janeiro, $\mathrm{n}^{\circ}$ 19, 1984. Disponível em: www.iphan.gov.br Acesso em: 10/07/2010.

THOMPSON, Analucia. Memórias do Patrimônio: Entrevista com Augusto da Silva Telles. Rio de Janeiro: IPHAN, 2010.

VIOLLET-LE-DUC, Eugène Emmanuel. Restauração. Tradução de KÜHL, Beatriz Mugayar. 4ª Ed. São Paulo: Ateliê Editorial, 2013.

VIOLLET-LE-DUC, Eugène Emmanuel. Dictionnaire Raisonné de 1'Architecture Française du XI au XVI Siécle.. Paris: B. Bance Éditeur, 1854.

XAVIER, Laura Regina. Patrimônio em Prosa e Verso: a Correspondência de Rodrigo Melo Franco de Andrade para Augusto Meyer. 158 p. Dissertação (Mestrado). Programa de Pós-Graduação em História Política e Bens Culturais, Fundação Getúlio Vargas. Rio de Janeiro,2008. 